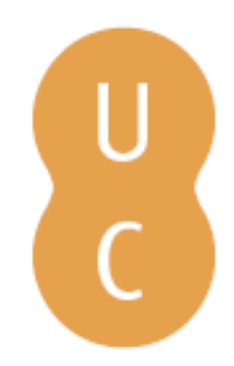

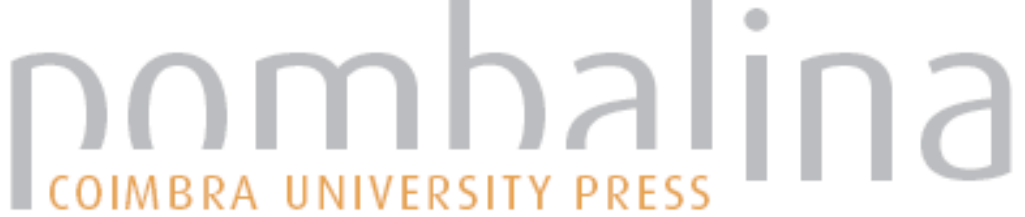

\section{Luciano IV}

Autor(es): $\quad$ Samósata, Luciano de; Magueijo, Custódio, trad.

Publicado por: Imprensa da Universidade de Coimbra

URL

persistente:

URI:http://hdl.handle.net/10316.2/29944

DOI:

DOI:http://dx.doi.org/10.14195/978-989-26-0794-8

Accessed : $\quad$ 26-Apr-2023 14:47:16

A navegação consulta e descarregamento dos títulos inseridos nas Bibliotecas Digitais UC Digitalis, UC Pombalina e UC Impactum, pressupõem a aceitação plena e sem reservas dos Termos e Condições de Uso destas Bibliotecas Digitais, disponíveis em https://digitalis.uc.pt/pt-pt/termos.

Conforme exposto nos referidos Termos e Condições de Uso, o descarregamento de títulos de acesso restrito requer uma licença válida de autorização devendo o utilizador aceder ao(s) documento(s) a partir de um endereço de IP da instituição detentora da supramencionada licença.

Ao utilizador é apenas permitido o descarregamento para uso pessoal, pelo que o emprego do(s) título(s) descarregado(s) para outro fim, designadamente comercial, carece de autorização do respetivo autor ou editor da obra.

Na medida em que todas as obras da UC Digitalis se encontram protegidas pelo Código do Direito de Autor e Direitos Conexos e demais legislação aplicável, toda a cópia, parcial ou total, deste documento, nos casos em que é legalmente admitida, deverá conter ou fazer-se acompanhar por este aviso. 
Colecção Autores Gregos e Latinos SérIe TeXTos

\section{LuCiano de Samósata}

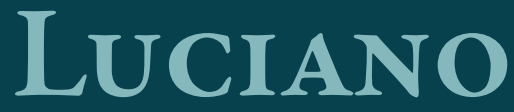

$[\mathrm{IV}]$

TRADUÇÃO DO GREGO, INTRODUÇÃO E NOTAS Custódio Maguejo 
Amadurecido pelas viagens e pela experiência da vida, materialmente afortunado, Luciano cedo se farta da actividade judiciária, da retórica e da sofística, para se entregar a uma actividade literária que, não sendo nova, ele, no entanto, reforma de maneira radical: trata-se do diálogo filosófico, mas agora entendido e elaborado segundo princípios originais. De facto, Luciano aligeira substancialmente o majestoso diálogo filosófico que vinha dos tempos de Platão e acrescenta-lhe um aspecto dramático, orientado no sentido da sátira - o que significa reunir no «novo género» dois géneros diferentes e até muito diversos: o diálogo filosófico e a comédia. Realmente, foram sobretudo as obras em forma de diálogo que deram fama a Luciano. É nelas que melhor se expande a sua crítica panfletária e corrosiva, que atinge, literalmente, tudo e todos: os deuses e os heróis, a religião e as religiōes, a filosofia e as suas variadíssimas seitas, a moral convencional, a sociedade e os seus pilares mais destacados, os homens e as suas vaidades, as suas superstiçóes irracionais e o aproveitamento que delas fazem os espertos... enfim, podemos dizer que em Luciano conflui o que de mais violento havia na comédia. Um certo epicurismo prático e um cinismo teórico afinam e refinam o processo. 
(Página deixada propositadamente em branco) 
(Página deixada propositadamente em branco) 


\title{
Luciano de Samósata
}

\section{Luciano}

\author{
[IV]
}

Tradução do grego, introdução e notas de Custódio Magueijo

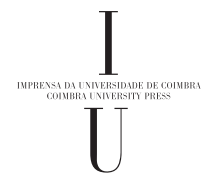




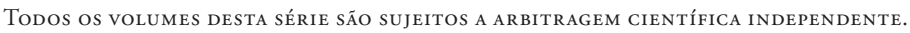

Título $\cdot$ Luciano [IV]

Traduçấo do Grego, Introdução e Notas • Custódio Magueijo

Autor • Luciano de Samósata

\section{Série Monografias}

Coordenador Científico do plano de edição: Maria do Céu Fialho

CoMissão EDTORIAL

José Ribeiro Ferreira

Francisco de Oliveira

Maria de Fátima Silva

Nair Castro Soares

Diretor Técnico: Delfim Leão

\section{Obra REALIZADa No ÂMbito DAS aCtiVidades Da UI\&D Centro de Estudos Clássicos e Humanísticos}

\section{EdiçÃo}

Imprensa da Universidade de Coimbra

URL: http://www.uc.pt/imprensa_uc

E-mail: imprensauc@ci.uc.pt

Vendas online:

http://livrariadaimprensa.uc.pt

CoORdENAÇÁO EDITORIAL

Imprensa da Universidade de Coimbra

CoNCEPÇÃo GRÁFICA

Imprensa da Universidade de Coimbra

INFOGRAFIA

Simóes \& Linhares
Impressä́ e ACABAmento

www.artipol.net

ISBN

978-989-26-0793-1

ISBN DigitaL

978-989-26-0794-8

DOI

http://dx.doi.org/

10.14195/978-989-26-0794-8

Depósito Legal

$353356 / 12$

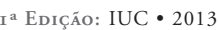

(C) Dezembro 2013.

IMPRENSA DA UNIVERSIDADE DE COIMBRA

Classica Digitalia Vniversitatis Conimbrigensis (http://classicadigitalia.uc.pt)

Centro de Estudos Clássicos e Humanísticos da Universidade de Coimbra

Reservados todos os direitos. Nos termos legais fica expressamente proibida a reproduçáo total ou parcial por qualquer meio, em papel ou em ediçáo electrónica, sem autorizaçáo expressa dos titulares dos direitos. É desde já excepcionada a utilizaçáo em circuitos académicos fechados para apoio a leccionaçáo ou extensáo cultural por via de e-learning. 


\title{
Luciano de Samósata
}

\section{Luciano}

\author{
[IV]
}

Tradução do grego, introdução e notas de Custódio Magueijo

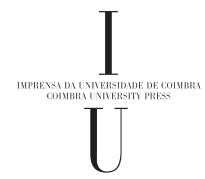


(Página deixada propositadamente em branco) 


\section{SUMÁRIO}

INTRODUÇÃO GERAL

CONTRA OS ASSALARIADOS DOS GRANDES................................ 17

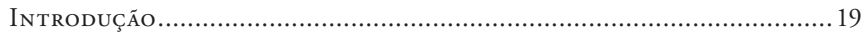

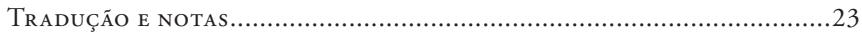

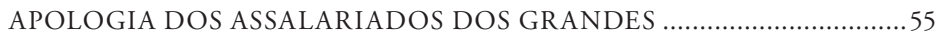

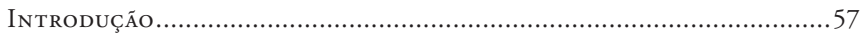



MENIPO OU DESCIDA AOS INFERNOS ........................................... 71

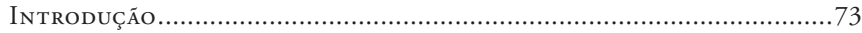

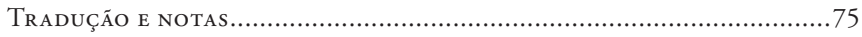

A TRAVESSIA PARA O HADES OU O TIRANO .................................. 91

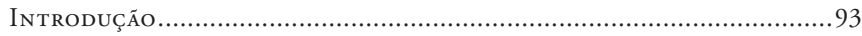

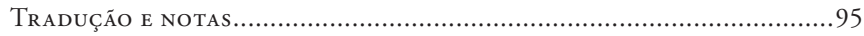

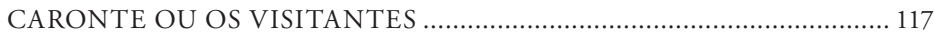

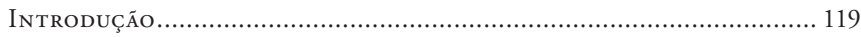

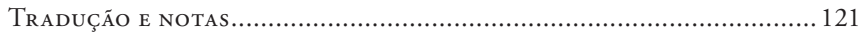

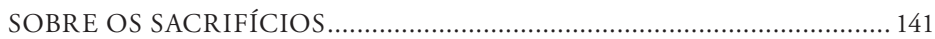

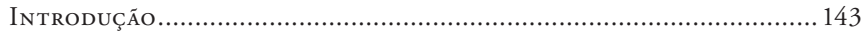

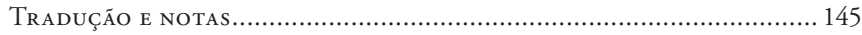

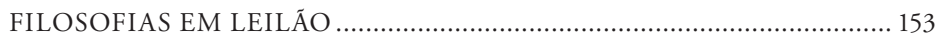



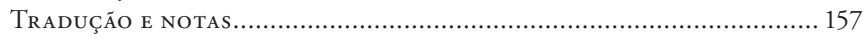

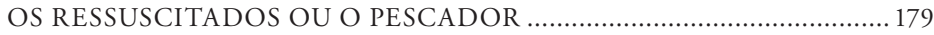

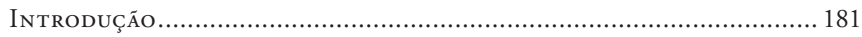

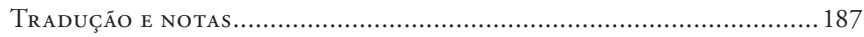


(Página deixada propositadamente em branco) 


\title{
Luciano
}

\author{
[IV]
}

CONTRA OS ASSALARIADOS DOS GRANDES

\author{
APOLOGIA DOS ASSALARIADOS DOS \\ GRANDES
}

MENIPO OU DESCIDA AOS INFERNOS

A TRAVESSIA PARA O HADES OU O TIRANO

CARONTE OU OS VISITANTES

SOBRE OS SACRIFÍCIOS

FILOSOFIAS EM LEILÃO

OS RESSUSCITADOS OU O PESCADOR 
Ficha Técnica:

Autor: Luciano de Samósata

Título: Luciano (IV):

- Contra os Assalariados dos Grandes

- Apologia dos Assalariados dos Grandes

- Menipo ou Descida aos Infernos

- A Travessia para o Hades ou O Tirano

- Caronte ou Os Visitantes

- Sobre os Sacrifícios

- Filosofias em Leilão

- Os Ressuscitados ou O Pescador

Traduçấo, prefácio e notas: Custódio Magueijo

Edição utilizada: A. M. Harmon, Lucian, The Loeb Classical Library: Greek authors, Harvard University Press, 1959-1961. 


\section{INTRODUÇÁO GERAL ${ }^{1}$}

Luciano nasceu em Samósata, capital do antigo reino de Comagena, situado a norte da Síria, na margem direita do Eufrates. Os primeiros imperadores romanos conservaram-lhe um certo grau de independência, mas acaba por ser incluído entre as províncias do Império Romano.

Quanto a datas de nascimento e morte, aceitemos 125-190 d. C. Seguramente, a vida literária de Luciano desenvolve-se na segunda metade do séc. II d. C., por um período de quarenta anos, durante o qual escreveu cerca de oitenta obras.

No tocante a dados biográficos, temos de contentar-nos com as informaçóes contidas no conjunto dos seus escritos. Pelo menos têm a vantagem de serem de primeira máo. E se a nossa curiosidade mais "superficial» gostaria de saber muitas outras coisas sobre a sua vida, a verdade é que o essencial do homem está nítida e magnificamente retratado na obra.

De entre as obras mais importantes do ponto de vista autobiográfico, salienta-se a intitulada $O$ Sonho (ou Vida de Luciano). Imediatamente se conclui tratar-se dum trabalho da meia-idade, que mais abaixo resumimos.

Após uma peregrinação de vários anos por terras da Grécia, da Itália e da Gália, onde conseguira assinalável êxito e náo menos importante pecúlio, Luciano regressa (por volta de 162-163) à sua cidade natal, que o havia visto partir pobre e quase anónimo, e agora se orgulhava do prestígio que lhe era transmitido pelo próprio êxito dum filho seu. E então que Luciano, perante os seus concidadãos, traça uma retrospectiva autobiográfica, da qual mencionamos os passos mais salientes.

Chegado ao termo da escolaridade elementar, adolescente de quinze anos, o pai aconselha-se com familiares e amigos sobre o futuro do moço.

"A maioria opinou que a carreira das letras requeria muito esforço, longo tempo, razoável despesa e uma sorte brilhante. Ora, a nossa fortuna era limitada, pelo que, a breve trecho, precisariamos

${ }^{1}$ Esta «Introdução geral» é, na verdade, reproduzida de outras que escrevi a propósito de diversas obras de Luciano. Não se pode exigir que, para cada uma das cerca de oitenta, tivesse de inventar uma biografia formalmente diferente de Luciano. No entanto, a parte final, relativa a cada obra em particular, é redigida especialmente para esta edição. 
de alguma ajuda. Se, pelo contrário, eu aprendesse um ofício, começaria imediatamente a retirar dai um ordenado minimo, que me permitiria, naquela idade, deixar de ser um encargo familiar, $e$ até mesmo, algum tempo depois, dar satisfação a meu pai com o dinheiro que traria para casa." (\$1)

Restava escolher o ofício. Discutidas as várias opiniōes, foi decidido entregar o rapaz aos cuidados dum tio materno, presente na reunião, e que era um excelente escultor. Além deste factor de ordem familiar, pesou ainda o facto de o moço, nos seus tempos livres, gostar de se entreter a modelar, em cera, bois, cavalos e figuras humanas, "tudo muito bem parecido, na opiniáo de meu pai». Por essa actividade "plástica» (é palavra sua), que não raro o desviava dos deveres escolares, "chegava mesmo a apanhar pancada dos professores, mas isso agora transformava-se em elogio à minha vocação». (\$2)

Chegado o grande dia, é com certa emoção que o jovem Luciano se dirige à oficina do tio, a fim de iniciar a sua nova vida. De resto, via no ofício de escultor uma espécie de brincadeira de certo modo agradável, e até uma forma de se distinguir perante os amigos, quando estes o vissem esculpir figuras de deuses e estatuetas. Todavia, e contrariamente às suas esperanças, o começo foi desastroso. O tio põe-lhe na mão um escopro e manda-o desbastar uma placa de mármore, a fim de adiantar trabalho ("O começar é meio caminho andado»). Ora... uma pancada um pouco mais forte, e eis que se quebra a placa... donde uma monumental sova de correia, que só a fuga consegue interromper. Corre para casa em tal estado, que a mãe não pode deixar de censurar asperamente a brutalidade do irmão. Entretanto, aproxima-se a noite, e o moço, ainda choroso, dolorido e revoltado, foi deitar-se. As fortes emoções do dia tiveram como resultado um sonho - donde o título da obra. (\$\$ 3-4)

Até aqui, Luciano fornece-nos dados objectivos, que nos permitem formar uma ideia suficientemente precisa sobre si próprio e sobre a situação e ambiente familiares. Quanto ao sonho, se nada nos permite duvidar da sua ocorrência, a verdade é que se trata, antes de mais, duma elaboração retórica, elemento tantas vezes utilizado na literatura, mas nem por isso menos significativo do ponto de vista autobiográfico. De facto, Luciano serve-se deste processo para revelar aos seus ouvintes não tanto o que se terá passado nessa noite, mas principalmente 
a volta que a vida dera, a partir duma situação que, em princípio, teria uma sequência bem diferente.

Assim, e com uma nitidez - segundo afirma - "em nada diferente da realidade», aparecem-lhe duas mulheres, que, energicamente e até com grande violência, disputam a posse do moço, que passa duma para a outra, e volta à primeira... enfim, "pouco faltou para que me despedaçassem".

Uma delas era a Escultura (Hermoglyphikê), "com o (tipico) aspecto de operário, viril, de cabeleira sórdida, mãos cheias de calos, manto subido e coberto de pó, como meu tio quando estava a polir as pedras». A outra era a Cultura (Paideia), "de fisionomia extremamente agradável, pose digna e manto traçado a preceito". (\$\$ 5-6).

Seguem-se os discursos de cada uma das personagens, que fazem lembrar o agôn ("luta», "disputa») das Nuvens de Aristófanes, travado entre a Tese Justa e a Tese Injusta.

A fala da Escultura, mais curta (\$\$ 7-8), contém, no entanto, elementos biográficos (explícitos e implícitos) de certa importância. Começa por se referir à tradição profissional da família do jovem, cujo avô materno e dois tios, também maternos, eram escultores de mérito. A seguir, enumera as vantagens da profissão: comida farta, ombros fortes e, sobretudo, uma vida particular ao abrigo de invejas e intrigas, em vez de (como, de resto, veio a suceder - daí também o valor biográfico da informação) viagens por países longínquos, afastado da pátria e dos amigos. De resto, a História está cheia de exemplos de grandes escultores (Fídias, Policlito, Míron, Praxíteles), cujo nome é imortal e que são reverenciados juntamente com as estátuas dos deuses por eles criadas.

O discurso da Cultura ( $\$ \$$ 9-13) possui todos os ingredientes necessários à vitória (além das informações biográficas que recolhemos das suas "profecias»... já realizadas). Vejamos alguns passos.

"Meu filho: eu sou a Cultura, entidade que já te é familiar e conhecida, muito embora ainda não me tenhas experimentado completamente.

"Quanto aos grandes benefícios que te proporcionará o ofício de escultor, já esta aqui os enumerou: náo passarás dum operário que mata o corpo com trabalho e nele depóes toda a esperança da sua vida, votado ao anonimato e ganhando um salário magro e 
vil, de baixo nivel intelectual, socialmente isolado, incapaz de defender os amigos ou de impor respeito aos inimigos, de fazer inveja aos teus concidadãos. Apenas isto: um operário, um de entre a turba, prostrado aos pés dos poderosos, servidor humilde dos bem-falantes, levando uma vida de lebre, presa do mais forte. E mesmo que viesses a ser um outro Fídias ou um Policlito, mesmo que criasses muitas obras-primas, seria apenas a obra de arte aquilo que toda a gente louvaria, e ninguém de bom senso, entre os que a contemplassem, ambicionaria ser como tu. Sim: por muito hábil que sejas, não passarás dum artesão, dum trabalhador manual.

"Se, porém, me deres ouvidos, antes de mais revelar-te-ei as numerosas obras dos antigos, falar-te-ei dos seus feitos admiráveis e dos seus escritos, tornar-te-ei um perito em, por assim dizer, todas as ciências. Equanto ao teu espírito - que é, afinal, o que mais importa -, exorná-lo-ei com as mais variadas e belas virtudes: sabedoria, justiça, piedade, doçura, benevolência, inteligência, fortaleza, amor do Belo e paixão do Sublime. Sim, que tais virtudes é que constituem verdadeiramente as incorruptiveis jóias da alma...

"Tu, agora pobre, tu, o filho do Zé-Ninguém, tu, que ainda há pouco havias enveredado por um ofício tão ignóbil, dentro em breve serás admirado e invejado por toda a gente, cumulado de honrarias e louvores, ilustre por tua alta formação, estimado das elites de sangue e de dinheiro; usarás um traje como este (e apontava-me o seu, que era realmente magnífico) e gozarás de merecido prestígio e distinção. E sempre que saias da tua terra, vás para onde fores, não serás, lá fora, um obscuro desconhecido: impor-te-ei tal marca, que, ao ver-te, um qualquer, dando de cotovelo ao vizinho, apontar-te-á com o dedo, dizendo: "É este, o tal”...”

O final do discurso ( $\$ 13)$ constitui um autêntico "fecho" elaborado segundo as leis da retórica. Depois de, no parágrafo anterior, ter mencionado os exemplos de Demóstenes (filho dum fabricante de armas), de Ésquines (cuja mãe era tocadora de pandeireta) e de Sócrates (filho de escultor), lança o ataque final:

"Caso desprezes o exemplo de tão ilustres homens, seus feitos gloriosos e escritos veneráveis, presença imponente, honra, glória e louvores, supremacia, poder e dignidades, fama literária e o apreço devido à inteligência - então passarás a usar uma túnica reles e encardida, ganharás um aspecto servil, agarrado a alavancas, 
cinzéis, escopros e goivas, completamente inclinado sobre o trabalho, rastejante e rasteiro, humilde em todas as acepçóes da palavra, sem nunca levantar a cabeça, sem um único pensamento digno dum homem livre, mas antes continuamente preocupado com a ideia de a obra te sair harmoniosa e apresentável - enquanto a respeito de ti próprio, da maneira de te tornares harmonioso e bem dotado, não te importas absolutamente nada; pelo contrário, ficarás mais vil que as mesma pedras."

É pena que esta autobiografia não tivesse sido escrita uns vinte (ou trinta) anos mais tarde. Em todo o caso, Luciano, noutras obras, fornece-nos mais algumas indicações.

Assim, pela Dupla Acusação (\$27), escrita pouco depois do Sonho, sabemos que Luciano, entregue de alma e coraçáo à retórica e à sofística, iniciara a sua actividade de advogado em várias cidades da Ásia Menor (Segundo a Suda, "começou por ser advogado em Antioquia»). Da Ásia Menor, passa para a Grécia, e daí para a Itália, mas é sobretudo na Gália que obtém glória e fortuna.

Uma dúzia de anos depois de ter saído da sua terra natal, regressa a casa, mas por pouco tempo. Decide fixar-se com a família em Atenas, onde permanece por cerca de vinte anos (c.165-185 d.C.).

Aos quarenta e poucos anos, Luciano adopta uma atitude fundamentalmente céptica, que, sobretudo, se insurge contra todo o dogmatismo metafísico e filosófico em geral. A este respeito, recomenda-se vivamente a leitura do Hermotimo (ou As Seitas $^{2}$ ), obra dum niilismo verdadeiramente perturbador: dada a variedade das correntes filosóficas, e ainda devido ao tempo e esforço necessários a uma séria apreciação de cada uma, o homem, por mais que faça, não pode atingir a verdade. Basta citar uma frase, que, não sendo de modo nenhum a mais importante deste diálogo, é, no entanto, verdadeiramente lapidar: "As pessoas que se dedicam à filosofia lutam pela sombra dum burro" (\$71). E, já agora, aqui fica o fecho, em que Hermotimo, finalmente convencido pelos argumentos de Licino (ou seja, Luciano), afirma: "Quanto aos filósofos, se por acaso, e apesar das minhas precauçóes, topar com algum no meu caminho, evitá-lo-ei, fugirei dele como dum cão raivoso». (\$ 86)

Cerca de vinte anos depois de chegar a Atenas, Luciano decide recomeçar a viajar, mas nada será como antigamente:

\footnotetext{
${ }^{2}$ «Clássicos Inquérito», n 16.
} 
já na recta final da existência, talvez em situação financeira menos próspera, e sem dúvida desiludido com o deteriorado clima cultural de Atenas, fixa-se no Egipto, onde aceita (ou consegue?) um lugar de funcionário público, aliás compatível com a sua formação e importância social. Ele próprio nos informa (Apologia dos Assalariados, $\$ 12$ ) de que a sua situação não se compara à dos miseráveis funcionários (por exemplo: professores), que afinal não passam de escravos. E continua: « $A$ minha condição, meu caro amigo ${ }^{3}$, é completamente diferente. $\mathrm{Na}$ vida privada, conservei toda a minha liberdade; publicamente, exerço uma porçâo da autoridade suprema, que administro em conjunto com o procurador... Tenho sob a minha responsabilidade uma parte considerável da provincia do Egipto, cabe-me instruir os processos, determinar a ordem pela qual devem dar entrada, manter em dia os registos exactos de tudo o que se diz e faz, ... executar integralmente os decretos do Imperador... E além do mais, o meu vencimento não se parece nada com o dum simples particular, mas é digno dum rei, e o seu montante, longe de ser módico, ascende a uma soma considerável. A tudo isto acrescenta o facto de eu não me alimentar de esperanças modestas, pois é possivel que ainda obtenha a titulo pleno a prefeitura ou qualquer outra função verdadeiramente real.»

Esperanças nada modestas, provavelmente bem fundadas... Só que, por motivos que ignoramos, tudo se desfez em vento.

${ }^{3}$ Esta obra, de forma epistolar, é dirigida a Sabino, amigo de Luciano. 
CONTRA OS ASSALARIADOS DOS GRANDES 
(Página deixada propositadamente em branco) 


\section{INTRODUÇÁO}

Antes de mais, diga-se que esta obra se refere a uma instituição tipicamente romana, a clientēla, que estabelecia uma certa relação entre o protegido, cliens, "o cliente", ou protegida, clienta "a cliente" e o protector, patrōnus, "patrono", ou a protectora, patrōna, "patrona”, ou seja, o grande senhor ou a grande senhora da alta classe romana.

O cliente podia ser um antigo escravo, ou seja, um libertus, que continuava ao serviço do senhor, e até usava o nome de família, o gentile nomen, do senhor.

Mas o cliente também podia ser um indivíduo de condição livre, romano ou estrangeiro (muitas vezes grego), que entrava ao serviço dum patrono, mediante um contrato e a fixaçáo dum salário. Este cliente, tal como os liberti, acompanhava o senhor nos seus passeios ou nas suas viagens, apoiava-o nas suas campanhas eleitorais, divertia-o, no caso de ter alguma habilidade especial, ou servia-lhe de apoio cultural (por vezes mais com espavento do que por verdadeiro interesse intelectual), era professor de primeiras letras dos filhos do senhor, ministrava disciplinas como Retórica, Filosofia, etc.

A instituição da clientela obrigava, muitas vezes, a executar tarefas mais ou menos penosas e muito absorventes, principalmente se o patrono era pessoa de mau humor, de mau trato e exigente.

Muitos intelectuais gregos percorriam o Império no exercício de uma profissão liberal (sobretudo Retórica e Filosofia), que poderia proporcionar-lhes bons rendimentos, como aconteceu com Luciano. De toda a maneira, não conviria a um homem livre (lat. liber, gr. eleútheros: $\dot{\lambda} \lambda \varepsilon \dot{\theta} \theta \varepsilon \rho \varsigma$ ) submeter-se ao serviço assalariado, ou à servidão, de um senhor, fosse ele o mais influente dos patrícios. Apesar disso, não faltava, entre a classe intelectual grega, quem se sentisse atraído pela convivência com os poderosos, que lhes transmitiam um certo sentimento de superioridade e alguma segurança material. Isto na melhor das hipóteses...

Nesta fase, Luciano leva uma vida desafogada, talvez ainda como mestre de Retórica por conta própria, ou então como puro intelectual e escritor, a viver da fortuna acumulada. Podemos entrever - simples e gratuita suposição — que, à semelhança de tantos outros, teria sentido uma leve tentação de enveredar 
por essa vida de intelectual assalariado. Pelo menos, verificava que alguns dos seus amigos o faziam. Um deles, Tímocles (que até pode não ser personagem real, mas simbólica de muitos outros: o nome significa "ambicioso"), está mesmo decidido a entrar nessa vida de servidão. Leia-se parte do $\$ 3$ :

"Ora, para que a minha pessoa, um dia mais tarde, fique livre de culpa e para que tu náo possas dizer que eu, ao ver-te prestes a engolir um tal anzol juntamente com o camarão, não te retive, nem te impedi antes de o anzol se cravar na tua garganta, nem te avisei a tempo, mas, pelo contrário, esperei até te ver, içado e já cravado, arrastado e levado à força, enquanto eu chorava por ti, mas inutilmente... Então, para que tu nunca me faças tal acusação, [que seria] muito justa e irrefutável, se porventura fosse feita, ou seja, que eu errei por não te ter avisado, escuta tudo desde o principio e observa previamente a rede em si mesma e a nassa sem [abertura de] saida, mas estando tu da parte de fora, e não da parte de dentro e lá mesmo no fundo; toma nas tuas máos o anzol recurvado e a ponta do gancho virada ao arrepio, bem como as pontas do triplo arpão, experimenta-os nas tuas bochechas bem cheias, a ver se não te parecem muito aguçados, dificeis de retirar, dolorosos pelos seus ferimentos, rasgando violentamente [a carne] e fixando-se irresistivelmente, e então inscreve-me entre as pessoas cobardes e, por isso mesmo, famintas; e tu, exortando-te a ti mesmo a ter coragem, atira-te à presa, à tua vontade, e, tal qual uma gaivota, engole o engodo de uma só vez."

A tradução do título desta obra por Contra os Assalariados dos Grandes, não é fiel ao título dado pelos manuscritos, em que se lê mais ou menos o seguinte: Sobre os que servem (?) por salário. Mas é evidente que Luciano se mostra contrário a essa vida de assalariado ao serviço dos grandes senhores romanos.

Pela boca morre o peixe... Muitos anos passados, Luciano fixa-se no Egipto, onde aceita (ou consegue?) um lugar de funcionário público, aliás compatível com a sua formação e importância social. Ele próprio nos informa (Apologia dos Assalariados dos Grandes, $\$ 12$ ) de que a sua situação não se compara à dos miseráveis funcionários (por exemplo: professores), que afinal não passam de escravos. 
Quer dizer que o homem que antes criticara os que vendiam a sua liberdade, agora vê-se constrangido a aceitar um lugar no funcionalismo público. Inevitavelmente, vem-lhe à memória aquele escrito de outros tempos, em que sobranceiramente tenta desviar o seu amigo Tímocles de um modo de vida que ele abomina. 
(Página deixada propositadamente em branco) 


\section{Contra os Assalariados dos Grandes}

1. "Por onde começar", meu caro amigo 4 , e "por onde terminar" - como sói dizer-se ${ }^{5}$ — a narraçáo daquilo que precisam de suportar ou de fazer todos aqueles que servem mediante salário e entram nas relações de amizade dos poderosos (se é que pode ser denominada amizade essa sua escravidáo)? $\mathrm{Na}$ verdade, conheço muitos casos, ou mesmo muitíssimos, do que aconteceu a esses tais, não (por Zeus!) por ter experimentado tal situação, pois nunca me vi na necessidade de ter uma tal experiência - e queiram os deuses que nunca tenha! $!^{6}$-, mas pelo facto de muitos dos que caíram nessa vida mo terem relatado, uns, que ainda se encontravam nessa desgraça, lamentando-se das muitas e horríveis coisas que estavam a sofrer, e outros, como se se tivessem evadido de uma prisão, recordando, não sem prazer, os males por que haviam passado. Na verdade, eles gozavam ao recapitularem os males de que se haviam libertado.

Estes últimos eram até mais dignos de fé, por terem passado, digamos, por todo o ritual e por se terem iniciado em todos os graus, do princípio até ao fim. Não era, pois, superficialmente e sem grande atenção que eu os escutava, como se estivessem a narrar-me um naufrágio e a sua salvação deste, tal como aquelas pessoas que se encontram aos magotes junto dos santuários, de cabeça rapada, narrando as enormes vagas, as tempestades, os promontórios e os escolhos, o mastro quebrado e o leme feito em pedaços, e, depois de tudo isso, a aparição dos Dioscuros $^{7}$ — divindades habituais neste tipo de tragédia ou de qualquer outro deus ex machina ${ }^{8}$ de pé no alto do mastro ou [agarrado] ao leme, dirigindo o navio para uma praia macia

${ }^{4}$ Este "caro amigo" é um tal Tímocles, mencionado mais adiante, e do qual nada mais sabemos, a náo ser que se preparava para enveredar pela vida de assalariado ao serviço de um grande senhor romano.

${ }^{5}$ Referência a um passo da Odisseia, IX, 14, com alguma adaptação.

${ }^{6}$ No fim da vida, Luciano aceitou (ou conseguiu) um cargo burocrático na administração da província do Egipto: v. Apologia dos Assalariados...

7 Os Dioscuros (lit. "e "filhos de Zeus") são, em particular, os gémeos Castor e Pólux, que, entre outras funçôes, eram os protectores da navegação.

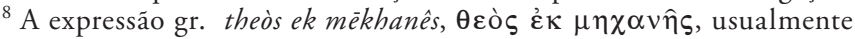
traduzida pela expressão latina deus ex machina, significava um processo usado no teatro, em que, perante uma situaçáo humanamente insolúvel, levava-se à cena, através duma espécie de guindaste, uma divindade que ditava a resoluçáo do problema. 
onde ele pode aportar tranquilamente e desfazer-se com todo o vagar, enquanto os tripulantes desembarcam em segurança, pela graça e benevolência da divindade.

A maior parte das vezes, esses homens dramatizam exageradamente os acontecimentos em função da necessidade imediata, a fim de receberem [dinheiro] de um maior número de pessoas, as quais vêem neles não só uns desgraçados, mas também pessoas queridas dos deuses.

2. Aqueles, porém, [os assalariados,] narram as tempestades domésticas", as 'triplas-vagas' ${ }^{10}$ e, por Zeus!, as 'quintas-vagas', e até mesmo as 'décimas-vagas', se assim podemos dizer, contando como, no princípio, navegaram num mar aparentemente calmo, mas depois quantas complicaçóes suportaram durante toda a viagem, sequiosos, enjoados, encharcados com água salgada e, por fim, como, depois de despedaçarem o desventurado navio contra alguma rocha submersa ou um recife escarpado, os desgraçados conseguiram penosamente escapar a nado, completamente privados de todos os bens necessários [à vida]. No meio de tudo isto, e pela sua própria narrativa, pareceu-me que estes últimos me escondiam, por vergonha, a maior parte dos factos e deliberadamente tentavam esquecê-los.

Mesmo assim, meu caro Tímocles ${ }^{11}$, não hesitarei em expor-te todos esses factos, bem como outros que descobri por dedução lógica, e que se adequam a um tal relacionamento, pois julgo ter-me apercebido de que tu já desde há muito andas a magicar entregar-te a esse modo de vida...

3. [e apercebi-me disso,]... em primeiro lugar, quando uma vez a conversa recaiu sobre esse tema, e depois um dos presentes se pôs a elogiar essa tal vida de assalariado, dizendo que eram sumamente felizes aqueles que, além de terem como amigos

${ }^{9}$ Todo este passo está em linguagem figurada, comparando a vida dos assalariados à dos homens do mar...

10 "triplas vagas": um pouco atrás traduzi por "enormes vagas" o termo gr. (acusat.) trikümias ( $\tau \rho \imath \kappa v \mu i \alpha \varsigma)$, que significava "conjunto de três vagas" (a última das quais era maior e mais perigosa). Imediatamente a seguir, porém, o narrador superlativiza o tamanho das vagas, chamando-lhes pentakümías ( $\pi \varepsilon v \tau \alpha \kappa v \mu i ́ \alpha \varsigma)$ "quinta-vaga" e (náo contente com o

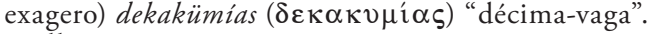

${ }^{11}$ Tímocles é, sem dúvida, uma personalidade real, ainda que, para nós, desconhecida por outra via (Plínio menciona um estatuário com esse nome). 
os mais excelentes dos Romanos, além de participarem em jantares luxuosos sem [contribuírem com] a sua quota-parte, além de viverem numa bela casa e além de viajarem com toda a comodidade e com todo o prazer num carro puxado por uma parelha de cavalos brancos e, calhando, com ar enfatuado ${ }^{12}$, ainda por cima têm um salário nada módico em troca da amizade e do bom tratamento que recebem. Para estas pessoas, todos esses bens lhes nascem espontaneamente, sem serem semeados nem arados ${ }^{13}$. Entáo, enquanto tu escutavas essas e outras coisas que tais, eu reparava como estavas de boca aberta para essas [maravilhas] e oferecias a boca, atirando-te ao isco.

Ora, para que a minha pessoa ${ }^{14}$, um dia mais tarde, fique livre de culpa e para que tu não possas dizer que eu, ao ver-te prestes a engolir um tal anzol juntamente com o camarão ${ }^{15}$, náo te retive, nem te impedi antes de o anzol se cravar na tua garganta, nem te avisei a tempo, mas, pelo contrário, esperei até te ver, içado e já cravado ${ }^{16}$, arrastado e levado à força, enquanto eu chorava por ti, mas inutilmente. Então, para que tu nunca me faças tal acusação, [que seria] muito justa e irrefutável, se porventura fosse feita, ou seja, que eu errei por náo te ter avisado, escuta tudo desde o princípio e observa previamente a rede em si mesma e a nassa ${ }^{17}$ sem [abertura de] saída, mas estando tu da parte de fora, e náo da parte de dentro e lá mesmo no fundo; toma nas tuas máos o anzol recurvado e a ponta do gancho virada ao arrepio, bem como as pontas do triplo arpão ${ }^{18}$, experimenta-os nas tuas bochechas bem cheias, a ver se não te parecem muito aguçados, difíceis de retirar, dolorosos pelos seus ferimentos, rasgando violentamente [a carne] e fixando-se irresistivelmente, e então inscreve-me entre as pessoas cobardes

12 "com ar enfatuado": é talvez esta a melhor interpretação do parti-

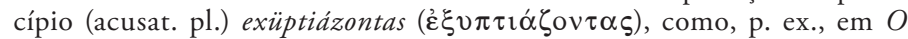
Bibliómano ignorante, $21 \ldots$

${ }^{13}$ Odisseia, IX, 109, com adaptação.

14 "minha pessoa": o gr. tem o plural majestático; do mesmo modo a seguir, os verbos estão no plural, mas resolvi traduzir pelo singular real.

${ }_{15}$ Trata-se de um pequeno camarão que serve de isco.

16 "içado e já cravado": é uma tradução possível; o texto apresenta algumas dificuldades.

17 "nassa": espécie de cesto de vime entrelaçado, onde os peixes penetram, mas que náo os deixa sair.

${ }^{18}$ A triaina $(\tau \rho i \alpha \imath \vee \alpha)$ significa, habitualmente, um tridente (caracterizadamente o tridente de Posídon), ou um arpão em forma de forquilha de três pontas, usado para caçar peixe graúdo; outros sentidos, v. dicionários. 
e, por isso mesmo, famintas; e tu, exortando-te a ti mesmo a ter coragem, atira-te à presa, à tua vontade, e, tal qual uma gaivota $^{19}$, engole o engodo de uma só vez.

4. Todos este meu discurso será, no seu conjunto, dirigido a ti em particular, mas não só a vós todos, professores de Filosofia, nem somente a quantos optaram por esta carreira muito séria, mas é também dirigido aos professores de primeiras letras, aos retores ${ }^{20}$, aos músicos e, de uma maneira geral, a todos aqueles que aspiram a servir [os grandes senhores], mediante salário, na área da educação. Ora, sendo, na generalidade, a sua situação comum e idêntica para todos, é óbvio que ela não é mais favorável para os professores de Filosofia, mas é até mais vergonhosa, precisamente por ser a mesma, já que seriam tratados da mesma maneira que os outros, e os seus patróes não teriam por eles maior consideração. Mas seja o que for que este meu discurso sucessivamente ponha a descoberto, são os próprios que praticam tais actos, e logo a seguir aqueles que os suportam, que devem, muito justamente, apanhar com a acusação. Eu é que estou inocente... a não ser que haja algo de condenável na verdade e na franqueza.

No que respeita às pessoas pertencentes ao resto da populaça, como certos treinadores de atletas e certos bajuladores, gente vulgar, tacanha de espírito e de baixa condição natural, não merecem sequer que tentemos desviá-los de tais relaçóes, pois não se deixariam convencer, nem está certo acusá-los pelo facto de náo abandonarem os seus patrôes, apesar de a maior parte das vezes serem por estes muitíssimo ultrajados. Na verdade, estão moldados a isso e não desmerecem desse modo de vida. De outra maneira, náo teriam mais nada para que se voltar e que pudesse mantê-los em actividade, porquanto, se os privassem desse modo de vida, ficariam imediatamente sem trabalho, ociosos e inúteis. Portanto, nem esses fulanos sofreriam algo [que fosse] degradante, nem os seus patróes pareceriam — como sói dizer-se — “mijar no penico" 21 . De facto, foi para sofrer

${ }^{19}$ Para os antigos, a gaivota era um dos símbolos da voracidade... ideia muito longe de... "Uma gaivota voava, voava...", da canção de Abril...

20 "retores": oradores, mas especialmente, neste caso, mestres de Retórica; do mesmo modo, "músicos" é aqui, propriamente, "professores de música".

${ }^{21}$ Entenda-se: “... pareceriam mijar-lhes em cima, como no penico”, isto é, tratá-los de maneira desumana... abaixo de cáo. 
esse ultraje que eles, logo de início, entraram para essas casas: o seu ofício consiste [precisamente] em aturar e suportar tudo isso. Pelo contrário, no que respeita àqueles a que acima me referi, aos homens cultos, tenho o dever de me indignar e de tentar, o mais que eu puder, guiá-los e devolvê-los à liberdade.

5. Julgo proceder bem, se, analisando previamente os motivos pelos quais certos homens se entregam a esse modo de vida, mostrar que [esses motivos] náo são nem fortes nem prementes. Deste modo, ficaria desde logo arredada a sua justificação, bem como o primeiro argumento em favor da sua servidáo voluntária. Na sua maior parte, ao alegarem a penúria e a falta de meios, cuidam que essa capa que colocaram é suficiente para [justificar] a deserçáo para esse modo de vida, e julgam que lhes basta dizer que merecem desculpa, pelo facto de procurarem escapar à coisa mais penosa da vida - a pobreza. Depois, têm Teógnis logo ali à mão, e com frequência:

\section{Pois todos os homens são | da pobreza dominados 22}

e citam todos os outros papóes que os mais ignóbeis poetas desencantaram sobre a pobreza

Se eu ao menos visse que eles encontravam realmente nesse relacionamento algum refúgio contra a pobreza, não lhes falaria minuciosamente a favor da liberdade plena. Uma vez, porém, que eles - como dizia algures o bom do orador ${ }^{23}$-, recebem uma alimentação semelhante à dos doentes, com que argumento especioso querem convencer-nos de que não decidiram mal nessa matéria, quando a condição da sua vida permanece sempre a mesma ${ }^{24}$ ? Na verdade, a pobreza é permanente, a necessidade de receber é sempre urgente, não póem dinheiro de lado, não economizam nada, mas, pelo contrário, o [dinheiro] que lhes dão, se dão, ou se o recebem todo junto, é completamente gasto e inferior às necessidades. Seria bom que não inventassem formas como estas, que, só com pequenas ajudas, apenas mantêm a pobreza, mas que a eliminassem por

22 v. 177.

${ }^{23}$ Demóstenes, 3a Olíntia, 33. A citação, feita de cor, não é literal, mas é, mesmo assim, correcta quanto ao sentido geral.

24 "sempre a mesma", ou seja, igual à que tinham antes de entrarem ao serviço do grande senhor. 
completo e, nesta ordem de ideias, talvez que, como tu dizes, ó Teógnis ${ }^{25}$,

$$
\begin{array}{r}
\text { [devessem] ....... | de rochedos escarpados } \\
\text { | lançar-se no mar profundo. }
\end{array}
$$

Ora, um homem sempre pobre, carente e assalariado, e que cuida que deste modo escapa à pobreza, não sei como é que não dá a impressáo de andar a enganar-se a si próprio.

6. Outros afirmam que não temeriam nem se amedrontariam com a pobreza em si mesma, se fossem capazes de ganhar a vida com trabalho, como as outras pessoas, mas que presentemente têm padecimentos físicos, quer por velhice, quer por doença, pelo que recorreram à condiçáo de assalariados, por ser mais cómoda. Ora bem, vejamos se falam verdade e se aquilo que lhes dão é conseguido com mais comodidade e se eles não penam muito, ou náo mais que as outras pessoas. De facto, seria algo parecido com uma graça divina, isto de uma pessoa, sem trabalho e sem esforço, obter dinheirinho vivo. Mas na verdade, náo se pode dizer que as coisas se passam conforme o mérito [de cada um] ${ }^{26}$. [Pelo contrário,] trabalham e penam tanto nessa sua relação de vassalagem, que necessitam de ter, nessas casas, mais robustez para desempenhar a sua obrigação, dado que todos os dias aparecem milhares de tarefas que massacram o corpo e o esgotam até ao cúmulo do desespero. Em devido tempo falaremos deste assunto, quando enumerarmos os outros dissabores. Neste momento, basta-me mostrar não falam verdade aqueles que afirmam que foi por esse motivo que se venderam.

7. Por último - motivo muitíssimo verdadeiro, mas que de modo nenhum confessam — é com a mira no prazer e na expectativa de obterem muitas e grandes vantagens, que eles se atiram a essas casas, pasmados com a enorme quantidade de ouro e prata, maravilhados com os jantares e com todos os outros luxos, na esperança de muito em breve virem a beber por taças de ouro, às goladas e sem que ninguém lhes ponha

${ }^{25}$ vv. $175-176$, versos só citados em parte.

${ }^{26}$ A frase é de difícil entendimento, os tradutores fazem o melhor que podem... 
um freio. É isso que os seduz e faz deles escravos em vez de homens livres, e não, como declaram, a falta do necessário à vida, mas sim a ambição do supérfluo e a apetência por todas essas coisas magníficas. Então, como [acontece com] os apaixonados mal amados e infelizes, os objectos do seu amor, experientes e manhosos, embora recebendo-os, tratam-nos com desdém, para que eles estejam sempre apaixonados e os sirvam, permitindo-lhes gozar alguma coisa da pessoa amada, mas só até ao ponto de [lhes concederem] um [ou outro] beijo, mas só com a ponta dos lábios, pois bem sabem que o gozo [completo] acarretará a dissolução do amor, que eles excluem e de que se defendem ciosamente; de resto, mantêm o apaixonado sempre esperançado, por temerem que o desespero o faça perder a enorme paixão e que ele deixe de os amar. Por isso, sorriem-lhe e dão-lhe esperanças de que um dia procederáo bem com ele, lhe serão agradáveis e o tratarão magnificamente. Depois, sem darem por isso, envelhecem ambos, passam da idade: um de desejar, outro de proporcionar [desejo]. Portanto, durante toda a vida nada fizeram senão esperar.

8. O facto de uma pessoa suportar todos os incómodos por desejo de [conseguir] prazer talvez não seja completamente censurável, mas é até desculpável, se essa pessoa gosta do prazer e faz de tudo para o alcançar. No entanto, é talvez acto vergonhoso e digno de um escravo o facto de a pessoa se vender por prazer. Na verdade, é de longe mais agradável o prazer que resulta da liberdade. Mesmo assim, porém, conceda-se-lhe alguma desculpa, se conseguiu [esse objectivo]. Mas o facto de suportar tantos dissabores somente na expectativa de alcançar o prazer é, julgo eu, coisa caricata e insensata, sobretudo quando vemos que os tormentos são certos, evidentes e inevitáveis, ao passo que o prazer que se espera, qualquer que ele seja, nem aconteceu até à presente data, nem, além disso, dá mostras de vir a acontecer, se fizermos os cálculos com base na realidade. $\mathrm{Na}$ verdade, os companheiros de Ulisses, ao comerem o doce lótus, esqueciam-se de tudo e, apegados ao momento presente, descuravam o seu dever. Mesmo assim, esse seu esquecimento do dever não era completamente disparatado, uma vez que o seu espírito estava todo absorto nesse grande prazer. Mas que um homem esfomeado esteja junto de outro que se farta de lótus, sem nada lhe dar, e, só movido pela esperança de um 
dia lhe ser permitido provar do mesmo, perca a noção do que é certo e justo fazer, ó Héracles! ${ }^{27}$, é coisa sumamente caricata e verdadeiramente merecedora de uma boa sova homérica ${ }^{28}$.

9. Os motivos que os levam a essa servidão e pelos quais [motivos] se entregam aos ricos e permitem que estes usem deles como muito bem entendem, são estes, ou outros muito próximos destes, a não ser que pretendamos mencionar também aqueles que, por vaidade, se deixam seduzir pela convivência dos nobres e purpurados ${ }^{29}$. De facto, há pessoas que cuidam que isso os torna mais considerados e superiores à maior parte das pessoas. Cá por mim, não aceitaria entrar na intimidade ou ser visto como íntimo até mesmo do Grande Rei, se não tirasse algum benefício dessa intimidade.

10. Uma vez admitida esta motivação, vejamos agora, só cá para nós, que incómodos têm de suportar antes de conseguirem ser admitidos, aquilo que sofrem depois, já nessa situação, e por cima de tudo isso, qual será o desenlace fatal da peça ${ }^{30}$. $\mathrm{Na}$ verdade, não se pode dizer que essa situaçáo, ainda que penosa, seja fácil de conseguir e não requeira muito trabalho, mas somente vontade, com o que, logo a seguir, tudo ficaria realizado com toda a facilidade. Pelo contrário, precisarás de muitas correrias, de noites inteiras à porta [do senhor], de te levantares [da cama] bem cedinho e aguardar acotovelado [pelos outros], impedido de entrar, algumas vezes tratado por petulante e maçador por um porteiro que fala pessimamente a língua síria e dependente de um anunciador ${ }^{31}$ líbio $^{32}$ a quem dás uma gorjeta para que se recorde do teu nome. Além disso,

27 “ó Héracles” ou, mais livremente, “que diabo!”, ou “caramba!”...

${ }^{28}$ Referência a Tersites, o mais feio, mais deformado e mais cobarde de entre os gregos que tentavam tomar Tróia. Quando Agamémnon sugeriu que se levantasse o cerco da cidade, logo Tersites o apoiou. Nesta cena, o desgraçado apanhou uma sova monumental ministrada por Ulisses... (Iliada, II, 199..., 265...).

29 "nobres e purpurados". ou seja (no tempo de Luciano: época romana), patrícios e magistrados: senadores, cônsules, pretores, generais...

30 "desenlace fatal da peça": Luciano utiliza mesmo a linguagem teatral.

31 "anunciador" é um cargo tipicamente romano, o de nomenclator, escravo encarregado de lembrar ao senhor o nome dos seus apoiantes políticos ou de outras pessoas da sua comitiva, e ainda de anunciar o nome da pessoa que se apresentava logo de manhã em casa do senhor...

32 "líbio" significava "africano em geral" (Egipto e todo o norte de África). 
precisas: de arranjar vestuário acima das tuas reais possibilidades [financeiras], como sinal de consideração por aquele que tu serves, de e escolher as cores de que ele gosta, para que náo destoes e choques [o senhor] caso ele repare em ti, de o seguir penosamente, ou melhor, de caminhar à sua frente, acotovelado pelos criados e fazendo número na sua comitiva. Ele, porém, durante muitos dias seguidos nem sequer repara em ti.

11. Mas se por acaso tiveres sorte e ele olhar para ti, se te chamar e te perguntar uma coisa qualquer, então sim, então ficas alagado em suor, em completa confusão, uma risota para os presentes ao verem o teu embaraço. E muitas vezes, em vez de responderes à pergunta "Quem era o rei dos Aqueus", dizes que "eles tinham mil navios". A isto, as pessoas simpáticas chamam acanhamento, as atrevidas [chamam] timidez, e os pérfidos [chamam] ignorância. Então tu, depois de experimentares esta primeira, e falhada, manifestação de afabilidade [do patrão], retiras-te maldizendo o teu grande desespero. E depois de ${ }^{33}$

\section{... passares $\mid$ muitas noites sem dormir}

e dias ensanguentados $\mid . .$.

cumprires, não, por Zeus!, por causa de Helena, ou da cidadela de Pérgamo, do rei Príamo, mas pelos almejados cinco óbolos, e depois de dares com algum deus de tragédia que te acuda, virá a tua prova de exame, a ver se conheces as ciências ${ }^{34}$. Para o ricaço, esta ocupação não é nada desagradável, pois ele é que é elogiado e felicitado, mas para ti parece tratar-se de uma luta de vida [ou de morte], que implicará toda a tua existência. $\mathrm{Na}$ verdade, ocorre-te a ideia de que muito naturalmente não serias acolhido por outro [senhor], depois de seres rejeitado pelo primeiro e de teres sido considerado reprovado. Deste modo, é forçoso que, nesse momento, te vejas dividido em mil [preocupaçôes], com ódio aos co-examinandos teus rivais admite que há outros a disputarem o mesmo que tu - , e tu a julgares ter respondido de modo deficiente, fixando, cheio de temor e de esperança, o rosto do senhor: se ele deprecia alguma

${ }^{33}$ Ilíada, IX, 325-326, citados parcialmente e com adaptação.

34 "as ciências", gr. tà mathémata ( $\tau \dot{\alpha} \mu \alpha \theta \dot{\eta} \mu \alpha \tau \alpha)$ parece referir-se às ciências matemáticas: Aritmética, Geometria e Astronomia. 
coisa que tu dizes, ficas para morrer, mas, se te escuta com um sorriso, ficas todo contente e cheio de esperança.

12. É natural que haja muitos que têm má impressão de ti e que preferem outros [candidatos] à tua pessoa. Cada um deles dispara setas contra ti, como se estivesse escondido numa emboscada. Então, imagina um homem de barba comprida e de cabelos brancos, a ser examinado sobre se sabe alguma coisa útil, e que uns julgam que ele sabe, e outros que não sabe. Decorrido algum tempo, é espiolhada toda a sua vida passada, e então, se uma qualquer pessoa, por exemplo um cidadão movido pela inveja, ou um vizinho ofendido por qualquer motivo sem importância, uma vez interrogado, afirmar que tu és um adúltero ou um pederasta, isso é [visto] como um testemunho [prestado] sobre as tábuas de Zeus, mas se todos, uns atrás dos outros e unanimemente, te elogiarem, são [considerados] suspeitos, duvidosos e subornados. Portanto, precisarias de ter muita sorte para que absolutamente nada te fosse contrário. $\mathrm{Na}$ verdade, só desse modo vencerias.

Pois ${ }^{35}$ seja assim, tudo te correu bem, até melhor do que ambicionavas: $\mathrm{O}$ senhor elogiou as tuas palavras, os mais estimados de entre os seus amigos e aqueles em que ele mais confia nessa matéria, não o dissuadiram, a sua esposa aprova, não se opóem nem o seu administrador nem o seu ecónomo, ninguém censurou a tua vida, enfim, tudo te é favorável, as vítimas são-te completamente propícias.

13. Venceste, felizardo, foste coroado em Olímpia, ou ainda melhor, conquistaste Babilónia ou tomaste de assalto a cidadela de Sárdis ${ }^{36}$, vais possuir o corno de Amalteia ${ }^{37}$ e vais “ordenhar

35 Alguns editores iniciam aqui o $\$ 13$. Sigo a edição da "Loeb”.

${ }^{36}$ Sárdis é a forma correcta em português, adaptada regularmente do gr. Sárdeis / Sárdis ( $\Sigma \alpha ́ \rho \delta \varepsilon \imath \varsigma / \Sigma \alpha ́ \alpha \delta \imath \varsigma)$, fem. pl.; Mesmo a forma com - ei-teria a mesma adaptação; de resto, a forma latina é precisamente Sardīs, correspondendo à pronúncia gr. [-ei-] > [-i-], cf. gr. Alexándreia, lat. Alexandria ... ; a forma Sardes é (como outras, indevidamente) tirada do francês. É certo que o uso (mesmo resultante de ignorância) faz lei...

${ }^{37}$ Amalteia é a ninfa ou a cabra que amamentou o pequeno Zeus, que sua mãe levou em segredo para Creta, a fim de fugir à voracidade assassina de seu pai. Crono. O corno da cabra recebera de Zeus o dom de estar sempre pejado de toda a qualidade de frutos: é a cornucópia ou "corno da abundância”. Note que, ao contrário da forma Sárdis (v. nota supra), o gr. 
leite de galinha"38. É realmente justo que alcances os maiores bens em paga de tantos trabalhos, que não ganhes simplesmente uma coroa de folhas, que o salário que te estipularem não seja desprezível, e que te seja pago sem complicaçóes e a tempo e horas, para [satisfazeres] as tuas necessidades, que recebas honrarias acima da maior parte das pessoas, que descanses de todos aqueles tormentos, da lama, das correrias, das noites sem dormir, enfim, e segundo o teu desejo, [mereces] estender as pernas e dormir, cumprindo somente aquelas tarefas para as quais foste inicialmente seleccionado e pelas quais és pago. Devia ser assim, ó Tímocles, e então não constituiria uma grande desgraça curvares-te e suportar um jugo tâo leve, tấo fácil de transportar e - o melhor de tudo - [um jugo] doirado. Mas longe disso, mesmo muitíssimo longe... Na verdade, há nestas relaçóes mil e uma coisas que se tornam insuportáveis para um homem livre. Ora vai escutando e vê lá se alguém, por pouco familiarizado que esteja com a cultura, poderia suportar tais incómodos.

14. Começo, se me permites ${ }^{39}$, pelo primeiro jantar em que, naturalmente, participarás, como cerimónia preliminar do futuro relacionamento.

Primeiro, vem alguém convidar-te a que vás ao jantar... um criado nada falho de boas maneiras, que terás logo de tornar simpático contigo, metendo-lhe na mão, para não pareceres grosseiro, pelo menos cinco dracmas. Ele, porém, fingindo recusar, diz: "O quê? Eu receber dinheiro de ti??", e ainda: "Por Héracles, isso nunca!"; mas por fim lá se deixa convencer, e sai, rindo-se de ti às gargalhadas. Entáo tu tomas banho, pegas numa veste lavada, vestes-te o mais elegantemente possível e lá vais, receando chegar antes dos outros, o que seria deselegante, tal como chegar depois seria grosseiro. Portanto, aguardas

Amálteia passou para o lat. Amalthēa, donde é adaptada a forma port.: $\bar{e} a>$ port. ea > eia (cf. lat. vēna- > port. arc. vea > veia...). A adaptação directa do gr. daria port. *Amaltia.

38 "leite de galinha", expressão proverbial, que quer dizer "coisa maravilhosa difícil de conseguir", "mundos e fundos”, "o cúmulo da felicidade”,,; os dicionários traduzem: ou "de galinha", ou "de galo", ou (com o sentido mais geral da palavra) "de ave(s)", ou mesmo ("Loeb") "pigeon's milk". A expressão chegou ao gr. mod. "leite de pássaro"...

39 "se me permites", lit. "te "se te parece (bem)" é uma fórmula de sentido mais vago que o seu sentido literal. 
o momento intermédio, e [só então é que] entras. O senhor recebe-te com todas as honras, e alguém, pegando-te pela mão, instala-te à mesa ${ }^{40}$, um pouco para além do ricaço e talvez ao lado de dois dos seus velhos amigos.

15. E tu, como se tivesses entrado no palácio de Zeus, admiras tudo, ficas suspenso e atento ${ }^{41}$ a tudo o que se passa. $\mathrm{Na}$ verdade, tudo aquilo te é estranho e desconhecido. A criadagem observa-te, cada um dos presentes espia o que tu irás fazer, e o próprio ricaço não fica indiferente, mas ordenou previamente a alguns dos criados que mirassem bem se tu, lá do teu lugar, olhavas com frequência para os seus filhos ou para a sua esposa; os [criados] acompanhantes ${ }^{42}$ dos convivas, ao verem-te embaraçado por inexperiência da etiqueta ${ }^{43}$, troçam de ti, dando como prova de que tu nunca antes tinhas jantado em casa de outra pessoa o facto o teu guardanapo ser novo ${ }^{44}$. Como se compreende, é inevitável começares a suar devido ao embaraço, e, cheiinho de sede, nem sequer te atreves a pedir de beber ${ }^{45}$, ainda assim não te julguem um beberrão; e ao veres tanta variedade de acepipes postos diante de ti e alinhados segundo uma determinada ordem, nem sabes para qual deves estender a mão em primeiro ou segundo lugar, pelo que precisas de dar uma olhadela furtiva ao teu vizinho, imitá-lo e, deste modo, ficar a saber a sequência do jantar.

40 "instala-te à mesa": O texto gr. diz só “inclina-te”, ou seja, faz-te tomar a posição de reclinado, apoiado num cotovelo e diante de uma mesa baixinha, à volta da qual estão outros dois comensais (v. texto a seguir).

41 "suspenso e atento": O adj. metéōros ( $\left.\mu \varepsilon \tau \varepsilon \dot{\varepsilon} \omega \rho_{\varsigma}\right)$ significa "suspenso no ar", em posição elevada”... "nas nuvens"... " de nariz no ar" e, naturalmente, com a conotação de "atento".

42 "[criados] acompanhantes": Pelos menos alguns convivas faziam-se acompanhar de um criado, ao qual, não raro, passavam furtivamente comida, que levavam para casa...

43 "da etiqueta": O texto diz " "das coisas que devem ser feitas", ou "da maneira de fazer as coisas"...

44 "guardanapo": gr. kheiMómaktron ( $\chi \varepsilon 1 \rho o ́ \mu \alpha \kappa \tau \rho o v)$ significa, etimologicamente, "limpa-máos", que era para isso que esse pano principalmente servia, pois não se usava faca e garfo...; naturalmente, também servia para limpar a cara. Depreende-se que cada conviva trazia de casa o seu guardanapo. Note outra interpretação: “... o facto de o [uso do] guardanapo] ser para ti uma novidade”. Parece preferível a primeira interpretação.

45 "beber": Vê-se pela sequência que se trata de "beber vinho". 
16. Por outro lado, sentes-te dividido, com a alma cheia de confusão, atónito perante cada acontecimento; ora exaltas a felicidade do rico, pelo seu ouro, pelo seu marfim e por tanto luxo, ora te lastimas, [dizendo] que não eras nada, mas que agora já sabes o que é viver. Algumas vezes, ocorre-te a ideia de que vais viver uma vida invejável, que vais gozar de todas aquelas delícias e participar delas com todo o direito. Realmente, cuidas que celebrarás continuamente as Dionísias ${ }^{46}$; e talvez uns mocinhos formosos postos ao teu serviço e sorrindo docemente te pintem o teu delicioso modo de vida, de modo que continuamente recites aquele verso homérico ${ }^{47}$ :

\section{Não é indigno Troianos | e polainudos Aqueus}

sofrerem e suportarem tantos males, em troca de uma tão grande ventura.

Mas eis que, chegado o momento dos brindes, o senhor pede uma taça ${ }^{48}$ das grandes e bebe à tua saúde, chamando-te "mestre" ou outra coisa qualquer. Então tu pegas na tua taça, mas, por falta de experiência, náo sabes que deves, por tua vez, dizer algumas palavras de resposta, com o que ganhas fama de labrego.

17. Além disso, devido àquele teu brinde, tornaste-te odioso para muitos dos velhos amigos [do senhor], aliás já desde antes, quando ofendeste alguns deles por causa do lugar [que te foi atribuído], porquanto, só hoje chegado, já foste preferido a homens que já tinham bebido até ao fim [a taça de] uma longa escravidão. E logo se ouve, entre eles, uma frase como esta, a teu respeito: "Só nos faltava cá isto a juntar às nossas outras desgraças: sermos secundarizados em relação aos recém-chegados a esta casa." E [acrescenta]: "A cidade dos Romanos está aberta só para estes gregos; e no entanto, por que motivo é que são preferidos a nós? Será que julgam que prestam um grande serviço, lá por pronunciarem uns discursozecos miseráveis?" E [vai daí]

${ }^{46}$ Dionísias ou Dionisíacas eram as festas em honra do deus Dioniso (Baco); havia várias festas, em diversas datas...

${ }^{47}$ Iliada, II, 156.

${ }^{48}$ Trata-se de uma espécie de tigela, um pouco mais larga que alta, com um diâmetro ligeiramente maior em cima que em baixo, com duas asas e sem pé; de tamanho variável. 
um outro: "Não viste a quantidade [de vinho] que ele bebeu, e como arrebanhou e devorou os pratos postos na sua frente? É um grosseirão, um esfomeado que nunca [na vida], nem mesmo em sonho, provou pão branco, nem galinha da Numidia ${ }^{49}$, nem faisão... de que só nos deixou os ossos." E um terceiro diz: "Ó meus caros amigos, em menos de cinco dias haveis de vê-lo aqui mesmo, no meio de nós, a lamentar-se da mesma desgraça. Sim, neste momento, como sucede com os sapatos novos, recebe honras $e$ atenção, mas assim que fizer constantes caminhadas e ficar coberto de lama, será lançado para debaixo da cama, [e ficará] cheio de percevejos... como nós."

Eis o que discorrem a teu respeito, e alguns deles já estão mesmo a maquinar calúnias [contra ti].

18. Assim, todo aquele banquete é [oferecido] em tua honra, e as conversas, na sua maior parte, são a teu respeito. Tu, porém, tendo bebido, sem estares habituado, mais que a conta de um vinho leve e acre, de há muito que estás com um [forte] aperto de barriga e te sentes [muito] mal, mas nem te fica bem levantares-te antes [dos outros], nem é prudente ficares [no teu lugar]. Então, à medida que a bebida se prolonga, mais conversas atrás de conversas, mais apresentaçōes de espectáculos atrás de espectáculos — pois [o senhor] quer patentear diante de ti toda a sua opulência — , tu sofres um tormento nada pequeno, não vês o que está a acontecer, nem ouves quem está a cantar ou a tocar cítara, um jovenzinho muito considerado... mas tu aplaudes só por obrigação, e só fazes votos por que um terramoto mande tudo aquilo abaixo ou que se declare um incêndio, para que, finalmente!, seja posto fim à festa.

19. Eis, pois, companheiro, o teu primeiro e mais delicioso jantar, não mais delicioso que as minhas cebolas [temperadas] com sal branco, que eu como à minha vontade, quando quero e quanto quero.

Mas ponhamos de lado a azia que se segue e os vómitos durante a noite. Logo de manhãzinha, tendes ambos de ajustar a questão do teu salário, quanto e em que data do ano deves receber. Na presença de dois ou três dos seus amigos, o senhor chama-te, manda-te sentar e começa a falar: "Já viste como é a nossa casa: não há nela qualquer ostentação, sem espavento teatral,

${ }^{49}$ A Numídia estendia-se desde a regiāo de Cartago à Mauritânia. 
tudo muito terra-a-terra e muito popular. É preciso que tu sintas que tudo aqui será comum entre nós. Sim, seria caricato, se eu, ao confiar-te a coisa mais preciosa, a minha alma ou, por Zeus!, as almas dos meus filhos - se porventura ele tivesse filhos que necessitassem de [receber] instrução —, não te considerasse igualmente senhor de tudo o resto. Em todo o caso, há que estabelecer um salário - e aqui verifico a moderação e a modéstia do teu carácter, e percebo que não foi pela expectativa de um salário que tu entraste na nossa casa, mas sim por outros motivos, pela afeição e pela estima [que receberás] da nossa parte, e que terás em todos nós. Em todo o caso, que seja estabelecido um salário. Tu próprio diz lá quanto queres [ganhar], mas lembra-te, meu caro, do que é habitual nós darmos pelas festas anuais. Na verdade, não nos esqueceremos desse ponto, muito embora não o incluamos neste contrato. De resto, há muitas oportunidades dessas durante o ano. Portanto, tendo em consideração tudo isso, é óbvio que nos exigirás um salário mais moderado. Aliás, fica muito bem a vós, pessoas cultas, serdes superiores a questóes de dinheiro."

\section{Ao dizer tais palavras, o senhor sacudiu completamente} o teu espírito com expectativas, e assim te domesticou em seu proveito. E tu, que desde há muito sonhavas com talentos ${ }^{50} \mathrm{e}$ com milhóes ${ }^{51}$, com campos imensos e casarios, apercebes-te pouco a pouco da mesquinhice [do senhor], mas consolas-te com a sua promessa e consideras que aquela frase "tudo será comum entre nós” é segura e verdadeira, sem saberes que tais palavras $^{52}$

${ }^{50} \mathrm{O}$ talento não era uma moeda propriamente dita, mas uma «moeda de conto" (cf. contos de réis) = 60 minas; uma mina = 100 dracmas; uma $\mathrm{dracma}=6$ óbolos. Portanto, um talento $=6000 \mathrm{dracmas}$. O termo talento podia referir-se, de maneira indeterminada, àquilo que designamos por "um balúrdio».

${ }^{51} \mathrm{O}$ gr. diz müriádes ( $\mu v \rho \imath \alpha ́ \delta \varepsilon \varsigma$ ) "grupos de dez mil”, aqui com o valor de numeração indeterminada = "grande quantidade", "balúrdios"... A expressão tálanta kai müriádes (v. também nota anterior a talentos) pode corresponder a port. mundos e fundos.

52 "tais palavras": o gr. diz, vagamente, "tais coisas", que especifico melhor. Note, porém, que, no texto homérico (Iliada, XXII, 495), a mesma expressão vaga refere-se a uma taça com vinho ou a umas gotas de vinho. Digamos que a expressão vaga permite a Luciano citar o verso homérico com um sentido algo diferente. O verso repete o verbo: "humedeceram os lábios, mas não humedeceram o palato". 
os lábios humedeceram, | mas ficou seco o palato.

Finalmente, por vergonha e respeito ${ }^{53}$, confias-lhe a questáo [do salário]. Ele, porém, recusa-se a estipular [a importância], e entấo pede a um dos seus amigos ali presentes que intervenha no assunto e fixe um valor que não seja pesado para ele, atendendo, além disso, a outras despesas que terá de fazer, mas também que náo seja muito baixo para quem vai receber. Entấo o amigo, um velho ainda viçoso, educado desde rapaz na [arte da] bajulação, diz: "Não podes dizer, meu caro, que não és o homem mais afortunado desta cidade, a quem, logo de comęo, calhou este privilégio, que muitos tanto desejam que lhes seja dado pela Fortuna. Refiro-me ao facto de teres sido julgado digno da convivência [do senhor], de partilhares da sua mesa ${ }^{54} e$ de seres recebido na primeira casa do Império Romano. Ora, se realmente sentes que és [um homem] moderado, esta situação está acima dos talentos de Creso e da fortuna de Midas. Quando vejo muitos homens de grande mérito, que o desejariam, mesmo que tivessem de pagar por isso, e só pela honra de conviverem com este [senhor] e de serem vistos como companheiros à sua volta e de serem considerados seus amigos, não posso deixar de te felicitar pela tua sorte, pois, além disso, ainda vais receber um salário por essa tua ventura. Portanto, julgo que, se não fores muito esbanjador, um salário de... - e indica uma quantia muito módica - chega-te bem, e ainda mais, se acrescentares aquelas outras perspectivas ${ }^{55}$."

21. No entanto, não tens outro remédio senáo contentar-te. $\mathrm{Na}$ verdade, já não te é possível fugir, pois já estás dentro da rede. Recebes o freio, de olhos e boca fechados ${ }^{56}$, e logo de início ficas ali, fácil de conduzir pelo senhor, o qual nem precisa de te puxar as rédeas nem de te picar com força, até que, sem te aperceberes, ficas completamente sujeito a ele.

53 "vergonha e respeito": o gr. aidós ( $\alpha i \delta \omega \varsigma \varsigma)$ significa ambas as coisas, e ainda "pudor", "timidez respeitosa"...

${ }^{54}$ Um dos sentidos de estía é "sala de jantar"; outro é o de "lar", parte mais íntima da casa, onde estava o altar dos deuses domésticos...

55 Trata-se de dinheiro adicional que os patróes costumavam dar pelas festas a nuais (v. \$19).

56 "de olhos e boca fechados": o verbo múō ( $\mu$ v́ $\omega)$ significa "fechar os olhos", mas também "fechar a boca" e, em sentido figurado "consentir". Os tradutores modernos optam quer por "de olhos fechados", quer por "de boca fechada”. Talvez a melhor tradução, ou pelo menos a mais castiça, seja "sem tugir nem mugir". 
Daí em diante, as pessoas de fora passam a invejar-te, ao verem-te a viver dentro da "jaula", entrando livremente e tornado alguém muito importante na casa. Tu, porém, ainda não percebes por que motivo é que essas pessoas te consideram feliz. Apesar disso, estás contente, iludes-te a ti próprio e continuas a acreditar que o futuro há-de ser melhor. Mas acontece [precisamente] o contrário do que tu esperavas, e a coisa passa-se como diz o provérbio a respeito de Mandrobulo, ou seja, dia após dia, [a tua felicidade] vai diminuindo e andando para trás ${ }^{57}$.

22. Entretanto, a pouco e pouco, entrevendo primeiro [a situação] como que através de uma luz difusa, começas a perceber que aquelas esperanças de ouro náo passavam de bolas de sabão com laivos dourados, ao passo que as tuas tribulaçóes eram pesadas, reais, inevitáveis e permanentes. "Mas que tribulaçôes são essas? - perguntar-me-ás — Na verdade, não vejo o que é que há de penoso em tais relaçóes de convivência, nem percebo que condiçôes dolorosas e insuportáveis são essas a que te referiste." Pois então, meu caro amigo, escuta e analisa, a ver se essa ocupação não só envolve [grande] penosidade, mas também se, na sequência do que vais escutar, não a achas, além disso, vergonhosa, humilhante e, em suma, digna de um escravo.

23. Antes de mais, lembra-te de que, desse momento em diante, deixas de te considerar uma pessoa livre e de família nobre. Na verdade, fica sabendo que linhagem, liberdade, antepassados, tudo isso deixarás lá fora, na rua, assim que te venderes e entrares em tal servidão. Sim, a Liberdade ${ }^{58}$ negar-se-á a acompanhar-te, se tu entrares numa actividade tão ignóbil e humilhante. Portanto, serás um escravo, por muito que este nome te custe, e serás fatalmente escravo não de uma única pessoa, mas de muitas, e, de manhã até à noite, servirás de

${ }^{57} \mathrm{O}$ provérbio grego, propriamente, era, lit..$^{\text {te }}$ " "a coisa corre como [aconteceu] com Mandrobulo", ou seja, como se explica a seguir. Este Mandrobulo, natural da ilha de Samos, tendo achado um tesouro, ofereceu a Hera, no primeiro ano, um carneiro de ouro; no segundo, um carneiro de prata; no terceiro, um carneiro de bronze, acabando por não oferecer nada. Em port., o mais próximo será: "Vai de mal a pior".

${ }^{58}$ Liberdade como conceito personalizado e divinizado, como (talvez!) a seguir: Escravatura. 
cabeça baixa, "por um salário miserável"59; e como um homem que náo foi criado desde rapaz na companhia da Escravatura, mas que só tardiamente e em idade avançada aprendeu e se formou nessa actividade, tu náo serás muito apreciado nem muito estimado pelo teu patrão. A insidiosa lembrança da liberdade consome-te e faz-te algumas vezes recalcitrar e, por isso, tentar, mas em vão, libertar-te da escravidão... a menos que consideres que, em termos de liberdade, te basta não seres filho de um qualquer Pírrias ou de um qualquer Zopírion ${ }^{60}$, ou não teres sido vendido, como um certo bitínio ${ }^{61}$, por um pregoeiro de voz forte. Mas, meu caríssimo amigo, quando, chegado o dia da lua nova ${ }^{62}$, tu, misturado com Pírrias e com Zopírion, estenderes a mão como os outros criados e receberes esse teu salário, qualquer que ele seja, isso é uma [autêntica] venda. $\mathrm{Na}$ verdade, nem é preciso pregoeiro, pois trata-se de um homem que se apregoa a si mesmo e que desde há longo tempo suspirava por ter um amo.

24. Além disso, ó porcaria de homem (nome perfeitamente aplicável a quem se gaba de filosofar), se, numa travessia por mar, um assaltante afundasse o teu barco e se apoderasse de ti, e algum pirata te pusesse à venda, lamentar-te-ias da tua má sorte tão imerecida; ou então, se alguém te levasse agrilhoado, reivindicando-te como escravo, tu invocarias as leis, farias uma grande algazarra e indignar-te-ias, clamando em alta voz " $O$ terra! Ó deuses!”. Agora, porém, será que te vendeste por uns poucos de óbolos, levando contigo o teu valor e a tua sabedoria, numa idade em que, se fosses escravo por nascimento, seria

${ }^{59}$ Os comentadores vêem nesta frase uma alusão a parte de um verso de Homero (p. ex., Odisseia, XIX, 341), onde se lê "numa cama miserável". Como, porém, a citação é nitidamente o final de um hexâmetro, pode muito bem tratar-se de citação de um poema perdido. De toda a maneira,

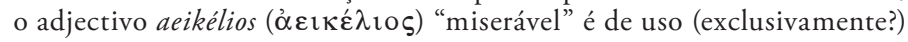
épico.

${ }^{60}$ Pírrias e Zopírion são nomes típicos de escravos; note-se que o texto diz, de maneira indefinida (falta de artigo definido... que é preciso traduzir) "um qualquer...".

${ }^{61}$ Ao contrário do caso precedente ("um qualquer Pírrias... um qualquer Zopírio", aqui diz-se "um certo bitínio", ou "um certo e determinado bitínio, o que sugere tratar-se de pessoa real, mas que Luciano náo acha prudente nomear.

62 "dia da lua nova” era, neste caso, o dia do pagamento de salários. 
o momento oportuno para aspirar à liberdade? ${ }^{63}$ Então nem sequer tens respeito por essas famosas obras escritas pelo bom do Platão, por Crisipo ou por Aristóteles, nas quais elogiam a liberdade e censuram a escravidão? Não te envergonhas de ser confundido com bajuladores, vagabundos e charlatães e de, no meio de uma turba de romanos, seres o único que o manto denuncia como estrangeiro, de estropiares grosseiramente a língua latina, e depois participares em ceias ruidosas e apinhadas de homens aos magotes, na sua maioria debochados? Nessas ceias, proferes elogios grosseiros e bebes mais do que é decente. Depois, logo de manhã, levantas-te ao toque da campainha, arrancado do sono mais doce, e caminhas com os outros para cima e para baixo [pela cidade] ${ }^{64}$, ainda com as pernas cheias da lama da véspera. Será que tinhas falta de tremoços ou de legumes bravos? Será que as fontes de água fresca deixaram de correr tão completamente, que foste forçado pelo desespero a entrar nessa vida? Ora, é óbvio que foste apanhado pela ambiçáo, náo de água nem de tremoços, mas sim de guloseimas, boa comida e vinho com perfume de flores, tal como o lobo-marinho, [com o anzol] cravado, e muito justamente, na goela que se estendia para o isco. Aí tens, pois, o preço dessa tua sofreguidáo. Tal como os macacos, tu, preso com uma coleira ao pescoço, és objecto de risota para as outras pessoas; julgas viver no luxo, só porque te é dado comer à farta passas de figo. Mas a tua liberdade e a tua nobreza, mais os [amigos] da tua tribo e da tua fratria, tudo isso se foi, e já nem tens memória dessas coisas.

25. Mas ainda irias com sorte, se a vergonha consistisse somente no facto de fazeres figura de escravo, em vez de homem livre, e se os teus trabalhos náo fossem exactamente como os dos autênticos escravos. Ora vê lá se te são impostos trabalhos

${ }^{63}$ Em Roma, muitos escravos de longo tempo conseguiam ganhar a condição de liberti em relação ao seu antigo dono, que passava a ser seu patronus; do ponto de vista social, tinha a categoria de libertinus, designação que transmitia aos filhos. O libertus ficava ligado ao seu senhor até ao fim da vida e adoptava o nome de família do patronus, mas não era cidadão de pleno direito (ciuis optimo iure): tinha o direito de propriedade e o direito de voto, mas náo podia aceder às magistraturas (questor, pretor, cônsul...).

${ }^{64}$ Quando o senhor saía a passear, era acompanhado por um séquito numeroso, num espavento de poder e riqueza... 
mais leves do que os impostos ao Drómon ou ao Tibio ${ }^{65}$ E quanto ao motivo pelo qual o senhor afirmava que te pretendia e que por isso te recebeu, ou seja, os teus conhecimentos, estes pouco lhe importam. "Que é que há de comum" - diz-se "entre uma lira e um burro?". Eles ${ }^{66}$ estão mesmo - então não estás a ver? - mortos de paixão ${ }^{67}$ pela sabedoria de Homero, ou pela eloquência de Demóstenes, ou pela magnificência de Platão. Se alguém lhes tirar da alma o seu ouro, a sua prata e as suas preocupaçóes com essas coisas, o que resta é fumaça, moleza, volúpia, dissolução, insolência e ignorância. É claro que ele não precisa mesmo nada de ti para estas coisas, pois tu tens uma barba farta, és um homem de rosto venerável, usas a preceito um manto grego, e toda a gente sabe que tu és um gramático, um retor ou um filósofo, pelo que o senhor considera que lhe fica bem ter um homem como tu misturado com os que o precedem e formam a sua escolta, pois desse modo aparecerá como estudioso das ciências gregas e, em suma, amante da cultura. Assim, meu caro, corres o risco de ter sido contratado, não pelos teus admiráveis discursos, mas pela tua barba e pelo teu manto.

Tens, pois, a obrigação de seres visto na sua companhia, sem nunca o largares, mas também deves levantar-te logo de manhã e apresentar-te para seres visto no meio da criadagem, e não deves abandonar o teu posto. Então o senhor, pondo-te por vezes a máo por cima do ombro, diz uma qualquer balela que lhe ocorra à mente, mostrando a quem encontram que nem mesmo a caminhar no meio da rua se descuida das Musas, mas que até mesmo em passeio tira proveito do ócio.

26. E tu, desgraçado, umas vezes correndo ao lado dele, outras vezes calcorreando ladeiras acima e ladeiras abaixo — sabes bem como é a cidade — , ficas escorrendo em suor e esbaforido, e então ele vai a casa de um amigo e fica lá a conversar, enquanto tu, não tendo onde te sentares, ficas ali de pé e, sem saberes o que fazer, póes-te a ler o livro de que te tinhas munido.

${ }^{65}$ Drómon e Tibio são nomes típicos de escravos; cf. $\$ 24$, nota a Pírrias e Zopírion. Neste caso, o uso do artigo pode indicar a referência explícita a escravos bem determinados.

66 "Eles": Refere-se, obviamente, àquele senhor e a todos os outros. Poderíamos traduzir por "Essa gente...".

67 "mortos de paixão": É óbvia a ironia. 
E quando a noite te surpreende ainda sem teres comido nem bebido, tomas um banho e, a uma hora indecentemente tardia, aí por volta da meia-noite, vais finalmente jantar, não, porém, como antes, cumulado de honras e atenções por parte dos convivas, mas, pelo contrário, se um outro, um novato, foi admitido, tu passas para trás. Assim, és atirado para o canto mais abjecto, onde ficas apenas como testemunha das iguarias que te passam ao lado, roendo ${ }^{68}$ os ossos - se acaso estes chegarem até à tua mesa — tal qual os cães, ou lambendo uma folha seca de malva guarnecida com qualquer coisa, se é que esta foi desprezada pelos que estavam nas primeiras mesas, mas que a fome te fez devorar todo contente.

E nem falta uma outra forma de ultraje, pois és o único que não tem um ovo [só para si] — de facto, não é obrigatório que tu recebas o mesmo tratamento que os hóspedes ou os estranhos, pois isso seria uma estupidez — nem a tua galinha é igual às outras galinhas, pois a do teu vizinho é gorda e carnuda, ao passo que a ti dão-te metade de um frango ou um pombo já ressequido: ultraje claro e falta de consideração.

Não raro, se se verifica uma insuficiência [de comida] pelo facto de repentinamente se apresentar outro conviva, um criado retira os pratos que te estavam destinados e coloca-os diante do outro, sussurrando: "Tu és cá da casa." E no caso de trincharem sobre a mesa vísceras de porco ou uma peça de veado, tens, dê lá por onde der, de conseguir a simpatia daquele que faz a distribuição, ou então ganhar a parte de Prometeu ${ }^{69}$, ou seja, os ossos escondidos por debaixo da gordura. O facto de fazer passas ao vizinho que está antes de ti uma travessa, até que ele se farte de se atafulhar, enquanto à tua frente a travessa passa muito rapidamente, que homem livre poderia suportar

68 "roendo" ... "lambendo": O texto grego tem um só verbo, periesthío ( $\pi \varepsilon \rho \imath \varepsilon \sigma \theta i \omega)$ "comer à volta", que resolvi desdobrar, de acordo com o sentido mais adequado em português.

${ }^{69}$ Prometeu, filho do Titã Jápeto, foi um benfeitor da Humanidade e um mártir, precisamente pelo facto de Zeus achar que ele ia demasiado longe. No caso acima aludido, Prometeu dividiu um boi em dois quinhóes: um com a carne e as vísceras, que cobriu com a pele do animal, e o outro com os ossos envolvidos em gordura, após o que pediu a Zeus que escolhesse um dos quinhóes, deixando o outro para os homens. Zeus, iludido pela aparência, escolheu aquilo que logo verificou serem só ossos. Irritado com Prometeu, decidiu castigar os homens, retirando-lhes o fogo... mas Prometeu, incondicional filantropo, roubou o fogo de Zeus... ... 
tal coisa, mesmo que tivesse uma ira de veado ${ }^{70}$ E no entanto, ainda não referi mais uma coisa: enquanto os outros bebem um vinho delicioso e velhíssimo, tu és o único que bebe um vinho grosseiro e espesso, pelo que fazes por bebê-lo em taças de ouro ou de prata, para que não se veja, pela cor, que tu és um conviva desconsiderado. E mesmo que desse [vinho] queiras beber à tua vontade, depois de pedires insistentemente, o criado

| fingia não te escutar ${ }^{71}$.

27. Muitas coisas juntas, ou melhor, quase todas, te aborrecem, especialmente quando és ultrapassado por um qualquer debochado, ou um mestre de dança, ou um anão de Alexandria a cantar poemas jónicos ${ }^{72}$. Sim, como podes tu comparar-te com os que servem esses poemas eróticos e com os que trazem uns escritinhos debaixo da roupa? Por isso, como é natural, tu, reclinado num canto obscuro da sala e encolhido de vergonha, gemes, lamentas-te e acusas a Fortuna por nâo te ter distribuído nem um pouquinho sequer dos seus favores. Até me parece que terias maior gosto em ser poeta de cantos eróticos, ou [pelo menos] seres capaz de cantar dignamente os poemas de outros, ao veres até que ponto eles são estimados e aplaudidos, e até cederias, se tivesses de fazer o papel de mágico ou de um daqueles adivinhos que prometem heranças de muitos talentos ${ }^{73}$, grandes cargos e montes de riquezas. Realmente, bem vês como esses fulanos se dão bem com as suas amizades e são altamente considerados. Então aceitarias de bom grado uma dessas actividades, só para não te sentires um ser desprezível e inútil. Todavia, ó desventurado, não és nada convincente para esses ofícios. Portanto, é

${ }^{70}$ Em vez de traduzir à letra, poderíamos dizer "mesmo que fosse manso como um cordeirinho", "por muito pacífico que fosse".

${ }^{71}$ Iliada, XXIII, 430, mas num contexto muito diferente.

72 "poemas jónicos" sáo, aqui concretamente, poemas eróticos, declamados ou (como aqui: v. infra) cantados, mais ou menos "picantes", de autores como Anacreonte, Sótades, etc.

${ }^{73} \mathrm{O}$ talento não era uma moeda propriamente dita, mas uma «moeda de conto" (cf. contos de réis) = 60 minas; uma mina = 100 dracmas; uma $\mathrm{dracma}=6$ óbolos. Portanto, um talento $=6000 \mathrm{dracmas}$. O termo talento podia referir-se, de maneira indeterminada, àquilo que designamos por "um balúrdio». 
inevitável que continues a ser humilhado e aguentes em silêncio, gemendo baixinho e desprezado.

28. Se acaso algum criado maldizente te acusar de seres o único que náo elogia o rapazinho [querido] da senhora, quando ele dança ou toca cítara, corres, por esse facto, um risco nada insignificante. Portanto, deves grasnar como uma rã sequiosa em terra seca, a ponto de sobressaíres no meio dos aplaudintes, fazendo de corifeu. Muitas vezes, enquanto os outros estáo calados, [deves] lançar um elogio, já antes preparado, que revelará bem a tua bajulação.

$\mathrm{Na}$ verdade, o facto de um assalariado, faminto e sequioso, estar perfumado com mirra e ter uma coroa [de flores] na cabeça, é, por Zeus!, uma coisa completamente caricata. Sim, pareces-te com uma coluna funerária de um morto da véspera, ao qual vão celebrar-se sacrifícios: aspergem-na com mirra e colocam-lhe uma coroa [de flores], mas os ofertantes é que bebem e se regalam com a comida que prepararam.

29. E se o senhor é um tipo ciumento e tem filhos formosos ${ }^{74}$ ou uma jovem esposa, e se [além disso] tu náo fores completamente estranho a Afrodite e às Graças, ${ }^{75}$, a vossa relação não será pacífica, nem será desprezável o risco [que corres]: é que os ouvidos e os olhos do rei $^{76}$ são muitos, e não vêem só a verdade, mas acrescentam sempre alguma coisa mais, para que náo pareçam negligentes. Portanto, tal como nos jantares dos Persas, deves estar sempre de cabeça baixa, com receio de que um qualquer eunuco te surpreenda a olhar para uma das concubinas, enquanto um outro eunuco, com o arco tenso desde há muito, pronto, se tu vês o que não é permitido [ver], para te punir, varando-te as bochechas com uma flecha, exactamente enquanto tu estás a beber.

74 "filhos formosos" ou, também possível, "formosos rapazinhos". A primeira interpretaçáo parece preferível, pelo facto de, a seguir, mencionar a sua "jovem esposa": de uns e outra o seu empregado podia agradar-se... Claro que náo é de excluir (embora menos provável) uma referência a jovenzinhos fora da família...

75 "estranho a Afrodite" quer dizer "indiferente ao amor"; “(estranho) às Graças” significa "sem beleza”...

76 "os ouvidos e os olhos do rei": Trata-se, na frase comum, do rei da Pérsia, mas aqui faz-se referência ao senhor, o qual, tal como o rei da Pérsia, tem muitos informadores. 
30. Depois, sais da sala de jantar e vais dormir um pouquito, mas logo, acordado pelo canto do galo, exclamas: "Ó infeliz de mim! Ó desgraçado! Quantas antigas ocupaçōes deixei, quantos amigos, que vida despreocupada, que sono medido [somente] pelo meu desejo, que passeios livres, e em que precipicio acabo de me lançar! Mas porquê, ó deuses!? Que brilhante salário é este? Não seria possivel arranjar outro modo de vida melhor que este, conservando a minha liberdade e uma completa independência? Agora, porém, como sói dizer-se, como um leáo preso pela trela, sou arrastado para cima e para baixo, e, o mais lamentável de tudo, sem saber fazer-me estimar e sem ser capaz de me tornar agradável. Sim, sou um leigo naquelas actividades, sem qualquer habilidade, especialmente quando me comparo com pessoas que adquiriram um oficio, de modo que sou desengraçado e um conviva pouquissimo recomendável, incapaz de provocar o riso. Muitas vezes, basta [o patrão] olhar para mim, para eu perceber que estou a incomodá-lo, especialmente quando ele se esforça por ser mais simpático do que é habitual. Então ele acha-me muito acanhado." ". Em suma, não tenho maneira de me adaptar a ele. De facto, se me mantenho com um ar grave, pareço desagradável, é quase de fugir de mim; e se sorrio e componho um rosto o mais agradável possivel, ele mostra desprezo e cospe para $o$ chão ${ }^{78}$. Creio que é uma situação parecida com a de alguém que representasse uma comédia, mas com uma máscara trágica. Em suma - que insensato! - , que outra vida irei eu viver para mim próprio, depois de ter vivido a presente vida para outro?"

31. Enquanto reflectes sobre isto, toca a sineta ${ }^{79}$, e então há que cumprir a rotina, andar de um lado para o outro, ficar de pé, pelo que deves previamente friccionar as virilhas ${ }^{80}$ e os joelhos, se

${ }^{77}$ Os editores apresentam diferentes leituras, p. ex.: "Muitas vezes, basta olharem para mim, para eu perceber que estou a incomodar [os convivas], especialmente quando me esforço por ser mais simpático do que é habitual. Então pareço ainda mais acanhado."

${ }^{78}$ Cuspir (ou escarrar) para o chão é um gesto de grande desconsideração pela outra pessoa.

${ }^{79}$ No início do $\$ 30$, vemos o infeliz a ser acordado do seu breve sono pelo canto do galo; é então que produz esta sentida lamentação, interrompida pelo tocar da campainha, a chamar o pessoal da casa para as suas ocupaçôes diárias.

80 "virilha(s)": O editor da "Loeb" traduz por loins "lombo", "(zona dos) rins”, mas "virilhas” é o sentido que os dicionários dão a boubôn ( $\beta$ ov $\beta \hat{\omega} v)$. 
queres aguentar a luta. Depois, é o jantar, sempre igual e sempre prolongado até à mesma hora. Ora, estes hábitos, contrários ao teu antigo modo de vida, mais as vigílias, o suor e as canseiras vão-te minando pouco a pouco, causando a tísica, ou a peripneumonia ${ }^{81}$, ou a dor de barriga, ou a 'bela's2 gota. Tu, porém, resistes e, muitas vezes, quando deverias estar deitado, nem isso te é permitido, pois a tua doença é vista como um pretexto para fugires aos teus deveres. Por isso andas sempre muito pálido, com todo o aspecto de quem vai morrer a qualquer momento.

32. Isto é o que se passa na cidade. Mas se porventura há que viajar, muitas vezes, no caso de estar a chover (para já náo falar de outras coisas), como és o último a partir, és excluído da carruagem e tens de esperar, até que, por já não haver aí lugar, pregam contigo ao lado do cozinheiro ou do cabeleireiro da senhora, sem ao menos porem palha com abundância.

33. Não quero deixar de te contar um caso que me contou o meu amigo Tesmópolis, o estóico, acontecido com ele, [caso] muito engraçado e, por Zeus!, náo impossível de acontecer a qualquer outra pessoa. De facto, ele vivia em casa de uma certa mulher muito rica e muito sensual, das mais distintas da cidade. Ora, um dia em que precisaram de viajar, diz ele que suportou, logo de começo, uma situação muitíssimo caricata, que foi fazerem-no sentar — a ele, um filósofo - ao lado de um maricas de pernas depiladas e de barba toda rapada, que a senhora, obviamente, tinha em grande estima. [Tesmópolis] referiu mesmo o seu nome: chamava-se Quelidónio ${ }^{83}$. Desde logo, que coisa mais esquisita, esta de estar sentado ao lado de um homem velho e carrancudo, de barbas grisalhas — tu sabes como Tesmópolis tinha uma barba farfalhuda e venerável —, um sujeito com as faces besuntadas de rouge e com os olhos inferior-

81 “peripneumonia” é mesmo o vocábulo gr. peripneumonía ( $\pi \varepsilon \rho \mathrm{\imath} \pi$ -


peripneumonia bovina!

82 "bela": parece óbvio o sentido irónico.

${ }^{83}$ o gr. khelidónion ( $\chi \varepsilon \lambda_{\imath} \delta$ óvıov) é um diminutivo-hipocorístico de khelidóón $(\chi \varepsilon \lambda \imath \delta \omega ́ v)$ "andorinha". O homem chamava-se, pois "pequena (ou querida) Andorinha”. Este tipo de diminutivos-hipocorísticos em -ion, -idion, -árion... eram muito frequentes aplicados sobretudo a prostitutas, mas também a rapazes delicadinhos... Algumas linhas abaixo, faz-se um jogo com o sentido literal do nome da personagem: Andorinha e andorinha. 
mente pintados, de olhar inconstante e pescoço escanzelado, já não uma 'andorinha', mas, por Zeus!, um [autêntico] abutre [de pescoço] pelado ${ }^{84}$. Se náo o tivessem admoestado por diversas vezes, ele ter-se-ia sentado com uma touca ${ }^{85}$ na cabeça. Além do mais, durante toda a viagem provocou mil e uma situaçóes desagradáveis, cantarolando e assobiando; e se o filósofo não o tivesse impedido, talvez dançasse dentro da carruagem.

34. Então é-lhe dada uma outra ordem, do género desta: A senhora chama-o e diz-lhe: "Tesmópolis, tem a bondade de me fazer um favor nada pequeno que eu te peço, não mo recuses nem esperes que eu insista no meu pedido." E tendo ele. como é natural, prometido fazer tudo, diz a senhora: "Ao ver que tu és tão prestável, tão cuidadoso e tão carinhoso, peço-te que leves para a carruagem esta cachorrinha, que tu bem conheces, a Mirrina ${ }^{86}$, que a guardes por mim e cuides de que nada lhe falte, pois a coitadinha tem a barriga pesada e está prestes a dar à luz. Durante as viagens, estes criados malditos e desobedientes não fazem caso nenhum de mim, quanto mais dela. Por isso, não julgues que é pequeno o favor que me fazes, ao cuidares desta minha cachorrinha tão querida e tão deliciosa. "Tesmópolis prometeu fazer o que a senhora lhe suplicava insistentemente e quase em lágrimas. A cena era completamente cómica, com a cachorrinha a espreitar por fora do manto e por debaixo da barba [do filósofo], e constantemente a urinar (embora Tesmópolis não acrescente este facto), ganindo com voz esganiçada - como fazem as cachorrinhas de Malta ${ }^{87}$ — e lambendo a barba do filósofo, principalmente nas partes em que havia algum resto do molho da véspera. Um dia, o maricas que estivera sentado ao seu lado, escarnecendo dele diante dos outros convivas, aliás com certa graça, lançou este sarcasmo contra Tesmópolis: “ $A$

${ }^{84}$ Os manuscritos têm uma lição algo confusa, que os editores modernos tentam emendar. Esta interpretação pareceu-me mais consentânea com o contexto: pescoço escanzelado do jovem e pescoço pelado do abutre.

85 Trata-se de um atavio propriamente feminino. Percebe-se a figura que faria, a compor todo o quadro...

86 "Mírrina": É esta a forma correcta, esdrúxula e não grave, segundo a regra que manda acentuar, em latim, e, dai, em português, na antepenúltima sílaba as palavras gregas adaptadas, em que a penúltima sílaba é breve,

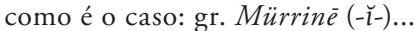

${ }^{87}$ Os minúsculos cachorrinhos de Malta estavam na moda entre as matronas e meninas da sociedade romana... Nada de novo... 
respeito de Tesmópolis, só tenho uma crítica a fazer: passou de estóico a... cínico. ${ }^{88}$ ". Fui até informado de que a cachorrinha havia dado à luz no manto de Tesmópolis.

35. É assim que eles se divertem, ou melhor, que ultrajam os que os servem, e assim os tornam, a pouco e pouco, dóceis aos seus ultrajes. Sei de um orador, daqueles de língua afiada, que, durante um jantar, instado [pelos convivas], pronunciou uma declamação ${ }^{89}$ num estilo nada grosseiro, mas sim, por Zeus!, muito claro e conciso. Era elogiado enquanto [os convivas] bebiam, pelo que o [tempo do] discurso foi medido, não pela água [da clepsidra $]^{90}$, mas pelas ânforas de vinho. Diz-se que a façanha lhe valeu duzentas dracmas.

Talvez isto ainda seja o menos mau. Mas se o ricaço for dado à poesia ou à prosa ${ }^{91}$, e se, durante o jantar, declamar as suas obras, então tens de te esgatanhar todo em elogios e adulação, inventando novas formas de louvor. Outros há, que pretendem ser admirados pela sua beleza, e então há que tratá-los por uns Adónis, ou uns Jacintos, mesmo que eles tenham, por vezes, um nariz de palmo e meio ${ }^{92}$. E se tu não os elogiares, serás imediatamente lançado às pedreiras de Dionísio ${ }^{93}$, como invejoso e conspirador. É preciso que eles sejam [considerados] sábios e oradores, e, mesmo que aconteça cometerem algum solecismo, isso deve ser visto como discursos recheados de

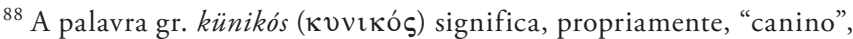
mas também serviu para designar os filósofos... "caninos" ou "cínicos". Claro que esta conotação só é directamente perceptível em grego.

89 "pronunciar uma declamação" ou "declamar”, gr. meletáo ( $\mu \varepsilon \lambda \varepsilon \tau \alpha \dot{\alpha} \omega)$ : refere-se aos exercícios práticos de retórica, sujeitos a um tema, que o orador ou o estudante desenvolvia com o máximo de aparato possível. Os romanos chamavam a estes exercícios declamationes.

${ }^{90}$ Os oradores dispunham de um tempo previamente marcado: uma clepsidra, duas clepsidras...

91 "dado à poesia ou à prosa": O texto não diz que o homem é poeta ou prosador, mas emprega dois adjectivos, que traduzi por "dado a...". Nota-se a vaidade do senhor, que pretende fazer de erudito, sem ter grande queda para isso, mas também sem ter quem lhe diga a verdade...

92 O texto diz "um nariz de um côvado". O côvado equivale, com a precisão possível, a $0,444 \mathrm{~m}$; como, porém, aqui se trata de um valor meramente sugestivo, traduzi por "um nariz de palmo e meio"...

93 Dionísio, tirano de Siracusa; as suas pedreiras eram um lugar de "trabalhos forçados", pena a que muitos eram condenados. É óbvio que, aqui, a referência tem valor figurado... 
aticismo $^{94}$ e de [mel do] Himeto, e daí em diante passa a ser norma falar desse modo.

36. Ainda assim, talvez isso ainda seja tolerável no caso dos homens. As mulheres, porém... sim, é uma coisa muito desejada também pelas mulheres, terem junto delas, assalariados, uns quantos homens cultos que seguem atrás da liteira. De facto, consideram isto, entre outros, um dos seus ornamentos ${ }^{95}$, ou seja, que se diga que elas são mulheres cultas, filósofas ${ }^{96}$, e que compóem cantos que não ficam a dever muito aos de $\mathrm{Safo}^{97}$. Por isso, fazem-se rodear de mestres de Retórica, gramáticos e filósofos, todos assalariados, e escutam as suas lições... sabes quando? - Que coisa tão cómica! - ... enquanto lhes fazem a toilette, lhes entrançam os cabelos ou durante as refeições ${ }^{98}$, pois a outra hora náo têm vagar. Muitas vezes, enquanto o filósofo disserta, entra a criadita, que lhe entrega um bilhetinho do amante. Então, cessa todo aquele arrazoado a respeito da continência, esperando até que ela responda ao amante, para [só depois] regressar a audição ${ }^{99}$.

${ }^{94}$ No tempo de Luciano surgiu a corrente linguístico-literária chamada Neo-aticismo, que pretendia restaurar o grego dos tempos áureos da Atenas clássica.

${ }^{95}$ A palavra (pl.) kallōpismata ( $\left.\kappa \alpha \lambda \lambda \omega \pi i \sigma \mu \alpha \tau \alpha\right)$ "ornamentos", refere-se, propriamente, a jóias; aqui o sentido é mais extenso: a companhia de pessoas cultas é mais um ornamento a juntar aos outros...

96 "filósofas": Em gr., o vocábulo philósophos ( priamente, um adjectivo biforme (masc.-fem.:-os; neutro: -on). Como substantivo, era, inicialmente, "propriedade dos homens"; ao ser aplicado a uma mulher (coisa horrível, mas também rara), conservou a forma do masculino. Note-se que a tradução port. filósofa suscita alguma resistência...

97 Safo, a maior poetisa grega, tinha todos os atributos literários e temáticos para ser admirada pelas mulheres cultas.

98 "durante as refeiçóes": O texto gr. diz "durante o jantar", mas o vocábulo deîpnon ( $\delta \varepsilon \hat{\imath} \pi$ vov) tem uma extensão temporal muito incómoda para quem traduz, podendo significar (v. dicionários) "refeição" (em geral), "almoço", "jantar", "ceia”. Neste caso, náo deve tratar-se da refeição da manhã, pois um pouco antes era o momento da toilette; entre "almoço" e “jantar”, é só escolher. Por isso traduzi por "durante as refeiçóes”.

99 Repare-se na dureza da censura: A “dona” interrompe a aula de filosofia, onde o mestre dissertava sobre a continência, precisamente para ler o bilhete do amante e, em seguida, responder-lhe, após o que regressa à aula de... moral... 
37. Quando, enfim, passado longo tempo, se aproximam as festas de Crono ${ }^{100}$ ou as Panateneias, é-te enviado um pobre manto ou uma túnica meio carcomida [do bicho], justamente no momento em que precisas de te apresentar com grande magnificência na procissáo. $\mathrm{O}$ primeiro [criado] que ouviu o senhor ainda só a pensar [em dar-te o presente], abala a correr para te avisar, assim recebendo pela notícia uma paga nada modesta. Logo de manhá, vêm treze ${ }^{101}$ criados trazer-te [o presente], cada um deles contando como havia feito muitos elogios [a teu respeito], como tinha sugerido [o teu nome], como, encarregado de o fazer, escolheu a [peça] mais bela. Deste modo, todos vão dali depois de receberem "algum", mas, ainda assim, murmurando por não lhes teres dado mais.

38. Quanto ao teu salário, propriamente ${ }^{102}$, vem aos dois ou quatro óbolos de cada vez; e se és tu a pedi-lo, passas por insuportável e importuno. E para conseguires receber, tens de adular o senhor e suplicar-lhe, ou então cortejar o ecónomo - esta é uma nova forma de servidão —; também não deves descurar o conselheiro ou um amigo [do senhor]. Além disso, o [dinheiro] que recebeste já estás a devê-lo ao alfaiate, ao médico ou a um qualquer sapateiro. Portanto, os presentes não são presentes, e de nada servem ${ }^{103}$.

39. Também é muita a inveja, e entẫo surge alguma calúnia, que é insidiosamente transmitida a um senhor já de si disposto a acolher de bom grado as palavras contra ti, pois de há uns tempos para cá vê-te esgotado pelas sucessivas canseiras, tardo e contrariado nas tuas obrigaçóes, e com a gota a avançar

${ }^{100}$ Crono, pai de Zeus, tinha a sua festa, em Atenas, entre Julho e Agosto; em Roma celebrava-se a festa do deus correspondente, Saturno, na $2^{\text {a }}$ metade de Dezembro: eram as Saturnais. As Panateneias eram a grande festa anual em honra de Atena; de quatro em quatro anos celebrava-se as Grandes Panateneias, com toda a magnificência. É natural que o nosso texto se refira à festa anual.

101 “treze” é, evidentemente, um "número indeterminado", que serve para exagerar para mais (como aqui) ou para menos. Em port., melhor diríamos "uma dúzia de criados”...

102 "propriamente" alude aos tais "presentes" que o senhor distribui pelas festas, e que náo haviam ficado no contrato.

103 "os presentes não são presentes, e de nada servem", citação alterada de Sófocles, Ajax, 665. 
insidiosamente. Numa palavra, depois de colher a flor mais saborosa e o fruto mais abundante da tua juventude, depois de destruir o teu enorme vigor físico, depois de ter feito de ti um trapo esfarrapado, ei-lo que olha à sua volta, a ver em que parte da estrumeira te há-de lançar e que outro há-de contratar, de entre os que sejam capazes de aguentar as canseiras. Então, acusado de teres alguma vez assediado um rapazinho querido ${ }^{104}$ do senhor, ou de, mesmo velho, quereres seduzir a criadita [privada] da senhora, ou de qualquer outro delito, eis que, em plena noite, de cara coberta ${ }^{105}$, és expulso da casa, agarrado pelo pescoço, privado de tudo, sem recursos, levando contigo e tua rica gota, acrescida da velhice, esquecido até, em todos esses anos, do que antes sabias, em que ganhaste uma barriga maior que um odre, maldito órgão insaciável e muito exigente. De facto, a goela exige a porção habitual e fica irritada se a desabituam.

40. Além disso, mais nenhum senhor te receberia, pois já estás passado da idade, mais parecido com aqueles cavalos muito velhos, cuja pele — nem mesmo essa - é aproveitável. Aliás, a calúnia pela qual foste expulso, pintada com grande exagero, faz que te considerem um adúltero, um envenenador ou qualquer coisa do género. $\mathrm{O}$ teu acusador, mesmo calado, é digno de todo o crédito, enquanto tu és um grego ${ }^{106}$, um tipo de carácter leviano e dado a [cometer] qualquer crime. De facto, as pessoas julgam que nós somos todos dessa laia; é natural que assim julguem, e eu até creio perceber o motivo por que eles têm esse conceito de nós. Na verdade, muitos dos que entraram nessas casas, por não possuírem nenhuma profissão útil, oferecem adivinhações, drogas, favores em matéria amorosa, encantamentos contra os inimigos e coisas do género, armados em homens cultos, assim envoltos em mantos e usando uma barba muito respeitável. É, pois, natural que as pessoas tenham sobre todos nós a mesma opiniāo, ao observarem aqueles que julgavam serem os melhores, especialmente ao verificarem a sua sabujice nos banquetes e na sua convivência, bem como o seu servilismo em relação ao lucro.

104 "rapazinho querido": O sentido de "querido" está no sufixo diminutivo-hipocorístico: meirák-ion ( $\mu \varepsilon \imath \rho \alpha ́ \alpha \iota \mathrm{ov})$; também poderá entender-se "rapazinho favorito", de qualquer maneira, com uma conotação erótica.

${ }^{105}$ Entenda-se que é o próprio a quem expulsam que cobre a cara, por vergonha, para que náo o reconheçam.

${ }_{106}$ Note o toque de xenofobia, bem explícito no período seguinte. 
41. Uma vez expulsos, [os senhores] passam a odiá-los, como é natural, e procuram por todos os meios possíveis destruí-los por completo, pois pensam que eles irão divulgar os muitos segredos do seu comportamento, como pessoas que os conhecem todos e que os viram completamente nus ${ }^{107}$. Esse pensamento sufoca-os. De facto, são todos exactamente iguais a esses belíssimos rolos [de papiro] cujos botóes [de fecho] são de oiro e cuja capa de pele é cor de púrpura, mas que lá dentro contêm Tiestes a comer os próprios filhos ${ }^{108}$, Orestes a desposar a mãe ou Tereu a ter relaçóes com duas irmấs ${ }^{109}$. Tais são esses [senhores], brilhantes e admiráveis, mas por debaixo da púrpura escondem muita tragédia. Se desenrolares ${ }^{110}$ cada um deles, acharás um drama nada pequeno de Eurípides ou de Sófocles, enquanto a capa é cor de púrpura florida e o botão [de fecho] é de oiro. Portanto, conscientes disso, odeiam e tentam tramar todo aquele que, tendo-se afastado, e por os conhecer muito bem, irá divulgar a história e contá-la a muita gente.

42. Quero, porém, à semelhança do famoso Cebes ${ }^{111}$, pintar-te um quadro de uma tal vida, a fim de que tu, ao vê-lo, saibas se deves [ou não] entrar nele. Antes de mais, muito gostaria de possuir a $\operatorname{arte}^{112}$ de um Apeles, de um Parrásio. de um Aécion ou de um Eufranor. Como, porém, hoje em dia é muito difícil

107 "completamente nus" pode não ter sentido literal, mas significar "exactamente como eles são por dentro"... mas, dado o contexto, o sentido literal não é de excluir.

${ }^{108}$ Fulcro da história: Atreu matou os filhos de seu irmão Tiestes e deu-lhos a comer. Trata-se de um dos episódios mais cruéis da mitologia grega.

${ }^{109} \mathrm{Na}$ verdade, Tereu era casado com Procne, mas apaixonou-se pela irmã desta, Filomela, à qual, depois de consumado o acto, cortou a língua, para que não divulgasse o sucedido. A história tem outros aspectos macabros...

110 "desenrolares": Simultaneamente em sentido próprio (aplicado aos rolos de papiro) e em sentido figurado (os senhores).

${ }^{111}$ Cebes é uma personagem real, do tempo de Sócrates e Platão, mas a obra que lhe é atribuída, Pinax (Пív $\alpha \xi)$, “Quadro"(da vida humana), é muito mais tardia (séc. I d.C.). A descrição literária contém fortes alusōes pictóricas.

112 "arte", entenda-se pintura(Apeles, Parrásio) ou escultura (Aécion); Eufranor era pintor e escultor. 
encontrar alguém assim tão talentoso e tão rigoroso nessa arte, irei desenhar-te, o melhor possível, um quadro em simples prosa ${ }^{113}$.

Em primeiro lugar, imagina que está representado um pórtico muito alto, de ouro, não ao nível do chão, mas situado no alto de uma colina. A subida é muito longa, escarpada e escorregadia, de modo que, muitas vezes, as pessoas, esperando encontrar-se já quase no cimo, punham o pé em falso, despenhavam-se e quebravam o pescoço. Lá dentro, está sentado Pluto em pessoa, todo de oiro, segundo parece, muito formoso e muito amável. Então o seu apaixonado, depois de, a muito custo, chegar ao cimo, aproxima-se da porta e fica estupefacto ao ver tanto ouro. Depois, a Esperança, também ela de formosa figura e garridamente vestida, pega nele e introdu-lo no átrio, completamente mudo de espanto. Daí em diante, a Esperança segue sempre à sua frente, mas outras mulheres, a Fraude e a Servidão, recebem-no e entregam-no ao Trabalho, o qual, depois de ter bem massacrado o infeliz, acaba por entregá-lo nas mãos da Velhice, já adoentado e muito amarelento. Finalmente, a Insolência pega nele e atira-o ao Desespero. Quanto à Esperança, nunca mais se vê, partiu voando; e o desgraçado é posto fora, já não pelo pórtico dourado por onde havia entrado, mas, saindo por uma saída secundária e escondida, nu, barrigudo, pálido e velho, com a mão esquerda a tapar as vergonhas, e apertando o pescoço com a direita. Ao sair, vem ao seu encontro o Arrependimento, todo choroso, mas inutilmente, e fazendo coro de lamentaçóes com o desgraçado.

Assim termina o quadro. Agora tu, meu caro Tímocles, observa por ti próprio e cuidadosamente cada pormenor e pensa se te assenta bem o facto de, tendo entrado, no quadro, aqui por esta porta, acabares por sair vergonhosamente pela porta oposta. Qualquer que seja a tua decisão, lembra-te do que diz o sábio ${ }^{114}$ : "Deus não tem culpa; a responsabilidade é de quem decide."

${ }^{113}$ A descrição que se segue contém indicaçôes pictóricas muito sugestivas, que bem poderiam servir de "guiāo" para um pintor.

${ }^{114}$ Citação de Platão, A República, X, 617 e, mas na ordem inversa. 
APOLOGIA DOS ASSALARIADOS

DOS GRANDES 
(Página deixada propositadamente em branco) 


\section{INTRODUÇÁo}

Entre o panfleto Contra os Assalariados dos Grandes e a Apologia dos Assalariados dos Grandes decorrem muitos anos, que vão dos bons tempos em que Luciano amealhara (e continuava a amealhar) um confortável pecúlio ganho na sua actividade de advogado e professor de Retórica, até uma época em que, já "reformado" dessas actividades lucrativas, via o dinheiro a sumir-se inexoravelmente.

Então - "Pela boca morre o peixe" - , Luciano aceita (ou consegue?) um cargo de alto funcionário público na província imperial do Egipto, onde aufere um salário, segundo ele afirma, muito elevado, a que correspondem funçóes de grande prestígio, que o levam a pensar que, algum tempo depois, será nomeado para um cargo ainda mais alto, talvez mesmo o de praefectus Aegypti.

O pior é que ficara na memória de alguns dos seus amigos (e inimigos!) uma declamatio pronunciada anos atrás perante uma multidão de gente curiosa de assistir a um discurso de aparato, e logo publicada em muitos exemplares, em que Luciano se insurge contra certos intelectuais que se associam aos ricaços da Roma imperial, na qualidade de clientes, actividade que, na maior parte dos casos, resulta em mais trabalho que proveito, que chega mesmo a ser uma servidão indigna de um homem livre. É claro que essa declamatio tem uma finalidade sobretudo retórica, é o desenvolvimento de um tema que pode não interessar intimamente ao seu autor, mas que lhe serve de pretexto para patentear os seus dotes oratórios.

De qualquer maneira, quando Luciano se vê constrangido a enveredar pela carreira de funcionário público, ocorre-lhe à mente o "espinho" que constitui o panfleto dos bons velhos tempos. Quer dizer que o homem que antes criticara os que vendiam a sua liberdade, agora vê-se constrangido a aceitar um lugar no funcionalismo público. Inevitavelmente, vem-lhe à memória aquele escrito de outros tempos, em que sobranceiramente tenta desviar o seu amigo Tímocles de um modo de vida que ele abomina.

Por isso, ao mudar de vida, tenta justificar-se, não já perante o amigo Tímocles (já teria morrido?), mas perante um outro amigo, sem dúvida mais novo, Sabino, que não assistira 
ao espectáculo retórico contra os assalariados, mas que ouvira falar dele e do qual, de resto, possuía um exemplar escrito.

A Apologia dos Assalariados dos Grandes é bastante mais curta que o outro panfleto. Além do mais, parte do $\$ 1$ e os $\$ \$ 3-7$ contêm a argumentação e o discurso que Luciano presume serem, mais ou menos ipsis verbis, do seu amigo Sabino. Para a argumentação e discurso de defesa de Luciano ficam somente os $\$ \$ 8-15$. Entre os argumentos possíveis, os três primeiros são logo de rejeitar:

$\$ 8$ : O destino, contra o qual o ser humano nada pode;

\$9: O puro desejo de se juntar a pessoas importantes, não por dinheiro, mas pela nobreza de alma e inteligência;

$\$ 10$ : A velhice, a doença e a pobreza.

A verdadeira defesa da actividade assalariada pela qual Luciano enveredara consiste na nobreza das funçóes em prol da comunidade. Além disso, o salário auferido é muito elevado, mas, enfim, toda a gente trabalha na expectativa de obter algum lucro... a começar pelo Imperador. Trata-se, pois, de uma diferença de quantidade, que não de qualidade.

Por último - argumento bem comovente! - Luciano considera-se apenas "um dos muitos homens vulgares, que, de facto, exerceu a arte de falar e é razoavelmente elogiado por esse facto, mas que, no entanto, náo está muito treinado naquela extrema virtude dos corifeus [da Filosofia]. E, por Zeus!, não devo ficar aborrecido por esse facto, pois nunca encontrei ninguém que cumprisse plenamente as promessas do sábio" (\$15). 


\section{Apologia dos Assalariados dos Grandes}

1. Já desde há tempos ${ }^{115}$, meu caro Sabino, que ando a pensar comigo mesmo que palavras te ocorrem ao espírito, a ti, que leste o nosso ${ }^{116}$ livro [intitulado] Contra os Assalariados dos Grandes ${ }^{117}$. De facto, é para mim mais que evidente que não o lias sem te fartares de rir. No entanto, vou procurar conciliar os teus comentários, particulares e na generalidade, com o próprio texto que tu leste. Ora, a menos que eu seja muito mau em matéria de adivinhação, parece-me ouvir-te falar assim: "Então este fulano, que tais coisas escreveu e que desenvolveu uma acusação tão dura contra esse modo de vida, tempos depois, esquecido de tudo [quanto escreveu], 'logo que - como sói dizer-se - a sorte mudou'118, pega em si e lança-se numa escravidão tão evidente e à vista de toda a gente? Quantos Midas, Cresos e Pactolos ${ }^{119}$, todos juntos, o convenceram a abandonar a liberdade, sua querida companheira de infância, ele que já está mesmo à vista de Éaco ${ }^{120}$ e com um dos pés praticamente dentro da barca, e a oferecer-se para ser puxado e arrastado, preso como que por uma coleira de ouro no pescoço, tal e qual aqueles macaquinhos e saguins dos ricos efeminados? ${ }^{21}$. É, pois, enorme a diferença entre o seu modo de vida actual e este seu escrito.

115 "desde há tempos": O adv. pálai $(\pi \alpha \dot{\alpha} \lambda \mathrm{\iota})$ tanto pode significar "há (já) muito tempo", como "recentemente". Optei por uma expressão intermédia.

116 "nosso": Plural majestático = "meu".

117 Foi esta a minha tradução (não literal) do título da referida obra. Esta alusão mostra qual era realmente esse título, mais ou menos: "Sobre os que convivem [com os grandes] mediante salário"...

${ }^{118}$ A frase grega era ostrákou metapesóntos (ỏ $\left.\sigma \tau \rho \alpha ́ \alpha \kappa o v ~ \mu \varepsilon \tau \alpha \pi \varepsilon \sigma o ́ v \tau o \varsigma\right)$ ), "tendo a concha (ou o caco de cerâmica) caído do outro lado", ou seja, do lado mau (o negro ou mais escuro). Faz-se referência a um jogo parecido com o nosso de "cara ou coroa", ostrakinda paizein (ỏ $\sigma \tau \rho \alpha \kappa i ́ v \delta \alpha$ $\pi \alpha i \zeta \varepsilon \imath v)$, jogado como a "moeda ao ar".

119 Midas e Creso eram famosos pelas suas riquezas; Pactolo é uma personagem mitológica, que, na sequência de uma tragédia, se lançou numa ribeira aurífera, que depois foi rebaptizada com o nome do famoso suicida.

${ }^{120}$ Éaco é um dos juízes do reino dos mortos, o reino de Hades.

121 "tal e qual aqueles macaquinhos e saguins dos ricos efeminados".

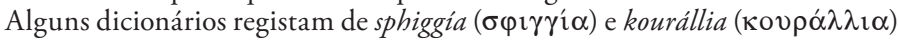
como duas espécies de macaquinhos de estimação. Outros dicionários e editores entendem como "pulseiras" e "colares", que estariam, metaforicamente, por "algemas" e "coleiras". Na verdade, este passo causa dificuldades a toda a gente... 
Dir-se-ia que os rios correm para cima, tudo está do avesso, com nova versão, mas para pior, não como aquela palinódia ${ }^{122}$ que foi escrita em favor de Helena e sobre o que aconteceu em Tróia, mas em termos verdadeiramente opostos aos que, na tua primitiva versão, pareciam ser usados muito justamente."

2. Foram estas, presumivelmente, as palavras que tu pronunciaste para contigo mesmo. E é possível que acrescentes algum conselho dirigido à minha pessoa, conselho nada despropositado, mas sim de amigo e próprio de um homem como tu, um honesto filósofo. Ora, se eu puser a tua máscara e representar convenientemente [o teu papel ${ }^{123}$, tudo bem para nós, e nesse caso ofereceremos um sacrifício ao Eloquente ${ }^{124}$. Caso contrário, tu acrescentarás o que faltar. Portanto, é tempo de mudarmos a cena, tempo de eu me manter silencioso e deixar que me retalhem e me queimem, se isso for necessário à minha salvação, e de tu me aplicares os teus medicamentos, de teres pronto o bisturi e o ferro aquecido ao rubro. Pois entáo, ó Sabino, toma a palavra e pronuncia imediatamente o discurso seguinte dirigido à minha pessoa ${ }^{125}$ :

3. "Meu querido amigo, esta tua obra foi outrora muito gabada, como seria natural, não só quando foi declamada ${ }^{126}$ perante uma

122 "palinódia” ou retractação. Alude-se ao poeta Estesícoro, que escreveu coisas muitos infamantes a respeito de Helena, pelo que Zeus o puniu, privando-o da vista. Então o poeta voltou a escrever sobre o mesmo tema, mas agora nos termos mais elogiosos em relaçáo a Helena. No caso de Luciano, deu-se o inverso: a retractação, ou palinódia, foi no pior sentido.

123 "máscara”... "papel”: O texto grego tem uma única palavra, prósōpon $(\pi \rho o ́ \sigma \omega \pi \mathrm{ov})$, que tem os dois sentidos "fundidos", mas que entendi desdobrar, por conveniência de tradução.

124 "Eloquente" é, pelo menos aqui, o deus Hermes, que tinha outros atributos: "psicopompo" (condutor das almas dos mortos), deus do comércio, patrono dos ladróes, etc. Em vez de "Eloquente", eu diria antes "Palavroso". Em todo o caso, não me parece aceitável a tradução da "Loeb" por "God of Reason", pois, neste contexto, Lógios refere-se a lógos no óbvio sentido de "discurso".

${ }^{125}$ Note o longo discurso (\$\$3-7) que Luciano póe na boca de Sabino.

${ }^{126}$ A obra Contra os Assalariados dos Grandes foi primeiramente pronunciada numa "declamação", como era uso fazer-se, perante uma audiência apreciadora de discursos "farfalhudos", sobre temas muitas vezes inesperados e até mesmo incríveis. A seguir à declamação, o folheto era publicado e passava para o domínio público "permanente". Este amigo de 
grande multidão, conforme me contaram os que então assistiram a essa declamação, mas também entre todos os eruditos que quiseram conhecê-la e tê-la entre mãos. Realmente, a escolha das palavras é irrepreensivel, a narração é ampla, grande a experiência da vida, cada pormenor é exposto com a máxima clareza, $e-o$ mais importante de tudo - era uma obra muitissimo útil a toda a gente, mas de modo especial para os homens cultos, a fim de, por imprudência, não se lançarem na escravidão. Como, porém, mudaste de ideias e achas ${ }^{127}$ que assim é melhor, [ou seja,] dizer adeus para sempre à liberdade e adoptar aquele ignóbil iambo:

\section{'Em troca de grande lucro | sê servo contra natura'128,}

tem cuidado, que de agora em diante ninguém te oiça ler essa obra, e nem sequer permitas que o texto chegue a nenhum dos que vêem o teu modo de vida actual, mas suplica antes a Hermes Ctónio ${ }^{129}$ que espalhe muita água do Lete sobre aqueles que outrora te ouviram, pois, caso contrário, parecerá que te aconteceu aquela história do corintio ${ }^{130}$, e que, como outro Belerofonte, escreveste o livro contra ti próprio. De facto, por Zeus!, não vejo que defesa especiosa poderias apresentar contra os que te acusam, especialmente se eles se eles agem no meio de risota, elogiando, por um lado, a obra escrita e a liberdade nela contida, mas vendo, por outro lado, o próprio autor a servir como escravo e a submeter voluntariamente o pescoço ao jugo.

Luciano, Sabino, não assistira ao "espectáculo" ao vivo, mas ouvira falar do assunto e, sobretudo, tinha diante de si o livrinho (o rolo).

127 "mudaste de ideias e achas": no texto grego, é um só verbo, metadokéo ( $\mu \varepsilon \tau \alpha \delta \circ \kappa \varepsilon \dot{\varepsilon} \omega)$, que poderíamos traduzir por "Como, porém, agora já achas que é melhor...”.

${ }_{128}$ Eurípides, Fenicias, 398.

129 "Hermes Ctónio", ou seja, "H. Subterrâneo": A ligação de Hermes ao reino subterrâneo, ao reino dos mortos deve-se ao facto de este deus ser "condutor de almas", psükhopompós ( $\psi \vee \chi 0 \pi \mathrm{O} \mu \pi$ ó $\varsigma$ ). A seguir refere-se o rio Lete, ou rio do esquecimento, que apagava a memória dos tempos vividos sobre a terra, e aqui, a memória em geral.

${ }^{130}$ Este coríntio é Belerofonte (a seguir mencionado). Eis a parte da

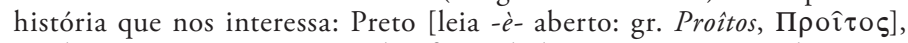
rei de Tirinto, encarregou Belerofonte de levar uma carta a Ióbates, rei da Lídia, na qual se pedia a este que matasse o portador... o que acabou por não acontecer... 
4. Não deixaria, pelo menos, de ser razoável que eles assim falassem, se dissessem que o livro era da autoria de um outro, um nobre homem, e que tu, como o gaio, te enfeitaste com penas alheias ${ }^{131}$; ou então, se a obra é da tua autoria, tu procedes da mesma maneira que Saleto, o qual, tendo feito para os Crotoniatas uma lei durissima contra os adúlteros, pela qual foi muito admirado, passado pouco tempo foi surpreendido em adultério com a mulher de seu irmáo. Poderiamos, pois, afirmar que o teu caso é exactamente como o de Saleto; todavia, o caso deste era muito mais desculpável, por um lado, por se ter deixado dominar pela paixáo, como ele próprio confessou no seu discurso de defesa, e, por outro lado, por se ter lançado voluntária e corajosamente na fogueira ${ }^{132}$, apesar de os crotoniatas se terem apiedado dele e lhe terem permitido exilar-se, se assim o desejasse. O teu comportamento, porém, não é menos absurdo, pois, na tua obra, descreves com toda a minúcia a escravidão desse modo de vida e censuras todo aquele que, tendo caído em casa de um rico e tendo-se ai encarcerado, se resigna a sofrer e a praticar mil e um actos penosos, e que, na extrema velhice e já quase na soleira [da morte], assume uma servidão tão ignóbil e quase se vangloria dela. Ora, quanto mais emproado te apresentares aos olhos dos outros, mais ridiculo parecerás, por contraste entre a tua vida actual e o teu livro.

5. Mas para que preciso eu de procurar uma nova acusação contra ti, depois dessa admirável tragédia, onde se diz que

'tenho ódio ao sofista | que só pra si não é sábio'?133

Os teus acusadores não terão falta de outros exemplos contra ti, pois uns comparar-te-ão aos actores trágicos, os quais, em cena, são Agamémnon, ou Creonte, ou o próprio Héracles, ao passo que fora [de cena], e tirada a máscara, tornam-se Polo, ou Aristodemo, que representam por dinheiro, que são escorraçados ${ }^{134} e$ assobiados, $e$ alguns deles até mesmo chicoteados, se assim o decidir a assistência. Outros diráo que te aconteceu o mesmo que ao macaco que,

131 "penas alheias": A fábula especifica: "penas de pavão".

132 Parece-me poder deduzir que o castigo que o legislador Saleto impunha aos adúlteros era a morte na fogueira, punição que ele impôs a si próprio.

${ }_{133}$ Citação de Eurípides, fragmento de tragédia perdida.

134 "escorraçados", entenda-se: por se enganarem... 
segundo se diz, pertencia à famosa Cleópatra. De facto, este animal tinha sido ensinado a dançar muito elegantemente e a compasso, sendo muito admirado por manter a compostura e observar a gravidade, dançando em conformidade com os que cantavam e tocavam o himeneu ${ }^{135}$. Ora, uma vez, tendo avistado uma passa de figo, julgo eu, ou uma amêndoa caída no chão, disse adeus às flautas, aos ritmos e às danças, e, mandando fora a máscara, ou melhor, desfazendo-a, deitou a mão ao fruto e devorou-o.

6. $T u^{136}$, porém - diriam [os teus acusadores] —, que não és um actor, mas que te tornaste um autor das mais belas obras e um jurista, bastou que te surgisse esta [espécie de] passa de figo, para te revelares como um [autêntico] macaco, filósofo da boca para fora, 'uma coisa escondendo no coração, mas dizendo outra coisa'137. Seria justo dizer contra ti que essas palavras que dizes e pelas quais te julgas digno de ser elogiado

\section{'teus lábios humedeceram, | mas ficou seco o palato'138.}

Deste modo, não tardou a seres punido ${ }^{139}$ por te insurgires tão insolentemente contra as necessidades das pessoas, pois, passado pouco tempo, abjuraste da tua liberdade, como que tuc $^{140}$ pela voz de pregoeiros. Até parecia que Adrasteia ${ }^{141}$, de pé por detrás de ti quando tu estavas a ser aplaudido pelas tuas acusaçóes contra os outros, se deixava rir, conhecedora, como deusa que era, da tua mudança futura, igual à desses homens, e [notando] que tu, sem

135 O himeneu: canto, música e dança nupciais.

${ }^{136} \mathrm{Na}$ ed. "Loeb”, o $\$ 6$ começa um pouco adiante, em pleno texto, que não me deu jeito interromper para intercalar a indicação de novo parágrafo.

137 Paráfrase de Homero, Iliada, IX, 313.

${ }^{138}$ Iliada, XXII, 495, já citado em Contra os Assalariados dos Grandes, $\$ 20$.

139 "não tardou a seres punido", e, logo a seguir, "passado pouco tempo" parecem apontar para a proximidade temporal das duas obras, o que é desmentido por outros passos, que situam o panfleto Contra os Assalariados dos Grandes numa fase relativamente recuada da vida de Luciano. Por isso, há que entender aquelas duas frases em sentido um tanto vago.

140 "como que" aponta para uma expressão figurada, como se Luciano fosse posto à venda, como escravo, apregoado por um pregoeiro...

141 "Adrasteia", outro nome de Némesis, deusa da vingança. A forma port. assenta na forma lat. Adrastēa; em port., a sequência -ea evolve para -eia, cf. lat. vèna-> port. arc. vea > veia; correa > correia, etc. Note-se que outra forma latina, Adrastīa, daria em port. *Adrastia. Fiquemos por aqui... 
primeiro cuspires para dentro do manto ${ }^{142}$, te atrevias a censurar aqueles que, por diversas vicissitudes do destino, se viam constrangidos a tomar esse modo de vida.

7. Ora ${ }^{143}$, se alguém desse àquela tua obra este titulo ${ }^{144}$ : 'Ésquines, após a discurso de acusação contra Timarco ${ }^{145}$, é ele próprio apanhado e surpreendido a cometer o mesmo crime', que risota julgas tu que se levantaria da parte da assistência, se o acusador culpasse Timarco pelos seus pecados de juventude, ao passo que ele, Esquines, tinha cometido os mesmos crimes, mas já velho?! Em resumo, és tal e qual aquele vendedor de medicamentos, que apregoa um remédio contra a tosse e promete aliviar imediatamente os pacientes, enquanto ele próprio parece rebentar com ataques de tosse".

8. São estas e muitas outras as coisas que poderia dizer um acusador como tu, em assunto tão vasto e capaz de gerar enorme quantidade de argumentos. Mas agora estou a pensar que argumentação deverei orientar em minha defesa. Não seria melhor para mim acobardar-me, virar as costas e não negar ter procedido mal, e refugiar-me naquela defesa habitual, ou seja, [alegando] a Sorte, a Parca e o Destino, e pedir aos meus censores que me desculpassem, atendendo a que nós não somos senhores de nada, mas, pelo contrário, somos arrastados, contra a nossa vontade, por alguma entidade superior, nomeadamente uma das acima mencionadas, pelo que somos completamente inocentes em relação ao que dizemos ou fazemos? É claro que isso seria absolutamente vulgar, e tu, meu querido amigo, não permitirias que eu avançasse com uma tal defesa e, tomando Homero por meu advogado, declamasse estes seus versos

\section{Digo-te que nenhum homem | jamais fugiu ao se Fado ${ }^{146}$,}

${ }^{142}$ Mandava a superstição que, para esconjurar a punição de Némesis, havia que cuspir três vezes no manto (lagarto, lagarto, lagarto! — diríamos hoje)... o que Luciano não terá feito.

${ }^{143}$ A ed. "Loeb" insere o $\$ 7$ umas linhas adiante.

${ }^{144}$ Trata-se de uma hipotética "declamação" para efeitos retóricos.

${ }^{145} \mathrm{Um}$ dos pontos principais da acusação referia-se à vida imoral desta personagem.

146 Ilíada, VI, 488, fala de Heitor ao despedir-se de sua esposa Andrómaca. 
Fiou-lhe o fio do destino, I mal a mãe o deu à luz $z^{147}$.

9. Se eu, porém, abandonar este argumento, por ele não ser muito convincente, e apresentasse um outro, [dizendo] que náo fui seduzido nem pelo dinheiro nem por nenhuma expectativa desse género que eu me submeti à actual sujeição, mas antes, que foi por admirar a inteligência, a coragem e a grandeza de alma da pessoa, que eu decidi participar dos seus actos, receio que à acusação agora feita contra mim venha juntar-se a de bajulaçáo e depois me ache, como sói dizer-se, a "tirar um prego com outro prego" 148 , e [neste caso], um menor com um maior ${ }^{149}$, pois a bajulação é considerada o mais servil - e portanto o pior — de todos os vícios.

10. Ora, já que não me agrada nem esta argumentação, nem a outra, que mais me resta, senão confessar que náo disponho de argumento válido? Mas talvez ainda tenha uma âncora disponível ${ }^{150}$ : lamentar a minha velhice, a doença e, além dessas, a pobreza, que obriga um homem a fazer e a suportar tudo, a fim de evitá-la. Neste caso, talvez não venha fora de propósito citar a Medeia de Eurípides, quando ela entra [em cena] e pronuncia, em minha defesa, os famosos iambos, agora um pouco parodiados ${ }^{151}$ :

Tenho plena consciência | do mal que vou praticar, mas a pobreza é mais forte |que todos os meus projectos ${ }^{152}$,

${ }^{147}$ Iliada, XX, 128.

${ }^{148}$ Provérbio muito sugestivo: ao fazermos sair um prego, batendo-lhe com outro prego, este vai ocupar o lugar do primeiro, com o que náo se resolve a dificuldade.

${ }^{149}$ Extensão do provérbio, da invenção do autor, e ainda mais sugestivo: O prego maior vai substituir o menor...

150 "de reserva”: O texto diz "seca”, i. é, fora de água, ainda sem uso, disponível...

${ }^{151}$ Eurípides, Medeia, 1078. Na tragédia, é Medeia quem pronuncia estes versos, mas note-se que Luciano faz uma alteração intencional: Onde se lia thümós $(\theta \cup \mu o ́ \varsigma)$ "paixão”, Luciano substitui por penía ( $\pi \varepsilon v i ́ \alpha)$ "pobreza”...

152 Medeia parece referir-se ao projecto inicial de poupar os filhos; aplicado a Luciano, trata-se dos belos projectos de preservar a sua liberdade. 
ou aquele passo de Teógnis, embora não o cite [textualmente] — quem náo o conhece? —- em que ele não considera nenhuma indignidade que os homens se lancem "no mar profundo, do alto de rochedos escarpados, para deste modo escaparem à pobreza"153?

11. Julgo que são estes os argumentos que uma pessoa, em tais circunstâncias, poderia aduzir em sua defesa, mas nenhum deles é muito especioso. Mas fica descansado, companheiro, que não vou utilizar nenhum deles. Sim, oxalá nenhuma [outra] fome se apodere de Argos, a ponto de [os seus habitantes] tratarem de semear o [ginásio ${ }^{154}$ de] Cilárabis ${ }^{155}$; nem eu ${ }^{156}$ estou assim táo carente de uma boa justificação, a ponto de, à falta de uma delas, procurar um refúgio desse género contra a acusação [que me é feita]. Ora repara bem nisto, em como é completamente diferente, por um lado, entrar para casa de um ricaço na situação de assalariado e suportar tudo aquilo que o meu livro descreve, e, por outro lado, executar uma tarefa pública em prol da comunidade e exercer o poder, e, por esse facto, receber do Imperador um salário. Analisando isoladamente, e depois comparando, ambas as situaçóes, reflecte bem, pois acharás - para utilizar linguagem musical — a diferença de duas oitavas. Estes dois modos de vida parecem-se um com o outro, como o chumbo com a prata, o cobre com o ouro, a anémona com a rosa, o macaco com o homem. Na verdade, em ambos os casos a pessoa recebe um salário e está às ordens de outrem, mas a situação é completamente diferente. De facto, num caso, há uma manifesta servidão, e aqueles que enveredam por tal modo de vida não diferem muito dos escravos comprados ou nascidos em casa [do senhor], ao passo que aqueles que têm entre mãos o interesse público e se tornam úteis às cidades e a províncias inteiras, não poderiam, naturalmente, ser acusados pelo simples facto de receberem salário, nem rebaixados em

153 Citação de memória de parte dos vv. 173-178, recuperando duas citaçóes de Contra os Assalariados dos Grandes, $\$ 5$.

${ }^{154}$ É conveniente notar que os ginásios, além dos edifícios, tinham um espaço ao ar livre, de terra e com vegetaçáo, onde se praticava a corrida.

155 Quando os Lacedemónios cercaram Argos, os seus habitantes, acossados pela fome, viram-se forçados a cultivar os terrenos anexos a este ginásio. Aqui, a citação está em sentido figurado: oxalá eu (Luciano) não tenha tanta falta de argumentos, que me veja na necessidade de usar os supramencionados.

156 "eu": O texto tem "nós", plural majestático. 
pé de igualdade e juntamente com o tipo de acusação comum. Desse modo, não tardaríamos a eliminar as funçôes desse género: nem os governadores de tantas províncias, nem os prefeitos das cidades, nem os comandantes de legióes ou de exércitos inteiros, nenhum deles procederia bem, visto que, na realidade, todos têm o seu salário. Portanto, náo devemos, julgo eu, com base num só caso, arrasar todos os outros e colocar ao mesmo nível todos quantos recebem salário.

12. Em resumo, eu não afirmei que todos os mercenários levavam uma vida mesquinha, mas lamentei somente os que serviam nas casas [particulares] a pretexto de serem professores. Todavia, ó companheiro, esta minha situação é completamente diferente, uma vez que, na minha vida privada, tenho um honroso estatuto, e na vida pública participo do máximo poder, do qual exerço uma parte. Ora, se reflectires bem, verás que eu tenho sob a minha responsabilidade uma parte nada insignificante da província do Egipto, pois instruo os processos, fixo-lhes a devida ordem de entrada, redijo as actas de tudo o que se faz e diz, controlo os discursos dos advogados, guardo os decretos do governador ${ }^{157}$ da maneira mais clara, mais precisa e com o maior zelo, e dou-lhes publicidade, a fim de serem preservados para sempre; além disso, o meu salário não é o de uma pessoa vulgar, mas vem [directamente] do Imperador ${ }^{158}$, e não é nada modesto, mas de muitos talentos ${ }^{159}$. A juntar a tudo isto, tenho expectativas nada modestas, se acontecer o que me parece natural: que me seja atribuída a [prefeitura da] província ou quaisquer outras funçóes imperiais ${ }^{160}$.

157 "governador": No tempo do Império, o Egipto era uma província imperial (e náo senatorial), que tinha como magistrado máximo o praefectus Aegypti.

${ }^{158}$ A designação grega do Imperador é, desde Augusto, basileús ( $\beta \alpha-$ $\sigma \imath \lambda \varepsilon v ́(\varsigma)$, cujo significado usual era "rei".

${ }^{159} \mathrm{O}$ talento não era uma moeda propriamente dita, mas uma «moeda de conto" (cf. contos de réis) $=60$ minas; uma mina $=100$ dracmas; uma $\mathrm{dracma}=6$ óbolos. Portanto, um talento $=6000$ dracmas. O termo $t a-$ lento podia referir-se, de maneira indeterminada, àquilo que designamos por «um balúrdio». É óbvio que Luciano não quer confessar o montante exacto (nem sequer aproximado) do seu salário.

160 "funçôes imperiais", ou seja, dependentes directamente do Imperador. Recorde-se que o Egipto era um província imperial, e não senatorial. 
13. Mas agora, usando de uma liberdade verbal acrescida e avançando para lá da acusação, pretendo levar mais longe a minha defesa, e entấo declaro-te que ninguém faz seja o que for sem ser pago, mesmo os que ocupam os mais altos cargos, onde nem sequer o Imperador fica sem receber pagamento, e náo me refiro aos impostos e aos tributos que ano após ano lhe chegam dos seus súbditos, pois o maior salário do Imperador são os louvores, a glorificação geral, as acçóes de graças pelos benefícios recebidos, estátuas, templos, santuários, que os seus súbditos lhe dedicam - tudo isto são formas de pagamento pelos cuidados e preocupaçóes que essas pessoas ${ }^{161}$ manifestam, olhando permanentemente pela coisa pública e tornando-a mais perfeita. Ora - comparando as coisas pequenas com as grandes - , se tu quiseres começar pelo cume do monte ${ }^{162} \mathrm{e}$ descer até cada um daqueles [elementos] de que ele se compóe, verás que nós diferimos dos do topo como do pequeno relativamente ao grande, mas, quanto ao resto, todos nós somos igualmente assalariados.

14. Ora, se eu tivesse instituído uma lei, segundo a qual ninguém devia exercer uma actividade [remunerada], é claro que eu seria culpado de violar essa lei; mas, se nada disso está dito no meu livro, mas sim que um homem de bem deve exercer uma actividade, que outra actividade mais decente poderia ele exercer, senão trabalhar em coisas úteis juntamente com os amigos, dando provas de fidelidade, de zelo e de amor às suas tarefas, de tal modo, que não seria, como diz o passo de Homero ${ }^{163}$,

\section{| fardo inútil sobre a terra.}

15. Mas, antes de mais, aqueles que me censuram devem lembrar-se de que não é um homem sábio - se é que existe algum que seja sábio - que eles se propóem censurar, mas sim um dos muitos homens vulgares, que, de facto, exerceu

161 "essas pessoas", ou seja, não só o Imperador, mas também os titulares de altos cargos, a que um pouco acima se faz referência.

162 "o cume do monte", ou, como diríamos, o vértice da pirâmide, ou seja, o Imperador.

163 Ilíada, XVIII, 104. 
a arte de falar e é razoavelmente elogiado por esse facto, mas que, no entanto, não está muito treinado naquela extrema virtude dos corifeus [da Filosofia]. E, por Zeus!, não devo ficar aborrecido por esse facto, pois nunca encontrei ninguém que cumprisse plenamente as promessas do sábio. De resto, muito me espantaria o facto de tu censurares, se é que censuras, o meu modo de vida actual, sabendo tu, como sabes, que, muito tempo atrás, eu auferia enormes remuneraçōes pelas liçōes públicas de Retórica, no tempo em que tu, durante uma visita ao Oceano ocidental, [aproveitaste e] foste até à Céltica ${ }^{164}$, onde me encontraste, e onde eu era tido como um dos mestres mais bem pagos.

Eis, companheiro, o que eu tenho para te dizer em minha defesa, apesar das minhas mil e uma ocupaçóes, mas por atribuir a maior importância ao voto branco e cheio ${ }^{165}$ vindo da tua mão. Quanto às outras pessoas, ainda que todas elas me condenassem por unanimidade, bastar-me-ia dizer a tal frase: "Hipoclides não liga a isso"166.

164 "Céltica", terras dos Celtas, ou seja, a Gália.

165 "voto branco e cheio", ou seja, voto de absolvição. De facto, cada jurado recebia duas rodelas de bronze, uma das quais estava furada no centro, significando condenaçáo, enquanto a outra estava inteira, significando absolvição.

166 "Hipoclides náo liga a isso" é uma frase tirada de um episódio contado por Heródoto, VI, 127-129, e que poderíamos traduzir por "Tanto se me dá, como se me deu", ou "Estou-me nas tintas". Em resumo: Este Hipoclides, ao fazer uma figura triste no final de um banquete, foi eliminado como pretendente de uma certa menina... com o que não se importou absolutamente nada. 
(Página deixada propositadamente em branco) 
MENIPO OU DESCIDA AOS INFERNOS 
(Página deixada propositadamente em branco) 


\section{INTRODUÇẤO}

A principal personagem desta narrativa, quer dizer, o narrador (que algumas vezes dialoga com um “amigo”), é Menipo de Gádaros ${ }^{167}$ (cidade da "Cele-Síria”), filósofo cínico do séc. III a.C. Na obra de Luciano, assume geralmente posições que são, afinal, as do próprio Luciano: crítica corrosiva das fraquezas, vaidades e maldades humanas. Neste caso, não o encontramos na condiçáo de morto (como, p. ex., nos Diálogos dos Mortos), mas na situação extraordinária de alguém que, por artes de um mago de Babilónia (um discípulo de Zoroastro), conseguira ir ao reino de Hades e regressar de lá.

De facto, este Menipo andava preocupado com o rumo definitivo que deveria dar à sua vida. Por isso, consulta os filósofos mais eminentes do seu tempo, mas verifica que eles não se entendem, nem mesmo a respeito dos mesmos conceitos. Por isso recorre a um mago babilónico, que o levará até ao adivinho Tirésias, um velho prudente e sábio, que certamente lhe fornecerá a chave do modo de se comportar na vida.

Esperaríamos, portanto, um encontro quase imediato com Tirésias, mas o seu interlocutor, o "Amigo" (que alguns editores identificam com um tal Filónides) está mais urgentemente interessado em saber coisas sobre o reino de Hades, nomeadamente sobre um certo decreto respeitante, e muito desfavorável, aos ricos e poderosos deste mundo. Ora, mesmo o famigerado decreto é relegado para mais tarde $(\$ 20)$. Eis a parte fulcral: (que as sua almas) penetrem nos corpos de burros, até que decorram, nesta situaçâo, vinte e cinco miriades de anos ${ }^{168}$, durante os quais passem [sucessivamente] de uns burros para outros, sempre transportando cargas e desancados pelos pobres, após o que lhes será permitido morrer". Só depois vem a visita a Tirésias $(\$ 21)$, que acaba por ser relativamente decepcionante na sua concisáo (ainda que, naturalmente, preciosa para Menipo), e que, em todo o caso, ocupa um espaço e um tempo narrativo nada consentâneo com o objectivo da visita. Diz Tirésias: " $A$ melhor forma de vida é a das pessoas comuns ${ }^{169}$, e tu serás mais

167 "Gádaros", melhor que "Gádara”.

168 "vinte e cinco miríades de anos": Uma miríade significa 10.000 (dez $\mathrm{mil}$ ), pelo que o valor proposto no decreto equivaleria a 250.000 (duzentos e cinquenta mil) anos. Em tempo "terrestre", é obra!

169 "pessoas comuns", com uma forte conotação de "ignorante". 
sensato, se deixares de te preocupar com os fenómenos celestes, de reflectir sobre os fins e os principios [das coisas], se escarrares ${ }^{170}$ nos silogismos desses sábios, considerando tais coisas uma patacoada, e se procurares, de entre todas as coisas, somente esta: a maneira de gozares o momento presente, seguindo o teu caminho rindo-te de tudo e não te preocupando com coisa nenhuma." Trata-se, portanto, do ideal de vida do Cinismo, que, afinal, já era, ou iria ser, seguido por Menipo.

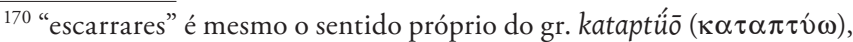
mas em grego já pode ter o sentido figurado de "desprezar" "estar-se marimbando", ou mesmo (fazendo apelo a uma função fisiológica) "estar-se [desculpe lá, raro leitor]... cagando para”. 


\section{Menipo ou Descida aos Infernos}

\section{MENIPO -}

Ó traves, eu vos saúdo, | e portais de minha casa! com que gáudio te contemplo, |à luz do sol regressado! ${ }^{171}$

$\mathrm{AMIGO}^{172}$ - Este tipo aqui não é Menipo, o cão? ${ }^{173}$. Não, náo é outro... a menos que eu esteja mal da vista. É mesmo Menipo em pessoa... Mas que quer dizer esta estranha indumentária capacete [forrado de feltro], lira e pele de leão? ${ }^{174}$ Ora bem, vou ao seu encontro... Ora viva, Menipo! Donde é que tu vens? Há já bastante tempo que não aparecias cá pela cidade.

MENIPO -

Venho do abismo dos mortos, | das portas da escuridão, onde Hades tem a morada, | longe de todos os deuses ${ }^{175}$.

AMIGO - Por Héracles! Será que não dei por Menipo ter morrido e agora voltou de novo à vida?

MENIPO -

Nada disso, pois em vida | o Hades me recebeu ${ }^{176}$.

AMIGO - E qual foi o motivo que te levou a fazer essa viagem inaudita e tão estranha?

${ }^{171}$ Eurípides, Héracles Furioso, 523-524. Na tragédia, a fala pertence a Héracles, acabado de sair do reino de Hades; em situação idêntica, Menipo profere os mesmos versos.

${ }^{172} \mathrm{O}$ interlocutor de Menipo não está explícito: alguns editores dão-lhe o nome de Filónides, enquanto outros o identificam vagamente como Amigo.

173 "cão" é o nome vulgarmente dado aos filósofos cínicos, aos künikoí

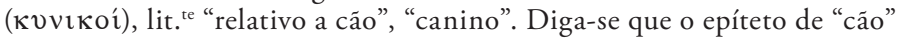
não lhes desagradava mesmo nada: até tinham muita honra...

174 "capacete de feltro, lira e pele de leão", referência a adereços típicos, respectivamente, de Ulisses, Orfeu e Héracles, três personagens que haviam penetrado do reino de Hades e que daí tinham saído. Ver-se-á adiante a utilidade destes disfarces...

175 Eurípides, Hécuba, 1-2. Na tragédia, fala a sombra de Polidoro, filho de Príamo, que havia sido morto por Aquiles.

${ }^{176}$ A forma métrica (trímetro jâmbico) aponta para a citação de uma tragédia perdida, talvez também de Eurípides. 
Incitou-me a juventude, | e audácia mais que bom senso $0^{177}$

AMIGO - Ó meu caro e bem-aventurado ${ }^{178}$ amigo, deixa-te lá de tragédias, desce dos iambos e fala mas é em simples prosa. Que farpela é essa? Que necessidade tinhas tu de te deslocares lá abaixo? Sim, que o caminho não é agradável nem acolhedor. MENIPO -

Meu caro, a necessidade | me levou ao reino de Hades, Para a alma consultar | de Tirésias, o tebano ${ }^{179}$.

AMIGO - Ó homem, deves estar doido, pois, caso contrário, não falarias em verso aos teus amigos.

MENIPO - Não fiques admirado, companheiro. Na verdade, estive recentemente com Eurípides e com Homero, e então, não sei lá como, encharquei-me dos seus versos, pelo que as suas frases métricas me vêm automaticamente à boca...

2. ... Mas diz-me: Como vão as coisas cá sobre a terra, e que fazem os habitantes desta cidade?

AMIGO - Nada de novo; tal como antigamente, rapinam, juram falso, praticam a usura, pesam os óbolos...

MENIPO - Infelizes, miseráveis, pois não sabem das decisôes que foram recentemente tomadas lá em baixo e das leis que foram promulgadas contra os ricos, das quais, por Cérbero! ${ }^{180}$, não há nenhuma forma de escapar.

AMIGO - Que é que estás a dizer? Foi promulgada lá em baixo uma nova lei a respeito das pessoas daqui?

177 Eurípides, fragmento da Andrómeda.

178 "Ó meu caro e bem-aventurado": O texto tem uma única palavra, makárie ( $\mu \alpha \kappa \alpha ́ \rho \imath \varepsilon)$, que se aplica aos mortos (bem-aventurados), mas se transforma rapidamente numa fórmula equivalente a "meu caro amigo". Neste passo, é impossível não entrever o primeiro sentido, pois Menipo, embora náo tivesse morrido, passou algum tempo no reino dos mortos...

${ }^{179}$ Homero, Odisseia, 164-165. Fala de Ulisses a sua mãe, que já se encontrava no reino de Hades. Note, no entanto, que no texto homérico se diz minha máe, que Menipo substitui, naturalmente, por meu caro.

${ }^{180}$ Cérbero é o feroz cáo do reino dos mortos, que morde em quem entra e não deixa sair ninguém... com notáveis excepçóes. 
MENIPO - Por Zeus!, uma grande quantidade... mas não me é lícito espalhá-las a toda a gente nem divulgar tais segredos, com receio de que alguém me intente um processo por impiedade no tribunal de Radamanto ${ }^{181}$.

AMIGO - De maneira nenhuma, ó Menipo. Por Zeus!, não te negues a falar a um amigo, pois estarás a falar a alguém que sabe guardar segredo e que, além do mais, é iniciado ${ }^{182}$.

MENIPO - Fazes-me um pedido ${ }^{183}$ bem difícil e não lá muito piedoso. No entanto, vou arriscar, atendendo à tua pessoa. Ora, foi decidido que esses ricaços, senhores de enormes fortunas, mas que guardam o dinheiro a sete chaves, como [aconteceu com] Dánae ${ }^{184}$... $^{185}$

AMIGO - Meu caro, não cites o decreto, antes de me narrares o que mais me agrada ouvir da tua boca, a saber, que ideia foi essa de fazer a viagem até lá abaixo, quem foi o teu guia de viagem, e depois, na devida ordem, que é que viste e ouviste nesse local. Sim, é de esperar que um homem de bom gosto, como tu és, não deixe passar despercebido nada que seja digno de ser visto e ouvido.

3. MENIPO - Tenho de prestar-te mais este serviço. Sim, que é que uma pessoa pode fazer, quando um amigo o obriga? Ora, em primeiro lugar, vou falar-te desta minha decisão, ou seja, do que me impeliu a descer até lá abaixo. Foi o caso que

${ }^{181}$ Radamanto é um dos três juízes do reino de Hades; os outros dois são Minos (seu irmão) e Éaco.

182 "iniciado", entenda-se: numa religião ou ritual de mistério, onde o segredo era imposto aos fiéis. Talvez aqui se faça referência especial aos mistérios de Elêusis, em honra de Deméter.

183 "pedido": gr. epitagma (દُ $\pi i ́ \tau \alpha \gamma \mu \alpha)$ significa "um pedido insistente, para obter algo mais ou menos ilegal", "uma espécie de "cunha”...

${ }^{184}$ Dánae, filha de Acrísio, rei de Argos. Segundo um oráculo, a rapariga daria à luz um filho, que mataria o avô materno. Para evitar que tal acontecesse, Dánae foi encerrada numa câmara interior, onde, afinal, Zeus penetrou sob a forma de uma chuva de gotas de oiro, as quais, infiltradas pelo tecto, caíram no seio da jovem, com o resultado fatal ao fim de nove meses. É claro que... ninguém foge ao seu destino...

185 Aqui, o amigo impede que Menipo comece sequer a citar a lei, o que não deixa de ser surpreendente. Trata-se de um processo de retardamento, justificado pelo facto de o amigo estar, afinal, mais interessado em saber como se passavam as coisas no reino de Hades. É claro que, quase no fim $(\$ 20)$, lá vem o relativamente curto decreto, que Luciano entendeu não dever citar no início... 
— era eu ainda rapaz — , ao ouvir Homero e Hesíodo narrarem guerras e sediçōes, não só entre semideuses ${ }^{186}$, mas também entre os próprios deuses, bem como os seus adultérios, violaçôes, raptos, processos judiciais, expulsões de pais e casamentos com irmãs, julgava que todos esses actos eram dignos, pelo que ficava não pouco impressionado com tudo isso. Quando, porém, cheguei à idade adulta, verifiquei que as leis diziam o contrário dos poetas, proibindo o adultério, as sediçóes e os raptos, pelo que me achei em grande embaraço, sem saber o que devia adoptar para minha orientação. Realmente, cuidava eu que os deuses nunca por nunca cometeriam adultério e sediçôes uns contra os outros, caso náo acreditassem que se tratava de boas acçóes, e, por outro lado, que os legisladores não ordenariam o contrário, se não o achassem mais vantajoso.

4. Estando eu nesta incerteza, resolvi procurar esses tais homens denominados filósofos, entregar-me nas suas mãos e solicitar-lhes que dispusessem de mim como entendessem e me indicassem um caminho de vida simples e seguro.

Com tal propósito, dirigi-me a esses homens, sem me aperceber de que, como sói dizer-se, "ao fugir do fumo, me lancei no fogo" 187 . De facto, ao observá-los, apercebi-me da sua ignorância e das suas incertezas, de tal modo, que depressa me convenceram de que essa tal vida dourada era a vida das pessoas comuns ${ }^{188}$.

Um deles aconselhava-me o máximo de prazer e a procurar por todos os meios somente este, pois era aí que residia a felicidade $^{189}$. Outro, pelo contrário, [aconselhava-me] a trabalhar afanosamente, a afadigar-me e a violentar o corpo, a andar sujo e imundo, desagradável para toda a gente e proferindo insultos, sempre a declamar aqueles conhecidos versos de Hesíodo ${ }^{190}$ a respeito da virtude, do suor e da subida até ao cume. Um exortava-me a abominar o dinheiro e a considerar a sua posse

186 "semideuses" ou "heróis" são seres nascidos de humano e divindade, como, p. ex., Aquiles, Ulisses, etc.

187 Provérbios portugueses correspondentes: "É pior a emenda que o soneto", ou "Saiu da lama, meteu-se no atasqueiro", ou ainda "Pensou que se benzia, partiu o nariz”...

${ }^{188}$ Mais explicitamente, opóem-se os filósofos (sábios) às pessoas comuns (ignorantes): são estes os que mais facilmente alcançam a felicidade.

${ }^{189}$ Doutrina dos epicuristas.

${ }^{190}$ Hesíodo, Os Trabalhos e os Dias, 287, ss.; Referência à doutrina dos estóicos e, em parte, também dos cínicos. 
como coisa indiferente, enquanto outro, pelo contrário, sustentava que a riqueza até era um bem ${ }^{191}$. E que dizer a respeito do mundo? Ao ouvi-los falar durante todo o dia de "ideias", "incorpóreos", “átomos" e "vazios"192 e um monte de vocábulos que tais, até ficava enjoado. Mas o mais absurdo de tudo era o facto de, ao dissertarem a respeito das coisas mais opostas, cada um deles aduzir argumentos triunfantes e persuasivos, de tal modo, que não era possível contradizer nem aquele que dizia que uma coisa era quente, nem o que dizia que era fria, quando se sabe seguramente que uma coisa náo pode ser simultaneamente quente e fria. Assim, acontecia-me o mesmo que àqueles que cabeceiam de sono: ora inclinava a cabeça para baixo, ora para cima ${ }^{193}$.

5. Mas havia [neles] uma coisa muito mais absurda. De facto, ao observá-los bem, fui descobrindo que a sua prática de vida era absolutamente contrária à sua doutrina. Por exemplo, os que pregavam o desprezo das riquezas, via-os afincadamente apegados a elas, altercando por causa de juros, ensinando por dinheiro e suportando tudo para o obterem, enfim, os que afirmam rejeitar a glória fazem e dizem tudo por esta causa, e quase todos eles, embora censurem o prazer, em privado só se entregam a ele.

6. Decepcionado na minha expectativa, ia ficando cada vez mais desgostoso, embora me consolasse um pouco com a ideia de que era juntamente com muitos homens sábios e muitíssimo elogiados pela sua inteligência, que eu era um insensato e procurava a verdade sem conseguir conhecê-la. Ora uma noite em que não conseguia adormecer por causa deste problema, resolvi deslocar-me a Babilónia, a fim de consultar um desses magos, discípulos e sucessores de Zoroastro, pois ouvia dizer que eles, por meio de certos encantamentos e ritos de iniciação, abriam as portas do Hades e introduziam aí, com

${ }^{191}$ Doutrina dos peripatéticos.

192 “ideias" e "incorpóreos” referem-se às doutrinas idealistas de Platão; “átomos" e "vazios" alude à doutrina materialista dos atomistas (Leucipo e Demócrito, e sobretudo Epicuro).


baixo", especialmente em sinal de assentimento; o contrário é ananeúō ( $\alpha \nu \alpha \nu \varepsilon v ́ \omega)$ "erguer a cabeça para trás ou para cima”, especialmente em sinal de discordância. Neste passo, fundem-se os dois sentidos. 
toda a segurança, quem eles quisessem, e conduziam-nos de novo cá acima. Pensei, pois, que o melhor seria conseguir que um deles me proporcionasse essa descida, a fim de ir ter com o beócio Tirésias e ficar a saber da sua boca, como adivinho e sábio que ele era, qual a melhor forma de vida que um homem sensato deve escolher.

Assim, saltei [da cama] e dirigi-me o mais depressa possível a Babilónia. Aí chegado, entro em contacto com um dos caldeus, homem sábio e prodigioso na sua arte, de cabelos grisalhos e de barba mui veneranda, cujo nome era Mitrobarzanes. Depois de muito pedir e suplicar, lá consegui dele, a muito custo e pela quantia que ele me exigiu, que fosse meu guia nessa caminhada.

7. Então o homem, pegando em mim, em primeiro lugar banhou-me durante vinte e nove dias, a começar na lua nova, mergulhando-me no Eufrates desde o nascer ao pôr do sol, ao mesmo tempo que recitava uma longa ladainha de que eu náo entendia nada, pois, como os maus arautos dos jogos, [o homem] falava muito rápida e atabalhoadamente. No entanto, parecia invocar certas divindades. Depois das fórmulas encantatórias, cuspia-me três vezes no rosto, e só depois é que eu regressava [a casa], sem olhar para ninguém que encontrasse [no caminho]. A nossa comida eram frutos secos, e a bebida era leite, hidromel e água do [rio] Coaspes; quanto a cama, era ao ar livre, sobre a erva.

Quando entendeu que já me tinha ministrado o tratamento preparatório suficiente, levou-me, aí por volta da meia-noite, até ao rio Tigre, onde me lavou, me esfregou e me untou todo com cebola albarrá e muitos outros ingredientes, ao mesmo tempo que murmurava a tal fórmula encantatória. A seguir, depois de fazer muitos feitiços andando à minha volta, a fim de náo ser molestado pelos fantasmas ${ }^{194}$, leva-me para casa, tal e qual como estava, e andando às arrecuas. Então, preparámos tudo para o embarque.

8. O meu guia envergou um veste de mago, muito parecida com a dos Medos, e a mim ataviou-me com estas ${ }^{195}$ coisas: o capacete [forrado de feltro], a pele de leão e a lira,

${ }^{194}$ Recorde-se que Menipo ia visitar o reino das sombras...

195 "estas": Recorde-se que Menipo acabava de regressar do reino de Hades, ainda ataviado com "estas coisas", que a seguir especifica. 
e recomendou-me que, se alguém me perguntasse como me chamava, não dissesse que era Menipo, mas sim Héracles, ou Ulisses, ou Orfeu.

AMIGO - Mas para quê tal coisa, ó Menipo? Não percebo a razão nem do disfarce nem dos nomes.

MENIPO - E no entanto, é coisa evidente e mesmo nada misteriosa. De facto, uma vez que, antes de nós, aquelas personagens desceram ao Hades ainda em vida, o meu guia pensou que, se eu me disfarçasse dessas figuras, facilmente, graças à minha aparência, enganaria os guardas de Éaco e passaria sem impedimento, como pessoa conhecida, para mais ali enviado em traje de tragédia.

9. Já a luz do dia ia despontando, quando nós descemos até à margem do rio e estávamos prestes a partir. O guia tinha preparado a barca, as vítimas, o hidromel e todos os demais objectos necessários ao ritual. Tendo, pois, embarcado todos os apetrechos, também nós

ansiosos embarcámos, | vertendo abundantes lágrimas ${ }^{196}$.

Durante um certo tempo, fomos levados pelo rio; depois, penetrámos num pântano e num lago onde o Eufrates se perde. Tendo-o atravessado, chegámos a uma região erma, densamente arborizada e onde o sol não penetrava, onde desembarcámos e, sob a direcção de Mitrobarzanes, abrimos uma fossa, imolámos as ovelhas e vertemos o seu sangue na fossa, em libação. Então o mago, com uma tocha ardente na mão, e com uma voz já não calma, mas altissonante o mais que ele podia, lançava gritos [estridentes], ao mesmo tempo que invocava todos os espíritos, as Punições, as Fúrias ${ }^{197}$,

e Hécate sombria, | e Perséfone temivel ${ }^{198}$,

${ }^{196}$ Homero, Odisseia, XI, 5.

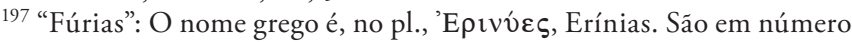
de três: Tisífone, Megera e Alecto. Nascidas da Terra ensopada com o sangue do mutilado Úrano, sáo divindades vingadoras dos grandes crimes de ordem familiar. No entanto, em certas condiçóes, podem transformar-se em divindades benfazejas: passam a ser as Euménides.

${ }^{198}$ Verso de obra perdida, ou simples inspiração de parte de Homero, Odisseia, XI, 47. 
misturando-lhes uns quantos nomes bárbaros, ininteligíveis e de muitas sílabas.

10. De repente, tudo começou a tremer e, por acção do encantamento, rasgou-se o chão, ouviu-se ao longe o ladrado de Cérbero, o ambiente pôs-se medonho e tenebroso,

\section{tremeu lá nas profundezas $\mid$ Aidoneu, senhor dos mortos ${ }^{199}$,}

e viu-se a maior parte [do Inferno] — o lago, o Piriflegetonte ${ }^{200}$ e o palácio de Plutão ${ }^{201}$. Então nós, tendo descido através do abismo, encontrámos Radamanto, que por pouco náo morrera de medo. Quanto a Cérbero, ainda nos ladrou um pouco e ficou nervoso, mas logo que eu dedilhei a lira, ficou imediatamente enfeitiçado com a melodia. Quando chegámos ao lago, por pouco que não embarcávamos, pois a barca já estava cheia, pejada de pessoas que gemiam, todos a bordo estavam feridos, este numa perna, aquele na cabeça, outro em qualquer outra parte [do corpo], vindos, segundo me pareceu, de alguma guerra. Mal, porém, o bom do Caronte viu a minha pele de leão, tomando-me por Héracles, mandou-nos ${ }^{202}$ embarcar e não só nos transportou com todo o gosto, mas também, ao desembarcarmos, nos indicou a vereda.

11. Como caminhávamos nas trevas, Mitrobarzanes ia à frente, enquanto eu seguia atrás, muito chegado a ele... até que chegámos a uma extensa pradaria toda coberta de asfódelo ${ }^{203}$, onde as sombras dos mortos adejavam à nossa volta, soltando sons agudos. Avançando devagarinho, chegámos ao tribunal de Minos, que estava sentado num trono elevado, ladeado pelas Puniçôes ${ }^{204}$, pelas Fúrias e pelos [espíritos] Vingadores. Do lado

${ }^{199}$ Homero, Iliada, XX, 61. Aidoneu é outro nome de Hades.

${ }^{200}$ Piriflegetonte, o rio de fogo.

${ }^{201}$ Plutão, outro nome de Hades.

202 "mandou-nos ... nos transportou": O texto não é explícito, pois também podíamos entender “... -me ... me...”, mas logo a seguir lê-se “a nós desembarcados...” (trad.: "ao desembarcarmos”).

203 O asfódelo é uma "planta liliácea, de raiz tuberosa e belas flores ornamentais" ("Lello"). Julgo tratar-se de uma espécie de lírio ("Olhai os lírios do campo...").

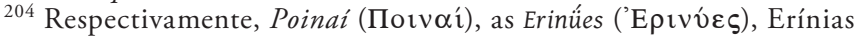

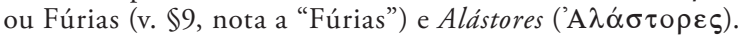


oposto [ao nosso], iam sendo trazidas muitas pessoas, em fila e presas por uma longa corrente. Dizia-se que eram os adúlteros, os proxenetas, os publicanos ${ }^{205}$, os aduladores, os sicofantas e toda uma multidão de pessoas que causam distúrbio na vida. Separados destes, vinham os ricos e os agiotas, muito pálidos ${ }^{206}$, barrigudos e gotosos, cada um deles com uma corrente ao pescoço e carregando uma esfera ${ }^{207}$ de dois talentos [de peso]. Então nós, tendo-nos aproximado, observámos o que se passava e escutávamos as suas justificaçóes. Quem os acusava eram uns oradores de nova espécie e muito estranhos.

AMIGO - Por Zeus!, que oradores eram esses? Não hesites em mo dizer.

MENIPO - Conheces por acaso essas sombras dos nossos corpos, quando estes estão expostos ao sol?

AMIGO - Claro que sim.

MENIPO - Pois bem, essas mesmas, quando nós morremos, denunciam-nos, depõem contra nós e expõem todos os actos que nós cometemos durante a vida... e é que são mesmo consideradas dignas de crédito, uma vez que estão sempre juntinhas aos nossos corpos e nunca se afastam deles.

12. Então Minos, depois de os examinar escrupulosamente, enviava cada um deles para a região dos ímpios, a fim de cumprirem a pena de acordo com os crimes cometidos; mas tratava com especial rigor aqueles que se envaideciam com as suas riquezas e quase se achavam dignos de serem adorados, e detestava a sua efémera fanfarronice e a sua soberba, e ainda mais pelo facto de não se lembrarem de que, sendo mortais, possuíam bens também mortais. Estes, despojados de todos esses magníficos bens, quero eu dizer, riquezas, nobreza e

${ }^{205}$ Os publicanos eram cobradores (arrematadores) de impostos, que pagavam ao Estado uma certa quantia, para terem o direito de cobrar, para si próprios, os impostos devidos pelos cidadáos. Imagina-se o "zelo" com que o faziam, bem como o ódio que suscitavam.

206 "pálidos": Alusão ao facto de não verem a luz do dia, por estarem sempre encerrados a contar o dinheiro e a fazer o cálculo dos juros.

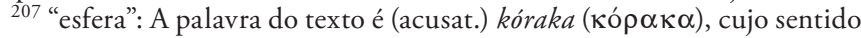
próprio é "corvo", mas aqui (e parece que só aqui) trata-se obviamente de um objecto de punição, talvez uma esfera, que, neste caso, pesaria "2 talentos”, i. é, mais de $70 \mathrm{~kg}$, que os condenados carregavam nas mãos ou (outra possibilidade) arrastavam ao andar... É muito difícil imaginar por que motivo essa esfera (se disso se tratava) se denominava "corvo". 
poderio, ali estavam, de pé, nus e de cabeça baixa, rememorando, como se fosse um sonho, a sua felicidade cá na terra. Pela minha parte, fartava-me de gozar com esse espectáculo, e, se por acaso reconhecia algum deles, aproximava-me e, muito docemente ${ }^{208}$, recordava-lhe como ele era durante a vida, como era todo emproado, nesse tempo em que muitos homens, logo de manhãzinha, se postavam à sua porta, aguardando a sua saída, empurrados e mantidos à distância pelos criados. Finalmente o senhor, aparecendo-lhes vestido de púrpura, coberto de ouro e todo garrido, julgava que tornava felizes e venturosos aqueles que o saudavam, deixando-os beijar-lhe o peito ou oferecendo-lhes a mão direita. E eles, ao ouvirem-me [recordar-lhes essas coisas], ficavam muito tristes.

13. Todavia, Minos pronunciou uma sentença favorável. Foi o caso que, tendo Dionísio da Sicília sido acusado por Díon de muitos e horríveis crimes de impiedade, testemunhados pela sua sombra, e estando prestes a ser lançado à Quimera, apresentou-se Aristipo de Cirene - tido em grande consideração e tem enorme influência no reino subterrâneo - , que o livrou da condenação, alegando o facto de Dionísio ter sido generoso a dar dinheiro a muitos intelectuais.

14. Tendo deixado o tribunal, chegámos à zona dos suplícios. Aí, meu caro amigo, podiam ouvir-se e ver-se muitas cenas dignas de dó: ouvia-se o estalar dos chicotes, juntamente com os gritos dos que eram assados no fogo, [viam-se] as máquinas de torturar, as golilhas ${ }^{209}$, as rodas, a Quimera despedaçava, Cérbero devorava. Todos eram punidos sem distinção: reis e escravos, sátrapas e mendigos, ricos e pobres, todos arrependidos dos seus crimes. Ao vê-los, reconhecemos alguns deles, os que tinham morrido recentemente; eles, porém, procuravam esconder-se ou voltavam-nos as costas, e se por acaso olhavam para nós, faziam-no mais numa atitude servil e aduladora, e no entanto, eram em vida pessoas duras e altivas. Em todo o caso, aos pobres só era infligida metade do castigo: davam-lhes uma

208 "muito docemente"... e muito cinicamente...

${ }^{209}$ A golilha, em lat. denominada numella, era um aparelho de tortura muito incómodo para o condenado, que, com o tronco em ângulo recto com o corpo, tinha o pescoço metido numa grade. V. imagem no dic. de Bailly, s. v. numella. 
folga, e depois voltavam a castigá-los. Além disso, vi também as famosas figuras da mitologia: Ixíon, Sísifo, o frígio Tântalo, o qual estava num sofrimento horrível, e ainda Tício, filho da Terra... Este, por Héracles!, ocupava, deitado, o espaço de um campo.

15. Depois de passarmos por estes, penetrámos na planície do Aqueronte ${ }^{210}$, e aí encontrámos os heróis ${ }^{211}$ e as heroínas, bem como toda a outra multidáo dos mortos, divididos por naçóes e tribos, alguns já muito antigos e bafientos, e, como diz Homero, inconsistentes, e outros novos ${ }^{212}$ e mais sólidos, sobretudo os egípcios, devido à longa duração do tratamento com salmoira. Aliás, não era muito fácil distingui-los um por um, pois eram todos absolutamente iguais uns aos outros, assim descarnados até aos ossos. Mesmo assim, embora com dificuldade e só depois de os fixarmos longamente, ainda os reconhecíamos. Jaziam amontoados na sombra, indistintos e já sem conservarem nada da beleza que tinham cá na terra. Quer dizer, com tantos esqueletos jazentes no mesmo local, todos eles a fixarem-nos com o mesmo olhar terrível e vazio e mostrando-nos aqueles dentes descarnados, eu tinha muita dificuldade em distinguir Tersites do formoso Nireu, ou o mendigo Iro do rei dos Feaces, ou o cozinheiro Pírrias de Agamémnon, uma vez que náo lhes restava nada das antigas características, mas, pelo contrário, os seus ossos eram iguais, anónimos, sem qualquer inscrição e impossíveis de identificar por qualquer outro meio.

16. Então, ao ver tudo aquilo, ocorreu-me comparar a vida dos humanos a uma longa procissáo, em que a Sorte atribuía e ordenava cada papel, dando diferentes e variadas vestes aos

${ }^{210}$ O Aqueronte, o Piriflegetonte e o Cocito eram os rios infernais.

211 "heróis" ou "semideuses" são seres nascidos de humano e divindade, como, p. ex., Aquiles, Ulisses, etc. O texto chama-lhes "semideuses", mas, ao contrário do que sucede no $\$ 3$, preferi traduzir por "heróis”, pelo facto de a seguir se mencionarem as "heroínas".

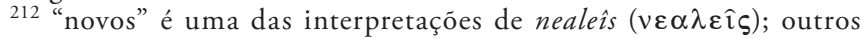
entendem "recém-salgados" (2o elemento háls "sal”), i. é, mumificados, ou ("Loeb") "bem preservados". A 1a interpretação, "novos", joga com "antigos", ao passo que a $2^{\text {a }}$ antecipa a referência ao processo egípcio de embalsamamento e conservação à base de salmoira. 
participantes. De facto, tomando um à sorte ${ }^{213}$, veste-o de rei, póe-lhe uma tiara, dá-lhe uma guarda pessoal e coloca-lhe uma coroa na cabeça, ao passo que a outro dá uma veste de escravo; faz deste uma pessoa bela, e de outro um tipo feio e ridículo. $\mathrm{Na}$ verdade, convém que o espectáculo seja variado. Muitas vezes, porém, em plena procissão, muda as vestes de alguns, não permitindo que eles marchem até ao fim como lhes tinha sido fixado, mas, pelo contrário, faz Creso mudar de vestimenta, obrigando-o a envergar as vestes de um escravo ou de um prisioneiro; e a Meândrio, que até então caminhava entre os criados, veste-o com as vestes do tirano Polícrates. Todavia, passado o período da procissáo, nesse mesmo instante, cada um devolve os adereços e despe a veste, ficando com o corpo que antes tinha, de modo que não se distingue do vizinho. Alguns, por ignorância, quando a Sorte se apresenta a reclamar-lhes os ornamentos, ficam desolados e irritados, como se tivessem sido despojados de bens próprios e não como se tivessem de restituir o que lhes tinha sido emprestado a título provisório.

Julgo que já tens observado muitas vezes o facto de alguns actores trágicos, por necessidade das peças, fazerem ora de Creonte, ora de Príamo, ora de Agamémnon; e o mesmo homem, a quem calhou, um pouco antes, desempenhar, aliás muito honrosamente, o papel de Cécrope ou de Erecteu, um pouco depois, por ordem do poeta, entra em cena como criado. Depois, terminada a peça, cada um dos actores despe a vestimenta bordada a ouro, tira a máscara, desce dos coturnos e volta a ser pobre e humilde, e já não Agamémnon filho de Atreu, ou Creonte filho de Meneceu, mas sim Polo filho de Cáricles, [natural] de Súnio, ou Sátiro filho de Tegíton, de Maratona ${ }^{214}$.

Assim é a vida humana, tal como então se me afigurou, ao observar [aquele espectáculo].

17. AMIGO - Mas diz-me cá, ó Menipo: Aqueles que, cá na terra, têm esses luxuosos e altos túmulos, ou colunas, estátuas e inscriçóes, não são, lá no Hades, mais honrados que os mortos comuns?

213 "à sorte": Preferi esta tradução, em vez de "ao acaso", pelo facto de o texto grego dar o mesmo nome à deusa Sorte e à ideia sorte: túkhē ( $\tau u ́ \chi \eta)$.

${ }^{214}$ Polo e Sátiro eram dois famosos actores do período clássico ateniense. 
MENIPO — Estás doido, meu caro. Se tivesses visto Mausolo em pessoa - refiro-me ao rei da Cária, famoso pelo seu túmulo $^{215}$ —, de certeza que náo paravas de rir, [vendo-o] assim abandonado a um canto, despercebido no meio do restante povo dos mortos e - foi o que me pareceu - tendo como único gozo tirado do seu monumento o facto de estar pesadamente esmagado pelo enorme peso deste. Ora, companheiro, quando Éaco mede a cada um o seu lugar - atribuindo a cada pessoa, no máximo, não mais que um pé quadrado ${ }^{216}$ - é forçoso que a pessoa se contente em deitar-se acomodada à medida. Mas creio que te terias rido ainda mais, se tivesses visto aqueles que cá na terra eram reis e sátrapas, e que lá em baixo andam a mendigar ou, forçados pela indigência, a vender peixe salgado, ou como professores de primeiras letras, insultados por toda a gente e apanhando bofetôes como se fossem os mais ignóbeis dos escravos. Náo fui capaz de me conter, ao ver o próprio Filipe da Macedónia, que me surgiu a um canto a remendar botas rotas em troca de salário. Também podiam ver-se muitos outros a mendigarem nas encruzilhadas, como, por exemplo, os Xerxes, os Darios e os Polícrates ${ }^{217}$.

18. AMIGO - É espantoso e pouco menos que inacreditável o que me contas a respeito dos reis. E entâo Sócrates... que é que ele fazia, bem como Diógenes e todos esses sábios?

MENIPO - No que respeita a Sócrates, continuava, lá em baixo, a passear e a refutar toda a gente. Está junto de Palamedes, de Ulisses, de Nestor e de todos os tagarelas defuntos, e as pernas estavam balofas e inchadas por efeito da droga ingerida ${ }^{218}$. Quanto ao camarada Diógenes, reside ao lado do

${ }^{215}$ É um tanto estranho que Luciano tenha sentido a necessidade de especificar de que Mausolo se tratava; na verdade, parece que havia pelo menos mais uma personagem com esse nome... mas o ilustre defunto em cuja honra sua esposa mandou erigir o Mausoléu deveria ser inconfundível...

${ }^{216} \mathrm{Um}$ pé equivale mais ou menos a $30 \mathrm{~cm}$, mas aqui trata-se obviamente de uma medida, não de comprimento, mas de superfície, pelo que traduzi por "um pé quadrado", uma área muito reduzida, mesmo atendendo ao facto de as almas serem "inconsistentes".

217 “os Xerxes, os Darios e os Polícrates”, ou seja $o$ Xerxes, $o$ Dario e $o$ Polícrates... e outros como eles. Trata-se de um plural depreciativo.

${ }^{218}$ Referência à cicuta, que fazia inchar os membros inferiores, antes de subir pelo corpo, até que, ao chegar á altura do coração, causava a morte de quem a ingeria. 
assírio Sardanapalo, do frígio Midas e de mais alguns ricaços. Ao ouvi-los a gemer, enumerando a sua antiga fortuna, escarnece e goza com eles, e muitas vezes, deita-se de barriga para o ar e canta com uma voz áspera e dura, que se sobrepóe aos eus gemidos, a ponto de esses tipos ficarem muito incomodados e pensarem em mudar de sítio, por não suportarem Diógenes.

19. AMIGO - Bem, já basta... Então qual foi esse tal decreto contra os ricos, de que me falaste ao princípio?

MENIPO - Lembraste bem. Na verdade, não sei lá como, tendo-me proposto falar desse assunto, depois perdi-me com a conversa. Foi o caso que, durante a minha estada lá entre eles, os prítanes ${ }^{219}$ convocaram uma assembleia, a fim de se tratar de assuntos de interesse comum. Então eu, vendo acorrer tanta gente, misturei-me com os mortos, e assim tornei-me um dos membros da Assembleia. Foram tratados diversos assuntos, e, em último lugar, o que respeitava aos ricos. Tendo eles sido acusados de muitos crimes graves, como violência, presunção, arrogância, injustiça, por fim um dos demagogos levantou-se e leu uma proposta de decreto mais ou menos nos termos seguintes:

\section{PROPOSTA DE DECRETO}

Considerando que os ricos, durante a sua vida, cometem muitos actos criminosos, rapinando, violentando e humilhando os pobres de todas as maneiras,

O Senado e o Povo decretaram que, quando eles morrerem, os seus corpos sejam punidos como os dos demais criminosos, mas que as suas almas sejam enviadas lá para cima, para a vida [na terra] e penetrem nos corpos de burros, até que decorram, nesta situação, vinte e cinco miríades de anos ${ }^{220}$, durante os quais passem [sucessivamente] de uns burros para outros, sempre transportando cargas e desancados pelos pobres, após o que lhes será permitido morrer.

${ }^{219}$ Os prítanes eram os magistrados supremos que, entre outras funções, convocavam e dirigiam as assembleias. Aqui faz-se referência, naturalmente, aos três juízes do reino de Hades: Minos, Éaco e Radamanto...

220 "vinte e cinco miríades de anos": Uma miríade significa 10.000 (dez mil), pelo que o valor proposto no decreto equivaleria a 250.000 (duzentos e cinquenta mil) anos. Em tempo "terrestre", é obra! 
Apresentou esta proposta Crânion'221, [filho] de Esquelétion, do demo de Necísio, da tribo de Alibântide.

Lida esta proposta de decreto, os magistrados puseram-na à votação, tendo sido aprovada por unanimidade, de braço no ar, ao passo que Brimo bramiu ${ }^{222}$ e Cérbero ladrou, pois é deste modo que as propostas são aprovadas e ganham força de lei.

21. Foi isto o que se passou na Assembleia. Depois eu, como era o objectivo da minha visita, fui procurar Tirésias, a quem contei tudo e a quem supliquei que me dissesse qual era, na sua opinião, a melhor forma de vida. Então ele - era um velhinho cego, muito pálido e com uma voz muito fina -, sorriu e disse: "Meu filho, eu sei bem o motivo do teu embaraço, causado pelos sábios, que, lá entre eles, não têm a mesma opinião sobre as mesmas coisas. No entanto, não me é permitido dizer-te, pois Radamanto proibe [que se revele]." "De modo nenhum, ó paizinho — disse eu -, mas fala, não permitas que eu ande pela vida mais cego que tu." Então ele, puxando-me à parte e afastando-se bastante dos outros, aproximou-se do meu ouvido e disse em voz muito baixa: "A melhor forma de vida é a das pessoas comuns ${ }^{223}$, e tu serás mais sensato, se deixares de te preocupar com os fenómenos celestes, de reflectir sobre os fins e os princípios [das coisas], se escarrares ${ }^{224}$ nos silogismos desses sábios, considerando tais coisas uma patacoada, e se procurares, de entre todas as coisas, somente esta: a maneira de gozares o momento

${ }^{221}$ A identificação do proponente é feita nos precisos termos legais: Fulano, filho de Beltrano, do demo $X$, da tribo $Y$. Os nomes, porém, são da invenção de Luciano, todos ligados à ideia de morte, respectivamente: "crânio" (ou "caveira"), "esqueleto", "morto" (ou "cadáver") e, de modo mais subtil, "sem seiva" (ou "sem sangue", ou "morto"), mas também com ligação ao rio da morte, o Estige; Para os antigos, alíbas, gen. alíbantos ('A $\lambda \hat{i} \beta \alpha \varsigma$, , 'A $\lambda \hat{i} \beta \alpha \nu \tau o \varsigma)$ significava “impróprio para libaçôes". É possível que os leitores contemporâneos de Luciano tenham achado mais graça a estas invençōes onomásticas.

222 "Brimo bramiu": Em primeiro lugar, Brimó (B epíteto de Hécate, aqui designada pelo epíteto, para jogar com brimésato

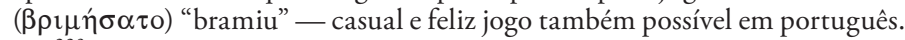

223 "pessoas comuns", com uma forte conotação de "ignorante".

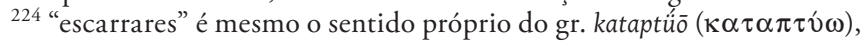
mas em grego já pode ter o sentido figurado de "desprezar" "estar-se marimbando", ou mesmo (fazendo apelo a uma função fisiológica) "estar-se [desculpe lá, raro leitor]... cagando para". 
presente, seguindo o teu caminho rindo-te de tudo e não te preocupando com coisa nenhuma."

Assim falando, se foi $\mid$ pelos prados asfodélios ${ }^{225}$.

22. Então eu - pois já se fazia tarde - digo: "Vamos, Mitrobarzanes, porque é que tardamos em regressar à vida?", ao que ele respondeu. "Tem calma, Menipo, pois vou indicar-te um atalho rápido e cómodo." $\mathrm{E}$ de facto, tendo-me conduzido a um sítio mais sombrio que os outros, apontou-me com a mão, lá ao longe, uma luz quase indistinta e muito fraquinha, escoada como que por um buraco de fechadura, e disse-me: "Aquilo ali é o santuário de Trofónio 226 , por onde descem os da Beócia. Portanto, sobe até lá, e encontrar-te-ás imediatamente em solo da Grécia."

Entáo eu, todo contente com aquelas palavras, saudei o mago, após o que, rastejando com muita dificuldade por essa abertura acima, eis que, sem saber como, encontrei-me em Lebadia.

${ }^{225}$ Verso feito de várias partes de Homero.

${ }^{226}$ Este santuário era, mais propriamente, uma gruta, meio natural, meio artificial, na encosta de uma montanha perto de Lebadia, na Beócia. O consulente do oráculo tinha de levar um bolo em cada máo, descer por caminhos de trevas, num ambiente aterrador e, a certa altura, muitíssimo estreito. Imagina-se o efeito psicológico... A gruta de Trofónio era uma das entradas para a reino dos mortos. 
A TRAVESSIA PARA O HADES OU O TIRANO 
(Página deixada propositadamente em branco) 


\section{INTRODUÇẤO}

O barqueiro do Inferno, Caronte, está impaciente com a demora de Hermes, que há muito deveria ter chegado com uma provisáo de mortos.

A demora é justificada pelo facto de o deus psicopompo, ou seja, "condutor de almas"227, ter apanhado pela frente um poderoso tirano, fortemente agarrado à vida e aos seus luxos, que lança mão de todas as artimanhas para se evadir.

Enfim, Hermes traz um "carregamento" bastante razoável, por exemplo: 300 crianças, 398 velhos, 84 feridos, 16 vítimas de assalto, 7 suicidas, mortos no mar, vítimas de doença...

Entre os mortos encontra-se Cinisco (lit. "e "cáozinho"), “filósofo de profissão" (\$23), quer dizer, filósofo cínico, completamente colaborante com as "autoridades" (Hermes, Caronte, a Parca Cloto...) e, daí a pouco, objecto do normal julgamento pelo juiz Radamanto, mas também acusador do tirano Megapentes. Cinisco apresenta-se completamente limpo de estigmas, apenas com algumas leves cicatrizes, pelo que não sofre qualquer punição; o mesmo acontece com o sapateiro Micilo, para quem a morte foi um alívio, uma libertação.

A acusação feita ao tirano Megapentes $(\$ \$ 26$, ss.) é um rol de crimes e infâmias, comprovadas pelos inúmeros estigmas que cobrem todo o seu corpo, crimes esses que o próprio acaba por confessar, com excepção dos crimes de natureza sexual. Cinisco, porém, convoca como testemunhas de acusação duas "personagens" muito curiosas, as quais, pela sua posição no palácio do tirano, conheciam melhor que ninguém as patifarias de Megapentes, pelo que confirmam as acusaçóes feitas por Cinisco: a Cama e a Candeia...

A punição que Radamanto se propóe aplicar ao tirano consiste em lançá-lo no Piriflegetonte, o "rio de fogo", mas Cinisco sugere um castigo maquiavelicamente cruel: Que o homem, ao contrário da "lei" do Hades, que manda que todos bebam água do rio Lete, o rio do "esquecimento", que apaga toda a memória da vida na terra, seja condenado precisamente à pena de não beber água do Letes, pois desse modo estará sempre lembrado da bela vida que levava na terra, da qual está definitivamente privado: "Levem-no para junto de

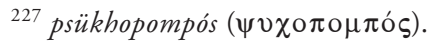


Tântalo, ponham-no a ferros, e que esteja sempre lembrado dos actos que praticou durante toda a vida” (\$29, fim). 


\section{A Travessia para o Hades ou O Tirano}

Personagens: Caronte, Cloto, Hermes, Cinisco, Megapentes, Micilo, diversos mortos, Tisífone, Radamanto, Cama, Candeia

1. CARONTE - Ora bem, Cloto ${ }^{228}$, já desde há muito que temos a barca aparelhada e completamente pronta a largar. De facto, a água foi escoada ${ }^{229}$, o mastro está erguido ${ }^{230}$, a vela içada, e cada um dos remos está enfiado na [respectiva] correia. Portanto, nada nos impede, julgo eu, de levantar ferro e zarpar. Mas Hermes está atrasado, já cá devia estar há muito tempo. Como vês, o barco está vazio de passageiros, quando já poderia ter feito hoje três viagens. Já é quase sol posto $^{231}$, e ainda não ganhámos um óbolo ${ }^{232}$ sequer. Depois Plutão - tenho a certeza - vai pensar que eu é que negligenciei o serviço, quando a culpa é de outro... O nosso condutor de mortos ${ }^{233}$, um tipo excelentíssimo como os que o são, deve ter bebido, lá em cima, água do Lete ${ }^{234}$, pelo que se esqueceu de regressar até nós, ou então ficou a praticar luta com os efebos, ou a tocar cítara, ou está a pronunciar algum discurso em que patenteia a sua grande lábia, ou - quem

${ }^{228}$ Cloto, gr. Klōthó (K $\left.\lambda \omega \theta \omega ́\right)$, nome feminino, é uma das três Parcas ou Meras (gr. Moî $\rho \alpha$ ): Átropo, fem. (que fiava a vida humana), Cloto (que enrolava o fio) e Láquesis (que cortava o fio da vida humana). A referência à segunda Parca significa que a terceira ainda náo tinha cortado o fio da vida de nenhum humano. De facto, a barca ainda estava vazia.

${ }^{229}$ Era difícil evitar que os barcos metessem água, a qual, por vezes até mesmo durante a viagem, tinha de ser escoada... até nova operação...

${ }^{230}$ Alguns barcos, mais pequenos ou mais modestos, não tinham o mastro permanentemente erguido. Por exemplo, em caso de tempestade, o mastro podia ser retirado do encaixe e colocado horizontalmente. Quando era necessário (ou preferível) navegar à vela, era posto na sua posição vertical. Note que o texto tem histós (i $\sigma \tau$ đós), "mastro", e não (como, à primeira vista, nos pareceria mais lógico) histion (i $\sigma \tau i ́ o v)$, "vela". Aliás, a referência a "vela" vem logo a seguir...

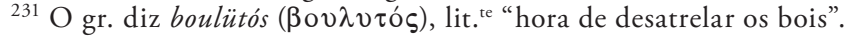

${ }^{232}$ Cada passageiro devia pagar a passagem, que custava um óbolo.

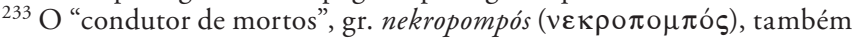
denominado psükhopompós ( $\psi v \chi 0 \pi \mathrm{o} \mu \pi \mathrm{c} \varsigma$ ), "condutor de almas" é Hermes.

${ }^{234} \mathrm{O}$ rio Lete, ou rio do esquecimento, apagava a memória dos tempos vividos sobre a terra; neste caso, uma vez que Hermes estava na terra, esquecia-se, sim, mas do reino de Hades. 
sabe lá!... - de passagem, vai furtando alguma coisinha, o espertalhão. Sim, que esta é uma das suas habilidades ${ }^{235}$. Mas o fulano toma certas liberdades connosco, embora seja dos nossos só pela metade ${ }^{236}$.

2. CLOTO - Sabes lá, Caronte, se não lhe caiu em cima alguma tarefa, se Zeus não precisou de o utilizar para alguma função extraordinária lá em cima...? Zeus também é seu amo.

CARONTE - Está muito bem, Cloto, mas não a ponto de mandar, para além da medida, no que é pertença comum, porquanto, pela nossa parte, nós também nunca o retivemos, sempre que ele precisava de sair. Mas eu sei qual a causa disso: é que cá entre nós só existe asfódelo ${ }^{237}$, libações, bolos dos mortos e sacrifícios fúnebres, e ainda trevas, nevoeiro e obscuridade, ao passo que no céu tudo é luminoso, há muita ambrósia e néctar abundante. Por isso, parece mais agradável demorar-se entre eles. Daqui, da nossa companhia, ele parte voando, como se se evadisse de alguma prisão; mas quando está na hora de descer cá abaixo, vem vindo com todo o seu vagar, a passo lento ${ }^{238}$.

3. CLOTO - Ó Caronte, não fiques irritado, pois, como vês, ele já está perto e traz-nos muitas pessoas em grande ajuntamento, fazendo-as avançar com um cajado, como se fosse um rebanho de cabras. Mas... que é aquilo? Avisto, entre eles, um que vem amarrado, outro sempre a rir, e ainda um outro que traz um saco às costas e um cajado na máo, com um olhar duro e apressando os outros. Não vês também o próprio Hermes todo alagado em suor, com os pés cheios de pó, todo esbaforido e

${ }^{235}$ Hermes, que, ainda bebé (!), roubou o gado de Apolo, manteve (entre outros atributos) o pendor para se apropriar do alheio. Era o deus do comércio, dos negócios... e das inerentes trafulhices...

236 "só pela metade", pelo facto de ser "condutor de mortos", necro-

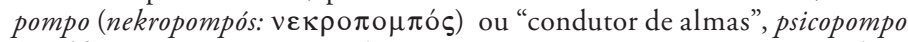
(psükhopompós: $\psi v \chi 0 \pi \circ \mu \pi o ́ \varsigma)$. Quanto ao resto, Hermes era um deus olímpico, mensageiro de Zeus, etc.

237 O asfódelo é uma "planta lilácea, de raiz tuberosa e belas flores ornamentais" ("Lello"). Julgo tratar-se de uma espécie de lírio.

238 "a passo lento", ou "a pé": Recorde-se que Hermes, como mensageiro dos deuses, tem asas nos pés e no capacete, o que torna a menção a passo ainda mais sugestiva da lentidão com que Hermes se deslocaria ao reino de Hades. 
com dificuldade de respirar pela boca?... Que é isso, ó Hermes? Que excitação é essa? Sim, pareces muito perturbado.

HERMES - Que é que há-de ser, ó Cloto, senão o caso deste patife, que queria fugir e que eu, ao persegui-lo, por pouco que náo me tornei hoje um desertor ${ }^{239}$.

CLOTO - Mas quem é ele? Porque é que tentava fugir?

HERMES - Evidentemente porque preferia antes viver. Trata-se de um rei ou um tirano, a julgar pelas suas lamúrias e gritos de dor, dizendo ter sido privado de uma enorme felicidade.

CLOTO - Entáo esse louco tentava fugir, como se pudesse continuar a viver, quando já tinha chegado ao fim o fio que lhe tinha sido fiado?

4. HERMES - “Tentava fugir", dizes tu? Se aqui este valente sujeito, o do cajado, náo me tivesse ajudado, e se náo o tivéssemos agarrado e amarrado, por certo que nos teria escapado. De facto, desde que Átropo ${ }^{240}$ no-lo entregou, durante todo o caminho resistia, puxava-nos para trás, arrastava os pés pelo chão, de modo que não era possível transportá-lo. Umas vezes rogava-me e suplicava-me que o largasse por uns momentos, prometendo dar-me mil e uma coisas. Eu, porém, como é natural, não acedi, vendo que ele me prometia o impossível. Mas quando já estávamos junto da entrada, e eu, como de costume, declarava a Éaco o número de mortos, e este o comparasse com a lista que lhe fora comunicada pela tua irmã ${ }^{241}$, o patife, sem nós darmos por isso, desapareceu. Faltava, pois, um morto em relação à lista, pelo que Éaco, franzindo as sobrancelhas, disse. "Ó Hermes, não uses com toda a gente essa tua arte da ladroagem; já te bastam essas brincadeiras lá no céu. Em matéria de mortos, trata-se de coisa exacta, não pode faltar nada. Como vês, a lista tem registados mil e quatro ${ }^{242}$ [mortos], ao passo que tu chegas aqui com um a menos... a não ser que me digas que Átropo fez mal a contagem." Então eu, perante tais palavras, pus-me todo vermelho e lembrei-me logo do que se

239 "desertor", ou "refractário", devia ter sentido idêntico ao de hoje: “aquele que não se apresenta ao serviço militar”.

240 Átropo, uma das três Parcas ou Meras (Moîrai: Mô̂ $\rho \alpha 1$ ); as outras são Cloto e Láquesis.

241 Átropo, acima mencionada.

242 "mil e quatro": Outros manuscritos (e editores modernos) lêem "quatro mil e quatro". De toda a maneira, e muito a propósito, trata-se de um número "bicudo", que serve para reforçar a ideia de exactidão. 
havia passado durante o caminho. E como, olhando à minha volta, não visse o fulano, logo me apercebi da sua fuga, pelo que me lancei em sua perseguiçấo o mais rápido que podia, pelo caminho que vai dar à luz. Aqui este bom amigo seguiu-me voluntariamente; lançados em corrida, como quando se abate a corda [de partida] ${ }^{243}$, apanhamos o sujeito já no Ténaro ${ }^{244}$. Mais um pouquinho, e conseguia escapar-nos.

5. CLOTO - E nós aqui, ó Caronte, já estávamos a condenar Hermes por negligência.

CARONTE - Então porque é que ainda perdemos tempo, como se não fosse já bastante o atraso?

CLOTO - Dizes bem. Que embarquem. Quanto a mim, de livro [de registo] na mão e sentada junto da escada [de embarque], como é habitual, procederei à identificação de cada um, à medida que embarca: quem ele é, donde vem e de que modo morreu. Tu [Caronte ${ }^{24}$ ], à medida que os vais recebendo, arruma-os e acomoda-os. E tu [Hermes] faz entrar primeiro aqui estes recém-nascidos. Sim, que é que eles poderiam responder-me?246

HERMES - Aqui estão eles, ó barqueiro, em número de trezentos, contando com os abandonados.

CARONTE - Mas que rica caçada! ${ }^{247} \mathrm{O}$ que me trazes são mortos muito verdes ${ }^{248}$.

${ }^{243} \mathrm{Na}$ linha de partida das corridas, punha-se um corda a certa altura, a qual, ao ser baixada, constituía o sinal de partida.

${ }^{244} \mathrm{O}$ Ténaro é um promontório na Lacónia, Peloponeso (hoje cabo Matapáo). Os antigos situavam aí mais uma das entradas para o reino de Hades.

245 Os mss. têm só “ e tu”, que alguns editores modernos entendem: “e tu, Hermes...”. Imediatamente a seguir, diz-se também “e tu...", que os editores entendem também como referido a Hermes. Quer dizer: os mss. náo explicitam, em ambos os casos, quem é o interlocutor de Cloto, mas parece razoável entender, sucessivamente, Caronte (com quem Cloto já estava a dialogar) e Hermes, novo interlocutor, cada um deles com sua função (v. texto).

246 Parece óbvio que os recém-nascidos embarcavam sem quaisquer formalidades.

247 "rica caçada": rica em sentido irónico = "fraca"; caçada em sentido figurado. É claro que as criancinhas não pagavam o óbolo que era obrigatório para os adultos. É disso que Caronte se queixa.

248 "verdes": O gr. diz (mortos que são como) "uvas (ainda) verdes": ac. pl. omphakias (ỏ $\mu \varphi \alpha \kappa i \alpha \varsigma)$... 
HERMES - Ó Cloto, queres que a seguir a estes embarquemos também os que não foram chorados?

CARONTE - Referes-te aos velhos? Sim, faz isso. Realmente, porque é que eu havia de ter problemas a examinar, agora!, coisas de antes de Euclides? ${ }^{249}$... Vocês, os que tiverem mais de sessenta nos, entrem já... Mas... que é isto? Não me prestam atenção, por terem os ouvidos entupidos pelos anos. Provavelmente, tens de carregar com eles e trazê-los.

HERMES - Ora aqui estáo estes quatrocentos menos dois $^{250}$, todos mirrados ${ }^{251}$, bem maduros e vindimados no tempo próprio ${ }^{252}$.

CARONTE - Agora sim, por Zeus!, já são [autênticas] passas de uva.

6. CLOTO - A seguir a estes, ó Hermes, traz-me cá os feridos. Mas em primeiro lugar, vós aí, dizei-me ${ }^{253}$ como morrestes, para virdes aqui parar... ou melhor, eu mesma vou observar-vos consultando a minha lista. Deviam ter morrido ontem na Média oitenta e quatro soldados, entre eles Oxiartes ${ }^{254}$, filho de Gobares.

${ }^{249}$ Em 403 a.C., depois de expulso de Atenas o governo espartano, restaurada, portanto, a democracia, havia "contas a saldar", ou seja, vinganças contra os "colaboracionistas" do ocupante. Para evitar mais tumultos, o arconte Euclides propôs e fez aprovar uma amnistia (amnēstía: $\alpha \mu \nu \eta \sigma \tau i ́ \alpha$ ), lit. "e "esquecimento", segundo a qual era proibido proceder judicialmente por actos cometidos antes da promulgação da lei. A expressão "(isso foi) antes de Euclides" ganhou, também, o sentido de "coisa já muito antiga"... "águas passadas"...

250 "quatrocentos menos dois", forma mais expedita de dizer, analiticamente, trezentos e noventa e oito, que o gr. exprime geralmente em ordem inversa da nossa, ou seja, lit. . ", "oito e noventa e quatrocentos": oktố

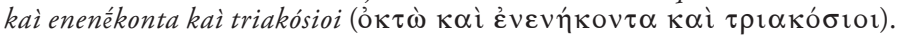
A título de... brincadeira, o francês diz trois cent quatre-vingt-dix-huit...

251 "mirrados", ou "secos", é um dos sentidos dados nos dicionários; outros entendem "tenros", "moles", mas o contexto (v. a seguir) alude a "passas de uva”, astaphides ( $\alpha \sigma \tau \alpha \varphi \hat{i} \delta \varepsilon \varsigma)$, o que aponta para o primeiro sentido.

252 vindimados no tempo próprio, ou seja, que náo morreram prematuramente, os velhos, ao contrário dos que se seguem...

253 “dizei-me", i. é, diga-me cada um de vós [sucessivamente]: dirige-se aos outros mortos em geral, mas a seguir emenda o processo de verificação...

254 "Oxiartes, filho de Gobares", perfeitos desconhecidos para nós, mas talvez não para Luciano. Em todo o caso, este acrescento de Cloto dá um certo ar de precisão à... contabilidade. 
HERMES — Já aqui estão.

CLOTO - Sete suicidaram-se por amor, entre eles o filósofo Teágenes ${ }^{255}$, por causa daquela prostituta de Mégara.

HERMES - Esses estão aí ao pé de ti.

CLOTO - Onde estáo os que se mataram mutuamente ao disputarem o trono?

HERMES - Já aqui estão.

$\mathrm{CLOTO}-\mathrm{E}$ aquele que foi assassinado pela própria mulher e pelo amante desta?

HERMES - Ei-lo aí a teu lado.

CLOTO - Traz também os condenados em tribunal, quer dizer, os [que morreram] flagelados ou empalados. E então os dezasseis que foram mortos por assaltantes, onde estão eles, ó Hermes?

HERMES - Ei-los, esses feridos que aí vês... Queres que traga de uma só vez também as mulheres?

CLOTO - Com certeza, e também em grupo os que morreram num naufrágio, pois morreram todos do mesmo modo: e os que morreram de febre, também todos juntos, e com eles o médico Agátocles...

7. Mas... onde está o filósofo Cinisco, que devia morrer, depois de comer o jantar de Hécate e os ovos lustrais ${ }^{256}$, e em cima disso um choco $\mathrm{Cru}^{257}$.

CINISCO - Ó querida Cloto, há já muito tempo que estou junto de ti. Que mal fiz eu, para tu me deixares lá em cima todo este tempo? Na verdade, fiaste-me quase todo um fuso. E no entanto, muitas vezes tentei quebrar o fio e partir, mas, não sei lá como, o fio era inquebrável.

CLOTO - É que eu fui-te deixando ficar como observador e médico das coisas humanas... Mas embarca lá, e boa sorte!

255 Teágenes: Não deve tratar-se da mesma pessoa mencionada em $A$ Morte de Peregrino. Os contemporâneos de Luciano saberiam de quem se tratava. Para o caso, pouco importa...

${ }^{256} \mathrm{O}$ jantar de Hécate e os ovos lustrais (dos sacrifícios de purificação) eram colocados nas encruzilhadas, para que a Deusa os ingerisse. É claro que os pobres aproveitavam-se da ocasião... Neste passo, refere-se um filósofo cínico, o qual, naturalmente, não tinha o mínimo respeito pela terrível deusa.

257 Conta-se que o filósofo cínico Diógenes morreu depois de comer um choco cru, no que, ao que parece, terá sido imitado por um colega de ideologia. 
CINISCO - Mas não, por Zeus!, sem primeiro termos embarcado aqui este tipo amarrado. $\mathrm{Na}$ verdade, receio que ele te seduza com as suas preces.

8. CLOTO - Vejamos quem ele é.

CINISCO ${ }^{258}$ — É Megapentes, filho de Lacides... um tirano. CLOTO - Vamos, embarca!

MEGAPENTES - Oh não, minha Senhora Cloto, mas antes deixa-me ir lá acima por um pouquinho de tempo. Depois eu próprio virei espontaneamente, sem que ninguém me chame.

CLOTO - E por que motivo pretendes ir lá acima?

MEGAPENTES - Permite-me que primeiro termine o meu palácio, pois a construção ficou semiacabada.

CLOTO — Estás doido! Vamos, embarca!

MEGAPENTES - Suplico-te, ó Moira ${ }^{259}$, não é por muito tempo. Permite-me que fique lá um único dia, o suficiente para indicar uma coisa à minha mulher a respeito dos meus bens, quer dizer, onde tinha enterrado um enorme tesouro.

CLOTO - É coisa decidida, não conseguirás nada.

MEGAPENTES - Será que vai perder-se tanto ouro?

CLOTO - Não vai perder-se, não, fica sossegado, pois o teu primo Mégacles vai apoderar-se dele.

MEGAPENTES - Oh que ultraje! O quê? O meu inimigo, que eu, por incúria, não matei antes disso?

CLOTO - Esse mesmo. E há-de sobreviver-te quarenta anos... e mais um pouquito, depois de se apoderar das tuas concubinas, das tuas roupas e de todo o teu ouro.

MEGAPENTES - Ó Cloto, como tu és injusta, ao distribuíres as minhas coisas pelos meus maiores inimigos!

CLOTO - Então e tu, meu valentão, não te apoderaste do que pertencia a Cidímaco, depois de o matares a ele e de, a seguir, chacinares os seus filhos enquanto ele ainda respirava?

MEGAPENTES - Mas agora esses bens eram meus.

CLOTO - Pois bem: O teu tempo de os possuíres acaba de chegar ao fim.

${ }^{258}$ É esta a atribuição dos mss. $\Gamma$; outros atribuem a fala a Hermes ou a uma nova personagem, o tirano Megapentes...

${ }^{259}$ Moira (Mô̂ $\left.\rho \alpha\right)$, na adaptaçáo regular ao port. deve ser Mera, forma que, uma vez (ou algumas mais vezes) sem exemplo, transcrevo do grego, em vez de proceder à adaptação "canónica"... 
9. MEGAPENTES - Ó Cloto, escuta aqui uma coisa que quero dizer-te em particular... (Vós aí, afastai-vos um pouco $)^{260} \ldots$ Se me deixares fugir, prometo entregar-te ainda hoje mil talentos ${ }^{261}$ em ouro cunhado.

CLOTO - É o quê? Ainda conservas na memória, ridícula criatura, o ouro e os talentos?

MEGAPENTES - E ainda acrescentarei, se quiseres, aquelas duas crateras de que me apoderei depois de ter morto Cleócrito, cada uma das quais levanta ${ }^{262}$ cem talentos $^{263}$ de ouro fino.

CLOTO - Levantem-no, pois não parece querer embarcar voluntariamente.

MEGAPENTES - Invoco-vos como testemunhas: A muralha está inacabada, bem como o arsenal. Para que estas obras fiquem prontas, bastar-me-á viver somente mais cinco dias.

CLOTO - Não te preocupes, que outro construirá a muralha.

MEGAPENTES - Nesse caso, peço-te um favor, de todo em todo razoável.

CLOTO - Que favor?

MEGAPENTES - O de viver o tempo suficiente para submeter os Písidas, para impor um tributo aos Lídios e para erigir um enorme monumento à minha pessoa, no qual

260 "Vós aí, afastai-vos um pouco": Frase dirigida a outros, especialmente a Hermes e Caronte. Alguns editores atribuem esta parte a Cloto, o que poderia aceitar-se, mas não é de modo nenhum obrigatório.

${ }^{261} \mathrm{O}$ talento não era uma moeda propriamente dita, mas uma «moeda de conto" (cf. contos de réis) = 60 minas; uma mina = 100 dracmas; uma $\mathrm{dracma}=6$ óbolos. Portanto, um talento $=6000$ dracmas. Neste passo, trata-se de uma grande soma, pois mil talentos (ainda por cima de ouro) equivalem a sessenta mil minas (60.000: um cavalo de raça andava pelas 12 minas!) ou seis milhóes de dracmas (6.000.000). O tirano oferecia a Cloto um autêntico... "balúrdio".

262 "levanta”, ou seja, "pesa”. Trata-se da imagem dos dois pratos da balança. em que a cratera, num dos pratos, equilibra o outro com o mesmo peso. Traduzi por "levanta”, porque, logo a seguir, o verbo é usado no seu sentido mais habitual: "Levantem-no", i. é, "arrastem-no".

263 O talento, além do valor monetário, era também uma unidade de peso, c. 35-37 kg (com diversas variantes locais). Claro que o valor monetário equivalente dependia de o talento ser considerado em prata ou em ouro (este mais ou menos puro). Neste caso, cada cratera pesaria c. de... $35 \mathrm{~kg}$ x $100=3.500 \mathrm{~kg}($ !). Nitidamente, tal como com a promessa de "mil talentos” (v. supra), quem, numa situação desesperada, promete mundos e fundos não tem... nem perto nem longe... 
inscreverei todas as grandes façanhas e actos guerreiros que cometi durante a minha vida.

CLOTO - Ó homem, o que tu pedes não é coisa para um só dia, mas para um período de cerca de vinte anos.

10. MEGAPENTES - Mas estou pronto a dar-vos uma caução pelo meu rápido regresso. Se assim o entenderdes, entregar-vos-ei, como homem por homem, o meu querido filho.

CLOTO - Ó meu patife, aquele que tu tantas vezes ansiaste por deixar na terra [como teu sucessor]?

MEGAPENTES - Isso por que ansiei já foi há muito tempo. Agora vejo melhor as coisas.

CLOTO - Mas ele virá para cá dentro de pouco tempo, assassinado pelo novo rei.

11. MEGAPENTES - Mas, pelo menos, ó $M o i r a^{264}$, não me recuses uma coisa.

CLOTO - Que coisa?

MEGAPENTES - Quero saber como se passarão as coisas depois da minha morte.

CLOTO - Então vai ouvindo, pois, ao tomares conhecimento, ficarás ainda mais aflito. $\mathrm{O}$ teu escravo Midas casará com a tua mulher... aliás, desde há muito que ele era seu amante.

MEGAPENTES - Que grande malandro! E eu que, persuadido por ela, lhe concedi a liberdade!

CLOTO - A tua filha será inscrita entre as concubinas do actual tirano; e os bustos e estátuas que a cidade durante muito tempo erigiu em tua honra serão derrubadas e servirão de risota para os espectadores.

MEGAPENTES - Diz-me cá: De entre os meus amigos, não haverá nem um que fique indignado com esses actos?

CLOTO - Mas quem é que era teu amigo? E por que motivo se tornara tal? Então não sabes que aqueles que se ajoelhavam aos teus pés, elogiando cada uma das coisas que tu dizias ou fazias, agiam quer por medo, quer por esperança, amigos, sim, mas do teu poder e só olhando às oportunidades?

MEGAPENTES - E no entanto, nos banquetes, ao fazerem libaçóes, desejavam-me, em altas vozes, muitas e grandes

${ }^{264}$ Repito a nota a Moira, do $\$ 8$ : Moira (Mô̂ $\left.\rho \alpha\right)$, na adaptação regular ao port. deve ser Mera, forma que, uma vez (ou algumas mais vezes) sem exemplo, transcrevo do grego, em vez de proceder à adaptação "canónica”... 
felicidades, cada um deles afirmando-se pronto a morrer, se fosse preciso, no meu lugar... enfim, só juravam pelo meu nome $e^{265}$.

CLOTO - E no entanto, foi em casa de um deles que tu morreste ontem, depois do jantar. De facto, foi a última taça que te deram a beber, que te mandou para cá.

MEGAPENTES - Por isso é que eu me apercebi de um certo gosto amargo... Mas porque é que ele me fez aquilo?

CLOTO - Fazes perguntas a mais. Vamos, já devias ter embarcado.

12. MEGAPENTES - Mas ainda há uma coisa, ó Cloto, que me está particularmente atravessada na garganta, pela qual muito desejaria dar uma espreitadela lá acima, nem que fosse por um instante.

CLOTO - E que coisa é essa? Na verdade, parece tratar-se de algo muito importante.

MEGAPENTES - O meu criado Cárion, logo que me viu morto, entrou, pela tardinha, na câmara onde eu jazia e, aproveitando-se da ocasiáo (pois ninguém estava a guardar-me), levou para lá a minha concubina Glicério ${ }^{266}$, com quem — julgo eu - já desde há muito tinha relaçôes, e tendo fechado a porta, deu-lhe uma valente "esfrega" 267 , como se ninguém estivesse presente. Então, depois de satisfazer o desejo, olhou para mim e disse: "Tu, homenzinho repugnante, deste-me pancada muitas vezes, sem eu ter feito qualquer mal"; e ao mesmo tempo que dizia estas palavras, arrepelava-me a barba e dava-me bofetôes na cara; por fim, puxando da goela um enorme escarro, cuspiu-me em cima, dizendo: "Vai-te para o sitio dos impios". E dizendo estas palavras, saiu. Eu bem me inflamei [de raiva], mas não podia fazer-lhe nada, pois já estava inteiriçado e frio.

265 "só juravam pelo meu nome", i. é., considerando-me um deus...

${ }^{266}$ Glicério, gr. Glükérion ( $\left.\Gamma \lambda v \kappa \varepsilon ́ \rho \imath o v\right)$ é um diminutivo-hipocorístico em -ion, sufixo que pode formar acrescentar-se a antropónimos ou ginecónimos, com o sentido de ...-inho; aqui, teríamos Glicerinha, ou seja, Docinha, ou, já agora, Dulcinha... Do ponto de vista do port., náo fica muito elegante (ainda que seja a regra) verter o nome com a terminaçáo -o e o género feminino: a Glicério.

267 A personagem (Luciano, afinal) utiliza um eufemismo, em vez do termo próprio, bineîn ( $\beta \imath v \varepsilon \hat{\imath} v)$, provavelmente inspirado em Aristófanes (e certamente outros comediógrafos). O verbo spodéo ( $\sigma \pi \mathrm{o} \delta \varepsilon \dot{\varepsilon} \omega)$ significa, propriamente, "reduzir a pó", "esmagar", o que nos permite traduzir por "deu-lhe uma valente esfrega", que o contexto dirige para o sentido sexual. 
A malvada da rapariga, ao sentir o ruído de pessoas que se aproximavam, humedeceu os olhos com saliva, como se estivesse a chorar por mim, e retirou-se a soluçar e a pronunciar o meu nome. Ah! Se eu os apanhasse...

13. CLOTO - Deixa-te de ameaças e embarca, que já é tempo de te apresentares no tribunal.

MEGAPENTES - Mas quem se atreverá a lançar o seu voto contra um tirano? ${ }^{268}$

CLOTO - Contra um tirano, ninguém, é claro, mas contra um morto, Radamanto, que tu vais ver agora mesmo, juiz justo, que impóe a cada um a pena que ele merece. Bem, agora não causes mais atrasos.

MEGAPENTES - Ó Moira, faz de mim um tipo do povo, um desses pobres, um escravo, em vez do rei que outrora fui, mas pelo menos deixa-me voltar à vida.

CLOTO - Onde está o tipo do cajado? E tu, Hermes, trá-lo cá para dentro, arrasta-o por um pé, pois ele não embarcará por sua livre vontade.

HERMES - Segue-me, fujāo; e tu, barqueiro, toma conta dele... e... aquela coisa ${ }^{269}$... para maior segurança...

CARONTE - Não te dê cuidado, vais ser amarrado ao mastro.

MEGAPENTES - Mas a mim compete-me ficar em lugar de honra... ${ }^{270}$

CLOTO - E porquê?

MEGAPENTES — Por Zeus!... Porque eu era um tirano e tinha dez mil ${ }^{271}$ guarda-costas.

CINISCO - Então não é que Cárion teve toda a razão em te arrepelar a barba, meu estúpido? Pois vais ter uma tirania bem amarga, provando do meu cajado...

${ }^{268}$ Nos tribunais terrestres (e, naturalmente, também nos infernais), cada jurado recebia duas rodelas de bronze, uma das quais estava furada no centro, significando condenação, enquanto a outra estava inteira, significando absolvição.

269 "aquela coisa": Hermes e Caronte, como velhos conhecidos, aplicam o dito (port.): Para bom entendedor...

270 "lugar de honra” ou "presidência" (proedria: $\pi \rho \circ \varepsilon \delta \rho i ́ \alpha)$, era o lugar do "presidente" (próedros: $\pi \rho \varepsilon_{\varepsilon} \delta \rho \circ \varsigma$ ), nas assembleias, nos tribunais, nos banquetes... e no navio dos mortos...

271 “dez mil” é o número que está no texto, mas a palavra também tem o chamado valor indeterminado (cf. port. mil e um; com seiscentas pipas!, etc.). 
MEGAPENTES - Será que Cinisco se atreverá a levantar o cajado contra mim? Mas não estive eu, ainda ontem, quase a empalar-te, por teres sido demasiado desbragado [de língua], muito rude e muito crítico?

CINISCO $^{272}$ - Pois tu é que vais ficar amarrado ao mastro.

14. MICILO - Diz-me cá, ó Cloto: então e a meu respeito nem uma só palavra? Será que é por eu ser pobre, que tenho de embarcar em último lugar?

CLOTO - Mas quem és tu?

MICILO - Sou o sapateiro Micilo.

CLOTO - Estás então zangado com o atraso? Não vês quantas coisas promete dar-me aqui o tirano, se eu o deixar ir só por pouco tempo? Por isso, causa-me admiração que essa demora não te seja agradável.

MICILO - Escuta, ó tu, a mais excelente das Moiras: Não me consola muito o famoso favor do Ciclope, quando prometia: "Devorarei Ninguém ${ }^{273}$ em último lugar." É que, quer seja o primeiro, quer seja o último, os mesmos dentes $\mathrm{me}^{274}$ esperam. Aliás, a minha situação não é igual à dos ricos; na verdade, as nossas vidas são, como sói dizer-se, diametralmente opostas: o tirano, que, enquanto vivo, parecia feliz, temido e admirado por toda a gente, agora, ao deixar tanto ouro e tanta prata, tanta roupa e tantos cavalos, tantos banquetes, belos rapazinhos e formosas mulheres, é claro que ficou triste e amargurado, ao ver-se privado desses bens. Na verdade, náo sei lá como, a alma fica pegada a tais bens como a um visco, e não se deixa facilmente separar deles, uma vez que desde há muito se fundiu ${ }^{275}$ com esses bens, ou melhor, é como que um grilhão inquebrável com que lhes aconteceu terem sido atados. Mesmo que alguém os arraste à força, não adianta: eles que antes eram táo corajosos, gritam e suplicam, e revelam-se uns

272 Outros atribuem esta fala a Cloto.

273 "Ninguém" foi o nome que Ulisses deu ao Ciclope, prevendo que, mais tarde, os outros ciclopes, ao ouvi-lo gritar de dor, lhe perguntariam se algum mortal estava a roubar-lhe o rebanho ou a querer matá-lo, ao que o Ciclope responderia: "Ninguém me mata pelo dolo ou pela violência." Perante esta resposta, os ciclopes ficaram mais tranquilos e retiraram-se...

274 “me esperam", referido, por comparação, a Micilo, mas também “o esperam”, aludindo a Ulisses (a Ninguém).

275 "se fundiu" é tradução literal; poderíamos entender, figuradamente, "se identificou com...". 
cobardes no caminho que conduz ao Hades. Tentam voltar atrás, e, tal como os amantes infelizes, querem olhar, nem que seja de longe as coisas [que deixaram] na vida, como fazia aquele [tipo] presunçoso, que, durante o caminho, tentou evadir-se e, agora aqui, te incomodava com súplicas. Eu, porém, que não tinha nada de meu na vida - nem uma granja, nem uma casa, nem ouro, nem mobília, nem reputação, nem estátuas —, estava pronto para partir, pelo que, assim que Átropo me fez sinal, eu, todo contente, atirei fora o trinchete ${ }^{276}$ e a sola (nesse momento, tinha entre mãos uma bota), dei logo um salto para o ar e, mesmo descalço e sem limpar a graxa [das mãos], fui atrás dela, ou melhor, passei-lhe adiante, sempre olhando em frente. Na verdade, nada do que deixava para trás me fazia virar-me, nada chamava por mim.

15. E, por Zeus!, agora verifico que aqui entre vós tudo funciona bem: $O$ facto de todos estarem em pé de igualdade e de ninguém ser diferente do vizinho, é a coisa que eu acho mais deliciosa. Deduzo que aqui os credores não vêm reclamar as dívidas, que ninguém vem cobrar impostos e - o mais importante de tudo - as pessoas não ficam enregeladas no Inverno, não adoecem nem são sovadas pelos mais poderosos. Todos vivem em paz, as coisas estão viradas ao contrário: Nós, os pobres, rimos, ao passo que os ricos se afligem e se lamentam.

16. CLOTO - Já há muito, ó Micilo, que te vejo a rir. Que é que te faz rir assim tanto?

MICILO - Ora escuta lá, tu, para mim a mais respeitável das deusas? Lá em cima, eu morava perto do tirano, pelo que via perfeitamente o que se passava em sua casa; ele afigurava-se-me então alguém igual aos deuses; considerava-o feliz, ao ver o esplendor da sua [faixa de] púrpura ${ }^{277}$, a multidão de acompanhantes ${ }^{278}$, o ouro, as taças cravejadas de pedras preciosas e os leitos com pés de prata; além disso, o odor dos cozinhados para

276 "trinchete": faca de sapateiro.

${ }^{277}$ Os senadores e os cavaleiros romanos usavam, nas túnicas, uma faixa de púrpura, mais larga para os primeiros, e mais estreita para os segundos.

278 Referência ao grande senhor, patronus, que se fazia acompanhar dos seus clientes e criados. Embora se aluda (tal como no caso supra: v. nota a púrpura) ao caso romano, Luciano tinha também (ou sobretudo?) em mente os tiranos orientais. 
o jantar punha-me doido; assim, afigurava-se-me um super-homem ${ }^{279}$, uma pessoa três vezes feliz ${ }^{280}$, mais belo e mais alto que qualquer outro homem, por uma diferença de um côvado real $^{281}$, exaltado pela Fortuna, caminhando majestosamente, de cabeça inclinada para trás ${ }^{282}$, deslumbrando todos por quem passava. Todavia, uma vez morto, olhei-o como um tipo ridículo, despojado daquele fausto; e ria sobretudo de mim, por ter admirado uma tal porcaria, por ter julgado a sua felicidade pelo odor ${ }^{283}$, por tê-lo felicitado pelo sangue dos moluscos ${ }^{284}$ do mar Lacónico.

17. Ao ver não só este tipo, mas também o agiota Gnífon a gemer e a arrepender-se de não ter gozado do seu dinheiro, e de ter morrido sem o ter "provado", deixando os seus bens ao esbanjador Rodócares - que era o seu parente mais próximo e foi o primeiro, segundo a lei, a ser chamado para ficar com a herança - , não fui capaz de conter as gargalhadas, especialmente ao recordar como o fulano andava sempre macilento e de aspecto miserável ${ }^{285}$, com a cabeça cheia de preocupaçóes e rico, sim, mas só nos dedos, com os quais contava talentos ${ }^{286} \mathrm{e}$ miríades, amealhados a pouco e pouco, e que brevemente irão ser esbanjados pelo afortunado Rodócares... Mas... porque é

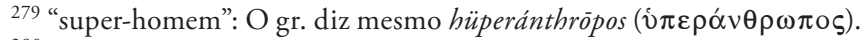

280 "três vezes feliz", ou seja, "felicíssimo". Traduzi à letra trisólbios ( $\left.\tau \rho \imath \sigma o ́ \lambda \beta \imath \varsigma_{\varsigma}\right)$. Ocorreu-me o passo da Eneida (I, 94): ... O terque quaterque beati..., “ó [vós] três e quatro vezes felizes..." (ou seja: aqueles a quem coube em sorte morrer ante as muralhas de Tróia).

${ }^{281} \mathrm{O}$ valor dos pesos e das medidas variava localmente. Aqui, côvado náo pretende ser uma medida exacta; em todo o caso, diga-se que, em Roma (cubŭtus), equivalia a c. de $0,444 \mathrm{~cm}$. O côvado real tinha mais 2 dedos (c. $4 \mathrm{~cm}$ ). Tamanha precisão significa mesmo... imprecisão.

282 É difícil incluir, numa só palavra, todas as conotaçôes: o homem caminhava de cabeça alta, inclinada para trás, mas (naturalmente) olhando para o lado enquanto caminhava para a frente, enfim, uma "pose" extremamente orgulhosa...

283 "pelo odor", ou seja, o odor dos cozinhados, acima referido.

${ }^{284}$ Trata-se de moluscos gastrópodes, com que se fabricava a púrpura.

285 "de aspecto miserável"; outros sentidos (v. dics.): "seco", donde "magro", "escanzelado"; "sujo", "encardido"; "mal arranjado", "desgrenhado", etc... É difícil escolher.

${ }^{286}$ Recorde-se que um talento equivalia a 60 minas ou a 6.000 dracmas; uma "miríade" é o número de 10.000, neste caso "dez mil dracmas". É claro que ambos os termos se referem a unidades de conto, e náo a moedas reais (cf. port. "vinte contos de réis"). 
que não zarpamos já? Sim, enquanto navegamos, rir-nos-emos do resto, vendo aqueles tipos a lamuriarem-se.

CLOTO - Vá lá, sobe, para que o barqueiro ice a âncora.

18. CARONTE - Ó tu aí, aonde é que vais? A barca já está cheia. Espera aí até amanhã. Passar-te-emos logo de madrugada.

MICILO - Ó Caronte, fazes mal em deixar para trás um morto que já começa a cheirar mal ${ }^{287}$. Fica sabendo que te processarei no tribunal de Radamanto, por violação da lei... Mas que grande desgraça! Já estão a navegar, e "eu vou ficar aqui sozinho e abandonado" ${ }^{288}$... Mas... porque náo atravessar a nado atrás deles? Na verdade, não tenho medo de me afogar por falta de forças, pois morto já eu estou. Aliás, nem sequer tenho um óbolo para pagar a passagem ${ }^{289}$.

CLOTO - Que vem a ser isso, ó Micilo? Não te é lícito passar dessa maneira.

MICILO - Mesmo assim, talvez chegue a terra antes de vós.

CLOTO - De maneira nenhuma, mas antes, rememos em frente $^{290}$ e agarremo-lo. E tu, Hermes, puxa-o cá para cima.

19. CARONTE - Então e agora onde é que ele se sentará? Os lugares, como vês, estão todos ocupados.

HERMES - Sobre os ombros do tirano, se achas bem.

CLOTO - Hermes teve uma boa ideia.

CARONTE $^{291}$ - Sobe lá então e finca os pés no cachaço do meliante. E quanto a nós, que façamos boa viagem.

CINISCO — Ó Caronte, é bom que, desde já, te conte a verdade: Eu não poderei pagar-te o óbolo no momento do desembarque. De facto, não possuo nada, a não ser o alforge, que estás a ver, e este cajado. No entanto, se quiseres, estou pronta para escoar a água ou dar ao remo. Não terás razão de queixa, desde que me dês um remo fácil de manobrar e bem forte.

CARONTE - Então rema, pois esse trabalho será pagamento bastante.

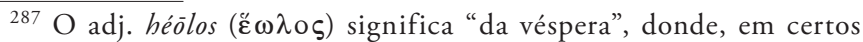
contextos, "estragado", "deteriorado" (alimentos...).

288 Julga-se que a frase é uma citação de um verso de comédia... a menos que se trate de simples casualidade...

289 A sequência do diálogo mostra que Micilo se lança mesmo à água.

${ }^{290}$ Como se lê, Micilo já ultrapassara a barca, pelo que era preciso forçar um pouco a marcha desta, a fim de o agarrar.

${ }^{291}$ Alguns editores continuam a atribuir esta fala a Cloto, 
CINISCO — Não vai ser necessária uma canção de remador?292

CARONTE - Sim, por Zeus!, se é que conheces alguma canção de marinheiro.

CINISCO - Sei, sim, e muitas, ó Caronte... Mas, como vês, estes aqui sobrepóem ao nosso som [o som] do seu choro, e assim o canto vai ficar perturbado.

\section{MORTOS -}

- Ai de mim!... As minhas riquezas!

- Ai de mim!... Os meus campos!

- Ai!... A bela casa que eu deixei!

- Quantos talentos vai apanhar e esbanjar o meu herdeiro!

- Ai dos meus filhinhos bebés!

- Quem vindimará as minhas vinhas, que eu plantei o ano passado?

HERMES - Então e tu, ó Micilo, não te lamentas de nada? E no entanto, não é lícito que uma pessoa faça a travessia sem verter lágrimas.

MICILO - Deixa lá! Com esta tão bela viagem, não tenho nada de que me lamentar.

HERMES - Mesmo assim, lamenta-te nem que seja um pouquito, só para cumprir a tradição.

MICILO — Nesse caso, ó Hermes, já que assim o queres, vou lamentar-me. Ai os meus couros! Ai as minhas velhas botas! Ai as minhas podres sandálias! De agora em diante, infeliz de mim, já não ficarei em jejum de manhã até à noite, nem caminharei descalço e seminu no Inverno, batendo o dente com frio. Quem ficará com o meu trinchete e a minha sovela?

HERMES ${ }^{293}$ - Basta de lamentaçôes. Já estamos quase no fim da viagem.

21. CARONTE - Vamos, paguem primeiro a passagem. Tu também, dá cá! ${ }^{294}$ Bem já recebi de toda a gente... E tu, Micilo, paga também o óbolo.

292 Trata-se de canções adequadas a marcar o ritmo da remação.

293 Alguns editores continuam a atribuir esta fala a Micilo.

294 “tu também, dá cá": É óbvio que (ao contrário do que alguns entendem) Caronte se dirige, não a Micilo (ao qual se dirige a seguir), mas a algum passageiro mais "distraído"... ou que se fazia tal. 
MICILO - Estás a brincar, ó Caronte, ou então, como sói dizer-se, "estás a escrever na água" 295 , se esperas receber algum óbolo de Micilo. É que não faço a mínima ideia se o óbolo é quadrado ou redondo.

CARONTE - Mas que bela e lucrativa viagem, esta de hoje! ${ }^{296}$. Vamos, desembarquem, que eu vou buscar cavalos, bois, cães e outros animais, pois eles também têm de atravessar.

CLOTO - Toma conta deles e condu-los, ó Hermes, que eu própria vou regressar à outra margem, a fim de trazer os Seres $^{297}$ Indópates ${ }^{298}$ e Heramitres, que morreram lutando um com o outro por uma questão de fronteiras.

HERMES - Avancemos, meus senhores, ou melhor, sigam-me todos em fila.

22. MICILO - Por Héracles! Que escuridão! Onde está agora o belo Megilo? Ou como distinguir, aqui, se Símique ${ }^{299}$ é ou não mais formosa que Frine? De facto, tudo aqui é igual, tudo tem a mesma cor, nada é belo, ou mais belo, mas até mesmo este meu manto, que antes me parecia feio, fica igual ao manto de púrpura do rei, já que ambos são invisíveis e imersos nas mesmas trevas... Ó Cinisco, onde raio estás tu?

CINISCO - Estou aqui, Micilo, onde te falo. Então, se assim te aprouver, caminhamos juntos.

MICILO - Dizes bem. Dá-me a tua mão direita... Ora diz-me cá - pois é claro que tu, Cinisco, foste iniciado nos mistérios de Elêusis —, não te parece isto aqui igual ao que era lá em cima?

CINISCO — Tens razão. Eis que se aproxima uma mulher com um facho na mão, de olhar terrível e ameaçador... Será que se trata de uma Erínia? ${ }^{200}$

MICILO - Pelo menos assim parece, a julgar pelo aspecto.

295 “estás a escrever na água”, bela imagem, para significar um esforço vão.

${ }^{296}$ Caronte refere-se, não tanto ao facto de dois passageiros (Cinisco e Micilo) não pagarem, mas, sobretudo ao facto de, devido a atrasos vários, só ter feito uma travessia.

297 "Seres”, povo asiático, para lá do Ganges e muito mal conhecidos, talvez mesmo chineses...

${ }^{298}$ Indópates ou (segundo outros) Indópatres...

299 Símique e Frine eram duas famosas (e formosas) cortesãs...

300 As Erínias (ou Fúrias) eram divindades infernais, em número de três: Alecto, Megera e Tisífone. Neste passo, trata-se de Tisífone. 
23. HERMES - Recebe estes, ó Tisífone; são mil e quatro. TISÍFONE - Há já muito tempo que aqui o Radamanto vos espera.

RADAMANTO - Trá-los cá, Erínia. E tu, Hermes, anuncia-os e convoca-os.

CINISCO - Ó Radamanto, pelo teu Pai!, chama-me e examina em primeiro lugar o meu caso.

RADAMANTO - E por que motivo?

CINISCO - Quero sobretudo acusar um certo tirano ${ }^{301}$, pelos crimes que eu sei que ele cometeu durante a vida. $\mathrm{O}$ meu testemunho não seria digno de crédito, se previamente eu não revelasse quem eu sou e de que modo vivi.

RADAMANTO - Então quem és tu?

CINISCO - Sou Cinisco, meu caro, filósofo de profissão.

RADAMANTO - Ora aproxima-te e apresenta-te ao tribunal em primeiro lugar. E tu, Hermes, chama os acusadores.

24. HERMES - Se há aqui alguém que queira acusar Cinisco, que avance.

CINISCO - Ninguém se apresenta.

RADAMANTO — Mas isso não basta, ó Cinisco. Despe-te lá, para que te avaliemos com base nos estigmas [do teu corpo ${ }^{302}$.

CINISCO - Como é que eu me tornei um estigmatizado?

RADAMANTO - Por cada uma das más acçóes que qualquer de vós tenha praticado durante a vida, são marcados na sua alma estigmas invisíveis.

CINISCO - Pronto, já estou completamente nu, portanto procura esses tais estigmas de que falas.

RADAMANTO — Este homem está completamente limpo, com excepção destas três ou quatro marcas muito leves e apagadas... Mas que é isto? Vêem-se muitas cicatrizes e sinais de queimaduras, mas, não sei porquê, já muito safadas, ou

301 "um certo tirano": Os mss. dizem apenas "um certo" (homem, fulano? ou, mais precisamente, como alguns entendem, tirano). Como, porém, no fim do $\$ 24$, se fala, do tirano, é de supor que Radamanto já saberia, por este passo, que se tratava de um tirano.

302 "estigmas" (no corpo), stígmata $(\sigma \tau i \gamma \mu \alpha \tau \alpha)$ : Cinisco vai entender a palavra no sentido de marcas feitas com um ferro em brasa, com que se indicava que determinado individuo era um mau escravo, um escravo "marcado" ou "estigmatizado", stigmatias ( $\sigma \tau \imath \gamma \mu \alpha \tau i \alpha \varsigma)$. Afinal, era outra coisa, como Radamanto explicará a Cinisco (que não sabia!)... e a nós. 
melhor, arrancadas. Como é isso, ó Cinisco? Como é que ficaste perfeitamente limpo?

CINISCO - Vou explicar-te. Em tempos, por ignorância, eu era muito mau, e por isso ganhei muitos estigmas. Assim, porém, que comecei a dedicar-me à filosofia, limpei, a pouco e pouco, todas as nódoas da alma.

RADAMANTO - Este tipo utilizou um remédio muito bom e muito eficaz. Pois vai para as ilhas dos Bem-Aventurados, a fim de conviveres com as pessoas virtuosas... mas só depois de teres acusado esse tal tirano de que falas ${ }^{303}$. Hermes, chama outros.

25. MICILO - Ó Radamanto, o meu caso é muito rápido e requer apenas um curto exame. Já desde há muito que estou despido, por isso inspecciona-me.

RADAMANTO - Quem és tu?

MICILO - Sou o sapateiro Micilo.

RADAMANTO - Muito bem, Micilo, estás completamente limpo e sem estigmas. Vai também tu para junto aqui do Cinisco. Hermes, chama já o tirano.

HERMES - Apresente-se Megapentes, filho de Lacides. Aonde vais tu? Vem cá, é a ti, o tirano, que eu estou a chamar... Agarra-o, Tisífone, e trá-lo para cá arrastado pelo pescoço.

RADAMANTO - Tu, Cinisco, produz já a acusação e as provas, que o homem já está na tua frente.

26. CINISCO - No fundo, nem seriam precisas palavras, pois ficarás imediatamente a saber muito bem que espécie de tipo ele é, a julgar pelos estigmas. No entanto, eu próprio vou revelar-te o homem [que ele é] e, através das minhas palavras, mostrar-to mais claramente. De facto, entendo deixar de lado o que este grandessíssimo tratante fez enquanto cidadão comum. Mas depois de se ligar a tipos extremamente arrogantes, de ter agregado a si uns capangas e de se ter revoltado contra o Estado, proclamou-se tirano e assassinou indiscriminadamente mais de dez mil cidadáos, apoderou-se das fortunas de cada um deles e, tendo chegado ao cúmulo da riqueza, não se coibiu de nenhuma forma de depravação, antes se entregando a todas as crueldades e ultrajes contra

303 "esse tal tirano de que falas": É este passo que me leva a aceitar, no $\$ 23$, a lição "um certo tirano". 
os desgraçados dos cidadáos, violando virgens, corrompendo muitos adolescentes e comportando-se como um ébrio com os seus súbditos. Tu [Radamanto,] não serás capaz de fazê-lo pagar proporcionalmente à sua sobranceria, à sua vaidade e à sua altivez para com todos quantos tinham contacto com ele; seria mais fácil olhar fixamente para sol, do que para este tipo. E não só, mas, além disso, quem seria capaz de enumerar a crueldade das puniçóes inventadas por este fulano, que nem os seus familiares mais próximos poupava? Mas para que não se pense que isto [que eu digo] é uma calúnia sem fundamento, depressa o saberás, chamando cá os que foram assassinados por ele... mas, melhor ainda, estes, como estás vendo, vêm sem serem chamados, rodeiam-no e tentam estrangulá-lo. Todos estes, ó Radamanto, morreram às mãos do meliante, uns vitimados por terem mulheres formosas, outros por se indignarem com o facto de ele lhes raptar os filhos para fins desonrosos, outros porque eram ricos, outros porque eram honestos e virtuosos e não estavam nada satisfeitos com os seus actos.

27. RADAMANTO - Então, meu patife, que dizes a isto? MEGAPENTES - Quanto aos assassinatos que ele menciona, de facto, cometi-os, mas, quanto ao resto - adultérios, ultrajes feitos aos adolescentes e violaçóes de virgens —, tudo isso são mentiras de Cinisco contra mim.

CINISCO — Pois então, ó Radamanto, vou apresentar testemunhas do que afirmei.

RADAMANTO - A que testemunhas te referes?

CINISCO - Convoca lá, ó Hermes, a sua Candeia e a sua Cama, pois estes [objectos], por estarem lá presentes, conheciam bem o que ele fazia.

HERMES - Apresentem-se a Cama ${ }^{304}$ e a Candeia de Megapentes. Muito bem, fizeram muito bem em obedecer! ${ }^{305}$

RADAMANTO - Ora então digam-nos cá o que sabem a respeito aqui de Megapentes... Tu, Cama, fala em primeiro lugar.

304 "a Cama e a Candeia": Como autênticas personagens e testemunhas, os editores dão-lhes o direito à maiúscula...

${ }^{305} \mathrm{O}$ próprio Hermes fica um tanto admirado com o facto de a Cama e a Candeia se comportarem como pessoas. 
CAMA - As acusações de Cinisco são todas verdadeiras. Em boa verdade, ó meu Senhor Radamanto, até me envergonho de mencioná-las, tais eram os actos praticados em cima de mim.

RADAMANTO - O teu testemunho de acusação é muitíssimo claro, apesar de te acanhares na sua explicitação... Agora tu, Candeia, presta o teu testemunho.

CANDEIA - O que ele fazia durante o dia, eu cá nunca vi, pois não estava presente. Mas o que ele fazia e deixava fazer ${ }^{306}$ noite após noite, hesito em dizer... Em todo o caso, assisti a muitos actos inenarráveis, que ultrapassavam todos os ultrajes. Mesmo assim, muitas vezes fazia de propósito por náo beber o azeite, no intuito de me apagar, mas ele chegava-me para mais perto desses actos ${ }^{307}$ [abomináveis] e conspurcava de todas as maneiras ${ }^{308}$ a minha luz.

28. RADAMANTO - Bem, já basta de testemunhas. Agora despe essa veste de púrpura, para nós observarmos o número de estigmas... Tchiii! O tipo está todo lívido, todo marcado, ou melhor, está todo roxo devido aos estigmas. De que maneira deve ser punido? Lançamo-lo ao Piriflegetonte ${ }^{309}$ ou entregamo-lo a Cérbero?

CINISCO - De maneira nenhuma, mas antes, se estiveres de acordo, sugerir-te-ei uma punição original e adequada a este fulano.

RADAMANTO - Ora diz lá, que eu ficar-te-ei imensamente grato por isso.

CINISCO - É costume, julgo eu, que todos os mortos bebam água do Lete...

RADAMANTO - Sim, claro.

CINISCO - Portanto, que este fulano seja o único a não beber [dessa água].

306 "fazia e deixava fazer", alusão à homossexualidade activa e passiva.

307 "chegava-me para mais perto desses actos": Entende-se que a candeia ainda não estava completamente apagada, mas que, antes disso, emitia uma luz cada vez mais fraca, pelo que era preciso aproximá-la da cama.

308 "conspurcava de todas as maneiras": Há aqui uma alusão mais ou menos velada às diversas formas de conspurcação da luz da candeia, pelo facto de estar tão próxima do cenário da acção...

${ }^{309}$ Piriflegetonte era um dos rios do reino de Hades, um rio de fogo. Cérbero é o feroz cão do reino dos mortos, que morde em quem entra e não deixa sair ninguém... com notáveis excepções. Naturalmente, se o tribunal mandar entregar-lhe um condenado, Cérbero náo se faz rogado... 
29. RADAMANTO - Mas porquê?

CINISCO - Porque sofrerá um castigo bem penoso, sempre recordado de quem era, de quanto poder tinha lá em cima e passando em revista todo esse fausto.

RADAMANTO - Dizes bem. Que seja condenado nesses termos. Levem-no para junto de Tântalo e ponham-no a ferros, e que esteja sempre lembrado dos actos que praticou durante toda a vida. 
CARONTE OU OS VISITANTES 
(Página deixada propositadamente em branco) 


\section{INTRODUÇÁo}

Desta vez - caso insólito - é Caronte, o barqueiro do reino de Hades, que deixa a sua barca e sobe até à terra dos vivos. Motivo explicado a Hermes (\$1): "É que me deu o desejo, ó Hermes, de ver como são as coisas aí na vida, que é que os homens fazem nela, ou de que coisas se sentem privados, que fazem com que todos se lamuriem ao descer até nós. Realmente, nenhum deles $^{310}$ alguma vez fez a travessia sem chorar."

Apesar de muito ocupado com tarefas ordenadas por Zeus, Hermes acede a ser o guia "turístico" do seu "colega" Caronte. Inspirando-se num passo homérico, em que os filhos de Aloeu, os gigantes Oto e Efialtes, a fim de escalarem o céu, empilharam os montes Ossa, Olimpo e Pélion, Caronte e Hermes transportam o monte Ossa para cima do Pélion, a que acrescentam o Eta e o Parnaso, ficando assim numa posiçáo privilegiada para observarem praticamente toda a terra. Caronte, porém, não se contenta por observar as cidades e a restante paisagem, mesmo assim em tamanho muito reduzido. O que ele pretende, acima de tudo, é observar os homens, como se estivesse muito perto deles... problema que Hermes resolve com toda a facilidade, com uma simples citação (mágica) tirada de Homero (\$7). Surpreendentemente para Hermes, Caronte mostra-se profundo conhecedor da poesia homérica, o que explica pelo facto de Homero, ao fazer a viagem derradeira, a viagem para o Hades, ter recitado muitas das suas rapsódias, nomeadamente quando, durante uma violentíssima tempestade, enjoou, do que resultou ter vomitado uma grande quantidade de matéria poética (!).

Do seu posto de observaçáo vêem, por exemplo, o atleta Míron de Crotona, Ciro, filho de Cambises, Creso, opulento rei de Sárdis, em conversa com o ateniense Sólon, Polícrates, tirano de Samos, os quais, no meio de tanto fausto e de tanta "felicidade", não se apercebem de que terão um fim trágico.

Também não faltam, personificados diversos conceitos e vícios: as Esperanças, os Temores, as Ignorâncias, as Volúpias, as Cobiças, as Iras, os Ódios, enfim, todo um cortejo de fraquezas humanas.

Entấo o rude Caronte, compreendendo o lado ao mesmo tempo trágico e vazio da condiçáo humana, sai-se com uma

310 “nenhum deles”... com excepção dos filósofos cínicos (Diógenes, Menipo, Cinisco...) e alguns pobres que não tinham nada por que chorar... 
comparação digna de Homero (\$19): a vida dos homens é comparável a bolhas de água, umas maiores, outras mais pequenas, mas que, todas elas, acabam por se desfazer em nada.

E no \$20: “Ó vâs criaturas, porque é que vos ocupais de tais coisas? Cessai de vos afadigar, pois não vivereis para sempre. Não é eterna nenhuma de entre as coisas que aqui [na terra] são veneráveis, e ninguém, depois de morto, levará consigo nenhuma delas, mas, pelo contrário, é forçoso que parta completamente nu, $e$ que a sua casa, o seu campo, o seu ouro pertençam sucessivamente a outros e passem para outros donos."

No $\$ 22$, Caronte continua a surpreender Hermes, ao aglomerar diversos passos de Homero num conjunto de notável força poética:

Igual na morte é o homem, | tenha ou não tenha jazigo; A mesma honra tem Iro ${ }^{311}$ | que tem o nobre Agamémnon; Igual ao feio Tersites ${ }^{312} \mid$ é o filho da bela Tétis.

Todos não passam de crânios | inconsistentes de mortos, todos nus e descarnados, I por esse prado de asfódelo ${ }^{313}$.

Até ao fim, desenrola-se perante nós o trágico fim de prósperas cidades, como Nínive de Sardanapalo, Babilónia, Micenas, Cleonas, a famosa Tróia...

${ }^{311}$ Iro (ou Arneu) é um mendigo insolente de Ítaca, a quem Ulisses aplicou um correctivo (Odisseia, XVIII, 5...).

312 Tersites era o mais feio de entre os gregos que tomaram parte na guerra de Tróia; o filho de Tétis é Aquiles. Note-se que o texto não diz "bela Tétis", mas "Tétis de bela cabeleira" — necessidade métrica do tradutor.

$313 \mathrm{O}$ asfódelo é uma "planta liliácea, de raiz tuberosa e belas flores ornamentais" ("Lello"). Julgo tratar-se de uma espécie de lírio ("Olhai os lírios do campo..."). Trata-se de uma ornamentação paradisíaca da zona dos bem-aventurados... 


\section{Caronte ou Os Visitantes}

1. HERMES - Porque te ris, ó Caronte? E porque é que deixaste a tua barca para subir até cá à nossa terra, tu que não estás habituado a contactar com as coisas cá de cima?

CARONTE - É que me deu o desejo, ó Hermes, de ver como são as coisas aí na vida, que é que os homens fazem nela, ou de que coisas se sentem privados, que fazem com que todos se lamuriem ao descer até nós. Realmente, nenhum deles ${ }^{314}$ alguma vez fez a travessia sem chorar. Ora, tendo eu, à semelhança do célebre jovem tessálico ${ }^{315}$, solicitado a Hades que me concedesse um só dia de falta, subi aqui à luz, e parece-me que tive a sorte de te encontrar, pois tenho a certeza de que me servirás de guia, acompanhando-me por aí e mostrando-me cada coisa, como pessoa que as conhece a todas.

HERMES - Ó barqueiro, não tenho vagar, pois neste momento vou daqui a fim de cumprir junto dos humanos uma missão que me foi confiada por Zeus... aquele lá de cima ${ }^{316}$. E olha que ele tem mau feitio, pelo que receio que, se eu me atrasar, ele faça com que eu seja todo vosso, lançando-me às trevas, ou então, como fez outrora a Hefesto, me pegue por um pé e me atire da divina morada, de modo que também eu, escanção $\operatorname{coxo}^{317}$, seja motivo de risota [dos deuses].

314 "nenhum deles"... com excepção dos filósofos cínicos (Diógenes, Menipo, Cinisco...) e alguns pobres que náo tinham nada por que chorar (o sapateiro Micilo...).

${ }^{315}$ Referência a Protesilau, herói tessálico, que, mal acabado de desposar Laodamia, embarcou na expedição a Tróia; assim que pôs o pé em terra, foi morto por uma flecha lançada por Heitor. Tendo suplicado a Hades (Plutão) que lhe permitisse ir à terra por pouco tempo, foi-lhe concedida essa excepção. Passado o tempo fixado, teve de regressar ao Hades, mas juntamente com Laodamia, que se suicidara...

316 Hermes - imagino eu — deve fazer acompanhar esta referência ("aquele lá de cima”) de um gesto com o dedo indicador apontado ao céu, a fim de fazer sentir a Caronte que primeiro estava o grande Zeus...

317 "escanção coxo", ou melhor, sujeito a tornar-se coxo. O escanção "efectivo" de Zeus era o jovem, e humano, Ganimedes, mas, pelos vistos, Hermes, em caso de necessidade, também "servia à mesa". O caso de $\mathrm{He}$ festo (o Vulcano romano), aqui referido, náo chega a concretizar-se com Hermes... Durante uma discussão entre seu Pai, Zeus, e sua mãe, Hera, Hefesto tomou o partido da Máe, o que enfureceu o Pai, que o lanço do Olimpo abaixo, num voo que durou um dia inteiro, indo cair na ilha de 
CARONTE - Quer dizer que te será indiferente veres-me vagueando ao acaso pelo mundo, mesmo sendo eu teu companheiro, camarada de navegação e contigo passador de almas? No entanto, ó filho de Maia, seria bom que te lembrasses de que nunca te mandei escoar a água ou pegar no remo. Pelo contrário, não fazes senão ressonar, estendido na coberta, apesar de teres uns ombros tão robustos, ou então, se dás com algum morto tagarela, ficas a discutir com ele durante toda a viagem, enquanto eu, que sou velho, manobro sozinho um par de remos... Então, pelo teu Pai!, ó Hermesinho, não me abandones, mas sê meu guia em tudo que há [para ver] na vida, para que, depois de ver alguma coisa, eu possa regressar. Se me abandonares, não serei em nada diferente dos cegos, pois, assim como estes tropeçam e cambaleiam nas trevas, assim também eu fico encandeado pela luz frontal. Mas, ó Cilénio ${ }^{318}$, faz-me esse favor, do qual me lembrarei para sempre.

2. HERMES - Este assunto ainda vai ser causa de eu levar pancada. Estou mesmo a ver que a paga por este meu trabalho de guia não me vai ser mesmo nada isenta de murros. Em todo o caso, há que prestar este serviço. Sim, que remédio tenho eu, quando um amigo a isso me obriga?

De toda a maneira, ó barqueiro, é completamente impossível ver tudo minuciosamente, pois isso levaria muitos anos, e então Zeus mandar-me-ia apregoar como se eu fosse um escravo fugitivo, e a ti impedir-te-ia de executar a tarefa de Tânato ${ }^{319}$, enquanto o reino de Plutão teria um grande prejuízo, pelo facto de tu estares tanto tempo sem transportar mortos; além disso, o portageiro Éaco ficaria furioso por não receber nem um óbolo. Assim sendo, compenetra-te de que só poderás ver as coisas principais.

CARONTE - Faz o que for melhor, Hermes; eu não sei nada das coisas da terra, pois sou estrangeiro.

HERMES - Antes de mais, ó Caronte, precisamos de um sítio elevado, de onde possas observar tudo. Se te fosse possível subir até ao céu, não teríamos qualquer dificuldade, pois verias

Lemnos. Os deuses gostavam muito de rir do defeito de Hefesto - tudo coisas muito educativas...

318 "Cilénio", um dos epítetos de Hermes, que nasceu no monte Cilene, na Arcádia.

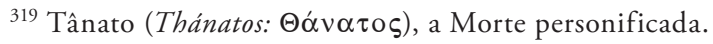


tudo perfeitamente desse posto de observação. Como, porém, uma vez que convives com as sombras, não te é permitido ascender à morada real de Zeus, há que procurar por aí uma alta montanha.

3. CARONTE - Sabes, ó Hermes, o que eu costumo dizer-vos quando navegamos? Quando o vento, soprando forte, bate obliquamente na vela e se levanta uma ondulação muito alta, e vós, na vossa ignorância, me sugeris que amaine a vela, ou que afrouxe um pouco o cabo da bolina, ou que deixe ir [a barca] ao sabor do vento, eu convido-vos a que fiqueis caladinhos, pois eu é que sei o que é melhor. Neste caso, procede como julgares que está bem, pois agora és tu o... piloto. Quanto a mim, como é de norma entre os passageiros, ficarei sentado em silêncio, obediente a tudo quanto me mandares fazer.

HERMES - Dizes bem. Sim, eu saberei o que fazer e hei-de achar um posto de observação satisfatório. Não será o Cáucaso adequado, ou o Parnaso, ou o famoso Olimpo, que é mais alto que aqueles dois? Ora, ao considerar o Olimpo, ocorreu-me uma ideia que não me parece nada má... mas tu tens de fazer força juntamente comigo e ajudar-me.

CARONTE - Dá as tuas ordens, que eu farei tudo o que puder.

HERMES - Diz o poeta Homero que os filhos de Aloeu ${ }^{320}$, que também ${ }^{321}$ eram só dois, propuseram-se uma vez, sendo ainda rapazes, arrancar o monte Ossa da sua base e colocá-lo em cima do Olimpo, pondo a seguir o Pélion em cima do monte Ossa, cuidando que obteriam assim uma escada adequada para subirem até ao céu. Esses dois jovens, na verdade bem loucos, foram punidos. Nós dois, porém, que não empreendemos esta acção para mal dos deuses, porque é que não havemos também nós de operar da mesma maneira, fazendo rolar as montanhas umas sobre as outras, a fim de obtermos, lá do alto, um observatório mais perfeito?

4. CARONTE - Mas, ó Hermes, seremos nós capazes, sendo apenas dois, de elevar e colocar o Pélion ou o monte Ossa?

${ }^{320}$ Os filhos de Aloeu são os gigantes Oto e Efialtes, cuja história se resume a seguir.

321 "também", ou seja, "tal como nós". 
HERMES — E porque não, ó Caronte? Ou cuidas tu que nós somos mais fracos que aqueles dois bebezinhos ${ }^{322}$, tanto mais que somos deuses?

CARONTE - Não, mas a empresa afigura-se-me envolver uma enorme e incrível trabalheira.

HERMES - Está visto, ó Caronte: és um ignorante e mesmo nada dado à poesia. O bom do Homero, somente em dois versos, tornou-nos logo o céu escalável, ao juntar facilmente aquelas montanhas. E até me espanta que isso te pareça prodigioso, quando conheces muito bem o caso de Atlas, que, sendo só um, suporta o próprio Universos e carrega com todos nós. Talvez até tenhas ouvido falar do meu irmão Héracles, de como este, uma vez, tomou o lugar de Atlas e o aliviou por algum tempo dessa carga, tomando-a nos ombros.

CARONTE - Sim, já ouvi falar dessas coisas. Se elas são verdadeiras, tu, ó Hermes, bem como os poetas... vós lá o sabereis...

HERMES - Verdadeiríssimas, ó Caronte. Sim, por que motivo é que esses homens tão sábios haviam de mentir? ${ }^{323}$ Portanto, alavanquemos ${ }^{324}$ primeiro o monte Ossa, como nos mandam fazer o verso e o arquitecto Homero ${ }^{325}$ :

\section{e sobre a Ossa,}

o Pélion de fremente folhagem.........

Estás a ver quão fácil e, ao mesmo tempo "poeticamente"326 trabalhámos? Ora então vou lá acima ver se já basta assim, ou se vai ser preciso executar mais obra...

322 "bebezinhos" é tradução estritamente literal; brephüllion ( $\beta \rho \varepsilon \varphi v ́ \lambda \lambda \iota \mathrm{rov})$ é um diminutivo (até "reforçado") de bréphos ( $\beta \rho \varepsilon ́ \varphi$ s)), "bebé”. É óbvia a ironia e o desprezo da designação.

${ }^{323}$ Nitidamente, Luciano estaria a rebolar-se de riso: É claro, claríssimo, que os poetas nunca mentem!

324 "alavancar", apesar de ser palavra "moderníssima”, deu-me aqui um grande jeito, pois a tradução é mesmo literal: anamokhleúo ( $\alpha \vee \alpha \mu \mathrm{\chi} \chi \lambda \varepsilon v ́ \omega)$, de ana- "movimento para cima" + mokhleúo ( $\mu$ o $\chi \lambda \varepsilon v ́ \omega)$ "usar a alavanca",

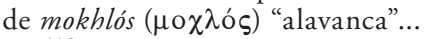

325 Odisseia, XI, 315-316.

326 "poeticamente": $\mathrm{O}$ advérbio tem aqui muita piada, pois, no contexto, significa "por sugestão do poeta Homero"... 
5.... Tchiii! Ainda estamos cá em baixo, no sopé do céu! De facto, as bandas do Oriente, mal se vislumbra a Jónia e a Lídia, das bandas do Ocidente não mais que a Itália e a Sicília, das bandas da Ursa somente as terras do Ístro ${ }^{327}$, e deste sítio aqui, só Creta, e não muito nitidamente. Portanto, ó barqueiro, há que transportar para aqui também o $\mathrm{Eta}^{328} \mathrm{e}$, por cima destes todos, segundo parece, o Parnaso.

CARONTE - Façamos assim. Mas vê lá não façamos uma obra muito fraca, ao alongá-la para lá do razoável; depois tendo-nos despenhado juntamente com a construção, ficaríamos com uma experiência da arquitectura homérica, ao quebrarmos as nossas cabeças.

HERMES - Fica tranquilo, que tudo se fará com segurança. Muda para aqui o monte Eta; agora, que seja rolado o Parnaso. Ora bem, vou de novo lá acima... Está bem assim, já vejo tudo. Ora sobe também tu.

CARONTE - Ó Hermes, estende-me a mão. Realmente, não é uma pequena obra de engenharia que tu me fazes subir.

HERMES - E é se queres ver tudo, ó Caronte... Não é possível teres ambas as coisas [ao mesmo tempo]: segurança e desejo de boa visibilidade. Mas agarra-te à minha mão direita e evita pôr o pé em sítios escorregadios. Muito bem! Já estás cá em cima. E já que o Parnaso tem dois cumes, sentemo-nos, cada um de nós ocupando um pico. Olha em toda a tua volta e observa todo o mundo.

6. CARONTE - Estou vendo uma enorme extensão de terra, um lago muito grande a rodeá-la, montanhas e rios, maiores que o Cocito e o Piriflegetonte, e ainda homens muito pequenos e os seus covis.

HERMES - O que tu cuidas serem tocas são as cidades.

CARONTE - Será que te apercebes, ó Hermes, de que não fizemos nada [que valesse a pena], pois foi em vão que transportámos para aqui o Parnaso mais a sua fonte Castália, o monte Eta e as outras montanhas?

HERMES - E porquê?

CARONTE - É que, desta tão grande altura, não vejo nada que esteja bem nítido. $\mathrm{O}$ que eu precisava de ver não são cidades e montanhas como nas pinturas, mas sim os próprios

327 "Istro", nome antigo do Danúbio.

328 "Eta” [-è-], monte da Tessália. 
homens, o que eles fazem e o que eles dizem, como, logo de início ${ }^{329}$, me encontraste e deste comigo a rir e me perguntaste porque é que eu estava rindo... Foi o caso que me deu um gozo enorme ao ouvir certa coisa...

HERMES - E que coisa foi essa?

CARONTE - Certo indivíduo, tendo sido convidado por outro - julgo que para o jantar do dia seguinte —, disse: "Com toda a certeza, lá estarei." Ora, enquanto ele falava, uma telha, que caíra do telhado, movida náo sei por quem, atingiu- $\mathrm{o}^{330} \mathrm{e}$ matou-o. Então eu fartei-me de rir, pelo facto de ele não poder cumprir a promessa.... Bem, parece que tenho de descer mais abaixo, para poder ver e ouvir melhor.

7. HERMES - Fica aí quietinho, que eu vou curar-te disso num instante: Pegando numa fórmula mágica de Homero adequada a este caso, vou tornar-te extremamente penetrante de vista; assim que eu recitar esses versos, pensa que năo estás fraco de vista, mas sim que vês tudo com nitidez.

CARONTE - Diz lá então.

HERMES -

E de teus olhos tirei $\mid$ a névoa que os envolvia, pra que fiques conhecendo |quem é deus e quem é homem. ${ }^{331}$

... Então, agora já vês?

CARONTE - Maravilhosamente! O famoso Linceu ${ }^{332}$, comparado comigo, era cego. Pois agora faz de meu mestre e responde às minhas perguntas... Mas queres que também eu te faça perguntas tiradas de Homero, para que fiques sabendo que eu não sou alheio à poesia homérica?

HERMES - E como é que podes conhecer a sua poesia, tu, que sempre foste um marinheiro e um remador?

329 "no início", precisamente no $\$ 1$.

330 A ideia de "cair" e "atingir" está contida na forma empesoûsa $(\varepsilon \mu-\pi \varepsilon \sigma o \hat{v} \sigma \alpha)$, “cair em cima de". Poderíamos traduzir por "tendo-lhe caído em cima, ... matou-o”.

${ }^{331}$ Ilíada, V, 127-128. Atena faz com que Diomedes possa distinguir, na refrega, quem é deus e quem é humano, para que não lute contra os imortais... De facto, por muitas vezes os deuses apareciam disfarçados...

332 Linceu era um dos Argonautas, famoso pela sua visão penetrante. Nós dizemos ter olhos de lince... 
CARONTE - Bem vês, essa pergunta é ofensiva do meu talento. Ora eu, enquanto passava esse poeta, quando ele morreu, ouvi-o recitar muitas rapsódias, e ainda me lembro de algumas. Foi então que uma tempestade nada pequena nos caiu em cima. O poeta tinha começado a cantar um episódio que não era de bom augúrio para os navegantes, por exemplo, como Posídon juntou as nuvens e agitou o mar, enfiando nele o tridente como se fosse um colherão de sopa, assim desencadeando todas as tempestades... E [recitava] muitos outros episódios, revoltando o mar com os seus versos, pelo que, de súbito, caiu sobre nós um [enorme] temporal e uma [grande] escuridão, pouco faltando para nos virar o barco. Então ele enjoou, tendo vomitado muitas das suas rapsódias, entre as quais a de Cila e Caríbdis e a do Ciclope. Não é, portanto, difícil reter alguma coisa de tão grande vomitadela ${ }^{333} \ldots$ Mas agora diz-me cá

Que tipo é este, tão forte, | tão elegante e tão alto, que sobressai entre os homens | por seu busto e largos ombros?334

HERMES - Este é o atleta Mílon de Crotona. Os Gregos estão neste momento a aplaudi-lo, pelo facto de ele ter levantado o touro e ter carregado com ele ao longo do estádio.

CARONTE - Ó Hermes, com que mais justo motivo eles me aplaudirão, pelo facto de eu, em breve, pegar nele e o enfiar no barquinho, quando ele vier até nós, derrotado pelo mais invencível dos adversários - a Morte, que, sem ele disso se aperceber, lhe passará uma rasteira. Depois, virá queixar-se a nós, recordando-se dessas coroas e dos aplausos. Neste [preciso] momento, está muito orgulhoso com o facto de ser muito admirado por ter carregado com o touro. E então? Pensamos nós porventura que ele encara a expectativa de morrer um dia?

HERMES - Como poderia ele lembrar-se da morte, agora que está na força da juventude?

CARONTE - Mas deixa lá, que dentro de não muito tempo ele proporcionar-nos-á motivo de risota, quando já estiver embarcado e incapaz de levantar, não já um touro, mas nem mesmo um mosquito... Mas agora diz-me cá:

${ }^{333}$ Alguns editores atribuem esta última frase a Hermes...

${ }^{334}$ Adaptação de Homero, Iliada, III, 326-327. Na Ilíada, faz-se referência a Ájax e à sua qualidade de "Aqueu"... 
Não é grego, pelo menos a julgar pelas vestes...

HERMES - Ó Caronte, é Ciro, filho de Cambises, que fez com que o Império que outrora pertencia ao Medos passasse agora para os Persas. Este rei venceu os Assírios e apoderou-se de Babilónia, e agora parece querer marchar contra a Lídia, a fim de derrubar Creso e tornar-se dono do mundo.

CARONTE - Mas... onde raio está o famoso Creso?

HERMES - Olha para aquele lado, para aquela grande acrópole com uma tripla muralha. É a famosa Sárdis ${ }^{336}$, e vês também o próprio Creso reclinado num leito de ouro, a conversar com o ateniense Sólon. Queres escutar o que eles estão a dizer?

CARONTE - Sim, quero muito.

10. $\mathrm{CRESO}^{337}$ - Meu hóspede ateniense, tu viste a minha riqueza, os meus tesouros, todo o meu ouro em barra e toda a minha magnificência. Diz-me, pois, qual de entre todos os homens consideras o mais feliz.

CARONTE — Que é que Sólon irá dizer?

HERMES - Tem calma, Caronte; [certamente] nada de ordinário.

SÓLON - Ó Creso, são muito poucos os individuos felizes. Pelo que me diz respeito, de entre os que eu conheço, considero como sendo os mais felizes Cléobis e Biton, filhos da sacerdotisa de Argos, que 338 morreram ambos recentemente, quando se atrelaram ao carro e levaram a mãe até ao templo $0^{339}$.

CRESO - Seja. Que esses dois tenham o primeiro lugar da felicidade. E então quem será o segundo?

${ }_{335}$ Mais uma adaptação de Homero, Ilíada, III, 326-327 (v. nota supra).

336 Sárdis é a forma correcta em português, adaptada regularmente do gr. Sárdeis / Sárdis ( $\Sigma \alpha ́ \rho \delta \varepsilon \imath \varsigma / \Sigma \alpha ́ \rho \delta \imath \varsigma)$, fem. pl.; Mesmo a forma com -ei-teria a mesma adaptação; de resto, a forma latina é precisamente Sardīs, correspondendo à pronúncia gr. [-ei-] > [-i-], cf. gr. Alexándreia, lat. Alexandría... ; a forma Sardes é (como outras, indevidamente) tirada do francês. É certo que o uso (mesmo resultante de ignorância) faz lei...

337 Luciano inspira-se em Heródoto, I, 29-33. Escrevo em itálico o diálogo dentro do diálogo.

${ }^{338}$ Há quem atribua esta segunda parte a um comentário explicativo feito por Caronte. Parece-me mais aceitável continuar a atribuir a fala a Sólon.

${ }^{339}$ Os jovens morreram devido ao esforço que tiveram de fazer. É um caso famoso de amor filial. 
SÓLON - O ateniense Telo, que viveu com muita dignidade e morreu pela Pátria.

CRESO - Ó meu malandro, então eu não te pareço feliz?

SÓLON - Ainda não sei, ó Creso, uma vez que não chegaste ao fim da tua vida. Realmente, a morte é que faz um juizo seguro nessa matéria, [a saber,] se a pessoa viveu feliz até ao termo.

CARONTE - Muitíssimo bem, ó Sólon, por não te teres esquecido de nós, ao considerares que o julgamento de tais questóes é feito depois desta barca ${ }^{340} \ldots$

11. ... Mas... quem são aqueles homens que Creso está a enviar? E que é que eles levam às costas?

HERMES - São lingotes de ouro que ele oferece ao [Apolo] Pítio $^{341}$, como paga dos oráculos pelos quais, daqui a muito pouco tempo, ele vai perecer. O homem está mesmo viciado em profecias.

CARONTE - É o quê? Aquilo é que é o ouro, aquela coisa brilhante e a lampejar, aquela coisa entre o amarelado e o vermelho? Sim, é esta a primeira vez que o vejo, embora sempre tenha ouvido falar dele.

HERMES - Sim, ó Caronte, é este o seu decantado nome, objecto de muitas desavenças.

CARONTE - Mesmo assim, não estou a ver que é que ele tem de bom, a não ser, talvez, apenas o facto de os carregadores ficarem vergado ao seu peso.

HERMES - Então não sabes quantas guerras, quantas intrigas, quantos roubos, quantos perjúrios, quantos assassinatos, quantos aprisionamentos, quanto comércio marítimo e quantas escravidões se fazem por causa deste [metal]?

CARONTE - Por causa deste, ó Hermes, que não é muito diferente do cobre? ${ }^{342} \mathrm{Sim}$, que o cobre conheço-o eu, pois, como sabes, cobro um óbolo por cada pessoa que eu passo lá para baixo.

340 "Depois desta barca" ou "depois desta viagem”, e não "durante...", como alguns interpretam. Trata-se de um dos sentidos da prep. pará $(\pi \alpha \rho \alpha)$ com acusativo.

${ }^{341}$ Apolo Pítio, em Delfos, local do mais famoso oráculo da Antiguidade.

342 "cobre": a palavra khalkós ( $\chi \alpha \lambda \kappa$ אó $\varsigma$ ) também pode significar "bronze", mas neste contexto é preferível interpretar por "cobre", por se fazer referência, logo a seguir, aos óbolos de cobre. 
HERMES - Pois sim, mas o cobre existe em abundância, pelo que não é lá muito procurado pelas pessoas; enquanto o ouro, que é pouco, os mineiros vão desenterrá-lo a grandes profundidades, este [o cobre], tal como o chumbo e outros metais, é tirado da [superfície da] terra ${ }^{343}$.

CARONTE - Estás a falar de uma terrível estupidez dos homens, que amam com tal paixão uma coisa amarelada e tão pesada.

HERMES - Mas, ó Caronte, o famoso Sólon não parece estimar muito o ouro, pois, como vês, troça de Creso e da sua jactância de bárbaro... Mas... parece que ele vai perguntar uma coisa... Escutemo-lo.

12. SÓLON - Diz-me cá, ó Creso, achas que o [Apolo] Pítio tem alguma necessidade desses lingotes [de ouro]?

CRESO - Tem, sim, por Zeus! Na verdade, ele não possui em Delfos nenhuma oferenda como esta.

SÓLON - Achas então que fazes com esse deus fique feliz, se acrescentar às outras oferendas os lingotes de ouro?

CRESO - E porque não?

SÓLON - Pelo que me dizes, ó Creso, reina uma enorme penúria no céu, se [é verdade] que os deuses necessitam de que thes enviem da Lidia o ouro que eles tanto desejam...

CRESO - E onde é que haverá tanto ouro como neste meu pais?

SÓLON - Diz-me cá: Existe ferro na Lidia?

CRESO - Não muito.

SÓLON - Portanto, careceis do melhor [metal].

CRESO - E porque é que o ferro é melhor que o ouro?

SÓLON - Se me responderes sem te zangares, ficarás a sabê-lo.

CRESO - Então pergunta lá, ó Sólon.

SÓLON - Quais destes [homens] são melhores: os que salvam outros [homens], ou os que sáo salvos por esses outros?

CRESO - Os que salvam outros, claro.

SÓLON - Portanto, se Ciro, como para ai se diz, atacar os Lidios, será que tu mandarás distribuir pelo teu exército espadas de ouro, ou o ferro é que, nessas circunstâncias, será necessário?

CRESO - O ferro, é claro.

SÓLON - E se tu não conseguires abastecer-te deste metal, o teu ouro passará, como presa de guerra, para os Persas.

343 Refere-se sobretudo às exploraçóes a céu aberto... 
CRESO - Ó homem, longe vá o agoiro!

SÓLON — Oxalá tal não aconteça... Portanto, pareces admitir que o ferro é mais valioso que o ouro.

CRESO - Quererá isso dizer que me aconselhas a oferecer ao deus lingotes de ferro, e de receber de volta o [meu] ouro?

SÓLON - Esse deus também náo necessitará do teu ferro, porquanto, quer the ofereças cobre, quer lhe ofereças ouro, a tua oferenda será um dia pertença e presa de outros: dos Fócios, ou dos Beócios, ou dos próprios Délfios, ou de algum tirano, ou de um assaltante... O deus, porém, pouco se importará com os teus ourives.

CRESO - Estás sempre a atacar e a dizer mal da minha riqueza.

13. HERMES - Ó Caronte, o Lídio não suporta a franqueza e a verdade das palavras, mas, pelo contrário, parece-lhe absurdo o facto de um homem pobre não se humildar, mas dizer livremente o que lhe vem à cabeça... Mas passado algum tempo há-de lembrar-se de Sólon, quando for aprisionado e lançado na fogueira por Ciro. Na verdade, ouvi, ainda recentemente, Cloto ler o destino fiado para cada pessoa, onde este caso estava escrito, [e se dizia que] Creso seria capturado por Ciro, e que o próprio Ciro seria morto ali por aquela mulher massagétide ${ }^{34} \ldots$... Estás vendo aquela mulher da Cítia, a montada naquele cavalo branco?

CARONTE - Pois essa é Tómiris, que cortará a cabeça de Ciro e a enfiará num odre cheio de sangue... Estás vendo também o seu filho, ainda muito jovem? Pois esse é Cambises, que reinará a seguir a seu pai e que, depois de sofrer mil desastres na Lídia e na Etiópia, acabará por enlouquecer e matar o boi Ápis.

CARONTE - Que coisa tão divertida! Mas agora, quem ousaria olhá-los de frente, esses tipos táo altivos com as outras pessoas? E quem acreditaria que, dentro de pouco tempo, um será feito prisioneiro, e o outro terá a cabeça metida num odre [cheio] de sangue?...

344 “mulher massagétide”, i. é, do povo chamado Masságetas, na Cítia (Ásia Menor); na verdade era a sua rainha, Tómiris, cujo exército derrotou e dizimou o exército persa. Ciro, na verdade, morreu em combate; a rainha somente decapitou o seu inimigo... Enfim, são pormenores. Pode ler, p. ex., Heródoto, I, 211-215... 
14. ... Mas... quem é aquele tipo, ó Hermes, todo acolchetado $^{345}$ num manto de púrpura, com um diadema, a quem o cozinheiro está a dar um anel [que achou] ao abrir um peixe ${ }^{346}$,

\section{numa ilha de ondas cercada? | Dir-se-ia que é um reij37.}

HERMES - Mas que excelente paródia, ó Caronte. Pois estás vendo Polícrates, tirano de Samos, que se considera um homem totalmente feliz. No entanto, traído e entregue ao sátrapa Orete pelo seu criado Meândrio, que está a seu lado, será crucificado, o infeliz, caindo, num breve instante, do alto da sua felicidade. Este facto, também o ouvi da boca de Cloto.

CARONTE - Como eu admiro esta nobre Cloto! Queima-os, cara amiga, corta-lhes as cabeças, crucifica-os, para que eles saibam que são homens. Que eles sejam elevados até aos píncaros, pois de quanto mais alto caírem, mais dolorosa será a queda. Então eu fartar-me-ei de rir, ao reconhecer cada um deles na minha barca, todos nus, sem trazerem consigo nem mantos de púrpura, nem tiaras, nem tronos de ouro.

15. HERMES - É esse o seu destino... Mas estás vendo, ó Caronte, aquela multidão, uns navegando, outros guerreando, outros envolvidos em processos judiciais, outros lavrando a terra, outros emprestando dinheiro a juros, outros mendigando?

CARONTE - Sim, vejo uma actividade muito variada e uma vida plena de perturbaçáo, as suas cidades semelhantes colmeias, nas quais cada um tem o seu próprio aguilhão e pica o vizinho, enquanto alguns, poucos, tal qual vespas, sugam e

345 "acolchetado": Os mantos eram presos no ombro por uma fivela ou colchete, a fim de segurar uma das pontas. O termo utilizado por Luciano tem o seu quê de troça, pelo seu tamanho e aliteraçóes: empeporpéménos

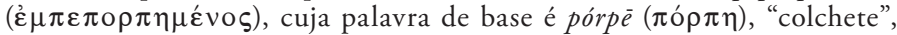
"fivela", "fíbula" (lat. fibǔla).

346 Trata-se da famosa história do anel de Polícrates, tirano de Samos, contada por Heródoto, III, 39-43. Como a felicidade excessiva suscitava a inveja e o castigo dos deuses, Polícrates decidiu martirizar-se, desfazendo-se de um preciosíssimo anel, que lançou ao mar. Depois... o anel foi engolido por um peixe, o qual, por sua vez, foi pescado por um pescador, que o ofereceu a Polícrates... O cozinheiro, ao preparar o peixe, achou nele o anel, que devolveu ao tirano. A tragédia vem depois, como se diz a seguir...

${ }^{347} \mathrm{O} 1^{\circ}$ hemistíquio é tirado da Odisseia, I, 50; o 20 é inspirado, com adaptação, no 2o hemistíquio da Odisseia, I, 180. 
roubam os mais fracos... Mas... quem é esta multidão de figuras discretas que esvoaçam à volta das pessoas?

HERMES - Ó Caronte, são as Esperanças ${ }^{348}$, os Temores, as Ignorâncias, as Volúpias, as Cobiças, as Iras, os Ódios e demais entidades desse género. De entre estas, a Ignorância está na base, misturada no íntimo das pessoas e com elas convivendo, assim como, por Zeus!, o Ódio, a Ira, a Inveja, a Imbecilidade, a Dúvida, a Cupidez, enquanto o Temor e as Esperanças esvoaçam na parte superior: aquele baixa algumas vezes sobre as pessoas e fá-las tremer, ao passo que as Esperanças voam à volta das suas cabeças, mas, quando uma pessoa cuida que está prestes a alcançá-las, partem voando, deixando-a de boca aberta, tal qual vês Tântalo, lá em baixo, a sofrer [de sede] com a água tão perto...

16. ... Se olhares bem, avistarás também as Moiras ${ }^{349}$ fiando para cada pessoa o seu destino, donde acontece que todos estão suspensos por finíssimos fios. Estás a ver assim uma espécie de fios de teia de aranha que vão dos fusos para cada pessoa?

CARONTE - Sim, vejo que cada pessoa está ligada a um fio muitíssimo fino, a maior parte das vezes entrelaçado com o [fio] desta ou daquela pessoa.

HERMES - É natural, ó barqueiro. Realmente, está destinado que tal pessoa seja assassinada por tal pessoa, e esta por outra, que tal indivíduo seja herdeiro de um outro cujo fio é mais curto, ou, pelo contrário, que este seja herdeiro daquele. É isso mesmo o que o entrelaçamento revela. Como vês, todos estão pendentes de um fiozinho. Aqui esta pessoa, puxada para cima, está nos píncaros [da fortuna], mas, passado pouco

348 “as Esperanças...”, etc. (tudo no plural): Creio que tanto pode significar "a Esperança que habita em cada um...", etc., ou seja, "as diversas esperanças...”, como a Esperança, os Temores, etc., personificados, como, de resto, se vê um pouco adiante, onde se diz "o Temor e a Esperança esvoaçantes”, em que o particípio está no masc. pl., petómenoi ( $\pi \varepsilon \tau$ ó $\mu \varepsilon v 01$ ), e não no neutro, se se tratasse de meros conceitos, caso em que teríamos o neutro pl. *petómena $(\pi \varepsilon \tau o ́ \mu \varepsilon v \alpha)$. Os editores hesitam entre maiúsculas e minúsculas...

${ }^{349}$ Repito as notas de $A$ Travessia para o Hades ou O Tirano. \$8: Moira (Mô̂ $\rho)$, na adaptação regular ao port. deve ser Mera, forma que, uma vez (ou algumas mais vezes) sem exemplo, transcrevo do grego, em vez de proceder à adaptação “canónica”... \$1: Eram três irmãs: Atropo, fem. (que fiava a vida humana), Cloto (que enrolava o fio) e Láquesis (que cortava o fio da vida humana). 
tempo, uma vez quebrado o fio, por já não aguentar o seu peso, cairá daí abaixo, fazendo um grande estrondo, enquanto aquela ali, só um poucochinho elevada acima do solo, mesmo que caia, cairá ${ }^{350}$ sem fazer estrondo, pelo que a sua queda muito dificilmente será ouvida pelos vizinhos.

CARONTE - Isso é muitíssimo engraçado, ó Hermes.

17. HERMES - Mesmo assim, ó Caronte, tu não serias capaz de exprimir devidamente como tudo isso é risível, especialmente as suas desmesuradas ambições e o facto de, no meio das suas expectativas, partirem, nossa excelentíssima amiga Morte. Esta possui, como vês, mensageiros e ministros em elevado número, [como por exemplo] arrepios, febres, fraquezas, peripneumonias, [e ainda] espadas, quadrilhas de ladróes, venenos ${ }^{351}$, juízes e tiranos. Ora, enquanto gozam de prosperidade, nenhum destes males lhes ocorre, mas, se caem em desgraça, são muitos os lamentos, os choros e os ais. Se eles, logo de início, se compenetrassem de que eram mortais e de que, após terem migrado por pouco tempo nesta vida, dela partiriam como de um sonho, deixando tudo cá na terra, viveriam com mais sabedoria e afligir-se-iam menos ao morrerem. Agora, porém, quando, esperando gozar dos bens presentes, se lhes apresenta o ministro [da Morte], que os chama e os arrasta, amarrando-os com uma febre ou um definhamento, ficam furiosos por serem assim arrastados, eles que nunca esperaram serem privados de tais bens. Realmente, que é que não faria aquele ali, o [tipo] que está a construir a sua casa muito afanosamente e que está sempre a pressionar os operários, se soubesse que levaria a obra até ao fim, mas que, mal colocasse o telhado, partiria [desta vida], deixando ao seu herdeiro o gozo da casa, e ele, desgraçado, nem sequer jantaria nela. Aquele outro ali, muito feliz porque a sua mulher lhe pariu um rapaz, que por esse facto convida os amigos para um banquete e quer pôr ao menino o nome do pai ${ }^{352}$, se

350 “cairá” (peseîtai: $\pi \varepsilon \sigma \varepsilon \hat{\imath} \tau \alpha \imath$ ) é a lição dos mss., que alguns editores modernos emendam para keísetai: $\kappa \varepsilon i ́ \sigma \varepsilon \tau \alpha \imath$ "ficará jazente", "ficará por terra”. Obviamente, a emenda moderna pretende evitar a repetição do verbo: "mesmo que caia (ou "se cair"), cairá". Para quê emendar os manuscritos?

351 "venenos": O texto diz, especificamente (mas no plural), “cicutas"...

352 "o nome do pai", ou seja, "do pai do menino" ou "do pai do... pai", quer dizer, "do avô". No caso do primeiro filho, ambas as decisôes eram usuais. 
soubesse que o menino morreria aos sete anos de idade, achas que ele se regozijaria com esse nascimento? A causa disto é que ele vê o venturoso pai daquele atleta que venceu em Olímpia, mas não repara no vizinho deste, que acompanha o funeral do filho, sem que ele próprio tenha conhecimento da trama de que o seu [filho] está pendente. Estás a ver aquelas pessoas que disputam a respeito dos limites [de propriedade] — e são tantas! - , bem como aqueles outros a amontoarem dinheiro... e depois, antes de se gozarem dele, sáo chamados por aqueles mensageiros e ministros de que falei.

18. CARONTE - Sim, estou vendo tudo isso, e agora percebo o que é que eles consideram agradável durante a vida, ou que coisa é essa, cuja privação os enfurece. Se considerarmos os seus reis, que parecem ser as pessoas mais felizes do mundo, além da instabilidade, como tu dizes, e da incerteza da sorte, verificaremos que, no seu caso, as situações desagradáveis são em número superior às agradáveis, [como por exemplo] temores, perturbaçōes, inimizades, conspiraçōes, rancores e lisonjas. De facto, eles convivem com tudo isto. E deixo de lado os lutos, as doenças e os padecimentos, que obviamente os atacam em pé de igualdade [com as outras pessoas]. Ora, se os seus males já são tão grandes, podes imaginar como serão os dos simples particulares.

19. Quero agora, ó Hermes, dizer-te com que é que me parecem comparáveis os homens e toda a sua vida. Já viste alguma vez umas bolinhas na água, originadas pela queda impetuosa de uma torrente? Refiro-me àquelas bolhas de água donde se eleva uma espuma. Ora, algumas destas [bolhas] são muito pequenas, rebentam e desaparecem, enquanto outras se mantêm durante mais tempo, e então estas, pelo facto de outras [bolhas] se lhes juntarem, crescem, atingindo um volume muito grande, mas até mesmo essas acabam, mais tarde ou mais cedo, por rebentar... e nem poderia ser de outra maneira. Tal é a vida do homem: Todos são gerados por um certo sopro, uns por um [sopro] maior, outros por um [sopro] mais pequeno. Uns têm um sopro pouco duradoiro e de morte rápida, enquanto outros, mal se formam, logo deixam de existir. Portanto, todos têm necessariamente de "rebentar"353.

353 "rebentar", em sentido próprio relativamente às bolhas; em sentido figurado, "morrer", relativamente aos humanos. 
HERMES - Ó Caronte, a tua comparação não fica a dever nada a Homero, o qual compara o género humano com as folhas ${ }^{354}$.

20. CARONTE - E sendo eles como são, ó Hermes, tu bem vês como se comportam, como são gananciosos, competindo uns com os outros pelo poder, pelas honrarias e pelos bens materiais, tudo coisas que terão de abandonar, quando tiverem de vir cá para o nosso reino, trazendo consigo um único óbolo. Por isso, e já que nos encontramos num sítio elevado, queres que eu lhes brade em altas vozes, aconselhando-os, por um lado, a absterem-se de trabalhos vãos, e, por outro lado, a viverem com a morte sempre diante dos olhos, e que lhes diga. "Ó vâs criaturas, porque é que vos ocupais de tais coisas? Cessai de vos afadigar, pois não vivereis para sempre. Não é eterna nenhuma de entre as coisas que aqui [na terra] são veneráveis, $e$ ninguém, depois de morto, levará consigo nenhuma delas, mas, pelo contrário, é forçoso que parta completamente nu, e que a sua casa, o seu campo, o seu ouro pertençam sucessivamente a outros e passem para outros donos." Se eu lhes gritasse, de maneira que eles me ouvissem, estes conselhos e outros do mesmo género, não achas que retirariam daí grandes benefícios e se tornariam muitíssimo mais sensatos?

21. HERMES - Ó meu caro, tu não sabes como a Ignorância e o Engano os amoldaram, de tal modo que os seus ouvidos nem com uma broca podem ser abertos, tal foi a quantidade de cera com que os entupiram, como Ulisses fez ao seus companheiros, com receio de que eles escutassem as Sereias ${ }^{355}$. Como queres que eles possam ouvir-te, mesmo que tu rebentasses a gritar? De facto, aquilo que, entre vós, o Lete ${ }^{356}$ é capaz de fazer, aqui [na terra] fá-lo a Ignorância. No entanto, há algumas pessoas, embora poucas, que, por náo terem posto cera nos ouvidos, se

${ }^{354}$ Cf. Homero, Iliada, VI, 146: "Assim como é a geração das folhas, assim também a dos homens".

${ }^{355}$ Referência ao célebre episódio do canto XII da Odisseia: Enquanto os companheiros tinham os ouvidos tapados com cera, Ulisses, querendo escutar as Sereias em segurança, ordenou que o amarrassem fortemente ao mastro, de forma que não pudesse soltar-se e precipitar-se na sua perdição.

${ }^{356}$ Lete — recorde-se — é o rio do esquecimento. 
dirigem no sentido da verdade, olham agudamente as coisas e sabem como elas [realmente] são.

CARONTE - Nesse caso, gritemos a esses tais [indivíduos]. HERMES - É escusado dizer-lhes o que eles já sabem. Estás vendo como, eles afastados da maioria, riem dos acontecimentos e não estão mesmo nada satisfeitos com isso, mas é evidente que estão desejosos de se evadirem da vida e irem até vós. $\mathrm{Na}$ verdade, tornaram-se odiados, por criticarem a ignorância das pessoas.

CARONTE - Muito bem, seus valentes!... Mas, ó Hermes, eles são muitíssimo poucos...

HERMES - Pois sim, mas são suficientes ${ }^{357}$... Bem, agora desçamos.

22. CARONTE - Ainda desejava saber mais uma coisa, ó Hermes. Depois de me mostrares essa tal coisa, terás concluído perfeitamente o teu trabalho de guia: [desejo] ver os túmulos onde enterram os corpos.

HERMES - A essas tais coisas, ó Caronte, chamam eles campas, jazigos, sepulturas. Estás a ver, à entrada das cidades, aqueles montes de terra, aquelas colunas [funerárias] e aquelas pirâmides? Todas essas coisas são receptáculos dos mortos e lugares onde guardam os corpos.

CARONTE - E porque é que aqueles acolá póem coroas nas pedras [tumulares] e as untam com perfume, enquanto outros erguem uma pira em frente dos túmulos, ou abrem uma cova onde assam esses requintados manjares, e despejam nessas covas, segundo me parece, vinho e hidromel?

HERMES — Eu não sei, ó barqueiro, que utilidade têm essas coisas para os que estão no Hades. No entanto, as pessoas estão convencidas de que as almas, subindo lá de baixo e esvoaçando em volta, “jantam”, à sua maneira, o odor das carnes e o fumo, e bebem o hidromel da cova.

CARONTE - O quê? Esses tipos, cujas caveiras estão completamente secas, ainda bebem e comem? Eu seria bem ridículo, se te dissesse tais coisas, [logo] a ti, que todos os dias os conduzes lá para baixo. Ora, tu é que sabes se eles podem [ou não] subir cá à terra, uma vez tornados seres subterrâneos. Eu, que já tenho já tantas tarefas, passaria por uma situação bem ridícula, ó Hermes, se tivesse, não apenas de os levar lá para

${ }^{357}$ Hermes (Luciano) refere-se, naturalmente, ao cínicos e aos estóicos. 
baixo, mas também de os levar lá acima a fim de beberem... Ó seres frívolos! Ó insensatez! Vós não sabeis por que intransponíveis fronteiras se encontram separados o mundo dos mortos e o mundo dos vivos, nem como são as coisas cá entre nós ${ }^{358}$ :

Igual na morte é o homem, | tenha ou não tenha jazigo; A mesma honra tem Iro ${ }^{359} \mid$ que tem o nobre Agamémnon; Igual ao feio Tersites ${ }^{360} \mid$ é o filho da bela Tétis. Todos não passam de crânios | inconsistentes de mortos, todos nus e descarnados, | por esse prado de asfódelo ${ }^{361}$.

23. HERMES - Por Héracles! Como tu absorves e despejas $^{362}$ tanto Homero!... Mas, já que me lembraste, quero mostrar-te o túmulo de Aquiles. Estás vendo aquela [elevação] ali, sobranceira ao mar? É o [promontório] Sigeu, na Tróade; em frente deste, no [promontório] Reteu, está sepultado Ájax.

CARONTE - Esses túmulos, ó Hermes, não são lá muito grandes... Mas agora mostra-me essas famosas cidades, de que ouvimos falar lá em baixo: a Nínive de Sardanapalo, Babilónia, Micenas, Cleonas, e sobretudo a própria Tróia. Sim, recordo-me de ter passado muitos homens vindos dessa cidade, de tal modo que, durante dez anos inteiros, náo tive sequer vagar de pôr a barca em terra, a secar.

HERMES - Ó barqueiro, Nínive foi completamente arrasada, sem deixar sequer um vestígio, de tal modo, que não serias capaz de dizer onde ela se localizava. Quanto a Babilónia, é aquela ali, de belas torres e com uma grande muralha, [cidade] que, dentro de náo muito tempo, terá de ser procurada [entre ruínas], como Ninive. No que respeita a Micenas e a Cleonas,

${ }^{358}$ Estes versos são inspirados de diversos passos da Ilíada e da Odisseia.

${ }^{359}$ Iro (ou Arneu) é um mendigo insolente de Ítaca, a quem Ulisses aplicou um correctivo (Odisseia, XVIII, 5...).

360 Tersites era o mais feio de entre os gregos que tomaram parte na guerra de Tróia; o filho de Tétis é Aquiles. Note-se que o texto não diz "bela Tétis", mas "Tétis de bela cabeleira" — necessidade métrica do tradutor.

${ }^{361} \mathrm{O}$ asfódelo é uma "planta liliácea, de raiz tuberosa e belas flores ornamentais" ("Lello"). Julgo tratar-se de uma espécie de lírio ("Olhai os lírios do campo...”). Trata-se de uma ornamentação paradisíaca da zona dos bem-aventurados...

362 "absorves e despejas": o verbo epantléo (c̉ $\pi \alpha \nu \tau \lambda \dot{\varepsilon} \omega)$ engloba esses dois sentidos... 
até me envergonho de tas mostrar, bem como Ílion ${ }^{363}$, pois estou convencido de que, ao desceres lá abaixo, esganarias o Homero, pela magniloquência dos seus versos. E no entanto, essas cidades foram, no passado, muito prósperas, mas actualmente estão mortas. Sim, ó barqueiro, as cidades também morrem, tal como os homens, e até mesmo - o mais estranho de tudo — rios inteiros. Em Argos, não ficou sequer o leito do Ínaco ${ }^{364}$.

CARONTE - Mas que elogios, ó Homero! Que adjectivação! Ílion "sagrada”, "de largas ruas", Cleonas ${ }^{365}$ "de bela construçấo"...

24. ... Mas, enquanto nós estamos para aqui a falar... Quem são aqueles ali a lutar? Porque é que estão a matar-se uns aos outros?

HERMES - Estás a ver, ó Caronte, os Argivos e os Lacedemónios, assim como o famoso general Ortríades, moribundo, a escrever no troféu [da vitória] com o seu próprio sangue ${ }^{366}$.

CARONTE - Mas então, ó Hermes, em disputa de quê é que é a guerra?

HERMES - Em disputa do próprio território onde estão a lutar.

CARONTE - Mas que grande insensatez! Eles não sabem que, mesmo que cada um obtivesse todo o Peloponeso, apenas receberão de Éaco o espaço de um pé. Além disso, hoje uns, amanhã outros, cultivarão muitas vezes esta planície e arrasarão pela base aquele troféu.

HERMES - Na verdade, assim acontecerá... Quanto a nós, desçamos, ponhamos outra vez as montanhas no seu lugar e

363 Ílion é outro nome de Tróia.

364 Ínaco era um deus e um rio (um deus-rio) da Argólida. O texto diz "não ficou sequer o túmulo de Ínaco", mas o contexto (até rios desaparecem) leva-nos a acentuar a ideia de rio Ínaco, mais do que a de rei Inaco.

365 Homero não menciona Cleonas, mas o epíteto, esse é homérico...

366 Trezentos argivos e trezentos lacedemónios disputavam o território de Tireátide (Tírea), na Argólida, anteriormente ocupado pelos Lacedemónios. Dos seiscentos combatentes, morreram todos, menos três: dois argivos, que se retiraram, a fim de irem a Argos anunciar a vitória, e o general lacedemónio Ortríades, que, semimorto e todo ensanguentado, ainda teve forças para erguer um "troféu” e inscrever nele, com o próprio sangue, a... grande vitória dos Lacedemónios... 
retiremo-nos, eu para [cumprir] aquilo por que fui enviado, e tu para a tua barca. Em breve eu próprio irei até ti, levando-te mortos.

CARONTE - Prestaste-me um bom serviço, ó Hermes, e por isso serás inscrito para sempre como meu benfeitor, pois, graças a ti, lucrei alguma coisa com a minha viagem. Que grandes preocupaçôes têm os infelizes dos humanos: reis, barras de ouro, hecatombes ${ }^{367}$, batalhas... e sobre Caronte... nem uma só palavra! ${ }^{168}$

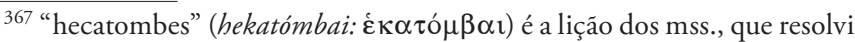

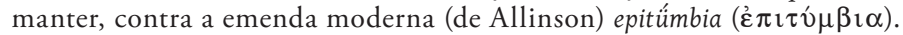

${ }^{368}$ Paródia das Rãs de Aristófanes, em que o criado Xântias diz e repete, em aparte (vv. 107 e 115), "E a meu respeito, nem uma palavra". 
SOBRE OS SACRIFÍCIOS 
(Página deixada propositadamente em branco) 


\section{INTRODUÇÁo}

Este opúsculo Sobre os Sacrifícios vem na linha dos filósofos cépticos, cínicos e epicuristas, que, nuns casos, e na sua doutrina mais radical, negam pura e simplesmente a própria existência dos deuses, e, noutros casos, sem chegarem a essa atitude negativista, entendem que as divindades não se ocupam nem se preocupam com o que se passa entre os humanos, cujos ritos, pretensamente "piedosos", são não só inúteis, como, sobretudo, absurdos.

Este estudo Sobre os Sacrifícios parte do princípio de que os deuses existem... princípio teórico, ou seja, para efeitos de raciocínio. Desde já se diga, porém, que a conclusão subtilmente implícita, resultante dos vários absurdos desse princípio teórico e do próprio comportamento atribuído, também, ao deuses, é a de que estes não existem... nem fazem falta. De facto, se existem, dão aos humanos um triste paradigma de comportamento, que lhes retira toda a sua suposta superioridade e daí, naturalmente, a própria razão de existirem.

Melhor do que qualquer paráfrase, prefiro citar textualmente o início deste opúsculo $(\$ 1)$ :

"Não sei se haverá alguém tão sisudo e tão melancólico, que não se ria da estupidez dos actos [humanos], ao ver como esses loucos procedem nos sacrifícios, nas festas e nas procissóes em honra dos deuses, o que lhes pedem e lhes suplicam, o que pensam a respeito deles. Mas, muito antes — julgo eu — de esse alguém se rir, deve perguntar a si próprio se a tais individuos deve chamar piedosos ou, pelo contrário, inimigos dos deuses e uns miseráveis, que fazem da divindade uma ideia tão baixa e ignóbil, a ponto de [os deuses] necessitarem dos homens, de sentirem prazer em serem lisonjeados e de ficarem irritados quando os desprezam."

Luciano, todavia, ocupa-se náo apenas dos aspectos rituais relativos aos sacrifícios (em que a relação entre humanos e divinos é meramente mercantil, segundo a concepção corrente, que os Romanos exprimiam por do, ut des "dou, para que me dês"), mas também do comportamento imoral dos deuses o que constitui, do ponto de vista da composição, uma "fuga ao tema"... Mas o Autor sabe muito bem que uma coisa tem muito (ou tudo) que ver com a outra. 
O referido aspecto mercantilista está magnífica e corrosivamente criticado no $\$ 2$ :

"[Os deuses] não fazem nada do que fazem, sem serem remunerados, mas, pelo contrário, vendem os seus serviços aos homens, $e$ então é possivel comprar-lhes a saúde por, digamos, um bezerro; a riqueza por quatro bois; a realeza por uma hecatombe; o regresso são e salvo de Ilion até Pilo por nove touros; a viagem maritima de Aulide para Ílion, por uma virgem real; e Hécuba pretendia comprar a Atena, por doze bois e um vestido, a graça de a cidade não ser tomada naquele momento. Podemos imaginar muitas coisas que os deuses podem vender por um galo, por uma coroa ou por um só grão de incenso."

Deuses desta laia, dispensamo-los bem (quer existam, quer não existam); e quanto a esta humanidade, é óbvio que não podemos, simplesmente, dispensá-la, mas tentar reformar-lhe a mentalidade - para o que Luciano contribui com uma parte muito voluntariosa, embora de eficácia duvidosa. Leia-se o final (\$15):

"Perante estas práticas e estas superstições da maior parte das pessoas, creio que elas necessitam não [propriamente] de um censor, mas sim de um Heraclito ou de um Demócrito - um para troçar da sua ignorância, e o outro para lamentar a sua insensatez." 


\section{Sobre os SACRIfícios}

1. Não sei se haverá alguém tão sisudo e tão melancólico, que náo se ria da estupidez dos actos [humanos], ao ver como esses loucos procedem nos sacrifícios, nas festas e nas procissôes em honra dos deuses, o que lhes pedem e lhes suplicam, o que pensam a respeito deles. Mas, muito antes - julgo eu de esse alguém se rir, deve perguntar a si próprio se a tais indivíduos deve chamar piedosos ou, pelo contrário, inimigos dos deuses e uns miseráveis, que fazem da divindade uma ideia tão baixa e ignóbil, a ponto de [os deuses] necessitarem dos homens, de sentirem prazer em serem lisonjeados e de ficarem irritados quando os desprezam.

Assim, as desgraças ocorridas na Etólia, as calamidades dos Calidónios, tantas e tantas mortes, a consumição de Meleagro ${ }^{369}$, tudo isso, segundo se diz, foi obra de Ártemis, despeitada por não ter sido convidada por Eneu ${ }^{370}$ para um sacrifício ${ }^{371}$ : a tal ponto lhe ficou gravada a sua exclusão dos sacrifícios. Até se me afigura vê-la, abandonada lá no céu, dizendo impropérios e toda irritada por ter sido excluída de uma tão grande celebração, enquanto os restantes deuses haviam ido a casa de Eneu.

2. Por outro lado, diríamos que os Etíopes são bem-aventurados e três vezes felizes, pelo facto de Zeus se recordar da amabilidade que para com ele haviam demonstrado, [no início do poema de Homero $^{372}$ ] banqueteando-o durante doze dias, bem como aos outros deuses que ele trouxera consigo.

369 "a consumição de Meleagro": As Moiras (Meras) profetizaram que o menino (então com apenas sete dias) morreria quando um tição da lareira se consumisse. A fim de contrariar o destino, sua mãe apagou o dito tiçáo e conservou-o inalterado em lugar seguro... Como "ninguém foge ao seu destino", foi a própria mãe de Meleagro que, deliberadamente (história longa de contar), reacendeu o tição e o deixou consumir-se, ao mesmo tempo que Meleagro se consumia também. Mas a causa real de todas estas desgraças foi Artemis... ...

${ }^{370}$ Eneu era o pai de Meleagro.

${ }^{371}$ Eneu, no final de ricas colheitas, consagrou as primícias do cereal a Ceres; o vinho a Dioniso; o azeite a Atena; esqueceu-se, porém, de Ártemis. Ora, como diz Ovídio (Metamorfoses, VIII, 279), tangit et ira deos, "a cólera também toca os deuses”, donde a implacável sede de vingança de Ártemis.

372 A frase, inicialmente um comentário (escólio) de copista, passou para o corpo do texto em todos os manuscritos. De resto, a localização do 
Deste modo, segundo parece, [os deuses] náo fazem nada do que fazem, sem serem remunerados ${ }^{373}$, mas, pelo contrário, vendem os seus serviços aos homens, e entâo é possível comprar-lhes a saúde por, digamos, um bezerro; a riqueza por quatro bois ${ }^{374}$; a realeza por uma hecatombe; o regresso são e salvo de Ílion até Pilo por nove touros; a viagem marítima de Áulide para Ílion, por uma virgem real; e Hécuba pretendia comprar a Atena, por doze bois e um vestido, a graça de a cidade náo ser tomada naquele momento. Podemos imaginar muitas coisas que os deuses podem vender por um galo, por uma coroa ou por um só gráo de incenso.

3. Foi sabendo disso, que, julgo eu, Crises, na qualidade de sacerdote, de velho e de perito nas coisas divinas, ao afastar-se de Agamémnon sem nada ter conseguido, como se tivesse feito previamente um empréstimo a Apolo, justifica a graça [pedida], reclama o pagamento, e por pouco que não o ofendia, dizendo: "Ó meu caro Apolo 375 , fui eu que pus coroas no teu templo, até então desprovido de coroas, fui eu que assei no teu altar, em tua honra, coxas de touros e de cabras, e tu agora desprezas-me nesta aflição e não fazes caso do teu benfeitor." E de facto, Crises comoveu a tal ponto o deus, que este sacou das flechas e, tendo-se colocado por cima do cais dos navios, atingiu com a peste os Aqueus $^{376}$ e, com eles, as mulas e os cães.

4. Ora, uma vez que recordei Apolo, quero agora mencionar outros episódios, que a seu respeito os sábios mencionam, não aqueles em que o deus foi infeliz nos amores, nem a morte de Jacinto, nem o desprezo que Dafne lhe votou, mas sim o facto de ter sido condenado pela morte dos Ciclopes e, por via disso, ter sido ostracizado do céu e enviado para a terra, a fim de experimentar a condição humana, quando serviu como escravo na Tessália, em casa de Admeto, e depois na Frígia, em casa de Laomedonte; em casa deste, porém, năo estava só, mas sim

\footnotetext{
passo é muito vaga: na verdade, trata-se de Ilíada, I, 423 e $494 \ldots$

${ }^{373}$ Os Romanos, com o seu espírito mercantilista, diziam, referindo-se a um deus: do, ut des, "dou-te, para que me dês".

374 "bois": Na verdade, boûs ( "vaca".

${ }^{375}$ Luciano póe o sacerdote a dirigir-se a Apolo em tom coloquial...

376 "Aqueus" é, em Homero, a designação normal dos Gregos...
} 
juntamente com Posídon, ambos obrigados pela necessidade a carregar tijolos e a edificarem a muralha. E mesmo assim, não receberam do frígio o salário por inteiro, pois este ficou a dever-lhes, segundo se diz, mais de trinta dracmas troianas,

5. Não é verdade que os poetas narram com toda a gravidade estes episódios passados com os deuses, nomeadamente alguns, muito mais sagrados, a respeito de Hefesto, de Prometeu, de Crono, de Reia e, enfim, de quase toda a casa de Zeus?... E [fazem] isto, invocando as Musas, no início dos poemas, para cantarem em coro com eles, e, aparentemente inspirados por elas, cantam o modo como Crono, assim que castrou seu pai Úrano, se tornou rei em seu lugar e devorou os próprios filhos, como mais tarde fez o argivo Tiestes; e Zeus, escondido por Reia, que pôs no seu lugar uma pedra, foi exposto em Creta, onde foi alimentado por uma cabra, tal como Télefo o foi por uma corça como o persa Ciro por uma cadela; mais tarde, Zeus expulsou o próprio pai, lançou-o no cárcere e tomou o poder; depois desposou muitas outras mulheres, a última das quais a sua irmã [ $\mathrm{Hera}^{377}$, segundo o costume dos Persas e dos Assírios. De temperamento apaixonado e muito dado aos prazeres de Afrodite, facilmente encheu o céu de filhos, tendo gerado uns das deusas suas iguais, enquanto outros eram bastardos, de raça mortal e terrena, e para isso o galante transformava-se ora em [gotículas de] oiro, ora em touro, ora em cisne, ora em águia... enfim, mais mutável que Proteu. Somente Atena, que ele concebeu totalmente dentro do seu cérebro, é que brotou da sua própria cabeça. Quanto a Dioniso, [Zeus,] tendo-o retirado à pressa, meio formado, segundo se diz, do ventre de sua mãe enquanto esta ardia ${ }^{378}$, pegou no menino e introduziu-o dentro da própria coxa, na qual depois, chegado o momento do parto, fez uma incisão.

6. [Os] poetas cantam casos semelhantes a estes a respeito de Hera, [dizendo] que esta, sem ter tido qualquer relaçáo com

377 Só os manuscritos do grupo $\beta$ é que especificam o nome Hera, o que pode dever-se a uma anotação à margem ou na entrelinha, que passou para o texto...

378 "sua mãe...": Sémele, filha do fundador de Tebas, Cadmo. Tendo pedido a Zeus, seu amante, que se lhe revelasse tal como era, em todo o seu fulgor, morreu instantaneamente carbonizada. 
o marido, gerou, sem fecundação [masculina] ${ }^{379}$, um menino, Hefesto, criatura, aliás, nada bafejada pela sorte, pois é um operário $^{380}$, um ferreiro, um forjador, que vive sempre no meio do fumo, coberto de escórias, como qualquer forneiro, e ainda por cima com pernas desiguais. De facto, ficou coxo devido a uma queda, quando Zeus o lançou do alto do céu; e se os habitantes de Lemnos não tivessem feito a boa acção de o apanhar quando ele ainda vinha no ar, lá teria morrido o nosso Hefesto, como aconteceu com Astíanax ${ }^{381}$, atirado do alto da torre.

Mesmo assim, o caso de Hefesto é só relativamente grave. Mas quem não conhece Prometeu, com tudo aquilo que ele padeceu, pelo facto de ser excessivamente filantropo? De facto, Zeus levou-o para a Cítia, crucificou-o no Cáucaso e pôs-lhe uma águia a devorar-lhe todos os dias o fígado ${ }^{382}$.

7. Este, pelo menos, cumpriu uma sentença condenatória. Mas, pelo contrário, como não falar de Reia - realmente, há que referir também este caso — , que, já velha, fora de idade e mãe de tantas divindades, se comportou vergonhosamente e cometeu actos horríveis, ao apaixonar-se por jovens e revelando-se muito ciumenta, levando consigo Átis num carro puxado por leões, mesmo que este jovem náo pudesse ser-lhe útil? ${ }^{383}$. Assim sendo, como deixar de censurar Afrodite por cometer adultério, ou Selene pelo facto de, tantas vezes, a meio da sua viagem, descer do céu, a fim de contemplar o seu [querido] Endímion?384

379 "fecundação [masculina]": cf. a expressão ōiòn hüpēnémion (⿳亠丷厂犬v

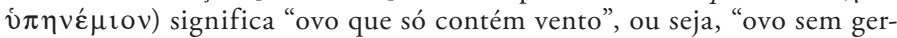
me", "ovo não fecundado". Luciano deve ter-se inspirado nesta expressão. 380 “operário ... ferreiro ... forjador ... forneiro”, são, em grego, vocábulos se sentido muito próximo (incluindo o primeiro, no seu sentido mais especial).

381 "Astíanax" (outras forma, menos usada: Astianacte), filho de Heitor e de Andrómaca, depois da queda de Tróia, foi, ainda bebé, lançado do alto de uma das torres da cidade.

382 É claro que a história acrescenta que o fígado, à medida que ia sendo devorado, também ia crescendo...

383 Átis havia-se castrado, num acesso de loucura...

${ }^{384}$ Endímion, formoso pastor, a quem Zeus concedeu o desejo de dormir eternamente, pelo que também se mantinha sempre jovem, Selene (a Lua), ao passar, apaixonou-se pelo "belo adormecido", a ponto de descer à terra, para melhor o contemplar... 
8. Mas deixemo-nos de palavreado e subamos ao próprio céu, poeticamente voando através do caminho indicado por Homero e por Hesíodo, e observemos como se organizam as coisas lá em cima. O seu exterior é de bronze, como já antes da nossa visita havíamos ouvido Homero referir. Subindo mais e elevando um pouco o olhar para o alto, para a abóbada celeste, vemos uma luz muito brilhante, um sol muito puro, astros muito cintilantes, onde é sempre dia e o pavimento é de ouro. Para quem entra, as Horas habitam a primeira moradia, pois são elas as porteiras [do céu]; depois, temos Íris e Hermes, ministros e mensageiros de Zeus; a seguir, está a oficina de Hefesto, pejada de todas as ferramentas do ofício; mais adiante, [enfim,] ficam as moradas dos deuses e o palácio de Zeus, tudo obras de extrema beleza, pois foram decoradas por Hefesto.

9. "Nos paços de Zeus sentados, | os deuses..." - sim, em lugar tão alto, há que usar, creio eu, um estilo elevado - baixam os olhares para a terra e olham a toda a volta, sondando, no intuito de verem subir lume de algum lugar, ou elevar-se um odor a carne assada, “... | em espiral por entre of fumo"385. E se alguém estiver fazendo um sacrifício, todos se banqueteiam, de bocas escancaradas viradas para o fumo, e bebem o sangue vertido nos altares, como fazem as moscas. Quando, porém, tomam as refeiçóes nas suas casas, o seu alimento é de néctar e ambrósia ${ }^{386}$. Outrora, os humanos comiam e bebiam com eles, como, por exemplo, Íxion e Tântalo. Como, porém, eram insolentes e muito tagarelas, foram, e continuam a ser, punidos, pelo que o céu é inacessível e interdito ao género humano.

10. Tal é a vida dos deuses. Portanto, os homens, em matéria de religião, praticam actos consentâneos e consequentes com tudo isso. Antes de mais, demarcaram bosques, dedicaram montanhas, consagraram aves e atribuíram plantas a cada um dos deuses; depois, tendo-os distribuído por naçóes, veneram-nos e declara-nos seus cidadãos: Apolo foi adoptado pelos Délfios, bem como pelos Délios, Atena pelos Atenienses - como o comprova a semelhança do nome —, Hera pelos

${ }^{385}$ Ilíada, I, 317, 2o hemistíquio.

${ }^{386} \mathrm{O}$ néctar e a ambrósia eram respectivamente, a bebida e a comida dos deuses; fabricados à base de mel, conferiam a imortalidade. 
Argivos, Reia pelos Migdónios ${ }^{387}$, Afrodite pelos Páfios. Por sua vez, os Cretenses não só afirmam que Zeus nasceu e foi criado na sua terra, mas até mostram o seu túmulo, pelo que nós andamos há muito tempo enganados, cuidando que é Zeus quem troveja, quem chove $^{388}$ e quem executa todos os outros fenómenos, quando ele, afinal, e sem nós darmos por isso, há muito que morreu e está sepultado em Creta.

11. Entấo, [os homens] erigem-lhes templos, sem dúvida para que eles não fiquem sem tecto e sem lar, representam imagens suas, chamando [para isso] um Praxíteles, um Policlito ${ }^{389}$ ou um Fídias... mas eu não sei com que base visual é que estes [artistas] representam Zeus barbudo, Apolo como um perpétuo adolescente, Hermes com barbicha, Posídon com cabelos azuis e Atena de olhos Atena verde-mar ${ }^{390}$. E no entanto, os que entram no templo cuidam estar a ver, não o marfim vindo da Índia, nem o ouro extraído das minas da Trácia, mas sim o próprio filho de Crono e de Reia ${ }^{391}$, transferido para a terra por Fídias, encarregado de vigiar o deserto de Pisa ${ }^{392}$ e muito feliz, se alguém, de quatro em quatro anos completos $^{393}$, lhe oferece um sacrifício como acto acessório dos Jogos Olímpicos.

${ }^{387}$ Migdónia, ou Frígia, onde prosperava o culto de Cíbele, a deusa-mãe, também denominada Reia.

388 "quem chove": Em grego, o verbo hüein (v́عı) pode perfeitamente ter como sujeito "Zeus": "Zeus chove", ou seja... "Zeus faz chover"...

389 Policlito: a forma gr. Polúkleitos (По $\lambda \hat{\kappa} \kappa \lambda \varepsilon \imath \tau \circ \varsigma)$ passou para lat., segundo regra normal, para Polyclitus, que justifica a forma port. com -i-; epigraficamente, no entanto, também está registada, em lat., a forma Polyclètus, igualmente legítima (cf. lat. Alexandrèa e Alexandrīa, Darēus e Darius...). Apesar de o uso port. pender para Policleto, nada (mesmo nada!) impede a forma Policlito. O gr. - ei- evoluiu, ainda em grego, para [-e-] e, logo a seguir, para [-i- $]$, embora (com excepção de grafias populares, aliás

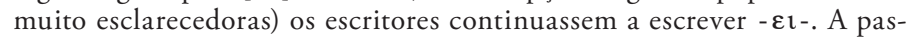
sagem destas palavras para latim $(-\bar{e}-\mathrm{e}-\bar{i}-)$ reflecte as pronúncias gregas.

390 "olhos verde-mar", "olhos cinzentos", "olhos brilhantes", "olhos de coruja”... creio que nem os gregos se entendiam lá muito bem com a caracterização destes olhos.

391 O "filho de Crono e de Reia" é Zeus.

392 Regiáo da Élide, a oeste do Peloponeso e perto de Olímpia.

393 "de quatro em quatro anos completos": O gr. diz "durante (ou no espaço de) cinco anos”... maneira de contar... 
12. Uma vez erguidos os altares, feitas as proclamaçóes preliminares e as aspersóes [lustrais], trazem as vítimas: O lavrador traz um boi de trabalho, o pastor um cordeiro, o cabreiro uma cabra, um outro [traz] incenso ou um bolo, o pobre torna o deus propício, somente beijando-lhe a mão direita. Então os ofertantes - e regresso ao assunto ${ }^{394}$ — tendo coroado o animal e tendo examinado com muita antecedência se ele se encontra em perfeito estado, a fim de náo imolarem nenhum inutilizável, conduzem-no ao altar, onde matam à vista do deus o animal, que muge tristemente, sinal claro de bom augúrio, secundando, já a meia voz, a flauta que acompanha o sacrifício. Quem não imaginaria que os deuses se comprazem ao verem este espectáculo?...

13. ... Uma inscrição avisa de que não deve aproximar-se do vaso lustral quem não tiver as mãos limpas ${ }^{395}$... mas o próprio sacerdote fica todo coberto de sangue, como o célebre Ciclope ${ }^{396}$, ao esquartejar [a vítima], separando-lhe as entranhas, arrancando-lhe o coração, vertendo o sangue à volta do altar... enfim... que ritual não pratica ele, que não seja piedoso? Por fim, acende uma fogueira, lança nela uma cabra com a sua pele ou uma ovelha com a sua lá. Então o odor divino e sacrossanto a carne assada sobe por esses ares e espalha-se lentamente pelo céu. Os Citas, porém, desprezam todas as vítimas deste género, por considerá-las muito modestas, pelo que oferecem seres humanos a Ártemis, e é assim que eles agradam a essa deusa.

14. Todos esses rituais talvez ainda sejam moderados, bem como os praticados pelos Frígios e pelos Lídios; se, porém, fores ao Egipto, então... então sim, verás muitas coisas venerandas e verdadeiramente dignas do céu, como Zeus com cabeça de carneiro, o belíssimo Hermes com cabeça de cão, Pá todo na

${ }^{394}$ De facto, o Autor havia-se esquecido do tema principal do seu opúsculo.

$395 \mathrm{O}$ adj. katharós ( $\kappa \alpha \theta \alpha \rho$ ós) significa "limpo", "sem mancha”... e, no sentido moral, "puro", "sem pecado"; aqui, o sentido de "limpo" é o que mais sobressai, não só por se aplicar a "mãos” (o que, em todo o caso, não impediria o sentido moral), mas sobretudo pela referência ao sacerdote, que, ao matar e retalhar a vítima, fica todo coberto de sangue.

396 Alusão ao episódio do Ciclope no canto IX da Odisseia, especialmente os vv. 288-293, em que o Ciclope devora completamente dois companheiros de Ulisses. 
figura de um bode, um outro na forma de uma íbis ou de crocodilo, outro ainda na forma de macaco... Mas...

se queres saber tais coisas, | e conhecê-las a fundo,

escutarás muitos sábios, escribas e profetas de cabeça rapada, que vos contarão - não sem antes pronunciarem a frase: "Vós, profanos, cerrai as vossas portas" - como os deuses, aterrorizados com a guerra e a revolta dos Gigantes, fugiram para o Egipto, a fim de escaparem aos seus inimigos. Depois, cheios de medo, um deles entrou no corpo de um bode, outro no [corpo de] um carneiro, outro no de um animal selvagem, outro no de uma ave, e é por isso que ainda hoje os deuses conservam as formas desse tempo. É claro que todas estas histórias estão na parte reservada dos templos, e foram escritas há mais de dez mil anos.

15. De resto, os seus sacrifícios são idênticos aos nossos, com a diferença de que eles choram a vítima, colocam-se à sua volta e, depois de morta, ferem os próprios peitos. Outros, depois de imolarem a vítima, limitam-se a sepultá-la.

Ápis é para eles o deus mais importante. Quando ele morre, quem há que goste tanto do seu cabelo, que não o corte, patenteando na cabeça rapada toda a sua dor, ainda que tenha uma cabeleira purpúrea como a de Niso?397 Este Ápis é um deus tirado da boiada, aclamado para suceder ao anterior, por ser mais belo e mais majestoso que os bois vulgares.

Perante estas práticas e estas superstiçôes da maior parte das pessoas, creio que elas necessitam náo [propriamente] de um censor, mas sim de um Heraclito ou de um Demócrito um para troçar da sua ignorância, e o outro para lamentar a sua insensatez.

397 Niso, rei de Mégara. Diz a lenda (v. Ovídio, Metamorfoses, VIII, 1-151) que, enquanto ele conservasse os seus longos cabelos, a cidade náo poderia ser tomada. Foi traído pela própria filha... para que se cumprisse a profecia. Esta história faz lembrar a de Sansão e Dalila. 
FILOSOFIAS EM LEILÃO 
(Página deixada propositadamente em branco) 


\section{INTRODUÇẤO}

O título grego suscita alguma dificuldade: Biōn Prâsis (Bí $\omega v \Pi \rho \hat{\alpha} \sigma ı \varsigma)$ significa, literalmente, "Leiláo de Vidas", o que dá origem a diversos "arranjos" de tradução. Um desses arranjos (ediçōes francesas) opta por Sectes à l'encan, ou sejas, Seitas (ou Escolas) Filosóficas em Leilâo. A minha versão vai precisamente neste sentido: Filosofias em Leilâo. O que não é aceitável (e não era, como se verá, a intenção de Luciano) é entender como Filósofos em Leiláo, de algum modo sugerido pelo contexto geral da obra... mas Luciano, em obra imediatamente posterior (Os Ressuscitados ou O Pescador), jura "a pés juntos" que não se refere aos grandes nomes da Antiguidade, que ele respeita e venera, mas sim aos filósofos seus contemporâneos, os quais, na sua maior parte, se revelam indignos dos seus Mestres. As personagens trazidas a julgamento representam, no fundo, Modelos de Vida Filosóficos, não propriamente como eles foram teorizados desde há muito, mas sim como são praticados... quer dizer, como náo são praticados, ou ao contrário do que preconiza a doutrina.

O diálogo começa logo com os preparativos para o "espectáculo" do leiláo. Além de Zeus, que observa todo o processo, Hermes é o pregoeiro e vendedor; uma figura constante é a do Comprador; finalmente, e em sucessão, são postos em leiláo os diversos MODELOS: Pitagórico, Democrítico + Heraclítico (num só "pacote”!), Socrático, Cínico, Estóico, Epicurista e Céptico.

E oportuno dizer que, ao apresentar cada um dos Modelos Filosóficos, Hermes fornece-nos uma mais ou menos breve caracterizaçáo das respectivas doutrinas, facto que, para o leitor moderno, é um bom elemento de informação, se bem que esses "apontamentos" se refiram àquilo que cada doutrina tinha de mais popular ou mais "vistoso".

O primeiro MODELO, o PITAGÓRICO, é particularmente sugestivo: o seu representante é apresentado como um ecléctico, que conhece muitas ciências, como Aritmética, Astronomia, Charlatanice, Geometria, Música, Imposturice... Estás perante um adivinho consumado [itálico meu]... O leitor deter-se-á com mais vagar na algo longa leitura das muitas competências dos sequazes do pitagorismo (\$\$2-6). Segue-se (\$\$7-12) o MODELO CÍNICO, seguidor do truculento e anárquico Diógenes. Vêm a seguir, o MODELO ESTÓICO, o EPICURISTA, o 
CÉPTICO, o DEMOCRÍTICO e o HERACLÍTICO, o ACADÉMICO, o PERIPATÉTICO e, finalmente, o CÉPTICO, aos quais é atribuído um valor mais ou menos indecente.

Nitidamente, muitos contemporâneos (e inimigos) de Luciano terão entendido este diálogo como uma ofensa aos prestigiados fundadores ou teorizadores das diversas escolas filosóficas, o que obrigará Luciano (então sob o pseudónimo de Parresíades) a justificar-se em obra imediatamente posterior (Os Ressuscitados ou $O$ Pescador). Um aspecto que parecia particularmente escandaloso era o facto de serem postos em hasta pública homens livres; assim, o espectáculo, ainda que só imaginado e de valor meramente literário (o que, em todos os tempos, nem sempre foi assim entendido), era o de uma venda de escravos.

NOTA - Os dois diálogos (Filosofias em Leilão e Os Ressuscitados ou $O$ Pescador) podem, com proveito, ser lidos em confronto mútuo. Afinal, Luciano escreveu o segundo, como justificação e esclarecimento do primeiro. 


\section{Filosofias em Leilāo}

Personagens: Zeus, Hermes, um Mercador, MODELOS: PITAGÓRICO, DEMOCRÍTICO, HERACLÍTICO, SOCRÁTICO, CÍNICO, ESTÓICO, EPICURISTA, CÉPTICO.

1. ZEUS - Tu ai ${ }^{398}$, vai dispondo os bancos e preparando a sala para os que forem chegando; e tu ${ }^{399}$, traz as vidas [filosóficas] ${ }^{400}$ e coloca-as em fila, mas primeiro compóe-as bem, para que fiquem com bom aspecto e atraiam o maior número possível [de compradores]. E tu, Hermes, lança o pregáo e convoca as pessoas.

HERMES ${ }^{401}$ - Boa sorte aos compradores, e que se apresentem imediatamente na sala do leiláo. Vamos pôr à venda por pregão vidas filosóficas ${ }^{402}$ de toda a espécie e das mais variadas doutrinas. Se alguma pessoa, de momento, náo puder pagar em dinheiro vivo, depositará uma caução e pagará no próximo ano.

ZEUS ${ }^{403}$ - Está a vir aí muita gente; por isso, não devemos perder tempo nem fazê-los esperar. Iniciemos, pois, o leiláo.

2. HERMES - Quem queres que apresentemos em primeiro lugar?

ZEUS - Aqui este guedelhudo, o Jónio, pois tem ar de pessoa veneranda.

398 “Tu aî": Zeus dirige-se a um funcionário, e não a Hermes, pois dirige-se a este, logo a seguir, como outra personagem...

399 "e tu": Refere-se a outro funcionário.

${ }^{400} \mathrm{Na}$ fala seguinte, Hermes especifica mesmo: "vidas filosóficas" (v. nota).

${ }^{401}$ Os manuscritos não indicam mudança de personagem, o que não causaria dificuldade de maior. Em todo o caso, sigo uma emenda moderna ("Loeb”, Du Soul, Fritzsche, etc.)....

402 "vidas filosóficas", ou seja, "modelos filosóficos de vida"; o texto,



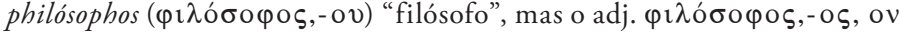
"filosófico". Quer isto dizer que náo se trata da venda das pessoas dos filósofos, mas dos diversos modelos de vida que cada um preconiza.

${ }^{403}$ Mais uma vez, sigo a distribuição de intervençōes da "Loeb", etc... 
HERMES - Tu, o [modelo de vida] Pitagórico ${ }^{404}$, desce daí e apresenta-te para seres examinado pelos circunstantes.

ZEUS - Ora apregoa-o.

HERMES - Ponho à venda o mais excelso modelo de vida, o mais venerando. Quem quer arrematá-lo? Quem quer estar acima da condição humana? Quem quer conhecer a harmonia do Universo e ressuscitar de novo?

COMPRADOR — De aspecto, não é nada vulgar... Mas que é que ele sabe especialmente bem?

HERMES - Aritmética, Astronomia, Charlatanice, Geometria, Música, Imposturice... Estás perante um adivinho consumado.

COMPRADOR - Posso interrogá-lo?

HERMES — Sim, interroga-o... e boa sorte.

3. COMPRADOR - Donde é que tu és?

MODELO PITAGÓRICO ${ }^{405}$ - De Samos.

COMPRADOR - Onde foste educado?

MODELO PITAGÓRICO - No Egipto, com os sábios desse país.

COMPRADOR - Mas vejamos: Se eu te comprar, que é que vais ensinar-me?

MODELO PITAGÓRICO - Não vou ensinar-te nada, mas somente fazer-te recordar.

COMPRADOR - Fazeres-me recordar... como?

MODELO PITAGÓRICO — Em primeiro lugar, purificarei a tua alma, limpando-a da sujidade que a cobre.

COMPRADOR - Pois bem, considera que eu já estou limpo: Qual o teu método de me fazer recordar?

404 "o Pitagórico": Rigorosamente, deve subentender-se "vida” "“[vida] pitagórica", ou "[modelo de vida] pitagórico". Recorde-se que bios (ßíos) é palavra masculina. Na sequência, a personagem "[Modelo de Vida] Pitagórico" surge, nos manuscritos, como "PITÁGORAS". Traduzirei por "MODELO PITAGÓRICO". Do mesmo modo, os "modelos de vida" seguintes.

${ }^{405}$ Os manuscritos têm PITÁGORAS, o que causaria certa dificuldade, pois náo se trata de vender esse e outros filósofos, mas sim o seu modelo de vida. Em todo o caso, a resposta do "MODELO" contém elementos da vida do filósofo. De notar, uma vez por todas, que as intervençóes do MODELO PITAGÓRICO são geralmente em dialecto jónico, usado por Pitágoras e seus seguidores. É impossível encontrar uma equivalência num "dialecto" português. Certos tradutores entendem verter numa linguagem mais ou menos arcaica... 
MODELO PITAGÓRICO — Antes de mais, uma longa tranquilidade, um mutismo [absoluto] e cinco anos completos sem falar com ninguém.

COMPRADOR - Ó meu caro, trata mas é de educar o filho de $\mathrm{Creso}^{406}$, pois eu quero ter o uso da fala, e não ser uma estátua... Mas então que é que acontece depois desse silêncio e dos tais cinco anos?

MODELO PITAGÓRICO — Serás exercitado na Música e na Geometria.

COMPRADOR - Tem graça isso que dizes: que primeiro tenho de tornar-me citaredo, e só depois serei sábio.

4. MODELO PITAGÓRICO - Depois dessas matérias, aprendes a contar.

COMPRADOR - Mas eu já sei contar...

MODELO PITAGÓRICO — Então como é que tu contas?

COMPRADOR - Um, dois, três, quatro...

MODELO PITAGÓRICO — Estás vendo? O que tu cuidas que são quatro, são $d e z$, ou seja, o triângulo perfeito ${ }^{407} \mathrm{e}$ o nosso juramento.

COMPRADOR - Então... [juro] por esse importantíssimo juramento, pelo Quatro!, nunca na minha vida tinha ouvido palavras mais divinas e mais santas.

MODELO PITAGÓRICO ${ }^{408}$ — Depois destas matérias, ó estrangeiro, ficarás a saber, a respeito da terra, do ar, da água

${ }^{406}$ Um dos filhos de Creso era mudo (ou surdo-mudo). Conta Heródoto (I, 34 e sobretudo 85) que o oráculo de Delfos, consultado a respeito da deficiência do moço, profetizara: "Ele falará num dia de calamidade". De facto, vendo o pai na iminência de ser morto, o moço gritou: "Ó homem, não mates Creso".

${ }^{407} \mathrm{O}$ triângulo perfeito (equilátero) é definido por uma pirâmide, cuja base tem quatro pontos, cuja segunda linha tem três pontos, a terceira tem dois, e a quarta e última (o vértice) tem um, ou, matematicamente, $1+2+3+4=10$. Naturalmente (o triângulo é equilátero) todos os lados contêm igualmente os quatro pontos:

408 Aqui, como noutros passos, o "Modelo pitagórico” usa não só o dialecto jónico, mas certa terminologia cujo sentido exacto nos escapa... 
e do fogo, como se processam as suas transformaçóes, qual as respectivas formas e como se movimentam.

COMPRADOR - Mas então o fogo, ou o ar, ou a água, têm forma?

MODELO PITAGÓRICO - Têm, pois, e bem visível. $\mathrm{Na}$ verdade, [estes elementos] não poderiam mover-se, caso fossem informes e disformes ${ }^{409}$. Além disso, ficarás a saber que a divindade é um número, e que o espírito é uma harmonia.

COMPRADOR - É fantástico isso que estás a dizer.

5. MODELO PITAGÓRICO - E depois de eu te explicar essas coisas, ficarás a saber que tu não és um só, nem aquele que pareces ser, mas um outro ser.

COMPRADOR - Que é que estás a afirmar? Que eu sou outro, e náo este que agora está a conversar contigo?

MODELO PITAGORICO — Neste momento, sim, és esta pessoa, no passado apareceste com outro corpo e com outro nome. Com o tempo, transmigrarás novamente para outro ser.

COMPRADOR - Queres tu dizer que eu serei imortal, ao transformar-me em muitas formas?... Bem, já basta...

6. ... Agora, quanto aos teus hábitos de vida ${ }^{410}$, que tipo de pessoa és tu?

MODELO PITAGÓRICO — Não como nada que tenha tido vida, e quanto ao resto, tudo, menos favas.

COMPRADOR - E porquê? Tens aversão às favas?

MODELO PITAGÓRICO — Não... mas é que elas são sagradas e de uma natureza maravilhosa. Em primeiro lugar, no seu todo ${ }^{411}$, fazem lembrar a procriação; e depois, se descascares uma vagem de fava ainda verde, verás que é [a fava] parecida, na sua forma, com os testículos do homem; e se a cozeres e a deixares um certo número de noites ao luar, produzirás [autêntico] sangue; mas — razão maior — os Atenienses têm por costume escolher os seus magistrados por meio de favas ${ }^{412}$.

409 "informes e disformes": Deve tratar-se (ainda por cima com a sua morfologia jónica), de termos técnicos do pitagorismo...

410 "hábitos de vida": O gr. diz diaita $\left(\delta^{\prime} \alpha \iota \tau \alpha\right)$, que deu o port. dieta, que é o sentido deste passo, mas que em grego é o menos usual.

411 "no seu todo", ou seja, as favas inteiras, não descascadas, que supostamente se parecem com o sexo masculino.

${ }^{412}$ Para a tiragem à sorte, havia duas urnas: uma com os nomes dos candidatos, e outra com favas brancas e pretas. Tiravam-se das urnas, 
COMPRADOR — Falaste tudo muito bem, falaste que nem um sacerdote... Mas agora, despe-te lá, pois quero observar-te todo nu... Ó Héracles! o tipo tem uma coxa de oiro! Parece ser, não um mortal, mas um deus. Por isso, vou já comprá-lo sem a mínima hesitação. Por quanto é que o leiloas?

HERMES - Dez minas ${ }^{413}$.

COMPRADOR - Fico com ele.

ZEUS - Escreve aí o nome do comprador e donde é que ele vem.

HERMES - Ó Zeus, parece ser um italiano qualquer da regiâo de Crotona, ou de Tarento, ou de alguma colónia grega aí estabelecida... mas não foi só um, mas perto de trezentos, que o compraram entre todos ${ }^{414}$.

ZEUS - Levem-no e apresentemos outro.

7. HERMES - Queres aquele ali todo encardido o do Ponto? 415

ZEUS - Sim, precisamente.

HERMES - Tu aí, o do alforge a tiracolo, o de ombro descoberto ${ }^{416}$, chega-te aqui e dá uma volta pela sala... Ponho à venda um modelo de vida viril, um modelo excelente e corajoso, um modelo livre... Quem quer comprar?

COMPRADOR - Ó leiloeiro, que é que estás a dizer? Estás a pôr à venda quem é livre?

HERMES - Estou, pois.

COMPRADOR — E não receias ele te mova um processo por escravização de pessoa livre ${ }^{417}$ e que te cite perante o Areópago?

simultaneamente, um nome e uma fava; se esta era branca, a pessoa cujo nome havia sido tirado era eleita; caso a fava fosse preta, não era eleito.

$4131 \mathrm{mina}=100 \mathrm{dracmas}$, pelo que o MODELO PITAGÓRICO custa ao comprador a quantia, nem muito alta nem muito baixa, de 1000 dracmas. Mais adiante, o MODELO ACADÉMICO será vendido por dois talentos = 120 minas, ou seja, doze vezes mais caro.

${ }^{414}$ Referência à confraria fundada por Pitágoras no sul da Itália (Magna Grécia), depois de este ter sido exilado de Samos pelo tirano Polícrates.

415 Trata-se de Diógenes de Sinope (Capadócia e região do Ponto Euxino), o mais célebre dos filósofos cínicos.

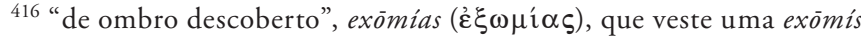
( $\dot{\xi} \omega \mu$ íৎ), que era uma túnica curta, de escravo ou também (significativamente!) usada pelos filósofos cínicos, que deixava o ombro direito descoberto.

417 "escravização de pessoa livre", mais propriamente "rapto e venda, como escravo, de uma pessoa livre, gr. andrapodismós ( $\alpha \vee \delta \rho \alpha \pi \circ \delta \imath \sigma \mu o ́ \varsigma)$. 
HERMES - Ele não se importa com ser vendido, pois pensa que, de uma maneira ou doutra, é livre.

COMPRADOR - Mas para que é que alguém quereria utilizar um tipo todo encardido e de aspecto miserável, a não ser para fazer dele um cavador ou um aguadeiro?

HERMES - Não só isso, mas também o empregarás como porteiro, pois terás nele o mais fiel dos cães. De resto, ele já é cáo de seu nome. ${ }^{418}$

COMPRADOR - Donde é que ele é que tipo de vida é que ele preconiza?

HERMES - Pergunta-lhe tu mesmo, pois é melhor assim.

COMPRADOR - Tenho medo do seu aspecto sombrio e macambúzio, que ele me ladre ao ver-me aproximar-me, ou mesmo, por Zeus!, que me morda. Não estás vendo como tem o cajado alçado, as sobrancelhas franzidas e lança olhares ameaçadores e coléricos.

HERMES - Não tenhas medo, que ele está domesticado.

8. COMPRADOR - Antes de mais, meu caro, donde és tu? MODELO CÍNICO ${ }^{419}$ — De toda a parte.

COMPRADOR - Como é isso?

MODELO CÍNICO — Estás a olhar para um cidadão do mundo. ${ }^{420}$

COMPRADOR - Quem é que tu imitas?

MODELO CÍNICO - Héracles.

COMPRADOR - Então porque é que não envergas a pele de leáo? Realmente, pelo cajado já te pareces com ele.

MODELO CÍNICO - A minha pele de leão é a minha túnica ${ }^{421}$. Tal como Héracles, faço a guerra aos prazeres, não por mo ordenarem, mas por minha própria vontade, no propósito de purificar a vida [humana].

418 Os filósofos cínicos (künikoí: кvvıкoí) consideravam autênticos “cães” (küōn, tema kün-), animal pelo qual também juravam.

419 Junto uma nota idêntica à referente a MODELO PITAGÓRICO: Os manuscritos têm DIÓGENES, o que causaria certa dificuldade, pois não se trata de vender esse e outros filósofos, mas sim o seu modelo de vida. Em todo o caso, a resposta do "MODELO" contém elementos da vida do filósofo Diógenes.

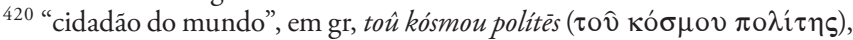
donde dizemos, em port., cosmopolita.

${ }^{421} \mathrm{O}$ vocábulo tribónion ( $\tau \rho \imath \beta \omega ́ v ı$ ov) significa "manto curto", de lã grosseira, usado pelos escravos, gente pobre e... certos filósofos... 
COMPRADOR — Que belo propósito... que é que diremos que tu conheces bem? Qual é o teu ofício?

MODELO CÍNICO - Sou libertador dos homens e médico das suas paixóes. Em resumo, pretendo ser profeta da verdade e da livre expressão.

9. COMPRADOR - Muito bem, ó profeta... Mas, se eu te comprar, de que modo é que me exercitarás?

MODELO CÍNICO - Em primeiro lugar, pego em ti, dispo-te do teu luxo, reduzo-te à indigência e visto-te um manto curto, após o que te obrigarei a penar e a trabalhar, a dormir no chão, a beber [somente] água, a matar a fome com o que calhar; quanto ao dinheiro, se o possuíres, segue o meu conselho e lança-o ao mar; não te preocuparás nem com casamento, nem com filhos, nem com pátria, coisas que, todas elas, considerarás como grandes tolices; tendo deixado a casa paterna, habitarás num túmulo, numa torre abandonada ou num tonel. O teu alforge estará cheio de tremoços e de rolos escritos em ambas as faces. Vivendo desta maneira, bem poderás dizer que és mais feliz que o Grande Rei ${ }^{422}$. E mesmo que te chicoteiem ou te torturem, náo considerarás nada disso como doloroso.

COMPRADOR - Como podes tu afirmar uma coisa dessas, ou seja, que eu estou a ser chicoteado e não tenho dores? $\mathrm{Na}$ verdade, a minha pele náo tem uma carapaça de tartaruga ou de caranguejo.

MODELO CÍNICO - Seguirás o dito de Eurípides, com uma pequena alteração.

\section{COMPRADOR - Qual dito? MODELO CÍNICO -}

\section{Minha alma sofrerá dor, | mas a lingua é insensivel. ${ }^{423}$}

10. As principais qualidades que deves adquirir são as seguintes: tens de ser descarado, insolente e injurioso para toda a gente sem excepção, quer se trate de reis, quer de pessoas comuns, pois deste modo háo-de repara em ti e considerar-te como um tipo corajoso. Que a tua linguagem seja bárbara, a tua voz desafinada

422 O “grande Rei” é Creso, fabuloso e faustuoso rei da Pérsia.

${ }^{423} \mathrm{O}$ verso de Eurípides (Hipólito, 612) opôe também a alma à língua, mas de maneira oposta: A lingua fez juramento, | a alma nada jurou. 
e decididamente parecida com o ladrar de um cáo; que o teu rosto se apresente carrancudo, e o teu modo de andar condizente com o teu rosto, numa palavra, que tudo em ti seja selvagem e rude. Que [coisas como] o pudor, a decência e a moderação estejam bem longe de ti; apaga do teu rosto todo e qualquer vestígio de vermelhidáo; procura os locais mais concorridos de gente e, nesses locais, faz por ficar sozinho e sem qualquer companhia, sem te aproximares nem de um amigo nem de um estrangeiro, pois essas relaçóes são o fim do teu império; atreve-te a fazer, à vista de toda a gente, o que ninguém faria sequer em privado; em matéria de sexo, assume as formas mais cómicas; finalmente, quando te parecer, suicida-te, comendo um polvo cru ou um calamar ${ }^{424}$. É esta a felicidade que te prometemos.

11. COMPRADOR - Raios te partam! O que estás a dizer é vergonhoso e indigno de um homem.

MODELO CÍNICO - Mas pelo menos, meu caro, são coisas muito fáceis e cómodas de pôr em prática por qualquer um. De facto, não necessitarás de instrução, de exposições [magistrais] ou outras patetices, mas, pelo contrário, é bastante curta esta minha via de acesso à glória. Mesmo que sejas uma pessoa vulgar, por exemplo, um sapateiro, um salsicheiro, um carpinteiro ou um publicano ${ }^{425}$, nada te impede de vires a ser muito admirado, desde que possuas descaramento e atrevimento e aprendas muito bem a insultar.

COMPRADOR - Para essas ocupaçóes náo preciso de ti, mas, em caso de necessidade, talvez pudesses fazer de marinheiro, ou de jardineiro ${ }^{426} .$. isto se aqui o pregoeiro consentir em vender-te por, no máximo, dois óbolos ${ }^{427}$.

HERMES - Pois fica com ele. Na verdade, é até com grande satisfação que nos veremos livres dele, pois incomoda-nos,

${ }^{424}$ Sobre a morte de Diógenes, existiam na Antiguidade diversas versóes...

425 Os publicanos eram cobradores (arrematadores) de impostos, que pagavam ao Estado uma certa quantia, para terem o direito de cobrar, para si próprios, os impostos devidos pelos cidadáos. Imagina-se o "zelo" com que o faziam, bem como o ódio que suscitavam.

426 "jardineiro" ou "horteláo".

4272 óbolos constituem uma oferta miserável e humilhante. Recorde-se que o MODELO PITAGÓRICO foi vendido por 10 minas = $1000 \mathrm{dracmas}$ $=6000$ (seis mil) óbolos, ou seja, por um valor 3000 vezes superior! Deve, no entanto, dizer-se que Luciano tinha um conceito elevado dos filósofos cínicos, que até são como que seus "representantes" em diversas obras... 
grita, insulta-nos a todos sem excepção e usa uma linguagem imprópria.

12. ZEUS - Chama outro... o Cirenaico ${ }^{428}$, o do manto de púrpura e com uma coroa de flores [na cabeça].

HERMES - Atenção a todos! Trata-se de um artigo de luxo, que requer um comprador rico. É um modelo de vida extremamente delicioso, três vezes feliz. Quem deseja a volúpia? Quem compra esta coisa táo delicada?

COMPRADOR - Tu, chega aqui e diz-me que conhecimentos é que tens, pois só te compro, se tiveres alguma utilidade.

HERMES - Não o incomodes, meu caro, não o interrogues, que o tipo está bêbado, pelo que não seria capaz de te responder, pois, como vês, tem a língua entaramelada.

COMPRADOR - Quem é que, no seu perfeito juízo, compraria um escravo tão corrupto e tão depravado? Como tresanda a perfume! E como tem um andar incerto e cambaleante! Mas mesmo assim, ó Hermes, diz-me tu que qualidades é que ele possui e qual o seu objectivo de vida.

HERMES - Em termos gerais, é um especialista em convivência, um bom companheiro de bebida, a pessoa indicada para farrar com uma tocadora de flauta na companhia de um patrão sensual e debochado. Além disso, é um [autêntico] sábio em doçaria, um cozinheiro muito experiente, enfim... um mestre de voluptuosidade. Foi educado em Atenas, prestou serviço na corte dos tiranos da Sićlia, tendo sido muito gabado por eles. O cerne da sua doutrina consiste em desprezar todas as coisas, mas servir-se de todas elas, e de todas retirar prazer.

COMPRADOR - Trata de descobrir por aí outro comprador, mas dos ricos e endinheirados, pois eu náo estou em condiçóes de comprar uma vida de diversão.

HERMES - Ó Zeus, parece que este vai ficar por vender.

13. ZEUS - Leva-o daqui e traz outro... ou melhor, aí esses dois, o risonho de Abdera ${ }^{429}$ e o chorão de Éfeso, pois pretendo vendê-los em conjunto.

${ }^{428}$ Referência à Escola Cirenaica, fundada por Aristipo, que fora discípulo de Sócrates. Fazia do prazer o sumo bem da vida, embora distinguisse entre prazeres bons e prazeres causadores de males.

429 "o risonho de Abdera e o chorão de Éfeso são, respectivamente, Demócrito e Heraclito. 
HERMES - Cheguem aqui, vocês os dois... [Apregoa] Vendo dois modelos de vida, ponho em leilão os dois mais sábios de todos.

COMPRADOR - Ó Zeus! Que contraste! Um não cessa de rir, o outro parece estar a carpir um morto, num choro contínuo... Tu aí, que é lá isso? Porque está a rir?

MODELO DEMOCRÍTICO ${ }^{430}$ — Ainda perguntas? É que todas as cousas que vós fazeis me parecem ridículas, assim como as vossas próprias pessoas.

COMPRADOR - Que é que estás a dizer? Que te ris de nós todos e que não dás a mínima importância às nossas coisas?

MODELO DEMOCRÍTICO - Isso mesmo. Não há nada de sério nessas vossas cousas, tudo é vazio, movimento de átomos e o infinito ${ }^{431}$.

COMPRADOR - Nada disso, tu é que és verdadeiramente vazio e ignorante ${ }^{432}$. Mas que insolência! Não páras de rir?...

14. ... E tu aí, meu caro, porque estás a chorar? Na verdade, julgo que é melhor falar contigo.

MODELO HERACLÍTICO - É que eu, ó estrangeiro, considero as coisas humanas deploráveis e dignas de dó, não havendo nenhuma delas que não seja perecível. Tenho mesmo pena dos homens e lastimo-os, e creio que as coisas presentes não são lá grande coisa, e, quanto às do tempo futuro, elas serão completamente aflitivas, quero eu dizer, a conflagração e a destruição do Universo. Lastimo tudo isso, e ainda o facto de nada ser estável, mas tudo se misturar como num caldo, sendo

${ }^{430}$ À semelhança dos casos precedentes, verto por "MODELO DEMOCRÍTICO", mas o texto sugere fortemente a pessoa de Demócrito, bem como, a seguir, a pessoa de Heraclito. As falas de ambos os MODELOS são em dialecto jónico, impossível de verter com alguma verosimilhança.

431 Segundo os atomistas, o mundo físico reduz-se a duas realidades: o cheio e o vazio, ou seja, os átomos e o local onde eles se movem; o movimento aleatório dos átomos produzam todas as combinaçóes do mundo material; alude-se também aos universos infinitos...

432 "vazio e ignorante": O comprador entende estes dois adjectivos, não no sentido científico dado por Demócrito, mas no sentido comum; acrescente-se o último, ápeiros (’’ $\pi \varepsilon \iota \rho \circ \varsigma)$ refere-se a duas palavras completamente distintas, em que o $2^{\circ}$ elemento é, num caso, peîrar ( $\pi \varepsilon \hat{\imath} \rho \alpha \rho$ ) "termo", "extremidade", e, no outro caso, peîra ( $\pi \varepsilon \hat{\imath} \rho \alpha)$ "experiência", "saber vindo da experiência". Para mantermos, de algum modo, o jogo de palavras, verteríamos (abusivamente, é claro) por "vazio e infinitamente ignorante" 
uma e a mesma coisa o prazer e a dor, o saber e a ignorância, o grande e o pequeno, com todas as coisas a mover-se para cima e para baixo e a transmutarem-se neste jogo da eternidade ${ }^{433}$.

COMPRADOR - Mas então que vem a ser a eternidade? MODELO HERACLÍTICO — É um menino a brincar, a jogar aos dados, ora lançando-os, ora recolhendo-os ${ }^{434}$.

COMPRADOR - E que é o homem?

MODELO HERACLÍTICO - Deuses mortais.

COMPRADOR - E os deuses?

MODELO HERACLÍTICO - Homens imortais.

COMPRADOR - Estás a falas por enigmas, meu caro, ou a inventar jogos de palavras? De facto, tal como [Apolo] Lóxias, não te exprimes nada claramente.

MODELO HERACLÍTICO - Não me preocupo nada convosco.

COMPRADOR - Por isso, não haverá ninguém que, no seu perfeito juízo, te compre.

MODELO HERACLITICO - Pois eu incito-vos a todos, sem distinçáo de idade, tanto aos que querem como aos que não querem comprar-me, a que choreis.

COMPRADOR - Esta sua doença náo anda muito longe do humor negro ${ }^{435}$. Como quer que seja, eu cá por mim não comprarei nenhum deles.

HERMES — Também estes vão ficar por vender.

ZEUS - Anuncia outro.

15. HERMES - Queres ali aquele ateniense, o tagarela? ZEUS - Sim, claro.

HERMES - Tu, chega aqui... Pomos em leilão um modelo de vida excelso e inteligente. Quem quer comprar um modelo de santidade?

COMPRADOR — Ora diz-me cá: Que é que tu sabes a fundo?

433 "eternidade" (aiốn: $\alpha i \omega ́ v)$ é um dos diversos sentidos, talvez aquele que lhe foi atribuído por Heraclito. A "definição" que vem a seguir é mesmo própria do Heraclito que já os antigos classificavam de skoteinós

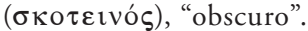

434 "ora lançando-os, ora recolhendo-os", é como interpreto os particípios médios diapherómenos e sümpherómenos ( $\delta 1 \alpha \varphi \varepsilon \rho o ́ \mu \varepsilon v o \varsigma . . . \sigma v \mu \varphi \varepsilon \rho o ́-$ $\mu \varepsilon v o \varsigma)$. Os diversos tradutores traduzem (interpretam!) diversamente...

435 "humor negro": A palavra grega é melankholía ( $\mu \varepsilon \lambda \alpha \gamma \chi 0 \lambda i ́ \alpha)$, lit. te "bílis negra", que, segundo a teoria dos humores, produzia indivíduos sorumbáticos, neurasténicos e cheios de azedume. 
MODELO ACADÉMICO ${ }^{436}$ - Amo os rapazinhos ${ }^{437}$ e sou especialista em coisas de amor.

COMPRADOR - Como haveria eu de te comprar? $\mathrm{Na}$ verdade, do que eu precisava era de um pedagogo ${ }^{438}$ para o meu filho, que é um belo rapaz.

MODELO ACADÉMICO - E quem haveria melhor do que eu, para conviver com um belo rapaz? $\mathrm{Na}$ verdade, eu não estou apaixonado pelos corpos, pois considero que a alma é que é bela. Não te dê cuidado, pois mesmo que eles se deitem sob o mesmo manto que eu, de todos ouvirás dizer que não sofreram qualquer dano da minha parte.

COMPRADOR - É incrível isso que estás a dizer, [ou seja,] que um homem que ama rapazes não se preocupa senão com a alma, quando tem toda a liberdade, assim deitado sob o mesmo manto.

16. MODELO ACADÉMICO - E no entanto, juro-te pelo cão e pelo plátano ${ }^{439}$ que é assim mesmo.

COMPRADOR - Por Héracles! Que estranheza de deuses! MODELO ACADÉMICO - Que é que estás a dizer? Não achas que o cão é um deus? Então não vês o Anúbis no Egipto, como é tăo importante, e Sírio no céu, e Cérbero no reino subterrâneo?

17. COMPRADOR - Dizes bem, eu é que esta equivocado... Mas qual é o teu modo de vida?

MODELO ACADÉMICO ${ }^{440}-$ Habito numa cidade que eu próprio construí, tenho uma constituição completamente nova e governo-me por leis próprias.

${ }^{436} \mathrm{O}$ filósofo que está por detrás deste modelo é, sobretudo, Sócrates, mas também Platão. Poderíamos apresentar o MODELO SOCRÁTICO.

437 "Amo os rapazinhos": O termo grego é paiderastés ( $\left.\pi \alpha \_\delta \varepsilon \rho \alpha \sigma \tau \eta \dot{\varsigma}\right)$ ), que pode ter o sentido "mais puro" (v. texto a seguir), mas que também já podia ter o sentido moderno, não de pederasta, mas de pedófilo.

${ }^{438} \mathrm{O}$ pedagogo, como a etimologia indica (paid-agōgós: $\pi \alpha 1 \delta$ - $\alpha \gamma \omega \gamma$ ${ }^{\circ} \varsigma$ ) era o escravo que acompanhava o menino à escola; é claro que, sobretudo na época romana, os grandes senhores contratavam pedagogos cultos (sobretudo gregos), que eram autênticos professores particulares.

439 "pelo cáo e pelo plátano" eram juramentos realmente estranhos, mas usados por Sócrates (e mais tarde, naturalmente, pelos cínicos).

${ }^{440}$ Enquanto, acima, o Modelo Académico se referia sobretudo a Sócrates, aqui alude-se claramente à República de Platáo e à sua cidade ideal. 
COMPRADOR - Gostaria de te ouvir [enunciar] um só artigo.

MODELO ACADÉMICO - Ora ouve lá aquele que me parece o mais importante, a respeito das mulheres: nenhuma delas pertence a um homem em exclusivo, mas cada uma pode ter relaçóes com qualquer um que assim o deseje.

COMPRADOR - Queres tu dizer que ficam abolidas as leis a respeito do adultério?

MODELO ACADÉMICO — Sim, por Zeus!, bem como, simplesmente, todas as ninharias sobre essa matéria.

COMPRADOR - E que é que decidiste a respeito dos jovens formosos?

MODELO ACADÉMICO — Esses constituirão, com seus beijos, um prémio para os melhores, aqueles que tenham cometido algum feito brilhante ou valoroso.

18. COMPRADOR — Oh! Que belo presente!... Mas agora... qual é o ponto essencial da tua sabedoria?

MODELO ACADÉMICO - As Ideias e os modelos das coisas que existem. Na verdade, tudo o que tu vês - a terra, o que há sobre a terra, o céu, o mar... - ... de todas essas coisas existem imagens invisíveis fora do Universo.

COMPRADOR - E em que lugar é que elas existem?

MODELO ACADÉMICO - Em parte nenhuma, porquanto, se estivessem em alguma parte, náo existiriam.

COMPRADOR - Mas eu não vejo esses tais modelos a que te referes...

MODELO ACADÉMICO - Pois claro que não, pois tu és cego no que toca aos olhos da alma. Eu, porém, vejo as Imagens de tudo, [por exemplo,] um "tu” invisível, ou um outro "eu", em suma, vejo todas as coisas a dobrar.

COMPRADOR - Nesse caso, tenho de te comprar, sábio como és e tão penetrante de vista... Vejamos, que preço é que me fazes por este?

HERMES - Dá cá dois talentos ${ }^{441}$.

COMPRADOR - Está comprado por esse preço... mas pagar-te-ei mais tarde.

${ }^{441} 1$ talento $=60$ minas. Recorde-se que $(\$ 6)$ o MODELO PITAGÓRICO foi vendido por 10 minas. Portanto, 2 talentos $=120$ minas, o que significa que o MODELO ACADÉMICO valeu doze vezes mais que o MODELO PITAGÓRICO. É um valor altíssimo... 
19. HERMES - Diz-me o teu nome.

COMPRADOR - Díon de Siracusa ${ }^{442}$.

HERMES - Vamos, leva-o... e boa sorte. Agora chamo-te a ti, o Modelo Epicurista... Quem quer comprá-lo? É discípulo daquele que ria muito, e também do bêbado ${ }^{443}$, os quais ainda agora apregoámos. No entanto, num coisa é superior a estes, pelo facto de ser mais ímpio. Quanto ao resto, é um tipo agradável e amigo da boa mesa.

COMPRADOR - Qual é o preço?

HERMES - Duas minas ${ }^{444}$.

COMPRADOR - Toma lá... Mas este tipo... é só para saber... que acepipes é que ele aprecia?

HERMES - Os que são doces, feitos à base de mel e sobretudo passas de figo.

COMPRADOR - Não tem problema, havemos de lhe comprar bolinhos de passas da Cária.

20. ZEUS - Chama outro... esse aí, o da cabeça rapada, esse trombudo, o do Pórtico ${ }^{445}$.

HERMES - Dizes bem. Realmente, parece que está à espera dele uma grande multidáo de pessoas que acorreram ao leilão ${ }^{446}$... Ponho à venda a própria virtude, a mais perfeita das vidas... Quem quer ser a única pessoa que conhece todas as coisas?

COMPRADOR — Porque dizes isso?

HERMES - Porque este é o único que é sábio, o único que é belo, o único justo, corajoso, rei, orador, rico, legislador, e todas as outras virtudes.

COMPRADOR — Portanto, é o único que é cozinheiro e, por Zeus!, curtidor, carpinteiro e por aí fora?

HERMES - Assim parece.

${ }^{442}$ Amigo e discípulo de Platão.

${ }^{443}$ Referência, respectivamente, ao Modelo Democrítico (v. \$13) e ao Modelo Cirenaico (v. $\$ 12$, nota a "Cirenaico") e ao fundador da Escola Cirenaica, Aristipo.

${ }^{444} 1$ talento = 60 minas; portanto, o Modelo Epicurista ( 2 minas $)$ vale 60 vezes menos que o Modelo Académico (2 talentos).

${ }^{445}$ Os filósofos estóicos também eram designados por “os do Pórtico". o Pórtico era, em Atenas, uma galeria ornamentada com pinturas, onde funcionava a escola que teve por mestres Zenão, Crisipo...

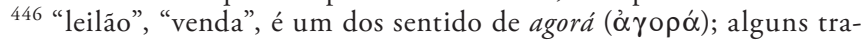
duzem por "... que frequentam a praça pública”: não me parece... 
21. COMPRADOR - Chega cá, meu caro, e diz a este teu [futuro] comprador quem és tu, mas, em primeiro lugar, se náo te sentes incomodado por seres vendido e ficares na condição de escravo.

MODELO ESTÓICO ${ }^{447}$ - De maneira nenhuma, uma vez que essas coisas não dependem de nós, e as coisas que não dependem de nós são naturalmente indiferentes ${ }^{448}$.

COMPRADOR - Não percebo o que queres dizer com isso [de indiferentes].

MODELO ESTÓICO — Que estás a dizer? Não percebes que, entre estas, umas são preferiveis ${ }^{449}$, ao passo que outras são não-preferiveis?

COMPRADOR - Também não percebo.

MODELO ESTÓICO - É natural, pois não estás familiarizado com a nossa terminologia nem possuis a imaginação compreensiva, ao passo que o estudioso diligente, aquele que aprendeu a teoria lógica, não só conhece essa terminologia, mas também o que são o acidente e o sub-acidente ${ }^{450}$, e em que é que diferem um do outro.

COMPRADOR - Pela Sabedoria! Tem a bondade de me explicar essa coisa, que é o acidente e que é o sub-acidente. $\mathrm{Na}$ verdade, não sei lá como, fiquei impressionado com a cadência fónica desses termos.

MODELO ESTÓICO - Com todo o gosto. Por exemplo, se um coxo bater numa pedra com o seu pé coxo e com isso ficar com um ferimento, ele, que já antes tinha um acidente pelo facto de ser coxo, recebeu, além disso, um ferimento, que é um sub-acidente.

${ }^{447}$ Os manuscritos têm CRISIPO, Este (280-207 a.C.) foi um dos chefes do Estoicismo e seu grande teorizador (232-207 a.C.). O Estoicismo gozou de grande fama em toda a Antiguidade, pela sua austeridade e por uma moral irrepreensível.

${ }^{448}$ O Modelo Estóico utiliza um vocabulário muito técnico e de sentido filosófico mais ou menos esotérico, inacessível para os não iniciados, pois essa terminologia era objecto de análise profunda feita pelo Mestre. Limito-me a indicar esses termos em itálico.

449 "preferiveis ... não-preferiveis"; entre estas últimas (não dependentes da nossa vontade, portanto indiferentes, mas também não-preferiveis), contam-se, p. ex., a doença, a pobreza...

450 "acidente e sub-acidente", ou "predicamento e sub-predicamento", termos referidos à situação do sujeito relativamente à acção, uma das quais é "primária”, à qual se acrescenta outra, "secundária”. V. a explicaçáo dada pelo Mestre logo a seguir. 
22. COMPRADOR — Mas que subtileza! E que mais coisas é que afirmas saber?

MODELO ESTÓICO - Umas teias de palavras, com as quais enredo os meus interlocutores, lhes tapo a boca e os obrigo a calarem-se, aplicando-lhes firmemente uma mordaça. O nome desta poderosa arma é o famoso silogismo.

COMPRADOR - Por Héracles!, falas de uma coisa imbatível e muito violenta.

MODELO ESTÓICO — Ora vê lá: Tu tens um filho?

COMPRADOR - Que é que isso tem?

MODELO ESTÓICO — Se um crocodilo raptar o menino, que encontrou vagueando na margem do rio, e depois prometer devolver-to, desde que tu lhe digas, com verdade, se ele tem a intenção de realmente te devolver a criança, que é que achas que o crocodilo decidirá?

COMPRADOR - Fazes-me uma pergunta de difícil resposta. Na verdade, hesito sobre qual das duas resposta devo dar, a fim de recuperar [o meu filho]. Mas, por Zeus!, responde por mim e salva o meu menino, antes que o crocodilo o devore.

MODELO ESTÓICO - Fica tranquilo. Hei-de ensinar-te outras coisas ainda mais admiráveis.

COMPRADOR - Que coisas?

MODELO ESTÓICO - O do ceifeiro, o do dominante, e sobretudo o da Electra e o do encoberto.

COMPRADOR - Que queres dizer com isso do encoberto ou da Electra?

MODELO ESTÓICO - Trata-se da famosa Electra, filha de Agamémnon, que sabe e ao mesmo tempo não sabe uma determinada coisa. De facto, quando Orestes, ainda incógnito, aparece à sua frente, ela sabe que Orestes é seu irmão, mas ignora que aquele [jovem] é Orestes. Quanto ao encoberto, vais ouvir um raciocínio muitíssimo admirável. Ora responde-me: Conheces o teu próprio pai?

COMPRADOR - Sim.

MODELO ESTÓICO — Então, se eu pusesse à tua frente alguém de cara coberta e te perguntasse "Conheces este homem?", que é que responderias?

COMPRADOR - Claro que não o conheço. 
23. MODELO ESTÓICO - E no entanto, esse homem era o teu pai. Portanto, se náo o conheces, é óbvio que não conheces o teu pai.

COMPRADOR — Nada disso, pois, ao destapá-lo, saberei a verdade... Mas agora... qual é o objectivo da tua sabedoria? Que é que farás, depois de alcançares o cume da Virtude?451

MODELO ESTÓICO - Possuirei os primeiros bens da natureza, ou seja, a riqueza, a saúde e coisas desse género. Antes, porém, tenho de penar bastante, passando os olhos por rolos de escrita miudinha, coleccionando comentários, enchendo-me de solecismos e de palavras bizarras e - o principal de tudo — não é possível [a um homem] tornar-se sábio, se não tomar eléboro ${ }^{452}$ três vezes seguidas.

COMPRADOR - Tudo isso são princípios nobres e sumamente corajosos... Mas... que diremos do facto de tu seres um Gnífon $^{453}$ e um agiota?... Sim, vejo que tens também esta faceta... Será isto próprio de um homem que já bebeu eléboro e de perfeita virtude?

MODELO ESTÓICO - Mas sim! Na verdade, ao sábio, e só a ele, é permitido emprestar dinheiro a juros, pois o seu próprio domínio consiste em silogizar ${ }^{454}$; ora, emprestar dinheiro e calcular ${ }^{455}$ os juros anda muito perto, julgo eu, de silogizar, e quer uma actividade, quer outra, são próprias do sábio, o facto de vencer juros, náo apenas simples, como [faz] a maioria, mas segundos juros derivados dos primeiros. Ou será que desconheces que, no que respeita a juros, uns são "primeiros" outros são "segundos", como que uma espécie de "derivados" daqueles? Vês nisto um silogismo, que diz assim: "Se uma pessoa receber $o$ primeiro juro, recebe também o segundo; ora, essa pessoa receberá o primeiro; logo, receberá também o segundo."

${ }^{451}$ Imagina-se que a Virtude se encontra no alto de uma montanha escarpada, só alcançável após muito estudo e penosíssimos trabalhos e sofrimentos.

452 eléboro ou heléboro, planta utilizada pelos antigos no tratamento de doenças nervosas e do foro psíquico em geral, particularmente da loucura. Precisamente Crisipo tratou a sua doença por três vezes...

453 Gnífon, como nome comum, significa "avarento”...

454 "silogizar" existe em português... e corresponde perfeitamente ao gr. süllogizesthai ( $\sigma v \lambda \lambda \circ \gamma \hat{\imath} \zeta \varepsilon \sigma \theta \alpha \imath)$, que, aliás, ocorre em latim: syllogizare. 455 "calcular", gr. logizesthai $(\lambda \circ \gamma i \zeta \varepsilon \sigma \theta \alpha \mathrm{l})$ e "silogizar" süllogizesthai ( $\left.\sigma \cup \lambda \lambda \operatorname{o\gamma }^{\prime} \zeta \varepsilon \sigma \theta \alpha \imath\right)$ têm muito em comum... como se vê... 
24. COMPRADOR - Será que podemos dizer o mesmo dos honorários que, pela tua sabedoria, recebes dos jovens, e que é óbvio que somente o sábio receberá honorários pela sua virtude?

MODELO ESTÓICO - Acertaste. Na verdade, porém, eu faço-me pagar, não por mim próprio, mas para benefício do pagante. De facto, existe, por um lado, o pagador, e, por outro lado, o cobrador. Eu exerço a função de receptor, e o meu discípulo a de pagador.

COMPRADOR - No entanto, devia passar-se o contrário: o jovem ser receptor, e tu, o único que é rico, seres pagador.

MODELO ESTÓICO - Estás a troçar de mim, meu caro. Mas tem cuidado, não dispare contra ti um silogismo indemonstrável.

COMPRADOR - E que mal me viria da "frechada"?

MODELO ESTÓICO — A perplexidade, o silêncio e o espírito revirado...

25.... E o pior de tudo, se eu quiser, transformo-te em pedra.

COMPRADOR - Em pedra, como? Meu caro, não me pareces ser um [outro] Perseu.

MODELO ESTÓICO - Desta maneira: A pedra é [ou não é] um corpo?

MODELO ESTÓICO - E então? O animal não é [também] um corpo?

COMPRADOR - É.

MODELO ESTÓICO - E tu, és [ou não és] um animal? COMPRADOR - Assim parece.

MODELO ESTÓICO — Portanto, se és um corpo, és uma pedra.

COMPRADOR - De maneira nenhuma! Mas agora, por Zeus!, transforma-me em sentido inverso e torna-me novamente homem.

MODELO ESTÓICO — Não é nada difícil. Pois que sejas de novo homem. Ora diz-me: Todo o corpo é um animal?

COMPRADOR - Não.

MODELO ESTÓICO — Pois bem. E uma pedra é um animal?

COMPRADOR - Não.

MODELO ESTÓICO — E tu és um corpo?

COMPRADOR - Sim. 
MODELO ESTÓICO — E sendo tu um corpo, és [também] um animal?

COMPRADOR - Sim.

MODELO ESTÓICO - Portanto, não és uma pedra, visto que és um animal.

COMPRADOR - Saíste-te muito bem, pois as minhas pernas já começavam a ficar geladas e rígidas, como as de Níobe ${ }^{456}$. Em todo o caso, vou comprar-te. Quanto é que tenho de desembolsar por ele?

HERMES - Doze minas.

COMPRADOR - Toma lá.

HERMES - Foste tu sozinho a comprá-lo?

COMPRADOR - Não, por Zeus!, mas aqui estes todos que estás vendo.

HERMES - São de facto muitos, de ombros fortes e merecedores do [silogismo do] ceifeiro.

26. ZEUS - Não percas tempo. Chama outro... o Peripatético.

HERMES - É contigo que estou a falar, o belo, o ricaço... [Aos compradores] Vamos, comprem o mais inteligente de todos, o que sabe absolutamente tudo.

COMPRADOR - Que espécie de tipo é ele?

HERMES - É moderado, tem bom feitio, bem adaptado ao seu modo de vida e - o mais importante de tudo - [um tipo] duplo.

COMPRADOR - Como é isso?

HERMES - Por fora, aparece como uma [determinada] pessoa, mas por dentro parece outra. Portanto, se o comprares, lembra-te de tratá-lo ora por exotérico, ora por esotérico ${ }^{457}$.

COMPRADOR - E que é que ele sabe a fundo?

HERMES - Que são três os bens: os da alma, os do corpo, e os do mundo exterior.

COMPRADOR - Tem sentimentos humanos. Quanto custa?

HERMES - Vinte minas.

COMPRADOR - É muito caro.

HERMES - Não é, não, meu caro, pois ele parece possuir algum dinheiro. Por isso, não percas tempo a comprá-lo. Além disso, logo aprenderás com ele quanto tempo vive um mosquito,

456 Níobe, filha de Tântalo, foi transformada em rocha...

457 "exotérico" e esotérico, termos referentes a duas teorias de Aristóteles. 
até que profundidade é que o mar recebe a luz do sol, e qual a natureza da alma das ostras.

COMPRADOR - Por Héracles, que precisão de ciência!

HERMES - E o que não seria, se o ouvisses dissertar sobre coisas muito mais subtis, a respeito do esperma e da fecundação, da formação do embrião no útero, como o homem é um ser caricato e o burro não é um ser caricato, que não constrói casas nem viaja em navios?

COMPRADOR - Ora aí estão ensinamentos muitíssimo respeitáveis e utilíssimos; portanto, compro-o por vinte minas.

HERMES - Seja.

ZEUS - Quem é que nos resta?

HERMES — Resta aqui este céptico... Tu aí, "Ruivinho”458, avança, que é para seres posto em leilão a toda a velocidade, pois a maior parte das pessoas já vai saindo, e o leilão vai fazer-se com pouca gente. Mesmo assim, quem quer comprar este?

COMPRADOR - Quero eu, mas primeiro diz-me cá: Que é que tu sabes?

MODELO CÉPTICO — Nada.

COMPRADOR - Que é que queres dizer com isso?

MODELO CÉPTICO - Que, em minha opinião, não existe absolutamente nada.

COMPRADOR - Quer dizer que nós não existimos?

MODELO CÉPTICO — Nem mesmo isso eu sei.

COMPRADOR - Nem sequer tu existes?

MODELO CÉPTICO - Isso é o que eu mais ignoro.

COMPRADOR - Mas que coisa tão complicada! E que querem dizer estes pesos?

MODELO CÉPTICO - Com eles peso os argumentos e acerto-os até [ficarem] ao mesmo nível. E assim que vejo que eles são exactamente iguais e têm o mesmo peso, então... então sim: fico sem saber qual é o [argumento] mais verdadeiro.

COMPRADOR — E que mais é que sabes fazer na perfeição? MODELO CÉPTICO - Tudo, excepto perseguir um escravo fugitivo ${ }^{459}$.

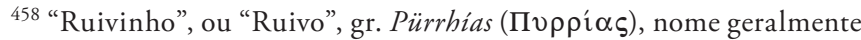
aplicado a escravos da Trácia, que eram "ruivos". Aqui, porém, há um jogo de palavras intraduzível, uma alusão ao nome Pürrhōn (Пv́ $\rho \omega v)$, "Pírron", fundador da Escola Céptica.

459 "escravo fugitivo": o texto não explicita, mas esse escravo fugitivo (e inalcançável!) é a verdade. Aliás — lê-se um pouco adiante — o objectivo 
COMPRADOR - E porque é que isso te é impossível?

MODELO CÉPTICO — Porque, meu caro, não consigo apanhá-lo.

COMPRADOR - Claro que não, lento e lerdo como pareces ser... Mas então qual é o objectivo da tua ciência?

MODELO CÉPTICO — A ignorância e também não ouvir nem ver.

COMPRADOR - Queres tu dizer que és ao mesmo tempo cego e surdo?

MODELO CÉPTICO - E além disso desprovido de opiniáo e completamente estúpido... em suma: em nada diferente de um verme.

COMPRADOR — Por isso mesmo é que quero comprar-te... Quanto é que queres por ele?

HERMES - Uma mina ática.

COMPRADOR - Toma lá... E tu, que é que dizes? Achas que eu te comprei?

MODELO CÉPTICO - Duvido.

COMPRADOR — Mas não! A verdade é que eu te comprei e desembolsei o dinheiro.

MODELO CÉPTICO - Suspendo [o julgamento] ${ }^{460}$ e vou reflectir melhor.

COMPRADOR - Seja como for, segue atrás de mim, como deve fazer um criado meu.

MODELO CÉPTICO — Quem me garante que é verdade o que dizes?

COMPRADOR - O pregoeiro, a mina [que paguei] e os presentes.

MODELO CÉPTICO - Mas está alguém aqui presente?

COMPRADOR - Pois eu é que vou pregar contigo no moinho, para te convencer, usando o argumento mais fraco ${ }^{461}$, de sou o teu senhor.

MODELO CÉPTICO - Neste ponto, suspendo [o julgamento].

do Cepticismo é... a ignorância!

${ }^{460}$ Suspender o julgamento era uma das técnicas do céptico Pírron.

461 "o argumento mais fraco" ou o raciocínio injusto: alusão, p. ex., à discussão da Tese Justa e da Tese Injusta das Nuvens de Aristófanes. 
COMPRADOR - Náo, por Zeus!, pois já te demonstro como é 462. $^{2}$.

HERMES - Tu aí, deixa de resistir e segue atrás de quem te comprou... E quanto a vós, estais convocados para amanhã, pois vamos leiloar modelos de vida de cidadáos comuns, artesãos e comerciantes.

${ }^{462}$ Aqui parece que o Comprador agride, ou faz o gesto de agredir, o criado. 
OS RESSUSCITADOS OU O PESCADOR 
(Página deixada propositadamente em branco) 


\section{INTRODUÇÁo}

O título Os Ressuscitados ou O Pescador é o que consta dos manuscritos do grupo $\gamma$; os do grupo $\beta$ apresentam a ordem inversa: $O$ Pescador ou Os Ressuscitados. Optei pelo primeiro, atendendo ao facto de os "ressuscitados" (filósofos vindos do reino de Hades...: v. adiante) ocuparem a primeira e maior parte do diálogo (\$\$1-39), enquanto o “pescador” ocupa a segunda parte, bastante menor (\$39-52).

Em obra anterior (Filosofias em Leilão), Luciano havia apresentado uma imagem muitíssimo desfavorável dos diversos filósofos das numerosas escolas filosóficas. Terá mesmo dado a impressão, a muitos críticos e inimigos seus contemporâneos, de que o Autor atingira os grandes nomes da Filosofia, homens do passado e de reputação firmada... Na verdade - explica e explicita agora, mais do que fizera nessa obra anterior - Luciano diz que pretendera atacar, não os grandes filósofos de outros tempos, mas os falsos filósofos seus contemporâneos, cujas teorias não se coadunavam com o seu modo de vida depravado e com as suas ambições materialistas. O que Hermes pusera verdadeiramente em leiláo, eram os diversos MODELOS, ou VIDAS, ou MODELOS DE VIDA, tal como eram praticados e distorcidos no seu tempo. Mesmo assim, alguns desses "modelos de vida" valiam bastante mais que outros, p. ex.: Modelo Pitagórico (10 minas); Cínico (2 óbolos); Cirenaico (sem comprador!); Democrítico + Heraclítico (sem comprador!); Académico (2 talentos, quantia elevadíssima, comparada com outras); Epicurista (2 minas); Estóico (12 minas); Peripatético (20 minas); Céptico (1 mina).

Fosse como fosse, Luciano imagina que esses grandes luminares da Filosofia, informados (não se sabe como, mas, pelos vistos, mal informados) das injúrias que lhes eram feitas, requereram a Aidoneu (Hades ou Plutão) que lhes permitisse subir à terra dos vivos, a fim de fazerem justiça por suas próprias máos. O criminoso dava pelo nome de Parresíades, algo como "de linguagem desbragada", "desbocado"..., o qual, obviamente, se identifica com Luciano.

Sócrates aparece, logo de início, como o grande "comandante", que instiga os companheiros a sovar esse tal Parresíades com uma chuva de pedras, torrôes, cacos e umas boas cajadadas (v. \$1). 
Mas isto seria apenas o "aperitivo", pois a punição determinava a morte do criminoso. Diz Sócrates: "Mas de que modo iremos castigá-lo? Imaginemos contra ele uma morte variada, capaz de agradar a todos nós. Sim, ele merece sofrer sete mortes por cada um de nós." Sucessivamente, diversos filósofos dão a sua opinião, numa ordem curiosa: Devem empalá-lo, mas antes flagelá-lo, mas antes arrancar-lhe os olhos, mas antes cortar-lhe a língua. Vê-se bem aqui a fúria da "justiça directa”, sem julgamento, na pressuposição de que o acusado é culpado. A juntar a todos estes alvitres, Empédocles sugere que o lancem nas crateras do Etna, e Platão, por seu lado, acha que deve ser apedrejado até à morte.

Aqui, Parresíades reclama o seu direito de ser ouvido primeiro, antes de ser condenado. Depois de uma troca de citaçóes de poetas, chega-se à conclusão de que o caso deve ser resolvido por via judicial. Diz o acusado ( $\$ 8$, fim):

"Vós dais ouvidos à vossa ira e não admitis nada em favor da justiça. E no entanto, eu nunca suporia que a ira pudesse apoderar-se de Platão, ou de Crisipo, ou de Aristóteles, ou de qualquer outro de vós, mas, pelo contrário, vós parecieis-me as unicas pessoas isentas de tal sentimento. Ora, admiráveis senhores, não me mateis sem julgamento e sem sentença... Pelo menos era esta uma caracteristica vossa, a de não proceder nem pela força, nem a favor do mais forte, resolvendo os diferendos através de um processo judicial, em que apresentais os vossos argumentos e, por outro lado, escutais [os do adversário]. Assim, depois de escolher um juiz, acusai-me, quer vós todos um por um, quer elegendo um [que fale] por todos; e eu defender-me-ei das vossas acusaçóes. Então, caso se prove que eu cometi algum crime, e caso o tribunal dite a respectiva sentença contra a minha pessoa, eu submeter-me-ei, naturalmente, à devida pena, e vós não vos tereis atrevido a agir pela força. Mas se, pelo contrário, depois de ter prestado contas, eu for por vós reconhecido como estando inocente e isento de crime, os juizos absolver-me-ão, enquanto vós voltareis a vossa ira contra aqueles que vos enganaram e acirraram contra mim."

Enfim, é constituído o júri, composto pelos filósofos os quais, de modo nada canónico, mas por atrevida sugestão do próprio réu, são simultaneamente juízes e acusadores, ou seja, parte interessada; a presidência cabe à própria Filosofia, que agrega a si a Virtude, a Temperança, a Justiça, a Cultura e a Verdade... e mais umas quantas personagens, num conjunto 
imponente, donde só pode sair uma sentença absolutamente justa.

No $\$ 19$ (melhor: no \$21) começa propriamente o julgamento.

Com excepção do nome (Parresíades), os dados biográficos são, naturalmente, os de Luciano. Entre outros atributos, o réu declara-se (\$20 e nota) "odiador-de-fanfarróes, odiador-de-charlatães, odiador-de-mentirosos, odiador-de-pedantes: odeio todo esse género de pessoas detestáveis... e elas são muitas, como sabes." Mas Parresíades (Luciano, náo o esqueçamos) também se declara "amador de..."; enfim, "odeio os maus e elogio e amo os bons".

O discurso de acusação (katēgoría: $\kappa \alpha \tau \eta \gamma o p i ́ \alpha)$, é confiado a Diógenes, por ser, de entre todos o mais truculento; além do mais, Diógenes entendia ter contas especiais a ajustar com Parresíades, pois este pusera-o em leiláo por uns míseros dois óbolos.

Eis uma parte da acusação (\$25):

"Tendo sido, segundo se diz, um importante orador, abandonou os tribunais e a reputação neles adquirida e, apetrechado com todo o virtuosismo e com todo o vigor oratório, tudo isso acumulou contra nós, e agora náo cessa de dizer mal das nossas pessoas, chamando-nos charlatães e vigaristas e persuadindo as massas a troçarem de nós e a desprezarem-nos como pessoas sem valor. E sobretudo, fez com que nós próprios, e também tu, Filosofia, fôssemos odiados pela generalidade das pessoas, classificando de tagarelas e disparatadas as tuas doutrinas e virando para o lado da chicana as coisas sérias que tu nos ensinaste, de tal modo, que ele é aplaudido e elogiado pelos seus ouvintes, enquanto nós somos ultrajados. De facto, a multidão é assim mesmo por sua natureza, diverte-se com os que criticam e ultrajam, especialmente quando são amesquinhados os valores tidos por mais veneráveis, como certamente outrora se divertiam com Aristófanes e com Eupolis, quando estes levavam à cena aqui o Sócrates, de modo chicaneiro, compondo a seu respeito umas comédias absurdas. No entanto, aqueles [comediógrafos] atreviam-se a dizer tais coisas, mas contra um só homem isoladamente, e nas Dionisias, onde isso era tolerável, onde a chicana era considerada como fazendo parte da festa..."

Finalmente, é a vez de Parresíades pronunciar o seu longo

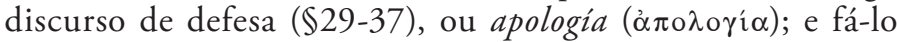
segundo as estritas regras da retórica. Começa por dizer que 
tudo o que Diógenes afirmou ainda é pouco, pois ele poderia muito bem ter mencionado factos ainda mais graves. Ou seja, o réu confessa tudo, a mais alguma coisa... só que... há um equívoco: Quem ele critica não são os veneráveis filósofos ali presentes, mas sim os pseudofilósofos, que, por detrás da aparência meramente exterior (longas barbas, manto, cajado, atitude grave e palavreado hipocritamente moralizante...), levam, na intimidade, uma vida depravada e torpemente materialista, que desmente todo o seu magistério.

Naturalmente - já o prevíamos com toda a certeza - o réu é absolvido por unanimidade. Todos se confessam emocionados, mas a declaração de voto de Diógenes, pelo facto de ter sido ele o representante da acusação, é, na sua concisão, particularmente digna de nota (\$38, fim): “Também eu, ó Filosofia, faço os maiores elogios ao homem, retiro a minha acusação e faço deste valente um amigo."

Também a presidente do júri, a Filosofia, entende dirigir uma breve palavra ao réu inocente (\$39, início): "Muito bem. Avança, Parresiades. Absolvemos-te da acusação; ganhaste por unanimidade, e fica sabendo que, de hoje em diante, és cá dos nossos."

$\mathrm{Na}$ sequência, e em consequência, do que ficou provado em tribunal, dá-se início a um segundo julgamento, agora contra os falsos filósofos denunciados por Parresíades, o qual, muito justamente, irá figurar como acusador.

A proclamação feita pelo Silogismo, convocando os filósofos, a fim de se justificarem perante a Filosofia e a Virtude, não atrai nenhum, mas antes fá-los fugir a sete pés. Parresíades, porém, que os conhece como ninguém, demonstra ao Silogismo como é que se faz uma convocatória eficaz (mas tremendamente cínica) (\$41):

"Escutai! Silêncio! Todos quantos se têm na conta de filósofos e todos quantos pensam que essa designação lhes assenta bem, que subam aqui à Acrópole, para uma distribuição. Serão dadas duas minas a cada um, e ainda um bolo de sésamo. Todo aquele que apresentar uma barba farfalhuda, receberá, como suplemento, uma cesta de passas de figo. Não é preciso que cada um traga consigo nem bom senso, nem justiça, nem moderação. Na verdade, se não tiverdes essas qualidades, elas também não são necessárias. Deveis trazer, sem falta, cinco silogismos, pois sem eles não é permitido 
ser filósofo." E como suplemento, promete dar dois talentos de ouro àquele que se revelar mais eloquente.

Acorre gente de todas as escolas: platónicos, pitagóricos, estóicos, peripatéticos, epicuristas, académicos, cínicos..., todos a quererem ser atendidos em primeiro lugar. Todavia, quando a Filosofia lhes revela o motivo da convocação, dá-se uma debandada geral.

É então preciso "pescá-los" - daí o segundo título: O Pescador -, e separar os numerosos falsos filósofos dos poucos verdadeiros: Estes serão coroados, ao passo que aos outros será aplicado um ferro em brasa, na fronte, com a figura de uma raposa ou de um macaco.

Enfim, no $\$ 47$ começa a "pescaria". Pescam um cínico, um platónico, um peripatético, um estóico... Aqui, a Filosofia entende abreviar as coisas (ou seja, Luciano não quer correr o risco de alongar excessivamente o texto), e dá as últimas ordens (\$52):

"E agora vós os dois, tu, Parresíades, mais a Averiguação, ide fazer a ronda por todos esses tipos e, conforme eu disse, coroai-os ou marcai-os com um ferro em brasa".

E é deste modo que Luciano se defende da gravíssima acusação, segundo a qual ele ofendera, indiscriminadamente, os grandes vultos da Filosofia. Na verdade, porém, a obra Filosofias em Leilão prestava-se a essa confusão, pois as personagens não são claramente identificadas pelo nome, mas pela terra de origem ou pelas doutrinas que defendem. Por vezes, são os vocativos que indicam os diversos interlocutores. É muito significativo o facto de o editor da "Loeb" indicar, no texto grego, p. ex., PITÁGORAS, e na tradução PITAGÓRICO. Afinal, o texto grego refere-se-lhe claramente, não como "Pitágoras", mas como "Pitagórico" (v. Filosofias em Leilāo, \$2, 2a fala de Hermes). Para concluir este assunto, recorde-se que os manuscritos do tempo dos autores não se apresentavam com a clareza das nossas modernas ediçôes, com a impressionante indicação, geralmente em maiúsculas, das diversas personagens do diálogo. Naturalmente, os manuscritos medievais, depois de tantas cópias, nem sempre concordam uns com os outros... 
(Página deixada propositadamente em branco) 


\section{Os Ressuscitados ou O Pescador ${ }^{463}$}

1. SÓCRATES - Chega-lhe, chega-lhe, a esse maldito, com uma chuva de pedras! Manda-lhe também com torróes! Depois atira-lhe cacos! Dá-lhe com o cajado, a esse criminoso! Tem cuidado, não fuja ele. Tu, Platão, chega-lhe, e tu também, Crisipo, e tu aí, e todos à uma! Marchemos contra ele em fila cerrada,

Que um alforge outros ajude, | e um cajado outros cajados ${ }^{464}$,

pois ele é nosso inimigo comum, e não há nenhum de nós a quem ele não tenha ultrajado. Tu, Diógenes, agora, mais que nunca, serve-te do teu cajado. Que nenhum afrouxe, que ele pague o justo preço por ser tão desbocado... Mas que é isto? Vós, Epicuro e Aristipo, já estais cansados? Pois náo devíeis estar.

Que sejais homens, ó sábios, | lembrai vossa ardente fúria ${ }^{465}$.

2. Tu, Aristóteles, apressa-te... Vamos... mais depressa. Muito bem. A fera está apresada. Já te apanhámos, meu patife. Em breve saberás que espécie de homens somos nós, que tu caluniaste... Mas de que modo iremos castigá-lo? Imaginemos contra ele uma morte variada, capaz de agradar a todos nós. Sim, ele merece sofrer sete mortes por cada um de nós.

UM FILÓSOFO ${ }^{466}$ - A minha opinião é que o tipo deve ser empalado ${ }^{467}$.

SEGUNDO FILÓSOFO ${ }^{468}$ — Mas, por Zeus!, primeiro deve ser flagelado.

${ }^{463}$ É esta a ordem nos mss. do grupo $\gamma$; os mss. do grupo $\beta$ têm O Pescador ou Os Ressuscitados (V. Introdução).

${ }^{464}$ Iliada, II, 363, mas, em vez alforge e cajado, diz fratria e tribo.

${ }^{465}$ Verso de Homero, Iliada, VI, 112, com uma alteração: Luciano diz sábios, onde Homero tem amigos.

466 Alguns editores atribuem esta fala a PLATÃO.

${ }^{467}$ A empalação consistia em espetar um pau ou ferro aguçado no ânus do desgraçado e deixá-lo assim exposto, até morrer...

${ }^{468}$ Alguns editores atribuem as falas deste Filósofo e dos dois seguintes ao Filósofo precedente, que proporia os três suplícios. Com esta divisão de "se um diz mata!, o outro diz esfola!, a cena fica ainda mais bárbara... 
TERCEIRO FILÓSOFO - E antes disso devem arrancar-lhe os olhos.

QUARTO FILÓSOFO - E ainda antes devem cortar-lhe a língua.

SOCCRATES - Que é que te parece, ó Empédocles?

EMPÉDOCLES - Que deve ser lançado nas crateras [do Etna] $]^{469}$, para aprender a não insultar os melhores que ele.

PLATÁO - Mesmo assim, seria melhor, à semelhança de um Penteu ${ }^{470}$ ou de um Orfeu,

ter seu destino cumprido | por pedras dilacerantes ${ }^{471}$,

para que cada um de nós se fosse daqui com a sua parte.

3. PARRESÍADES ${ }^{472}$ - De maneira nenhuma! Pelo Protector dos Suplicantes ${ }^{1473}$, poupai-me.

PLATÃO - Está decidido. Não escaparás. Vê lá o que diz Homero:

entre leôes e humanos $\mid$ não há fiéis juramentos ${ }^{474}$.

PARRESÍADES - No entanto, suplico-vos, citando também eu Homero. Talvez respeiteis os seus versos e náo desdenheis de mim, ao recitar uns fragmentos seus ${ }^{475}$ :

Poupai-me, não sou vilão, | e aceitai digno resgate:

${ }^{469}$ O texto diz só (no pl.) "nas crateras", que entendo serem do Etna (Nordeste da Sicília), pelo facto de essa sugestão ser dada por Empédocles, o qual se precipitou no vulcáo do monte Etna.

${ }^{470}$ Penteu e Orfeu foram linchados, respectivamente, pelas Ménades (companheiras de Dioniso) e por mulheres da Trácia...

${ }^{471}$ Verso de uma tragédia de Eurípides, de que apenas nos chegaram algumas citaçóes...

${ }^{472}$ Este Parresíades (cujo nome sugere parrhèsías "liberdade de linguagem”, "franqueza") é, sem tirar nem pôr, o próprio Luciano, como lá para diante se verá com alguma clareza.


tar, segundo as regras, como port. Icésio (!)... que me pareceu demasiado rebarbativo para o leitor comum: "Pelo Icésio!".......

${ }^{474}$ Homero, Iliada, XXII, 262.

475 "recitar fragmentos" (ou episódios) é, aqui, o sentido de rhapsōidéo $(\hat{\rho} \alpha \psi \omega \delta \varepsilon \dot{\varepsilon} \omega)$. De facto, os dois versos são tirados de três passos da Ilíada, com alteraçóes da lavra de Luciano, 
[resgate] de cobre e ouro, |que os próprios sábios estimam.

PLATÃO - Nós também não teremos falta de Homero, [com versos] contra ti. Ora escuta:

Não ponhas, mau palrador, | em teu pensamento a fuga, prometendo dar-nos ouro, | quando em nossas mäos caiste ${ }^{476}$.

PARRESÍADES - Estou desgraçado! Homero, a minha maior esperança, de nada me serve. Tenho, pois, de me refugiar em Eurípides. Talvez esse me salve:

Não me mates; não é lícito | dar a morte ao suplicante $e^{477}$.

PLATÃO — Então e este também não é de Eurípides?

Não deverão sofrer dano $\mid$ os que dano provocaram? $?^{278}$

\section{PARRESÍADES -}

Só por causa de palavras | agora ides matar-me? ${ }^{249}$

PLATÃO — Por Zeus!, Eurípides também diz:

De bocas desaforadas

e de loucuras sem lei

o fim é calamitoso.

4. PARRESÍADES - Pois bem: Uma vez que estais absolutamente determinados em matar-me, e eu não tenho nenhum meio de escapar, pelo menos dizei-me quem sois vós, que mal irreparável vos fiz eu, para estardes tâo cruelmente irritado comigo e me terdes apresado para me dar a morte.

PLATÃO - Que graves ofensas tu cometeste contra nós, é o que deves perguntar a ti próprio, meu tratante, e a esses

${ }^{476}$ Iliada, X, 447-448, com alteraçóes.

${ }^{477}$ Fragmento de um tragédia perdida de Eurípides.

${ }^{478}$ Eurípides, Orestes, 413.

${ }^{479}$ Fragmento de um tragédia perdida, aparentemente de Eurípides. 
teus belos discursos ${ }^{480}$, nos quais disseste tanto mal da própria Filosofia e nos ultrajaste a nós, ao pores-nos em leiláo, a nós, homens sábios e - o mais grave de tudo - homens livres ${ }^{481}$. Entâo nós, indignados com as tuas palavras, solicitámos a Aidoneu ${ }^{482}$ que nos deixasse subir até junto de ti, por um curto intervalo de tempo — nós, [quer dizer,] aqui o Crisipo, Epicuro, Platão (eu próprio), ali o Aristóteles, aqui o Pitágoras, que está muito calado, Diógenes e todos quantos tu vilipendiaste nos teus discursos.

5. PARRESÍADES - Já respiro de alívio, pois vós não ides matar-me, quando souberdes que homem eu sou [e o que penso] a vosso respeito. Portanto, deitai fora as pedras... ou antes, conservai-as, que já ireis usá-las contra aqueles que as merecem.

PLATÃO - Estás doido, tens de morrer ainda hoje, pois muito brevemente

uma túnica de pedra, | por teus crimes, vestirás ${ }^{483}$.

PARRESÍADES - E no entanto, nobilíssimos senhores, esse homem, o único, de entre todos, que vós devíeis louvar, que vos é muito chegado, vosso simpatizante e concordante com o vosso pensamento, esse homem — se não é grosseria dizê-lo —, defensor das vossas doutrinas, ficai sabendo que é esse mesmo que vós ireis matar (se ireis mesmo matar), a ele que tanto se tem esforçado em vosso favor. Tende, pois, cuidado em não procederdes, também vós, como a maioria dos filósofos de hoje em dia, ao mostrar-vos ingratos, coléricos e esquecidos relativamente a um homem que é [afinal] um vosso benfeitor.

480 "discursos": Platão refere-se concretamente à recente obra de Luciano, Filosofias em Leilão.

481 Trata-se do crime de "escravização de pessoa livre", mais propriamente "rapto e venda, como escravo, de uma pessoa livre, gr. andrapodismós

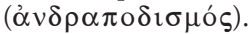

${ }^{482}$ Aidoneu é outro nome de Hades ou Plutão, o soberano do Inferno.

${ }^{483}$ Homero, Ilíada, III, 57; "uma túnica de pedra vestirás”, quer dizer, “serás apedrejado (a ponto de ficares 'vestido' de pedras)”. Em Homero, trata-se de palavras dirigidas por Heitor a seu irmáo Páris, a quem (segundo Heitor) mais valera náo ter nascido, ou então ter morrido antes de casar e ter filhos. Se os Troianos não fossem uns cobardes, há muito que o teriam 'vestido' com uma túnica de pedra... 
PLATÃO - Mas que falta de vergonha! Será que ainda devemos estar-te gratos pela tua maledicência? Cuidas que estás realmente a dirigir-te a escravos? Ou contarás, entre os serviços a nós prestados, um táo grande ultraje e esse teu desbragamento verbal?

6. PARRESÍADES - Mas em que é que eu alguma vez vos ultrajei, eu que durante toda a vida vos tenho admirado, vos tenho elogiado e tenho convivido com as obras que vós deixastes? Todas essas palavras ${ }^{484}$ que eu emprego, donde é que elas vieram, senão tomadas de vós e colhidas à maneira da abelha, a fim de as transmitir aos homens? Estes elogiam e reconhecem cada flor, de que obra, de que autor e de que maneira a colhi; nas suas palavras, é a mim que eles louvam pela "colecção de flores", mas na realidade é a vós e ao vosso jardim [que louvam], a vós, que produzistes tais e tăo variadas flores, de múltiplas cores, [isto] desde que uma pessoa saiba escolhê-las, entrelaçá-las e adequá-las, de modo que não destoem umas das outras. Existe, pois, alguma pessoa, que, tendo recebido de vós tais bens, se atreva a dizer mal de vós, seus benfeitores, aos quais essa pessoa deve a sua reputação? Só se fosse de natureza igual à de Tâmiris ou de Êrito: aquele, por querer competir no canto com as Musas, das quais havia recebido o [dom do] canto, e este, por querer rivalizar no arco com Apolo, o qual lhe concedera a arte do arco.

7. PLATÁO - Esse teu discurso, meu caro, foi pronunciado à maneira dos oradores... mas [todo] ele é contrário ao tema $\mathrm{e}$ demonstra um atrevimento ainda mais insuportável, na medida em que à injustiça se junta a ingratidáo, já que, segundo afirmas, tendo recebido de nós as setas, as desferiste contra nós, propondo-te como único objectivo falar mal de nós. Foi esta a paga que recebemos de ti, por te termos aberto de par em par o nosso jardim e não te termos proibido de colher flores e sair de lá com o regaço bem repleto. Pois por isso mesmo ainda mais mereces morrer.

8. PARRESÍADES - Reparai: Vós dais ouvidos à vossa ira e não admitis nada em favor da justiça. E no entanto, eu nunca suporia que a ira pudesse apoderar-se de Platão, ou de

484 "palavras"... frases, pensamentos... 
Crisipo, ou de Aristóteles, ou de qualquer outro de vós, mas, pelo contrário, vós parecíeis-me as únicas pessoas isentas de tal sentimento. Ora, admiráveis senhores, não me mateis sem julgamento e sem sentença... Pelo menos era esta uma característica vossa, a de não proceder nem pela força, nem a favor do mais forte, resolvendo os diferendos através de um processo judicial, em que apresentais os vossos argumentos e, por outro lado, escutais [os do adversário]. Assim, depois de escolher um juiz, acusai-me, quer vós todos um por um, quer elegendo um [que fale] por todos; e eu defender-me-ei das vossas acusaçóes. Então, caso se prove que eu cometi algum crime, e caso o tribunal dite a respectiva sentença contra a minha pessoa, eu submeter-me-ei, naturalmente, à devida pena, e vós não vos tereis atrevido a agir pela força. Mas se, pelo contrário, depois de ter prestado contas, eu for por vós reconhecido como estando inocente e isento de crime, os juízos absolver-me-ão, enquanto vós voltareis a vossa ira para aqueles que vos enganaram e acirraram contra mim.

9. PLATÃO - Isso é o mesmo que "lançar o cavalo na planície" ${ }^{485}$... para dares a volta aos juízes e escapares... Pelo menos, diz-se para aí que tu és um excelente orador e especialista em processos e muito astuto na argumentação. Mas então quem é que tu pretendes que seja o juiz, uma pessoa a quem tu não possas subornar (como vós ${ }^{486}$ tantas vezes fazeis) e persuadir a ditar uma sentença injusta favorável a ti?

PARRESÍADES - Quanto a isso, ficai sossegados, pois eu mesmo não gostaria de ter um árbitro desse tipo, suspeito e ambíguo, que me vendesse o seu voto. Vejam: cá por mim, elejo como juíza, juntamente convosco, a própria Filosofia em pessoa.

PLATÃO — Mas quem será o acusador, se somos nós ${ }^{487}$ a julgar?

PARRESÍADES - Vós mesmos sereis acusadores e juízes. Náo tenho medo nenhum desse facto, pois estou seguro da justiça [que me assiste] e espero poder defender-me cabalmente.

485 "lançar o cavalo na planície”, provérbio que significa "dar rédea solta a alguém, para que ela se espraie livremente”. Para um advogado eloquente e persuasivo, a "planície" é a cena do tribunal...

486 "vós... fazeis": Platão generaliza a todos (ou a muitos) advogados.

487 "nós"... os filósofos, aqui identificados com a Filosofia... 
10. PLATÃO - Que fazemos, ó Pitágoras, e tu, Sócrates? Parece-me que o homem não solicita nada que náo seja razoável, ao pretender ser julgado.

SÓCRATES - Que outra coisa, a não ser dirigirmo-nos ao tribunal, levando connosco a Filosofia, e escutarmos o que ele tem a dizer em sua defesa? Sim, que isso de [condenar] antes do julgamento não é próprio de nós, mas de gente terrivelmente vulgar, de certas pessoas irascíveis, que acham que a justiça consiste na violência. Deste modo, ofereceríamos argumentos aos que pretendem acusar-nos, se lapidássemos um homem que nem sequer pôde falar em sua defesa, tanto mais que nós próprios dizemos apreciar a justiça. Que poderia eu dizer de Ânito e de Meleto, meus acusadores, ou dos meus juízes de entáo, se este homem morresse sem ter obtido uma gota de água ${ }^{488}$ sequer?

PLATÂO - Aconselhas muitíssimo bem, ó Sócrates. Portanto, vamos ter com a Filosofia. Ela que julgue [o caso], que nós conformar-nos-emos com o que ela decidir.

\section{PARRESÍADES - Muito bem, meus sapientíssimos} senhores, esse procedimento é melhor e mais consentâneo com a lei. Em todo o caso, guardai as vossas pedras, conforme eu disse, pois em breve ireis precisar delas no tribunal... Mas... onde poderemos encontrar a Filosofia? Realmente, não sei onde ela mora. E no entanto, vagueei durante muitíssimo tempo em busca da sua morada, a fim de frequentá-la. Depois, fui procurar uns certos indivíduos que envergavam mantos, usavam barbas farfalhudas, que afirmavam regressar da morada dela; cuidando que eles sabiam, interrogava-os. Eles, porém, ainda mais ignorante que eu, ou não me davam qualquer resposta, a fim de não serem apanhados na sua ignorância, ou me indicavam uma porta em vez da outra. Por isso, nunca, até hoje, fui capaz de achar essa morada...

12. ... Muitas vezes, ou por conjectura minha, ou tomando alguém por guia, fui parar a certas portas, na forte esperança de tê-la, enfim, encontrado, a julgar pela multidáo dos que entravam e saíam, todos eles de olhar sombrio, de grave figura e ar de pensador. Entấo misturei-me com eles e entrei também.

488 "sem ter obtido uma gota de água": Referência à água da clepsidra, que marcava o tempo de uso da palavra. 
Aí vi uma mulherzinha nada ingénua, apesar de se vestir com muita simplicidade e sem atavios. Mas tornou-se-me imediatamente claro que ela fazia com que o aspecto descuidado da sua cabeleira parecesse náo desprovido de beleza, e que a sua maneira de traçar e deixar cair o manto náo era desprovida de arte. Era óbvio que ela se enfeitava com tais artifícios e se servia do seu aparente aspecto desleixado como [factor de] sedução. Até se adivinhava um pouco de alvaiade e de rouge; o seu modo de falar era o de uma cortesá, e comprazia-se com ver a sua beleza elogiada pelos seus apaixonados, e se algum deles lhe oferece um presente, ela recebe-o avidamente; quando está sentada ao lado dos mais ricos, nem sequer olha para os apaixonados pobres. Muitas vezes, quando ela, como que por descuido, deixava ver o colo desnudado, eu via colares de ouro mais grossos que correntes ${ }^{489}$. Ao ver tais coisas, imediatamente me retirei, lamentando claramente aqueles infelizes que se deixavam levar por ela, [presos] não pelo nariz ${ }^{490}$, mas pela barba, e que, à semelhança de Ixíon $^{491}$, se agarravam a uma imagem, em vez de Hera.

13. PLATÃO - Num ponto falaste muito bem. De facto, essa porta não é bem visível nem conhecida de todos. Todavia, não precisarás de caminhar até à sua casa, porquanto esperamo-la aqui no Ceramico ${ }^{492}$. Ela está por aí a chegar, vinda da

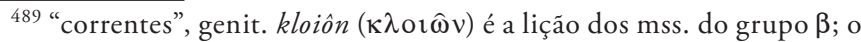

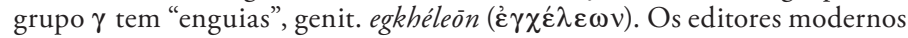
dividem-se. A segunda interpretação, por parecer menos “óbvia”, poderia ser, como mandam as regras gerais da restituição do texto original, a nossa preferida, a "lição mais difícil" (lectio difficilior). O leitor que leia como muito bem entender.

490 “[presos] ... pelo nariz": Em port. diz-se "presos belo beicinho". Fiquemos com a tradução literal...

${ }^{491}$ Ixíon, que havia sido curado por Zeus da sua loucura derivada de um crime hediondo, atreveu-se a apaixonar-se por Hera, esposa de Zeus. Entáo este (ou Hera) fabricou uma imagem igual à de Hera, feita de uma nuvem, com a qual Ixíon teve relaçóes, donde (imagine-se!) nasceu o Centauro, pai dos Centauros...

492 "Ceramico", e não *Cerâmico (mas sim adj. cerâmico "de barro"...) é o bairro dos oleiros e uma praça em Atenas. Note gr. Kerameikós (Kع $\rho \alpha-$ $\mu \varepsilon \imath \kappa o ́ \varsigma)$, donde lat. Ceramīcus, palavra grave, base da forma port., também grave. O ditongo gr. - ei- (- $\left.\varepsilon \imath_{-}\right)$evolve (sempre com a grafia - $\varepsilon 1-$, salvo curiosos e preciosos erros de ortografia!), já em gr., para [-ē-: $e$ fechado e longo], e daí, ainda em gr,. para [-i-i: $i$ longo]. Por vezes, o lat. tem as duas 
Academia, a fim de passear na Pécile ${ }^{493}$, pois é seu hábito fazer isso todos os dias. Mas ei-la que se aproxima. Estás vendo aquela [figura feminina] de aspecto recatado, de ar grave e olhar doce, caminhando suavemente absorta em pensamentos?

PARRESÍADES - Vejo muitas iguais, quer pelo ar grave, quer pelo andar, quer pelo modo de traçar o manto. No entanto, certamente que só uma de entre elas é a verdadeira Filosofia.

PLATÃO - Dizes bem. Mas basta que ela fale, para mostrar quem é.

14. FILOSOFIA - Oh! Que fazem cá em cima [na terra] Platão, Crisipo, Aristóteles e todos os outros, a própria nata dos meus ensinamentos? Porque viestes de novo à vida? Porventura vos entristecia alguma coisa lá em baixo? É que vós pareceis mesmo furiosos. E quem é este fulano que vós trazeis prisioneiro? Será, talvez, algum violador de túmulos, ou um assassino, ou um sacrílego?

PLATÃO — Sim, Filosofia, por Zeus!, ele é o mais ímpio dos sacrílegos, pois atreveu-se a dizer mal de ti, a mais santa [das criaturas], bem como de todos nós, que, tendo aprendido contigo alguma doutrina, a transmitimos aos nossos vindouros.

FILOSOFIA - Quer dizer que vos escandalizastes pelo facto de alguém vos ter ofendido, mesmo sabendo que coisas eu escutei nas Dionísias, vindas da Comédia, a qual, mesmo assim, eu considero minha amiga, a quem nunca processei nem acusei, e a quem deixo divertir-se a seu bel-prazer, como é tradição nesse festival?! Na verdade, eu sei que nada de muito mau resulta de um gracejo, mas, pelo contrário, aquilo que for belo, tal como o ouro limpo pelos golpes [da cunhagem], brilha com maior intensidade e torna-se mais luzente. Vós, pelo contrário, não sei porquê, ficastes furiosos e escandalizados. Mas então porque é que lhe apertais o pescoço?

PLATÃO - Nós pedimos licença por um só dia, para virmos aqui procurá-lo, a fim de o fazermos sofrer a [devida] punição pelos crimes que tem cometido. $\mathrm{Na}$ verdade, chegavam-nos rumores sobre aquilo que ele publicamente dizia contra nós.

formas (-è-e -ī-), p. ex., Alexandrēa / Alexandrīa, Darēus / Darīus... Um conselho: Náo se envergonhe de dizer Ceramico, palavra grave.

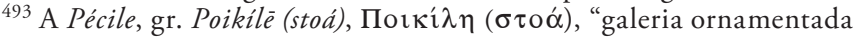
com pinturas" de Polignoto, em Atenas, era a zona onde funcionava a Escola Estóica. 
15. FILOSOFIA - E então vós quereis dar-lhe a morte sem julgamento e sem que ele se justifique? No entanto, é bem evidente que ele pretende dizer alguma coisa.

PLATÂO - Nada disso, pois remetemos o caso para a tua pessoa, e serás tu quem porá fim à demanda, como [melhor] te parecer.

FILOSOFIA - E tu, que é que dizes?

PARRESÍADES - A mesma coisa, minha Senhora Filosofia, tu que és a única capaz de descobrir a verdade. Na verdade, só depois de muito suplicar é que, a muito custo, lá consegui que o caso vos fosse entregue.

PLATÃO - Agora, meu biltre, é que a tratas por "minha Senhora"? Ainda recentemente ${ }^{494}$, porém, apresentavas a Filosofia como sendo a coisa mais desprezível, ao pores em leiláo, perante uma grande multidão de gente, sucessivamente e por dois óbolos $^{495}$, cada uma das doutrinas filosóficas.

FILOSOFIA - Vejam lá bem se ele disse mal, não da Filosofia, mas de charlatães que cometem muitos actos abomináveis em nosso nome.

PARRESÍADES - Já vais sabê-lo, para o que basta dispores-te a escutar a minha defesa.

FILOSOFIA - Vamos até ao Areópago, ou melhor, à própria Acrópole, de modo que, desse posto de observação, possamos ao mesmo tempo observar tudo quanto se passa lá em baixo na cidade ${ }^{496}$...

16. ... Entretanto vós, meus amigos, ide passear na Pécile ${ }^{497}$, que eu irei ter convosco assim que a causa tiver sido julgada.

494 "Ainda recentemente": Refere-se à obra, lida em público e depois publicada, Filosofias em Leilão, cujo título Platão (e os outros filósofos) entendem como Filósofos em Leilão — diferença subtil, mas grave, que Parresíades (Luciano) irá comentar...

${ }^{495} \mathrm{Na}$ verdade, só o Modelo Cínico é que foi vendido por dois óbolos; Os Modelos Cirenaico, Democrítico e Heraclítico não obtiveram comprador; quanto aos outros: Modelo Pitagórico: 10 minas; Modelo Académico: 2 talentos; Modelo Estóico: 12 minas; Modelo Peripatético: 20 minas; Modelo Céptico: 1 mina. Mesmo aqueles que foram vendidos entre uma e vinte minas poderiam queixar-se do preço mais ou menos moderado ou até desprestigiante. De toda a maneira, Platẫo está longe de ser exacto... talvez devido ao facto de terem sido informados por "rumores", boatos (v. supra, $\$ 14$, fim). O Modelo Académico é o mais valioso...

${ }^{496}$ Esta parte da fala é, por alguns editores, atribuída ainda a Parresíades.

497 "Pécile": V. nota, \$13. 
PARRESÍADES - Mas... ó Filosofia, quem são aquelas [pessoas] ${ }^{498}$ ? Realmente, têm um aspecto muito decente.

FILOSOFIA — Esta aqui, muito viril, é a Virtude; aquela ali é a Temperança, e a seu lado está a Justiça; a que vem na frente é a Cultura, e a outra, quase invisível e de tom incerto, é a Verdade.

PARRESÍADES - Não estou a ver essa de que falas.

FILOSOFIA - Será que não vês aquela ali, sem quaisquer adornos, nua, esquiva e escorregadia?

PARRESÍADES — Sim, agora vejo, embora a custo... Mas... porque náo trazes também estas, para que o tribunal fique cheio e completo? Além disso, pretendo fazer subir à tribuna a Verdade, na qualidade de minha advogada de defesa.

FILOSOFIA - Por Zeus!, acompanhai-me também vós. Realmente, não vos será penoso julgar somente uma causa, tanto mais que vai incidir sobre os nossos interesses.

17. VERDADE - Ide vós, que eu não tenho a mínima precisão de escutar aquilo que desde há muito sei como é.

FILOSOFIA - Mas... ó Verdade, em caso de necessidade julgarás juntamente connosco e esclarecerás os pormenores.

VERDADE - Nesse caso, posso levar comigo estas minhas duas criadinhas, que me são absolutamente dedicadas?

FILOSOFIA - Claro que sim, quantas quiseres.

VERDADE - Sigam-nos, Liberdade e Franqueza, a fim de podermos salvar este pobre homenzinho, que é nosso apaixonado e está correndo um grande perigo sem qualquer motivo justo... E tu, Refutação ${ }^{499}$, aguarda-nos aqui.

PARRESÍADES - De maneira nenhuma, minha Senhora, que venha também esta, e mais que fossem, pois não é contra feras vulgares que eu terei de lutar, mas sim contra charlatães, homens difíceis de refutar e que sempre inventam escapatórias... pelo que a Refutação é necessária.

498 "aquelas [pessoas]": O texto diz tínes ( $\tau$ ívعৎ), masc.-fem. pl., e muito bem, já que (como se verá adiante) surgirá uma figura masculina, a Refutação... que não houve forma de traduzir por um nome masculino... Talvez Contraditório...

499 "Refutação": Como se disse em nota precedente, o termo grego é masculino, Élenkhos ("E $\lambda \varepsilon \gamma \chi 0 \varsigma$ ), que não houve maneira de verter por um nome masculino... talvez "Contraditório"... 
REFUTAÇÃO — Sim, absolutamente necessária... e melhor ainda seria, juntasses também a Demonstração.

VERDADE - Sigam-me todas, já que pareceis necessárias ao julgamento.

18. PLATÃO - Estás a ver, ó Filosofia? [O fulano] associa a si, contra nós, a Verdade.

FILOSOFIA - Será que vós, Platão, Crisipo e Aristóteles, receais que ela, que é a Verdade, minta em seu favor?

PLATÃO - Não se trata disso, mas o tipo é terrivelmente manhoso e adulador, pelo que acabará por convencê-la [daquilo que não é].

FILOSOFIA - Tende confiança, que não acontecerá nada de injusto, já que está aqui presente a Justiça. Vamos, pois, lá acima...

19. ... Ora bem, diz-me cá o teu nome.

PARRESÍADES - O meu nome? Parresíades ${ }^{500}$, filho de Alétion, filho de Elênxicles.

FILOSOFIA - Qual o teu país natal?

PARRESÍADES - Sou sírio, Filosofia, nas margens do Eufrates. Mas para quê tudo isso? $\mathrm{Na}$ verdade, sei de muitos destes meus adversários que não são menos bárbaros de nascimento que eu, mas, apesar disso, a sua índole e a sua cultura não condizem com as dos Solenses ${ }^{501}$, dos Cipriotas, dos Babilónios ou dos Estagiritas. Todavia, para ti, não faz qualquer diferença que um homem tenha uma pronúncia bárbara, desde que a sua maneira de pensar se revele recta e justa.

20. FILOSOFIA - Dizes bem. De facto, fiz uma pergunta descabida. E qual é a tua profissão? Sim, pelo menos isso é bom que eu saiba.

500 "Parresíades ... Alétion ... Elênxicles": Nomes inventados, mas com um significado preciso, que sugerem as ideias de liberdade de palavra, verdade e refutação. Note que só na resposta seguinte é que Parresíades faz uma referência a Luciano, indicando a sua pátria: a Síria.

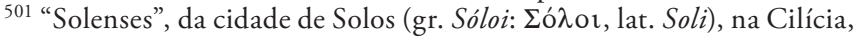
pátria de Crisipo; Cipriotas, de Chipre, nomeadamente da cidade de Cítio, pátria de Zenão, fundador da Escola Estóica (não confundir com Zenáo de Eleia); Babilónios, da cidade de Seleucia (Ásia Menor), terra natal de Diógenes o estóico (não o cínico); Estagiritas, da cidade de Estagiros, pátria de Aristóteles. 
PARRESÍADES - Sou odiador-de-fanfarrôes ${ }^{502}$, odiador-de-charlatães, odiador-de-mentirosos, odiador-de-pedantes: odeio todo esse género de pessoas detestáveis... e elas são muitas, como sabes.

FILOSOFIA - Por Hércules! Exerces uma profissão bem odiosa.

PARRESÍADES - Dizes bem. Realmente, estás vendo a quantidade de pessoas para quem me tornei odioso, e devido à qual [profissão] estou correndo perigo. Todavia, também conheço perfeitamente a profissão contrária. Refiro-me àquela que tem por primeiro elemento philo- [amante de]: amante-da-verdade ${ }^{503}$, amante-da-beleza, amante-da-simplicidade e todas quantas são da família de phileîsthai [amar]. No entanto, são muito poucos os que se mostram dignos desta profissão, ao passo que os que militam na [profissão] contrária e são íntimos amigos do ódio são mais de cinquenta mil. Desta forma, corro o risco de, por falta de prática, desaprender uma, ao passo que me tornei um perito na outra.

FILOSOFIA - Mas não deve ser assim, porquanto, como sói dizer-se, um e outro sentimentos vêm do mesmo [coração]. Portanto, náo separes essas duas profissóes, pois, parecendo serem duas, são uma só.

PARRESÍADES - Tu, Filosofia, conheces essas coisas melhor que eu. Mas eu sou desta conformidade: odeio os maus e elogio e amo os bons.

21. FILOSOFIA - Ora bem, estamos mesmo onde devíamos; procedamos ao julgamento, algures por aqui no pórtico de [Atena] Políade ${ }^{504}$. Tu, sacerdotisa, prepara-nos os bancos, enquanto nós vamos prestar culto à deusa.

502 “odiador-de-fanfarrôes", etc.: Nos dicionários, estes quatro compostos são atribuídos somente a Luciano, mas os compostos com este $1^{\circ}$ elemento são tão frequentes, que náo me atrevo a afirmar peremptoriamente que sejam da sua invenção. O $1^{\circ}$ elemento, mis- (quando seguido de vogal: $1^{\circ}$ ex.) ou miso- exprime a ideia de "odiar" (miséo: $\left.\mu \iota \sigma \varepsilon ́ \omega\right)$. Atrevi-me a traduzir de forma "náo dicionarizada", de algum modo imitando o (provável) neologismo (provavelmente) forjado por Luciano.

503 “amante-da-verdade", etc.: São muito frequentes os compostos de $1^{\circ}$ elemento phil(o)- (port. fil(o)-); Os dois primeiros ocorrem em diversos autores; o último, segundo os dicionários, só ocorrerá (?) em Luciano.

504 [Atena] Políade, ou seja "protectora da cidade"; ocupava, com Erecteu (Erekhtheús: 'E $\rho \varepsilon \chi \theta \varepsilon v ́ \varsigma)$, o mesmo templo, o Erecteu (Erékhtheion: 'E $\rho \varepsilon \chi \theta \varepsilon \imath o v)$. Note que as normas de adaptação ao port. fazem que o nome do herói e o do templo coincidam. 
PARRESÍADES - Ó Políade, vinde até mim como minha aliada contra os charlatães, lembrada de quantas coisas escutas todos os dias da boca desses perjuros! Só tu, que habitas neste alto lugar, vês os actos que eles cometem. Eis chegada a hora de os punires. Se porventura vires que eu estou quase a ser vencido, e que os votos pretos sáo em maior número, acrescenta o teu próprio [voto] e salva-me.

22. FILOSOFIA - Muito bem. Já estamos nos nossos lugares, perante vós, prontas ${ }^{505}$ para escutar as vossas palavras. Quanto a vós, escolhei um de entre todos, que vos pareça capaz de melhor pronunciar a acusaçáo; entáo formulai em conjunto o libelo acusatório e apresentai as vossas provas. $\mathrm{Na}$ verdade, não é possível falardes todos ao mesmo tempo. E tu, Parresíades, defender-te-ás logo a seguir.

PLATÃO - Quem de entre nós será o mais capaz de introduzir a queixa?

CRISIPO - Tu, Platão. De facto, essa tua admirável inteligência, esse teu belo estilo refinadamente ático, essa tua graça carregada de persuasão, bem como a junção, a precisão e a sedução das demonstraçóes feitas oportunamente - tudo isso conflui em ti num só conjunto. Assim sendo, aceita pronunciar o discurso inicial e diz, em nome de todos nós, o que melhor te parecer. Neste momento, lembra-te de todas essas qualidades e junta num só [discurso] o que disseste contra Górgias, contra Polo, contra Pródico e contra Hípias. É que este fulano é ainda mais temível. Portanto, borrifa-o com a tua ironia e atira-lhe com aquelas tuas perguntas finas e sucessivas, e, se assim te parecer bem, manda-lhe com algo como "O grande Zeus, lá no céu, guiando seu carro alado" ficaria furioso, se este fulano náo sofresse a [devida] punição.

23. PLATÃO — De modo nenhum, mas escolhamos antes alguém mais truculento, como aqui o Diógenes, ou Antístenes, ou Crates, ou mesmo tu, Crisipo. Na verdade, na presente circunstância, não é oportuno usar de beleza de estilo e elegância literária, mas sim de apetrechamento argumentativo e jurídico. É que Parresíades é um orador.

505 "prontas": O texto diz "prontos", já que um dos acompanhantes da Filosofia é o Élenkhos (que traduzi por "Refutação"), do género masculino... 
DIÓGENES - Pois bem, serei eu a acusá-lo. Na verdade, creio que náo vou precisar de um longo palavreado. De resto, eu fui ultrajado mais que todos vós, pois ainda outro dia fui posto em leiláo por dois óbolos.

PLATÃO - Diógenes, ó Filosofia, fará o discurso em nome de todos nós. E tu, meu caro, lembra-te de que, neste processo, não estás a defender somente a tua causa, mas atende à causa comum. De facto, se discordamos uns dos outros num ponto ou noutro das nossas doutrinas, náo ligues a isso, nem digas, nestas circunstâncias, qual de nós é o mais verdadeiro, mas antes enfurece-te completamente em defesa da própria Filosofia ultrajada e caluniada nas obras de Parresíades; póe de lado as nossas linhas filosóficas, nas quais discordamos [uns dos outros], e luta em favor daquilo que temos em comum. Nota bem: elegemos-te somente a ti, e de ti depende que todas as nossas doutrinas sejam consideradas respeitáveis, ou que sejam tidas tal qual este fulano as apresentou.

24. DIÓGENES - Ficai sossegados, não vos faltarei em nada. Falarei por todos. E se porventura a Filosofia, influenciada pelas suas palavras - realmente, ela é pacífica e amável por natureza—, sentenciar a sua absolvição, não lhe faltarei com a minha justiça, pois mostrar-lhe-ei que náo é em vão que uso cajado.

FILOSOFIA - Isso não, de maneira nenhuma, mas usa antes a palavra, que é melhor que o cajado. Vá lá, náo te atrases, pois a água já está a correr ${ }^{506}$, e o tribunal já tem os olhos postos em ti.

PARRESÍADES - Que os restantes se sentem, ó Filosofia, a fim de votarem convosco ${ }^{507}$. Que seja somente Diógenes a pronunciar a acusação.

FILOSOFIA - Não receias que eles votem contra ti?

PARRESÍADES - De maneira nenhuma. Pretendo ganhar a causa por uma grande maioria.

FILOSOFIA — Já é ter coragem... Sentai-vos, pois... e tu, Diógenes, começa a falar.

506 “a água já está a correr”, referência à água da clepsidra, que marcava o tempo de intervenção.

507 O júri fica, pois, constituído pela Filosofia e acompanhantes, e ainda pelos restantes filósofos — parte interessada, mas que Parresíades tem a certeza de converter à sua causa. 
25. DIÓGENES - Que espécie de homens fomos nós em vida, ó Filosofia, tu sabe-lo muitíssimo bem, pelo que não são precisas quaisquer palavras. Para já não falar da minha pessoa, quem náo conhece aqui o Pitágoras, Platão, Aristóteles, Crisipo e os demais [filósofos], e as belas doutrinas que eles produziram para a vida [humana]? Quanto aos ultrajes que este refinado patife do Parresíades cometeu contra vós, homens tão distintos, é o que passo a expor.

Tendo sido, segundo se diz, um importante orador, abandonou os tribunais e a reputação neles adquirida e, apetrechado com todo o virtuosismo e com todo o vigor oratório, tudo isso acumulou contra nós, e agora não cessa de dizer mal das nossas pessoas, chamando-nos charlatães e vigaristas e persuadindo as massas a troçarem de nós e a desprezarem-nos como pessoas sem valor. E sobretudo, fez com que nós próprios, e também tu, Filosofia, fôssemos odiados pela generalidade das pessoas, classificando de tagarelas e disparatadas as tuas doutrinas e virando para o lado da chicana as coisas sérias que tu nos ensinaste, de tal modo, que ele é aplaudido e elogiado pelos seus ouvintes, enquanto nós somos ultrajados. De facto, a multidão é assim mesmo por sua natureza, diverte-se com os que criticam e ultrajam, especialmente quando são amesquinhados os valores tidos por mais veneráveis, como certamente outrora se divertiam com Aristófanes e com Êupolis, quando estes levavam à cena aqui o Sócrates, de modo chicaneiro, compondo a seu respeito umas comédias absurdas. No entanto, aqueles [comediógrafos] atreviam-se a dizer tais coisas, mas contra um só homem isoladamente, e nas Dionísias, onde isso era tolerável, onde a chicana era considerada como fazendo parte da festa e onde

\section{talvez o deus ${ }^{508}$ se alegrasse, | por ser de indole risonha.}

26. Este fulano, porém, convoca pessoas das mais distintas e, depois de longa reflexão e longa preparação, escreve umas quantas blasfémias num grosso rolo [de papiro], e depois, com voz altissonante, diz mal de Platão, de Pitágoras, aqui do Aristóteles, ali do Crisipo, e também da minha pessoa, numa palavra, de todos nós, sem que uma festa o desculpe e sem ter pessoalmente recebido qualquer ofensa da nossa parte.

508 "o deus... de índole risonha” é Dioniso (Baco). 
Realmente, o caso seria, de algum modo, desculpável, se ele agisse em sua defesa, e não por sua iniciativa pessoal.

Mas o pior de tudo é o facto de ele, ao proceder desse modo, se abrigar sob o teu nome, Filosofia, de se insinuar no Diálogo, nosso servidor, utilizando-o contra nós como seu auxiliar e actor, e, a juntar a tudo isto, persuadiu Menipo, um nosso ${ }^{509}$ companheiro, a participar frequentemente nas suas graças de comédia; este é o único que não está aqui presente nem participa connosco na acusaçấo, deste modo traindo a nossa comunidade.

27. Por tudo isto, é justo que ele sofra uma punição. Sim, que é que ele poderia alegar, depois de ter vilipendiado o que há de mais venerando, e isto diante de tantas testemunhas? Além disso, uma tal punição seria muito proveitosa também para estas [testemunhas], se o vissem a ser castigado, para que, de hoje em diante, ninguém mais desprezasse a Filosofia. De facto, ficarmos quietinhos e suportarmos que nos ofendam seria claramente considerado um acto, não de moderação, mas sim de cobardia e de ingenuidade. Sim, quem é que pode suportar os últimos acontecimentos? Este fulano levou-nos ao mercado como escravos, arranjou um pregoeiro e pôs-nos - é o termo - em leilăo, uns por muito dinheiro, alguns por uma mina ática, a mim, o mais infame de todos ${ }^{510}$, por dois óbolos. E os espectadores, vá de rirem.

Por tudo isto é que subimos cá acima, muito indignados, solicitando-te que nos vingues por termos sido ultrajados em último grau.

28. PLATÃO - Muito bem, ó Diógenes. Disseste, e muito bem, tudo quanto convinha em favor de todos nós.

FILOSOFIA - Parem lá com os aplausos. Verte água ${ }^{511}$ para o acusado. Tu, Parresíades, toma por tua vez a palavra. Agora a água está correndo para ti. Portanto, não te atrases.

509 “nosso", ou, mais exactamente, “meu”, pois Menipo e Diógenes eram ambos filósofos cépticos.

510 “... infame...”: infame... entenda-se, na opinião atribuída por Diógenes a Parresíades...

511 "Verte água": Mais uma vez (não era preciso!), trata-se da água da clepsidra, que marca o tempo de intervenção. 
29. PARRESÍADES ${ }^{512}$ — Filosofia: Diógenes não fez contra mim uma acusação completa, mas, não sei lá porquê, omitiu pontos mais importantes e mais graves. Pela minha parte, estou muito longe de negar tudo quanto disse, ou de trazer para aqui um discurso de defesa já estudado, mas antes, se ele passou em silêncio alguns pontos, ou se eu anteriormente náo cheguei a exprimi-los, neste momento decido acrescentá-los, pois deste modo ficareis a saber que espécie de homens é que eu pus em leilão, a quem é que eu chamei charlatães e classifiquei de vigaristas. Fixai somente uma coisa: se o que eu vou dizer a seu respeito é [ou não] verdade. Se o meu discurso vos parecer conter alguma difamação ou rudeza, creio que não é a mim, seu crítico, que é mais justo acusar, mas sim aqueles que procedem desse modo.

$\mathrm{Na}$ verdade, logo que constatei quantas qualidades repugnantes precisavam de possuir os advogados - falsidade, mentira, descaramento, gritaria, altercaçóes e mil outras manhas abandonei, como era natural, essa actividade, e, tendo-me entregado, ó Filosofia, aos teus altos ideais, decidi dedicar o resto dos meus dias a viver sob a tua protecção, como se, após passar por vagas e tormentas, tivesse arribado a um porto tranquilo.

30. Mal me debrucei sobre as vossas doutrinas, logo fiquei preso de admiração por ti, como era forçoso [que assim fosse], bem como por todos esses aí, que são os legisladores da melhor forma de vida, os quais lançam a mão aos que aspiram a essa vida e lhes dão os mais belos e úteis conselhos, desde que a pessoa náo se desvie deles nem se extravie, mas, pelo contrário, estejam sempre com os olhos firmemente fixos nos princípios que vós estabelecestes, e regule e oriente a sua vida por esses [mesmos princípios] — coisa que, por Zeus!, [muito] poucos dos vossos [discípulos] ${ }^{513}$ praticam.

512 Note-se, desde já, a extensão do discurso de defesa de Parresíades (Luciano), a revelar os passados tempos da oratória forense.

513 "poucos dos vossos [discípulos]", ou, na lição dos mss. do grupo $\beta$, "poucos dos nossos [filósofos]". De facto, os mss. do grupo $\beta$ têm hèmâs "nossos", conta hümâs "vossos" (emenda moderna, de Fritzsche, seguida por G. P. Goold ("Loeb”). Recorde-se que, desde muito cedo, as letras $\eta$ e $v$ passaram a representar o mesmo fonema: [i]... 
31. Então eu, verificando que muitos, apaixonados, não pela Filosofia, mas seduzidos somente pela glória [proveniente] dessa actividade, se davam grandes ares de pessoas de bem [apenas] pelos aspectos mais superficiais, mais óbvios e mais fáceis de imitar por qualquer pessoa - refiro-me à barba, ao modo de andar e ao traçar do manto - mas, no que toca ao seu modo de vida às suas acçôes, [estavam] em contradição com o aspecto exterior e praticavam o contrário do que vós [pregais], assim desonrando a dignidade da vossa profissão, fiquei escandalizado; essa situaçáo afigurava-se-me tal e qual a de um actor de tragédia, já de si delicadinho e de aspecto feminino, a representar [o papel de] Aquiles, ou de Teseu, ou do próprio Héracles, sem o modo de andar ou de clamar próprio de um herói, mas, pelo contrário, todo amaricado, [mesmo] sob uma máscara imponente; nem mesmo Helena, nem Políxena alguma vez tolerariam serem imitadas por esses [actores] ${ }^{514}$ para lá do [tom] razoável... quanto mais Héracles, o "Glorioso Vencedor" 15 , o qual, creio bem, logo esmagaria, batendo-lhe com a sua moca, o actor mais a máscara, por ter sido tão vergonhosamente feminizado por ele.

32. Ora eu, ao ver-vos tão maltratados por esses tipos, não suportei a vergonha da representaçáo... como se eles, [que não passam de] uns macacos se atrevessem a pôr máscaras de heróis, ou a imitar o burro de Cime ${ }^{516}$, o qual, tendo envergado uma pele de leão, pretendia ser um [autêntico] leão, zurrando aos Cimenses com um som grosso e medonho, até que um estrangeiro, que já muitas vezes tinha visto um leão e um burro, o desmascarou e o perseguiu, espancando-o à paulada.

Mas, ó Filosofia, o que me pareceu particularmente escandaloso foi o facto seguinte: Sempre que as [outras] pessoas viam um destes cometer algum acto perverso, vergonhoso ou indecente, não faltava quem acusasse a própria Filosofia e, logo a seguir, Crisipo, ou Platão, ou Pitágoras, ou qualquer outro, de cujo nome esse prevaricador se reivindicava e cujas

${ }^{514}$ Recorde-se que os papéis femininos eram representados por homens...

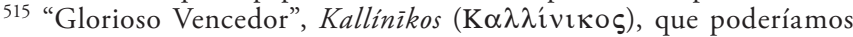
adaptar em port.: Calinico.

${ }^{516}$ Cime, cidade da Eólide (Ásia Menor); nome de outras cidades. 
palavras imitava ${ }^{517}$. Então, a julgar por esse tal, que levava uma vida vergonhosa, pensavam mal de vós [todos], há muito tempo mortos. De facto, a apreciação feita a essa pessoa não se fazia por comparação convosco na situação de vivos, pois vós estáveis bem longe dali, ao passo que todos viam claramente esse fulano a praticar actos horrendos e indignos, de modo que, sem estardes presentes, éreis misturados com esse fulano e arrastados na mesma acusação.

33. Ao ver tal coisa, não me contive, pelo que passei a desmascará-los e a distingui-los de vós. Vós, porém, em vez de me honrardes por essa minha actividade, trazeis-me aqui ao tribunal. Pois bem: Se eu, ao ver um iniciado a revelar os mistérios das duas Deusas ${ }^{518}$ e a dançar fora [do recinto sagrado], me indignasse e o acusasse, seria a mim que vós consideraríeis ímpio? Não seria justo. Do mesmo modo, os atlótetas $^{519}$ costumam [mandar] chicotear todo o actor que, ao fazer o papel de Atena, ou de Posídon, ou de Zeus, náo o representam convenientemente nem de acordo com a dignidade desses deuses, e estes náo se zangam mesmo nada com eles pelo facto de ordenarem aos mastigóforos ${ }^{520}$ que açoitem aquele que enverga a sua máscara e o seu vestuário, mas até ficariam — julgo eu - muito satisfeitos, se eles fossem ainda mais açoitados. Na verdade, seria pequena falta representar menos dignamente um servo ou um mensageiro, mas mostrar aos espectadores um Zeus ou um Héracles sem a devida dignidade... que sacrilégio infame!

34. Mas o mais absurdo de tudo isto é o facto de, na sua grande maioria, conhecerem a fundo as vossas obras, mas

517 “imitava”, emimeîto (દ่ $\mu \imath \mu \varepsilon \hat{\imath} \tau o$ ) é emenda moderna (Seager), não

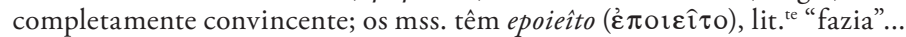
"(re)produzia". A emenda moderna é aquilo a que se chama uma lectio facilior, uma "lição mais fácil", a qual, quando consta dos manuscritos, é geralmente tida como emenda de copista ou comentador, que passou para o texto, substituindo a lectio difficilior, a "lição mais difícil"... provavelmente a mais fidedigna.

518 “duas Deusas”, ou seja, Deméter e Perséfone.

519 “atlótetas" ou "agonótetas” são os magistrados que presidem aos jogos ou festivais, ou desempenham a função de juízes.

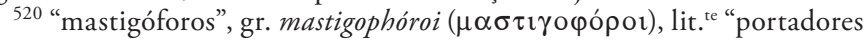
de chicote", eram os... "polícias de segurança pública". 
como se as lessem e estudassem com uma única finalidade: procederem ao invés e viverem em conformidade com isso. De facto, o livro afirma que devemos desprezar as riquezas ${ }^{521}$ e a glória, e considerar bom somente aquilo que é belo, ser imune à ira, desdenhar das pessoas importantes e conversar com elas em pé de igualdade, dizendo ${ }^{522}$, pois, ó deuses!, coisas na verdade muito belas, muito sábias e muito admiráveis. Esses fulanos, porém, ensinam tais doutrinas por dinheiro, ficam extasiados perante os ricos, embasbacados com o dinheiro, mais irritadiços que os cachorrinhos, mas mais cobardes que as lebres, mais bajuladores que os macacos, mais impudentes que os burros, mais ladróes que os gatos e mais agressivos que os galos. Por isso, caem no ridículo, quando se guerreiam por essas coisas, se acotovelam uns aos outros à porta dos ricos, quando participam em jantares muito concorridos e aí se desfazem grosseiramente em elogios, se empanturram para lá do que é decente, se queixam abertamente de serem mal servidos, filosofam de modo enfadonho e incoerente enquanto bebem, sem aguentarem o vinho puro ${ }^{523}$. Todavia, todos os leigos [na matéria] aí presentes se riem deles, naturalmente, e escarnecem duma filosofia que produz uma tal escumalha.

35. O mais vergonhoso de tudo, porém, é que cada um deles, embora afirmando que náo necessita de nada e clamando que só o sábio é rico, logo a seguir vai mendigar, e irrita-se por não receber, semelhante a alguém que, envergando vestes reais, com uma tiara alta, um diadema e todas as demais insígnias da realeza, fosse mendigar, pedindo [esmola] aos mais necessitados.

Quando se trata de receber alguma coisa, fazem uma longa dissertação sobre aquilo que deve ser comum a todos, dizendo que a riqueza é coisa indiferente ${ }^{524}$, e ainda: "Que é o ouro, ou

521 "o livro diz que devem desprezar as riquezas" é a lição dos mss. do grupo $\beta$, aceite por alguns modernos editores ("Loeb”...), ao passo que os mss. do grupo $\gamma$ dizem: "tudo o que dizem, como sobre o desprezo das riquezas...".

522 "dizendo": o sujeito é "o livro" (v. supra); na outra leitura, temos a sequência: "afirmam (eles)... ..., dizendo (eles)".

523 "vinho puro": Normalmente, o vinho era servido misturado com água, em partes variáveis. Só os beberróes é que o bebiam puro. Diz Horácio. Adde merum..., "chega-lhe do puro...".

524 "indiferente" é um termo da doutrina estóica. V. $\$ 21$, notas aos termos indiferentes e preferiveis. 
a prata, que em nada diferem dos seixos da praia?" Mas quando algum companheiro ou amigo de longa data vem ter com eles e lhes pede um pouco do muito [que eles têm], [só encontra] silêncio, dificuldades, falta de lembrança ${ }^{525}$ e transtornarão das doutrinas em sentido contrário. Os muitos e famosos discursos sobre a amizade, a virtude, o belo, tudo isso vai voando náo sei lá para onde, autênticas "palavras aladas" 526 , todos os dias por eles esgrimidas nas suas aulas.

36. Na verdade, qualquer um pode ser seu amigo, desde que não se trate de questôes de ouro ou prata; mas basta que alguém lhes acene com um óbolo, logo se quebra a paz, é uma guerra total sem tréguas e não declarada; os livros são apagados e a Virtude póe-se em fuga. Então procedem como os cães, quando alguém lhes atira com um osso: saltam-lhe em cima, mordem-se uns aos outros e ladram contra aquele que foi o primeiro a apanhá-lo.

Diz-se que certo rei egípcio ensinou uns macacos a dançar $^{527}$ a dança pírrica ${ }^{528}$, e que os animais — que são os mais capazes de imitar os gestos humanos - aprenderam muito rapidamente, dançando vestidos de púrpura e com máscaras, pelo que durante muito tempo o espectáculo foi do agrado [das pessoas]... até que um espectador mais divertido, que trazia umas nozes no seio, as atirou para o meio [da cena]. Então os macacos, ao verem [as nozes], esqueceram-se da dança e transformaram-se naquilo que [realmente] eram — macacos -, em vez de dançarinos, fizeram as máscaras em pedaços, rasgaram as vestes e começaram a lutar uns com os outros pelos frutos; estava desfeita a boa ordem da dança, o que foi motivo de risota da assistência.

37. É isso mesmo que esses fulanos fazem, e é deles que eu digo mal, e nunca deixarei de os desmascarar e de os pôr a ridículo. E no que concerne às vossas pessoas ou àqueles que

525 "falta de lembrança", ou seja, faz que não se lembra dos tempos antigos e da velha amizade...

526 "palavras aladas" é expressão homérica muito repetida nos poemas.

${ }^{527}$ Ver Apologia dos Assalariados dos Grandes, $\$$ 5, onde se refere somente um macaco, pertencente a Cleópatra.

${ }^{528}$ Tratava-se de uma dança guerreira, em que dois adversários representavam o atacante e o defensor. Com o tempo, o termo pôde aplicar-se a outros tipos de dança... 
vos estão próximos — na verdade, há homens desses, que cultivam verdadeiramente a filosofia e se conformam com os vossos preceitos —, eu não seria táo louco, a ponto de dizer a seu respeito fosse o que fosse de blasfemo ou de grosseiro. E que poderia eu dizer? Será que vós levastes uma tal vida? Pois eu considero que é justo odiar esses charlatães e inimigos dos deuses. Tu, ó Pitágoras, e tu, Platão, e tu, Crisipo, e tu, Aristóteles, que dizeis a isto? Será que tipos desta laia têm alguma coisa que ver convosco, ou que, no seu modo de vida, revelam alguma familiaridade ou afinidade convosco? Por Zeus!, é - como sói dizer-se - "[comparar] Héracles com um macaco". Ou será que, só pelo facto de usarem barba [comprida], de se gabarem de filosofar e de terem um aspecto sisudo, já devem ser comparados convosco? Ora, eu ainda os suportaria, se eles fossem convincentes nessa sua representaçáo. No caso presente, porém, seria mais fácil que um abutre imitasse um rouxinol, que esses fulanos imitarem filósofos.

Tenho dito, em minha defesa, o que tinha para dizer. Agora tu, ó Verdade, testemunha perante os juízes se eu disse a verdade.

38. FILOSOFIA - Afasta-te, Parresíades... afasta-te mais... E nós que faremos? Como vos pareceu o que o homem acaba de dizer?

VERDADE - Por mim, ó Filosofia, enquanto ele falava, eu antes queria estar debaixo da terra, de tal modo o homem falou verdade. De facto, à medida que o escutava, ia reconhecendo cada um dos que assim procediam e aplicava-o ao que estava a ser dito: isto aplica-se a este [tipo], aquilo é o que diz fulano... numa palavra, mostrou-nos esses homens com toda a clareza, como se completamente pintados numa tela, e representados com a maior fidelidade, não somente no que respeita aos corpos, mas também no que respeita às almas.

VIRTUDE - Eu, a Virtude, também corei bastante.

FILOSOFIA - E vós aí, que dizeis?

PLATÃO $^{529}$ - Que dizer, senão que devemos absolvê-lo da acusação e incluí-lo na lista dos nossos amigos e benfeitores? Passou-se connosco exactamente o mesmo que com os Troianos; de facto, fizemos vir aqui este "actor trágico", para

${ }^{529}$ Alguns editores atribuem esta fala aos RESSUSCITADOS, como se fosse uma resposta em coro. Tanto faz... 
que nos cantasse as desgraças da Frígia. Deixá-lo, pois, cantar e representar uma tragédia contra os inimigos dos deuses.

DIÓGENES - Também eu, ó Filosofia, faço os maiores elogios ao homem, retiro a minha acusação e faço deste valente um amigo.

39. FILOSOFIA - Muito bem. Avança, Parresíades. Absolvemos-te da acusação; ganhaste por unanimidade, e fica sabendo que, de hoje em diante, és cá dos nossos.

PARRESÍADES - Fiz a minha oração no princípio ${ }^{530}$; agora, porém, acho que devo dizer algo mais trágico, pois é mais solene:

Ó mui venerável Nice, enche toda a minha vida, não deixes de coroar-me.

VIRTUDE - Pois bem, demos já início à segunda libação ${ }^{531}$. Chamemos aqueles outros, para serem punidos pelas ofensas que nos têm feito. Parresíades acusá-los-á um por um.

FILOSOFIA - Disseste muito bem, ó Virtude. Portanto, tu, Silogismo, debruça-te sobre a cidade e convoca os filósofos.

40. SILOGISMO - Escutai! Silêncio! Que os filósofos se dirijam à Acrópole, a fim de se justificarem perante a Virtude, a Filosofia e a Justiça.

PARRESÍADES - Estás vendo? São muito poucos os que tomaram conhecimento da proclamação e sobem até cá acima; aliás, temem a Justiça. Na sua grande maioria, não têm vagar, pois estão na companhia dos ricos. Mas se queres que todos eles se apresentem, ó Silogismo, apregoa mais ou menos assim: ... ${ }^{532}$

SILOGISMO ${ }^{533}$ — De maneira nenhuma, ó Parresíades, mas chama-os antes tu, da forma de melhor te parecer.

${ }^{530}$ V. $\$ 21$, em que invoca [Atena] Políade, "Protectora da Cidade"; agora vai invocar [Atena] Nikē a "Vitória".

531 "segunda libação": o texto diz "segunda cratera" [de vinho]. Trata-se de dar início ao segundo julgamento, o dos maus filósofos...

532 Aqui o Silogismo sugere que seja o próprio Parresíades a fazer a proclamaçáo, em vez de apenas exemplificar...

${ }^{53}$ Ao contrário de outros editores, que atribuem esta fala à Filosofia, o editor da "Loeb" atribui-a ao Silogismo. Tanto faz... 
41. PARRESÍADES - Não é coisa nada difícil: Escutai! Silêncio! Todos quantos se têm na conta de filósofos e todos quantos pensam que essa designação lhes assenta bem, que subam aqui à Acrópole, para uma distribuição. Serão dadas duas minas a cada um, e ainda um bolo de sésamo. Todo aquele que apresentar uma barba farfalhuda, receberá, como suplemento, uma cesta de passas de figo. Não é preciso que cada um traga consigo nem bom senso, nem justiça, nem moderação. Na verdade, se não tiverdes essas qualidades, elas também não são necessárias. Deveis trazer, sem falta, cinco silogismos, pois sem eles não é permitido ser filósofo.

Eis também, nesse conjunto, | estes dois talentos ${ }^{534}$ de ouro, pra dar a quem, de entre todos, | sobressair no debate. ${ }^{535}$

FILOSOFIA ${ }^{536}$ — Ah! Quanta gente! A colina está pejada de pessoas que se acotovelam pelas duas minas, mal ouviram falar delas. Uns vêm dos lados do Pelásgico, outros das bandas do templo de Asclépio, muitos mais, da zona do Areópago, alguns dos lados do túmulo de Talo ${ }^{537}$, outros ainda, encostando escadas ao templo dos Dioscuros ${ }^{538}$, sobem [pelo muro], zumbindo, por Zeus!, e em cachos à maneira de um enxame [de abelhas], para citar Homero... Vêm muitos daquele lado, e do outros muitos mais:

São aos milhares, como as folhas $\mid e$ as flores na Primavera ${ }^{539}$.

Em pouco tempo, a Acrópole vai estar cheia de homens que se sentam ruidosamente; por toda a parte, [só se vêem] alforges e bajulação, barbas e impudor, cajados e gulodice, silogismos

${ }^{534} \mathrm{O}$ talento não era uma moeda propriamente dita, mas uma «moeda de conto" (cf. contos de réis) = 60 minas; uma mina = 100 dracmas; uma dracma $=6$ óbolos. Portanto, um talento $=6.000$ dracmas. Aqui, dois talentos = 120 minas ou 12.000 dracmas. Noutros contextos, o termo talento podia referir-se, de maneira indeterminada, àquilo que designamos por "um balúrdio».

535 Iliada, XVIII, 507-508.

536 Alguns mss. e editores modernos continuam a atribuir a fala a Parresíades. O editor da "Loeb" entende que há mudança de interveniente.

${ }^{537}$ Este Talo (havia outro, mais conhecido) era um ateniense, sobrinho de Dédalo, etc., etc...

538 Templo dos Dioscuros (Castor e Pólux), também denominado Anákeion ('Avó кєı๐), que daria em port. Anaceu.

539 Iliada, II, 468. 
e avareza. Os poucos que acorreram à primeira proclamação estâo invisíveis e nem se notam; misturados com a multidão dos outros, passam despercebidos devido à similitude do aspecto exterior.

PARRESÍADES - Mas, ó Filosofia, o pior de tudo, aquilo por que mais te poderíamos censurar, é o facto de tu ainda náo lhes teres imposto uma marca ou um sinal. $\mathrm{Na}$ verdade, estes charlatães são, muitas vezes, mais convincentes que os verdadeiros filósofos.

FILOSOFIA - Assim se fará em breve... Mas agora recebamo-los.

43. PLATÓNICO — Pertence-nos a nós, Platónicos, sermos recebidos em primeiro lugar.

PITAGÓRICO — Isso é que não, mas antes a nós, Pitagóricos, pois Pitágoras é anterior [a vós].

ESTÓICO — Estais doidos! Nós, os do Pórtico, somos superiores.

PERIPATÉTICO - De maneira nenhuma, já que, em questóes de dinheiro, nós, os Peripatéticos, devíamos ser os primeiros.

EPICURISTA - A nós, os Epicuristas, dai-nos os bolos e as passas de figo; quanto às minas, aguardamos, mesmo que sejamos os últimos a recebê-las.

ACADÉMICO - Onde estão os dois talentos? Sim, nós, os Académicos, mostraremos como somos os mais aguerridos de todos...

ESTÓICO — ... Mas não quando os Estóicos estão presentes.

44. FILOSOFIA - Deixem-se de discussões. E vós, os Cínicos, não se atirem uns contra os outros nem se batam com os cajados. Na verdade, ficai sabendo que foi por outro motivo que vós fostes convocados. Agora, eu, Filosofia, bem como aqui a Virtude e a Verdade, vamos julgar quem é que são os verdadeiros filósofos. Seguidamente, todos quantos forem considerados como vivendo segundo os nossos preceitos, serão felizes e julgados pessoas superiores, ao passo que, no que respeita aos charlatães que nada têm que ver connosco, esmagá-los-emos miseravelmente, como miseráveis que são, para que não se façam passar por mais do que são - uns impostores... Mas... que vem a ser isto? Já fugis? Sim, por Zeus!, 
e muitos deles saltando mesmo pelas ribanceiras. A Acrópole ficou vazia, com excepção de uns quantos, muito poucos, que ficaram, sem temerem o julgamento...

45. ... Vós aí, funcionários, apanhai o alforge que o Cínico largou ao fugir... Vejamos que é que tem dentro... provavelmente tremoços, ou um livro, ou pães de trigo.

FUNCIONÁRIO ${ }^{540}$ - Nada disso, mas antes ouro — cá está ele -, e perfume, e uma navalha de barba ${ }^{541}$, e um espelho, e dados.

FILOSOFIA - Muito bem, meu caro ${ }^{542}$. Eram então estes os apetrechos da tua profissão?! ${ }^{43}$ Era com eles que pretendias fazer pouco de toda a gente e educar as outras pessoas?!

PARRESÍADES - É assim que eles são todos. E vós deveis estudar a maneira de acabar com estes erros e de fazer com que os que contactam com eles saibam distinguir, entre eles, os que são honestos daqueles que levam uma vida diferente [das suas doutrinas].

FILOSOFIA ${ }^{544}$ - Tu, ó Verdade, trata de descobrir [essa maneira], pois isso parece ser do teu interesse, ou seja, fazer que a Mentira não prevaleça sobre ti e que, por acção da Ignorância, os maus não te passem despercebidos, ao imitarem os bons.

46. VERDADE - Se vos aprouver, confiemos essa tarefa ao próprio Parresíades, pois ele é considerado uma pessoa honesta, que simpatiza connosco e que, de um modo especial, te

${ }^{540}$ Interpretação do editor da "Loeb"; outros atribuem a fala a Parresíades.


$\tau \imath \kappa o ́ v)$ é emenda do editor da "Loeb"; du Soul emenda para makhairion

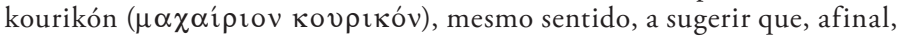
o cínico, em ocasiôes especiais (banquetes em casa dos ricos) cuidava da sua apresentaçẫo capilar (v. logo a seguir a referência ao espelho); "makhaírion thütikón ( $\mu \alpha \chi \alpha$ ípıov $\theta v \tau \imath \kappa o ́ v)$ "navalha dos sacrifícios" é a lição de alguns mss.; Esta lição (afinal antiga!) sugere que o Cínico andava apetrechado com uma navalha, que lhe servia para aproveitar a carne das vítimas de um sacrifício... Enfim, é difícil optar por uma das interpretaçôes em detrimento da outra, mas a referência a apetrechos nada consentâneos com a doutrina cínica funciona como uma crítica aos falsos filósofos...

542 "meu caro": Refere-se, não ao funcionário, mas ao Cínico, que imaginamos já ir lá longe...

543 áskèsis (ő $\sigma \kappa \eta \sigma i \varsigma)$ "profissão", "exercitação", "prática”, mas também "ascese", donde "mortificação"...

${ }^{544}$ Alguns editores continuam a atribuir esta fala a Parresíades... 
admira a ti, Filosofia; que ele tome consigo a Averiguação ${ }^{545}$, e que esta vá procurar todos quantos se gabam de filosofar; no caso de encontrar alguém que seja mesmo um filósofo genuíno, deve coroá-lo com uma coroa de ramo de oliveira e chamá-lo ao Pritaneu ${ }^{546}$; mas se encontrar algum execrando impostor da filosofia - e há muitos assim —, que, depois de lhe espatifar o manto, com a faca de tosquiar bodes, lhe rape a barba rentinha à pele e lhe imprima uma marca, ou na fronte, ou então, com um ferro em brasa, entre as sobrancelhas; a matriz do ferro deve ser uma raposa ou um macaco.

FILOSOFIA - Dizes muito bem, ó Verdade. Façamos um teste, como se diz das águias relativamente ao sol $^{547}$, não porém, por Zeus!, fazendo-os olhar directamente a luz [do sol] e pondo-os á prova desse modo, mas, tendo-lhes posto na frente ouro, glória e prazer, aquele que tu vires que despreza [essas coisas] e não se deixa seduzir ao vê-las, que esse seja coroado com um ramo de oliveira; mas todo aquele que olhar fixamente e estender a mão para o ouro, deves arrastá-lo para o ferro em brasa, mas primeiro rapa-lhe a barba, conforme foi decidido.

47. PARRESÍADES - Assim seja feito, ó Filosofia; brevemente verás muitíssimos desses tipos trazendo na testa a marca da raposa ou do macaco, e muito poucos coroados. Mas, com tua licença, vou trazer-vos cá para cima alguns desses tais.

FILOSOFIA - Como dizes? Vais trazer cá para cima os fugitivos?

545 "Averiguação": O termo élenkhos (๕̌n $\varepsilon \gamma \chi 0 \varsigma)$ é diversamente traduzido, p. ex., ingl. Investigation ("Loeb”), fr. Conviction, etc.; pode também significar "o acto de provar sem margem de dúvida, desmentindo o interlocutor", ou "refutação certa e segura"; etc... Note que, no resto da fala, o sujeito é a Averiguação, e não a Filosofia, como se vê (no texto grego) por um particípio aoristo ("depois de lhe espatifar...", ou "tendo-lhe espatifado"): perispásas ( $\pi \varepsilon \rho \imath \sigma \pi \alpha ́ \alpha \alpha \varsigma)$, a concordar com Élenkhos ("E $\lambda \varepsilon \gamma-$ $\chi 0 \varsigma)$... do género masculino, mas que tive de traduzir por um feminino: "Averiguação"...

${ }^{546} \mathrm{O}$ Pritaneu era um edifício do Estado, onde eram recebidos os hóspedes ilustres e, nomeadamente, eram alimentados os benfeitores da cidade. A expressão comer no Pritaneu significava "comer a expensas do Estado”. O poeta trágico, e beberrão, Cratino, na piada de Aristófanes, achava que, pelo bem que havia feito à cidade, merecia beber (!!!) no Pritaneu, ou seja, beber a expensas do Estado...

547 Crê-se que as águias são capazes de fixar directamente o sol, e que expóem os filhotes a essa prova, para verem se eles são águias completas. 
PARRESÍADES - Com certeza, desde que a sacerdotisa esteja disposta a emprestar-me por algum tempo a linha de pesca e o anzol que lhe ofereceu o tal pescador do Pireu.

SACERDOTISA - Ei-los, toma lá, e também a cana, para teres tudo [o que é preciso].

PARRESÍADES - Agora, ó sacerdotisa, dá-me cá também, e depressa, algumas passas de figo e um pouco de ouro.

SACERDOTISA - Toma lá.

FILOSOFIA — Que é que o homem tenciona fazer? ${ }^{358}$ Iscou o anzol com uma passa de figo e com ouro, sentou-se no alto da muralha e lançou-o até lá abaixo à cidade... Que é que estás fazendo, ó Parresíades? Será que pretendes pescar pedras lá de baixo do Pelásgico? ${ }^{349}$

PARRESÍADES - Cala-te, Filosofia, e espera pela pescaria. E tu, Posídon Pescador, e tu também, querida Afrodite, manda-nos uma grande quantidade desses peixes... Mas... avisto um corpulento lúcio ${ }^{550}$, ou melhor, uma dourada ${ }^{551} \ldots$ Não... é antes um peixe-gato ${ }^{552}$. Ei-lo que se aproxima do anzol, de boca escancarada... já farejou o ouro... já está muito perto... mordeu [o isco]... já está apanhado. Puxemos. Puxa também tu, ó Averiguação $0^{553}$... [Averiguação, ${ }^{554}$ ] ajuda-me a segurar a linha.

AVERIGUAÇĀO - Já está cá em cima. Ora vejamos: Quem és tu, belíssimo peixe? ... Mas... é mesmo um cão 555 ! Por Hércules!, que dentes! Que é isto, meu caro? Deixaste-te

${ }^{548}$ Alguns editores atribuem o resto da fala à Sacerdotisa, como se esta respondesse à pergunta da Filosofia; Na minha (e de outros) interpretaçáo, a Filosofia faz a pergunta e ela própria responde. Tanto faz...

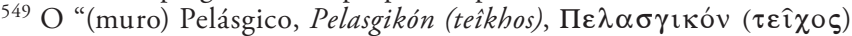
era a muralha da cidadela do lado Noroeste de Atenas; aqui significa, mais exactamente, a parte de fora, pedregosa e já no campo, desse lado da muralha.

${ }^{550}$ gr. lábrax $(\lambda \alpha \dot{\beta} \rho \alpha \xi)$ tem sido interpretado quer como "lúcio" (peixe de água doce, muito voraz), quer como "lobo-do-mar". Tenho dificuldade de decidir...

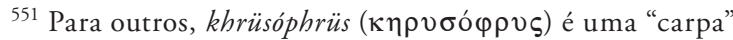

552 O nome, a aparência ou o "temperamento" destes peixes são muito

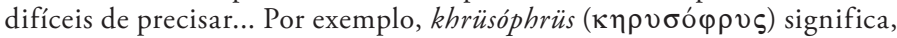
lit. ${ }^{\text {te }}$ " "de sobrancelhas douradas", que bem poderia ser uma referência a algum desses supostos filósofos, de ruivas, grossa e arqueadas sobrancelhas...

553 "Averiguação": v. nota, $\$ 46$.

${ }^{554}$ Esta repetição é muito suspeita, e, de facto, não consta dos mss. $\beta$.

555 "cão", "peixe-cão", mas, afinal um autêntico cão, ou seja, num sentido admitido pelos próprios cínicos, um... cínico. 
apanhar, enquanto andavas a lamber as rochas, onde esperavas esconder-te para passares despercebido?! Pois agora vais ficar aqui à vista de toda a gente, pendurado pelas "guelras" 556 ... Ora entâo retiremos o anzol e o isco... Por Zeus!, engoliu-o! Olha aqui para o anzol sem nada. A esta hora, a passa de figo e o ouro já se encontram na sua barriga.

PARRESÍADES — Por Zeus!, fá-lo vomitar, a fim de pormos o isco para outros... Muito bem... Que dizes, ó Diógenes? Sabes quem é este fulano? Terá alguma coisa a ver contigo?

DIÓGENES - Absolutamente nada.

PARRESÍADES - Então? Quanto é que diremos que ele vale? Outro dia avaliei-o em dois óbolos.

DIÓGENES - Isso é muito, pois o tipo é intragável, fétido ${ }^{557}$, duríssimo... não vale nada. Lança-o de cabeça contra o rochedo... Vá, lança o anzol e iça outro, mas toma cuidado, Parresíades, para que a cana não se dobre demasiado e se quebre.

PARRESÍADES — Sossega, Diógenes, pois eles são muito leves, menos pesados que petingas ${ }^{558}$.

DIÓGENES — Sim, por Zeus!, são mesmo pequenotes. Mesmo assim, puxa-os cá para cima.

49. PARRESÍADES - Eis que se aproxima outro, espalmado, como se fosse só meio peixe. uma espécie de linguado ${ }^{559}$, de boca escancarada apontada ao anzol... Engoliu-o, está apanhado, puxa-o cá para cima... Quem é ele?

AVERIGUAÇÃO - É um que diz ser Platónico.

PARRESÍADES - Também tu, meu maldito, vens ao [cheiro do] ouro?... Que é que dizes, ó Platão? Que faremos dele?

50. PLATÃO - Atira-o também contra a mesma rocha... Lança [o anzol] para outro.

556 "guelras": Aplicado ao cínico, sugere fortemente "(pendurado pelas) orelhas", ou "... pelo pescoço"...

557 "fétido", gr, eidekhthés ( $\varepsilon i \delta \varepsilon \chi \theta \eta ் \varsigma)$, também pode significar "feio", "(de aspecto) horrendo"...

558 "petingas" ou outro peixe muito pequeno; no texto, pretende-se

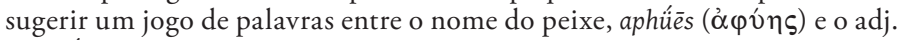

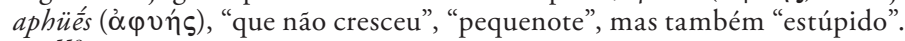

559 "linguado": Pode náo se tratar propriamente de "linguado”, mas de outro peixe espalmado; em todo o caso, o adj. hüpóplatos (ن́ $\pi$ ó $\pi \lambda \alpha \tau o \varsigma$ )

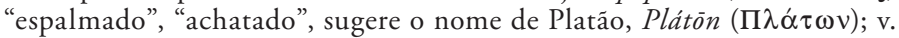
a seguir. 
PARRESÍADES - Estou a ver avançar um muito vistoso... tanto quanto parece à profundidade em que está..., de cor de pele garrida, com uma espécie de fitas douradas no lombo. Estás vendo, ó Averiguação?

AVERIGUAÇÃO - O tipo imita a maneira de Aristóteles.

PARRESÍADES - Aí vem ele... depois afasta-se... observa tudo muito bem à sua volta... regressa aqui... escancarou a boca... está apanhado. Puxa-o cá para cima.

ARISTÓTELES - Ó Parresíades, não me perguntes nada sobre o fulano, pois não sei quem ele é.

PARRESÍADES - Portanto, ó Aristóteles, às rochas com o tipo...

51. ... Olha para ali ${ }^{560}$, estou vendo uma grande quantidade de peixes, todos da mesma cor, com espinhos e o corpo todo eriçado, mais difíceis de apanhar que ouriços ${ }^{561}$. Será necessária uma rede para os apanhar?

FILOSOFIA — ${ }^{562}$ Mas não temos rede... Mas basta trazer cá acima um [exemplar] do cardume. Certamente que virá ao anzol aquele que for o mais atrevido de todos.

AVERIGUAÇÃO — Lança [o anzol], por favor, mas primeiro envolve bem a linha com arame, para que ele não a corte com os dentes, ao engolir o ouro.

PARRESÍADES - Já está lançado. Agora tu, Posídon, proporciona-me uma pesca rápida... Oh! Até se brigam por causa do isco, uns - aos magotes e em maior número - debicam a passa de figo; outros atiram-se furiosamente ao ouro. Muito bem! Um deles, muito forte, já ficou preso [no anzol]. Ora vejamos: De quem é que te afirmas epónimo?53 ... Mas que ridículo que eu sou, ao obrigar um peixe a falar! Sim, eles são mudos... Mas tu, Averiguação, diz-me cá quem é o seu mestre. AVERIGUAÇÃO — É aqui o Crisipo.

${ }^{560}$ Alguns editores atribuem a fala deste período, não a Parresíades, mas a Diógenes.

${ }^{561}$ Referência aos estóicos e à sua doutrina muito complicada e difícil de entender.

562 Alguns editores não mudam de interveniente.

563 “epónimo", não o nome próprio da pessoa, mas, neste caso, do chefe da escola filosófica (Crisipo, chefe do Estoicismo). 
PARRESÍADES - Compreendo. É que, julgo eu, havia ouro no seu nome ${ }^{564}$. Tu, ó Crisipo, diz-me cá, por Atena!, se conheces estes homens ou se os aconselhas a proceder desse modo ${ }^{565}$.

CRISIPO - Por Zeus!, ó Parresíades, fazes-me uma pergunta injuriosa, ao sugerires que estes tipos têm alguma coisa que ver connosco.

PARRESÍADES - Muito bem, Crisipo, és um homem de carácter. Quanto a este fulano, [lancemo-lo] também a ele de cabeça, a juntar-se aos outros... mas, como é muito espinhoso $^{566}$, receio que alguém, ao tentar comê-lo, fure a garganta.

52. FILOSOFIA - Basta de pescaria, Parresíades, não se dê o caso de algum deles - e muitos são capazes disso - arrebatar o ouro juntamente com o anzol e pôr-se em fuga... e depois tu é que terias de pagar à sacerdotisa ${ }^{567}$. Portanto, nós vamo-nos daqui embora ${ }^{568}$, para darmos um passeio; $r$ quanto a vós, é tempo de irdes para donde viestes, para não ultrapassardes o prazo [que vos foi concedido]... E agora vós os dois, tu, Parresíades, mais a Averiguação, ide fazer a ronda por todos esses tipos e, conforme eu disse, coroai-os ou marcai-os com um ferro em brasa ${ }^{569}$.

PARRESÍADES - Assim se fará, Filosofia. Adeus, meus bons senhores... Nós, ó Averiguação, desçamos e executemos as ordens recebidas.

AVERIGUAÇÃO - Aonde devemos dirigir-nos em primeiro lugar? À Ácademia? Ou ao Pórtico? Ou começaremos a partir do Liceu?

PARRESÍADES - Tanto faz. O que eu sei é que, aonde quer que nos dirigirmos, precisaremos de poucas coroas, mas de muitos ferros em brasa ${ }^{570}$.

${ }^{564} \mathrm{O}$ nome Crisipo é um composto, cujo $1^{\circ}$ elemento é khrüsós ( $\chi \rho v \sigma o ́ \varsigma$ ), “ouro" (o 2o elemento é híppos (i $\pi \pi \mathrm{\sigma} \varsigma$ ), "cavalo").

$565 \mathrm{Ou}$ seja, apegados ao ouro, às riquezas...

566 "espinhoso": Referência aos sofismas e silogismos arrevesados dos estóicos, difíceis de entender e de refutar.

567 Cf. $\$ 47,2^{\text {a }}$ fala de Parresíades.

568 "nós vamo-nos embora" é um plural majestático, referido à Filosofia e aos seus acompanhantes, por oposição (como se vê logo a seguir) aos filósofos que vieram do Hades, e que para lá deveriam regressar.

569 Cf. $\$ 46$, início, fala da Verdade.

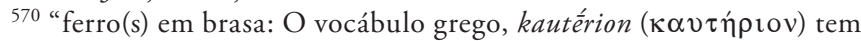
correspondência perfeita em port.: cautério, que bem poderíamos utilizar... até com um forte sentido técnico... 


\section{Volumes publicados na ColecÇão Autores Gregos e Latinos - Série Textos Gregos}

1. Delfim F. Leão e Maria do Céu Fialho: Plutarco. Vidas Paralelas - Teseu e Rómulo. Tradução do grego, introdução e notas (Coimbra, CECH, 2008).

2. Delfim F. Leão: Plutarco. Obras Morais - O banquete dos Sete Sábios. Tradução do grego, introduçáo e notas (Coimbra, $\mathrm{CECH}, 2008)$.

3. Ana Elias Pinheiro: Xenofonte. Banquete, Apologia de Sócrates. Tradução do grego, introdução e notas (Coimbra, CECH, 2008).

4. Carlos de Jesus, José Luís Brandão, Martinho Soares, Rodolfo Lopes: Plutarco. Obras Morais - No Banquete I - Livros $I-I V$. Tradução do grego, introdução e notas. Coordenação de José Ribeiro Ferreira (Coimbra, CECH, 2008).

5. Ália Rodrigues, Ana Elias Pinheiro, Ândrea Seiça, Carlos de Jesus, José Ribeiro Ferreira: Plutarco. Obras Morais - No Banquete II - Livros V-IX. Tradução do grego, introdução e notas. Coordenação de José Ribeiro Ferreira (Coimbra, $\mathrm{CECH}, 2008)$.

6. Joaquim Pinheiro: Plutarco. Obras Morais - Da Educação das Crianças. Tradução do grego, introdução e notas (Coimbra, $\mathrm{CECH}, 2008)$.

7. Ana Elias Pinheiro: Xenofonte. Memoráveis. Tradução do grego, introdução e notas (Coimbra, CECH, 2009).

8. Carlos de Jesus: Plutarco. Obras Morais - Diálogo sobre o Amor, Relatos de Amor. Tradução do grego, introdução e notas (Coimbra, CECH, 2009).

9. Ana Maria Guedes Ferreira e Ália Rosa Conceição Rodrigues: Plutarco. Vidas Paralelas - Péricles e Fábio Máximo. Tradução do grego, introdução e notas (Coimbra, CECH, 2010).

10. Paula Barata Dias: Plutarco. Obras Morais - Como Distinguir um Adulador de um Amigo, Como Retirar Benefício dos Inimigos, Acerca do Número Excessivo de Amigos. Tradução do grego, introduçáo e notas (Coimbra, CECH, 2010). 
11. Bernardo Mota: Plutarco. Obras Morais - Sobre a Face Visivel no Orbe da Lua. Tradução do grego, introdução e notas (Coimbra, CECH, 2010).

12. J. A. Segurado e Campos: Licurgo. Oração Contra Leócrates. Tradução do grego, introdução e notas (Coimbra, CECH /CEC, 2010).

13. Carmen Soares e Roosevelt Rocha: Plutarco. Obras Morais - Sobre o Afecto aos Filhos, Sobre a Música. Tradução do grego, introdução e notas (Coimbra, CECH, 2010).

14. José Luís Lopes Brandão: Plutarco. Vidas de Galba e Otão. Tradução do grego, introdução e notas (Coimbra, CECH, 2010).

15. Marta Várzeas: Plutarco. Vidas de Demóstenes e Cícero. Tradução do grego, introdução e notas (Coimbra, CECH, 2010).

16. Maria do Céu Fialho e Nuno Simóes Rodrigues: Plutarco. Vidas de Alcibiades e Coriolano. Tradução do grego, introdução e notas (Coimbra, CECH, 2010).

17. Glória Onelley e Ana Lúcia Curado: Apolodoro. Contra Neera. [Demóstenes] 59. Tradução do grego, introdução e notas (Coimbra, CECH, 2011).

18. Rodolfo Lopes: Platão. Timeu-Critías. Tradução do grego, introduçáo e notas (Coimbra, CECH, 2011).

19. Pedro Ribeiro Martins: Pseudo-Xenofonte. A Constituição dos Atenienses. Tradução do grego, introdução, notas e índices (Coimbra, CECH, 2011).

20. Delfim F. Leão e José Luís L. Brandão: Plutarco.Vidas de Sólon e Publícola. Tradução do grego, introdução, notas e índices (Coimbra, CECH, 2012).

21. Custódio Magueijo: Luciano de Samósata I. Tradução do grego, introdução e notas (Coimbra, CECH/IUC, 2012).

22. Custódio Magueijo: Luciano de Samósata II. Tradução do grego, introdução e notas (Coimbra, CECH/IUC, 2012).

23. Custódio Magueijo: Luciano de Samósata III. Tradução do grego, introdução e notas (Coimbra, CECH/IUC, 2012). 
24. Custódio Magueijo: Luciano de Samósata IV. Tradução do grego, introdução e notas (Coimbra, CECH/IUC, 2013). 
OBRA PUBLICADA

COM A COORDENAÇÁO

CIENTÍFICA

0
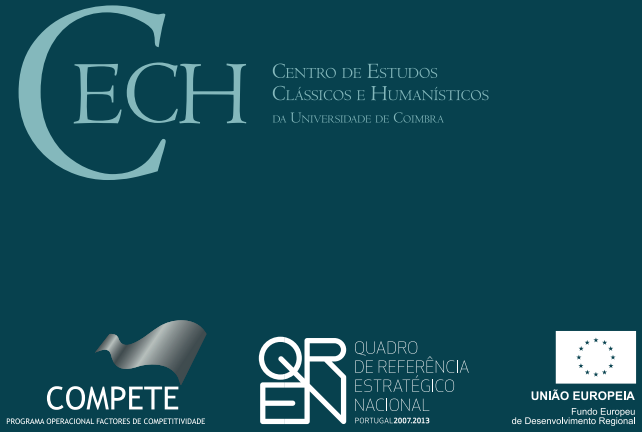